ALBERTO KAPITANGO NGULUVE

\title{
POLÍTICA EDUCACIONAL ANGOLANA (1976-2005): \\ Organização, Desenvolvimento e Perspectivas
}

UNIVERSIDADE DE SÃO PAULO

FACULDADE DE EDUCAÇÃO

SÃO PAULO / 2006 


\section{POLÍTICA EDUCACIONAL ANGOLANA (1976-2005): Organização, Desenvolvimento e Perspectivas}

Dissertação de Mestrado apresentada à Faculdade de Educação da Universidade de São Paulo - FEUSP, como requisito para a obtenção do título de Mestre em Educação. Área de concentração: Filosofia e Educação.

Orientadora: Dra. Cristiane Maria Cornélia Gottschalk.

UNIVERSIDADE DE SÃO PAULO

FACULDADE DE EDUCAÇÃO

SÃO PAULO / 2006 
379.5 (67.3) NGULUVE, Alberto Kapitango

N576P Política Educacional Angolana (1976-2005): Organização, Desenvolvimento e Perspectivas / Alberto Kapitango Nguluve. São Paulo, SP: s.n., 2006.

218p. + anexos; tab.

Dissertação (Mestrado) - Faculdade de Educação da Universidade de São Paulo

1. Política educacional (1976-2005; Angola) 2. Reforma de ensino (Angola) 3. Formação de professores (Angola) 4. Direito à educação (Angola) I. Gottschalk, Cristiane Maria Cornélia, orient

Ficha catalográfica elaborada pelo Serviço de Biblioteca e Documentação da FEUSP. 
Nome do Autor: Alberto Kapitango Nguluve

Título da Dissertação: Política Educacional Angolana (1975-2005): Organização, Desenvolvimento e Perspectivas

Presidente da Banca: Prof ${ }^{a}$. Dra. Cristiane Maria Cornélia Gottschalk / Instit: FEUSP Assinatura:

Banca Examinadora:

Prof. Dr. António Joaquim Severino / Instituição: FEUSP

Assinatura:

Prof. Dr. Luiz Bezerra Neto / Instituição: UFSCar Assinatura:

Aprovada em:

I 


\section{DEDICATÓRIA}

Em memória do pai Albino Nguluve,

À mãe Bernadete Ndjivala, Ao irmão Frederico Chitali Nguluve e

À Laura Eugênia Simão da Costa

pelo contínuo estímulo à carreira acadêmica. 


\section{AGRADECIMENTOS}

À Professora Orientadora Dra. Cristiane Maria Cornélia Gottschalk (FEUSP), que durante dois anos acompanhou o desenvolvimento deste trabalho através de leituras, críticas e contribuições que permitiram o seu melhor direcionamento.

À banca, composta pelos professores Dr. Antônio Joaquim Severino (FEUSP) e Dr. Luiz Bezerra Neto (UFSCar), pelas contribuições, críticas e sugestões, dadas na qualificação, que permitiram uma boa organização do trabalho, maior embasamento teórico, análise e compreensão das questões atinentes ao ensino.

Ao $\mathrm{CNPq}$, pela bolsa concedida, permitindo alargar a busca de dados e material indispensáveis à pesquisa realizada.

A todos que, direta ou indiretamente, contribuíram para que este trabalho viesse à luz,

Meus agradecimentos 


\section{RESUMO}

NGULUVE, Alberto Kapitango: "Política Educacional Angolana (1976-2005): Organização, Desenvolvimento e Perspectivas”. São Paulo. FEUSP, 2006.

Este estudo, bibliográfico e documental, propõe-se a uma reflexão e análise do sistema educacional angolano, desde 1975 a 2005, a partir de uma perspectiva filosófica e política. Com ele pretende-se buscar elementos que permitam compreender as relações e os fatores em torno dos quais se organizou e se desenvolveu a política educacional de Angola; e procura-se analisar as novas perspectivas políticas de reforma do sistema educacional propostas a partir de 2001 (Lei $\mathrm{n}^{\circ}$. 13/01). O trabalho aponta a importância de efetuar-se uma análise dos fatores que determinaram a escolha e as formas de organização do sistema de ensino e sua abrangência nacional. Parte da idéia de que verdades até então incontestáveis não são mais adequadas para justificar os índices elevados de analfabetismo, a não garantia do direito à educação, a falta de acesso e a continuidade de crianças nas escolas, as condições precárias de infra-estrutura educacional, bem como a visão pedagógica que ainda persiste, não obstante o término da guerra (Fevereiro de 2002). Trata-se de uma pesquisa fundamentada em fontes bibliográficas de diferentes autores e documentos oficiais (leis) do ensino angolano e outros documentos pertinentes. $\mathrm{O}$ trabalho termina apontando a necessidade de o Estado priorizar um investimento maior para o setor educacional, assim como, para a formação de professores. Aponta ainda a democracia, a liberdade e a autonomia no trabalho educacional como condições fundamentais ao desenvolvimento do ensino e pesquisa.

Unitermos: Política educacional, Reforma de Ensino, Formação de Professor, Direito à educação.

Linha de pesquisa: Filosofia e Educação.

Banca examinadora: Orientador: Dra. Cristiane Maria Cornélia Gottschalk

Examinadores: Dr. António Joaquim Severino (FEUSP).

Dr. Luiz Bezerra Neto (UFSCar).

Data da qualificação: 11 de Agosto de 2006

Data da defesa: 13 de Dezembro de 2006.

Alberto Kapitango Nguluve (1976): é natural de Angola - província de Huambo. Licenciado em Pedagogia, com especialização em Administração e Supervisão Escolar pela UNISAL de São Paulo/ Brasil (2004). E-mail: ndjevelele@ hotmail.com 


\section{ABSTRACT}

NGULUVE, Alberto Kapitango: "Educational Politics in Angola (1976-2005): Organization, Development and Perspectives”. São Paulo. FEUSP, 2006.

This bibliographical and documental study aims to reflect about and analyze the educational system in Angola from 1975 to 2005, keeping a philosophical and political view. Its purpose is to bring out elements that will help to understand the relations and factors around which have been organized and developed the educational politics in Angola. Furthermore there is an evaluation of the new political perspectives proposed since 2001 in order to change this educational system (Act 13/01). This dissertation explains how important it is to make a good evaluation of the factors that determined the options and models of educational system organization and its national scope. The starting point is the idea that some truths, until now considered unquestionable, are not appropriate to justify the high levels of illiteracy, the non-guarantee of education to all the Angolan population, the faulty access to education, and the students evasion, the poor conditions of educational facilities, as well as the pedagogical vision still remaining after the war (February, 2002). The research was based in bibliographical resources from different authors, official documents (Acts) about Angolan education system, and other documents. At the end this work shows that the government has firstly to invest more in the educational sector, as well as in the teachers' background. The final conclusion is that democracy, liberty and freedom in the educational system are basic conditions to develop the teaching and researching fields.

Keywords: Educational politics, Educational reform, Teachers' background, Educational rights.

Research field: Philosophy and Education.

Examining Professors: Advisor: Dra. Cristiane Maria Cornélia Gottschalk

Examining Professors: Dr. António Joaquim Severino (FEUSP).

Dr. Luiz Bezerra Neto (UFSCar).

First exame: 11 August 2006.

Defence date: 13 December 2006.

Alberto Kapitango Nguluve (1976): was born in Angola - Huambo district. Graduated Pedagogy and specialized in Administration and Educatinal Supervision at UNISAL de São Paulo/ Brasil (2004). E-mail: ndjevelele@hotmail.com 


\section{SUMÁRIO}

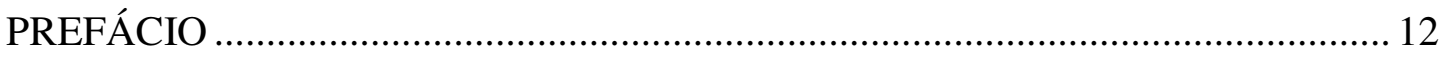

INTRODUÇÃ

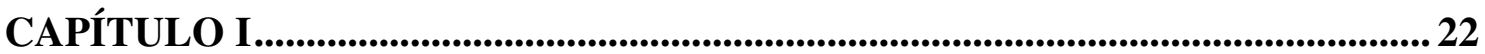

CONTEXTO HISTÓRICO, ECONÔMICO E SOCIOPOLÍTICO DE ANGOLA..... 22

1 - A sociedade angolana: história, política e economia....................................... 22

2 - Luta política, acordos de paz e a continuidade da guerra depois da

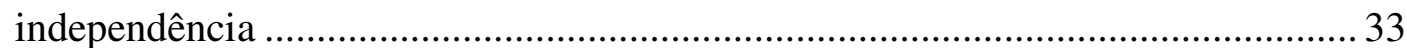

3 - Recrutamento de adolescentes-soldados durante a guerra ............................. 43

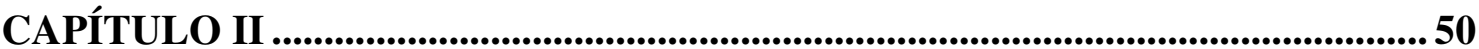

A PRÁXIS EDUCACIONAL EM UM CONTEXTO DE INSTABILIDADE SOCIAL

E POLÍTICA E DE LUTA PELO PODER …............................................................. 50

1 - Formação e atuação de professores nas escolas ................................................5 51

2 - Relações de poder disseminadas no meio educacional .....................................59

3 - Autonomia, liberdade e ordem no sistema educacional ..................................68

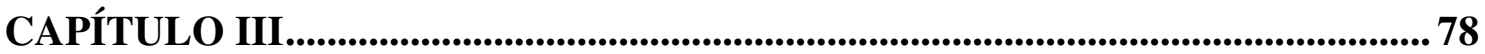

PRIMEIRA REFORMA DO SISTEMA EDUCACIONAL (1976-2000):

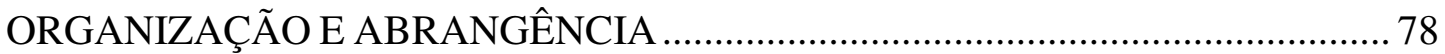

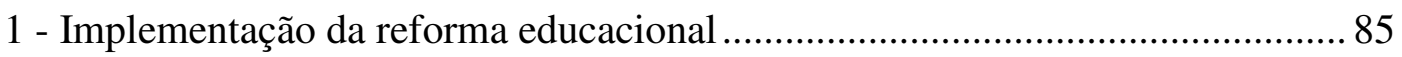

2 - Organização do sistema educacional ............................................................ 88

3 - Abrangência do sistema educacional.............................................................. 91

3.1. Educação pré-escolar e iniciação ............................................................... 91

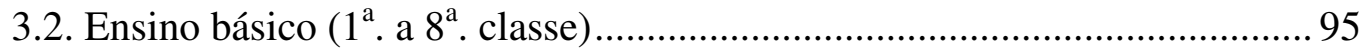

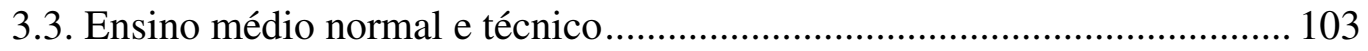

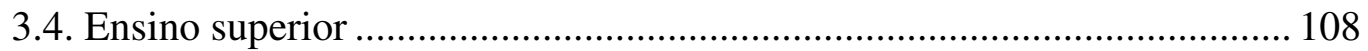

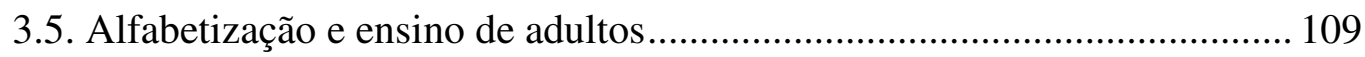


SEGUNDA REFORMA DO SISTEMA EDUCACIONAL (LEI N ${ }^{\mathrm{O}}$. 13/2001):

DESENVOLVIMENTO E PERSPECTIVAS

1 - Da concepção da necessidade da reforma educacional ................................. 114

2 - Reforma e investimento financeiro em educação.......................................... 116

3 - Definição e objetivos do novo sistema educacional ....................................... 124

4 - Organizaçãa do novo Sistema de Ensino ....................................................... 126

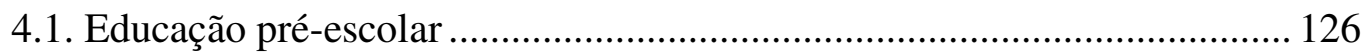

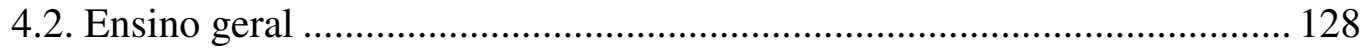



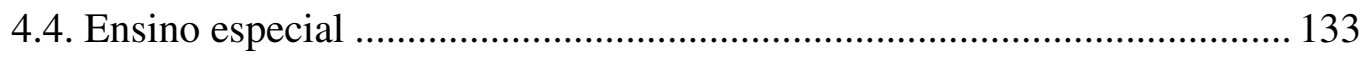

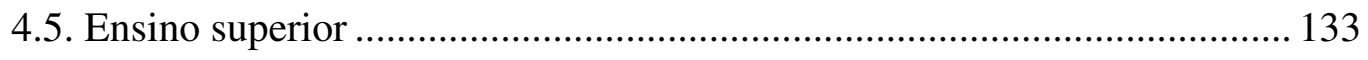

5 - Etapas e critérios de implementação da reforma educacional ......................... 134

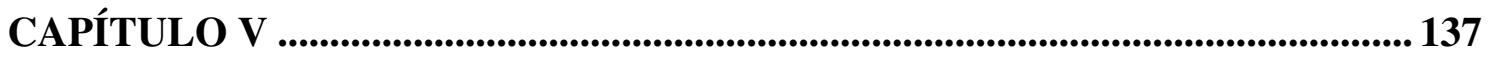

DESENVOLVIMENTO POLÍTICO-ECONÔMICO E A GARANTIA DO DIREITO

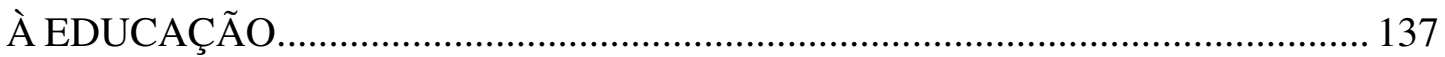

1 - Depois do "socialismo": o papel da educação na produção e reprodução do

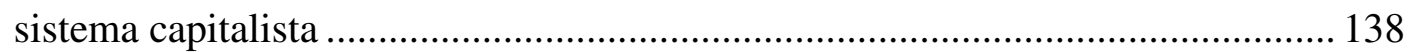

2 - Desenvolvimento econômico e a eficácia educacional ................................... 150

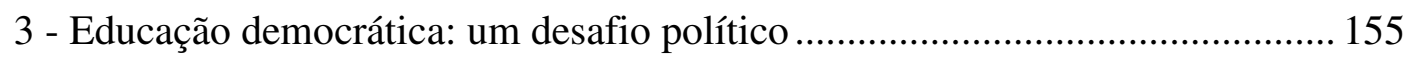

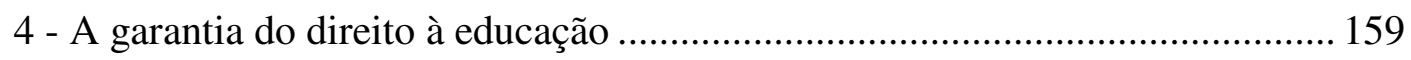

5 - A defesa da dignidade humana pela educação ............................................. 165

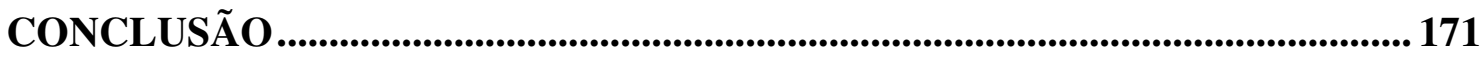

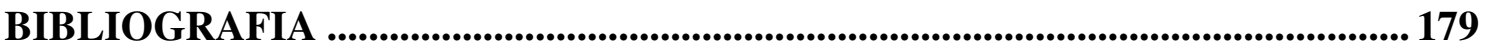



ANEXO 1: LEI DE BASE DO SISTEMA DE EDUCAÇÃO N ${ }^{\circ} .13 / 01$ DE 31 DE

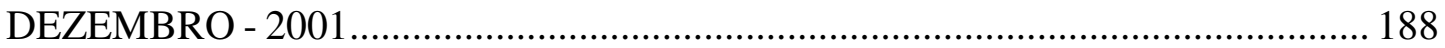

ANEXO 2: PROGRAMA MÍNIMO DO MPLA .................................................... 210

ANEXO 3: PROGRAMA MAIOR DO MPLA …................................................. 211

ANEXO 4: MAPA DE ANGOLA - DIVISÃO ADMINISTRATIVA...................... 218 


\section{ÍNDICE DE TABELAS}

Tabela 1: Financiamento aos partidos com assento no parlamento (2004 e 2006) ------28

Tabela 2: Distribuição das verbas pelas províncias 2004 e $2006------------------------29$

Tabela 3: Taxa de crescimento anual do PIB Angolano (2000-2006) -------------------30

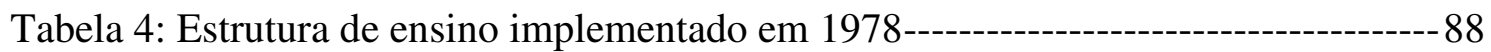

Tabela 5: Freqüência dos alunos na iniciação (1990-1998) ----------------------------95

Tabela 6: Taxa de escolarização primária e de sobrevivência escolar ----------------------98

Tabela 7: Abrangência do ensino básico nas províncias-----------------------------------99

Tabela 8: Tendência de evolução de 1990 a 1998 --------------------------------------- 100

Tabela 9: Freqüência geral de alunos (1997-1998) ------------------------------------- 101

Tabela 10: Alunos matriculados no II ${ }^{0}$. Nível em 1997/8 -------------------------- 102

Tabela 11: Taxa bruta de escolarização por províncias (1997/8)------------------------- 102

Tabela 12: Alunos matriculados por cursos no ensino médio 1990-1998--------------- 105

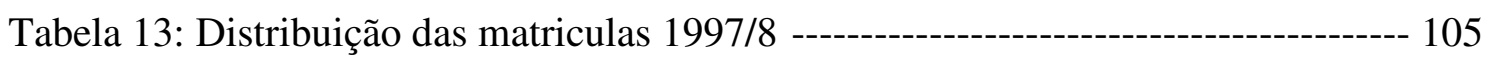

Tabela 14: Alunos do ensino médio normal por províncias ------------------------------- 107

Tabela 15: Ensino superior 1997/8 (divisão por sexo) ------------------------------------ 108

Tabela 16: Resumo das despesas por função, de 2003 a 2006 (\%)---------------------- 120

Tabela 17: Distribuição das despesas nas áreas de educação, 2003 a 2006 ------------- 121

Tabela 18: Despesa por função e programa para a educação, 2003 ---------------------- 121

Tabela 19: Despesa por função e programa para a educação, 2004---------------------- 122

Tabela 20: Orçamento aprovado para as despesas da educação, 2006 ----------------- 123 


\section{PREFÁCIO}

$\mathrm{Na}$ realização de uma pesquisa científica há, basicamente, duas dimensões (desafios) que se apresentam ao pesquisador desde o momento da escolha de seu objeto de estudo: a objetividade e a subjetividade. A pesquisa tem um sentido objetivo na medida em que obedece a uma racionalidade assente na originalidade dos argumentos e problemas abordados seguindo um método. Há, por outro lado, a dimensão subjetiva, a do envolvimento do pesquisador com o seu objeto de estudo, sempre revestido de uma "objetividade".

O pesquisador é impulsionado pelo desejo de saber, de compreender e explicar a gênese e a "verdade" do objeto ou fato em estudo. A verdade racional (razão) é entendida aqui como aquela verdade que resulta de uma organização lógica do pensamento sobre os fatos, sobre a realidade do passado e presente; e a verdade de fato (histórica) como aquela que vê as coisas como são em si mesmas, independentemente da concepção (política, ideológica, filosófica, etc.) construída sobre ela. Nossa organização de mundo leva-nos a construir o conhecimento não só como forma de responder ao problema prático (finalidade prática), mas também como fim em si mesmo. O conhecimento que tem nele mesmo o fim último impulsiona o homem (pesquisador) a querer saber sempre mais, sobre si mesmo, sua história e trajetória, sem perder de vista a necessidade de responder às situações práticas de sua vida política, social, econômica e cultural.

A formulação e determinação de uma verdade ${ }^{1}$ (verdade única) é o fim da própria verdade ${ }^{2}$. É eliminar o desejo, no homem, de querer conhecer e entender a verdade das coisas. É tirar do homem a possibilidade de reformular seu pensamento, seu conceito sobre si mesmo e sobre as coisas. As lucubrações que ora apresentamos são frutos do desejo de compreender a complexa trajetória política da educação de que somos frutos.

\footnotetext{
${ }^{1}$ Formulada em detrimento das demais verdades (interpretações, análises exaustivas da verdade). Esta é tipicamente uma verdade de cunho ideológico-político e repressão.

${ }^{2}$ Não estamos com isso defendendo um excessivo relativismo, mas sim a possibilidade de outras formas de percepção, as várias possibilidades racionais de entendimento coerente.
} 
A reflexão, leitura, análise bibliográfica e documental que trata de Angola e, mais especificamente, da política educacional, da qual resultou a presente dissertação, representa também o percurso do pesquisador (indivíduo) impulsionado pelo desejo de saber, compreender e explicar as controvérsias de um longo processo político educacional. Desejo cativado também pelo descontentamento ou insatisfação diante do pensamento e das justificativas construídas ao longo das últimas três décadas como verdade explicativa da razão de ser do estado da política educacional angolana.

Escrever sobre um processo do qual somos fruto é desafiador, pois, em muitos momentos somos tentados a tomar posições "ideológicas" que nos distanciam da "objetividade científica". Dificuldade essa encontrada também em alguns estudos que tratam da política de Angola, assim como naqueles que tratam da história da educação, do processo da guerra contra o colonialismo (1961 a 1974) e entre os partidos (1976 a 2002) e das justificativas, construídas em torno da guerra. O que mostra a necessidade premente de reanalisarmos o discurso construído para explicar Angola. Isso requer maior envolvimento de pedagogos, filósofos, cientistas sociais, historiadores angolanos nas discussões e na leitura crítica da realidade presente e futura.

A realidade presente, em constante mutação, marcada por discursos e projetos ainda na fase embrionária, parece não nos permitir deter-nos em uma única resposta como "verdade única" em detrimento de outras possibilidades de construção do saber, mas procurar antes compreender as especificidades que o processo dinâmico angolano nos apresenta neste momento e tentarmos, com isso, perceber o seu curso.

Na presente dissertação, não procuramos nos deter no pensamento de um autor, uma vez que não é nossa pretensão fazermos um estudo de educação angolana segundo este ou aquele autor. No trabalho os autores lidos (bibliografia usada) aparecem na medida em que nos ajudam a esclarecer e fundamentar teoricamente a situação-problema em estudo sem perder de vista o objetivo a que nos propomos: analisar como foi organizada a política educacional angolana, sua abrangência, reformas e perspectivas atuais. Conforme aparece na bibliografia deste trabalho existem teses, defendidas na área de história e educação, que procuram mostrar também como se deu o percurso da educação angolana e outros trabalhos, de política e sociologia, que também permitem compreender a trajetória da guerra e sua influência no sistema educacional.

\footnotetext{
${ }^{3}$ Diferente das ciências exatas (ou empíricas) nas quais se procuram as causas de determinado fenômeno observado, nas ciências humanas se procuram explicações relativas aos sentidos do objeto de estudo.
} 


\section{INTRODUÇÃOO}

Neste estudo "Política Educacional Angolana (1976-2005)" nosso intento é tratar das questões da organização do processo educacional, do seu desenvolvimento e abrangência, das reformas e perspectivas, bem como analisar as relações de luta pelo poder político disseminadas no espaço educacional e de manutenção (ou imposição) de uma ordem política que desde finais da década de sessenta se baseava, entre os partidos, na negação do outro no poder, o que fez com que surgisse uma elite intolerante ${ }^{4}$. A construção do discurso que perpassava todas as esferas políticas e educacionais, para legitimar os mecanismos de perpetuação do poder dominante, deu-se visando a implantação e defesa do regime de Partido Único, depois de 1975 pelo MPLA, e com isso garantir sua permanência no poder.

A análise do contexto histórico-político do sistema educacional e das reformas de programas e currículos escolares que estão sendo feitas desde 2001, segundo a LBSE n ${ }^{\circ}$. 13/01 (Lei de Base do Sistema de Educação), sob uma perspectiva política de democracia e garantia do direito à educação torna-se ainda mais complexa quando confrontada ou relacionada com o processo de luta pelo poder em Angola. E para analisar-se todo o processo educacional é necessário não desconsiderar a complexa guerra angolana desencadeada logo depois que de obteve a independência, assim como a ideologia que impulsionou a guerra, uma vez que esta intervém diretamente no andamento do sistema de ensino assim como na estruturação dos programas escolares. Entendemos que uma reformulação eficaz, no atual sistema educacional, precisa ter em conta a inovação da formação de professores, da gestão educacional, do sistema curricular, dos recursos materiais, das infra-estruturas, entre outros e levar a sociedade a exigir maior eficácia (da parte do Estado) na materialização das perspectivas de educação para todos.

\footnotetext{
${ }^{4}$ Também trata desta questão de intolerância entre os movimentos André de Oliveira J. Sango (2002) em sua tese de doutorado, na qual afirma que, devido à ausência de sindicatos e outras organizações sociais com uma força capaz de conter as guerras entre os movimentos durante o longo período colonial, produziu-se em "Angola uma elite intolerante que não mede meios para impor a sua vontade e livrar-se de seus principais opositores" (2002, p. 21).
} 
A exigência de estratégias educacionais, no trabalho administrativo de ensino, e sua materialização (por exemplo, o "Plano Nacional de Educação para Todos" ${ }^{\prime 5}$ ) requerem hoje responsabilidade política por parte dos dirigentes, pois se, por um lado, justifica-se o mau estado educacional de Angola pela colonização, intervenção externa, destruição das suas infra-estruturas e pela guerra que se desencadeou de 1976 a 2002, por outro lado, são gritantes

as graves falhas de quem devia concretizar o projecto de independência e evitar a conseqüente adulteração da situação com a corrupção quase generalizada, a incompetência, a falta de sensibilidade para os verdadeiros problemas, as lutas de capela pelo poder, a timidez na crítica frontal para equacionar os erros, etc. (Pepetela, in: Brittain, 1999, p. 11).

Percebemos que a nova conjuntura política e sócio-econômica em que o país se encontra apresenta uma necessidade premente de solução dos problemas fundamentais nas áreas de educação, de saúde e de saneamento básico, como também de superação do silenciamento ${ }^{6}$ dos problemas de violência contra a dignidade humana. Todavia, é preciso não desconsiderar o entendimento do processo de que resultam estes problemas, isto é, saber que estes são também frutos das relações políticas e sociais construídas durante a guerra (1976-2002), das intervenções externas geradas, em parte, pelas disputas ideológicas da guerra fria em defesa dos interesses da minoria, o que inviabilizou, de alguma forma, qualquer tentativa de firmação política por parte dos movimentos nacionais.

Predominou, nesse período a imposição da vontade dos interesses externos $^{7}$, muitas vezes, camuflados sob o falso discurso da defesa da democracia,

\footnotetext{
${ }^{5}$ O Plano Nacional de Educação para Todos está baseado na política traçada a partir do Fórum Mundial de Educação, realizado no mês de Abril de 2000 em Dakar. O Governo angolano participou e comprometeu-se a alcançar os objetivos e metas de educação para todos. Esta proposta faz parte dos objetivos e metas do milênio que, segundo o documento da UNESCO, devem efetivar-se durante os anos de 2001-2015. Trata-se de atender a um aspecto fundamental de melhoria das condições sociais e relacionamento entre as nações. A educação para todos visa também atender à necessidade de maior comunicação entre as pessoas, entendimento das questões sociais, políticas e culturais, etc.

${ }^{6}$ Silenciamento: refere-se ao mecanismo empregue para impedir que situações desumanas, a que várias pessoas foram e são submetidas ainda hoje, não venham à tona. Mantêm-se em silêncio situações contra a dignidade humana quando diante de situações concretas, que exigem respostas concisas do Estado ou do governo local, tomam-se medidas paliativas. Estas nada mais são que uma forma de protelar os problemas sociais vigentes e manter uma imagem camuflada da realidade.

${ }^{7}$ Maiores detalhes a respeito da predominância da vontade externa em Angola podem encontrar-se na obra de Henry Kissinger. Memórias. Vol. III: Anos de revolução, 2001, p. 819-861.
} 
liberdade e paz. Não estão exclusos da responsabilidade os autores nacionais que, através de alianças e apoio recebido dos países externos, não se importaram em sacrificar milhões de vidas inocentes ${ }^{8}$.

Aspecto "interessante" e ao mesmo tempo assustador é notar que, no atual momento, mesmo depois de quase quatro anos (2002-2006) de "paz", isto é, do calar das armas, a destruição da vida social da população ainda continua firme, só que, claro, em novos moldes ou mecanismos: pela ignorância ${ }^{9}$ e pelo silenciamento de problemas que até aqui têm sido vividos. Assim, deixa-se impune a corrupção, a falta de responsabilidade política na administração e no uso de bens públicos, como também se isenta de responsabilidade os verdadeiros autores da guerra, pois, ao final, todos se tornaram "vítimas" do mesmo processo bélico.

Assim, para criar novas justificativas da situação vigente em Angola, não faltou "historiadores", ideólogos e outros interessados em escrever a história que apontassem, segundo Pepetela (1999), o “dedo acusador ao povo, em última análise o eterno culpado de todo o mal que lhe possa acontecer, e incensassem os verdadeiros criminosos. A tragédia estaria definitivamente consumada e historicamente justificada. Seria a Verdade Única” (In: Brittain, 1999, p. 10).

O contexto sócio-político vigente permite-nos levantar a seguinte questão: estamos vivendo uma fase de virada da história ou apenas uma nova forma de reescrever o discurso, de implementar a ordem sem, no entanto, haver mudanças significativas na estrutura educacional, política e administrativa do país, uma vez que o ideal de apropriação do poder político e econômico por uma minoria permanece e, com isso, destitui-se os demais do direito de beneficiarem-se daquilo que o país tem como recursos, que possibilitariam a melhoria das condições de vida social?

\footnotetext{
${ }^{8} \mathrm{O}$ angolano André de Oliveira J. Sango defende, em sua tese de doutorado, a idéia de que, assim como em muitos países africanos, quando em Angola os movimentos de luta de libertação conseguiram chegar à "ascensão da independência pouco ou nada se fez para possibilitar o desenvolvimento do país, dando origem a uma situação bastante difícil para suas populações" (Sango, 2002, p. 17). Igualmente partilha desta idéia o angolano Dr. Manuel Jorge, professor na Universidade da Sorbonne, advogado em Paris, conselheiro econômico para países como Japão e presidente da casa de Angola na França. Segundo este doutor, Angola dispõe de condições econômicas suficientes para que o seu povo tenha "uma sorte diferente da que lhe tem sido dada" (In: Revista. Figuras \& Negócios. Setembro de 2004, p. 8).

${ }^{9}$ A produção da ignorância refere-se ao mecanismo ideológico empregue propositalmente pelo sistema de governo como forma de garantir sua permanência no domínio de poder. Ela é produzida através da descontinuidade do processo educacional e da não garantia por parte do Estado de medidas que levariam, por exemplo, a criança a freqüentar sem interrupção todo o ensino básico. A ignorância (que também pode ser entendida como ausência do saber escolar) em grande medida impede a pessoa de reconhecer-se injustamente governado ou pobre. A ignorância se difunde limitando as pessoas a um determinado mecanismo ideológico, sem espaço para a crítica e efetivação de um ensino de qualidade.
} 
Começa assim nossa preocupação em relação à educação e à forma como foram e são feitas as reformas no sistema educacional. Quais são as reais mudanças que foram e estão sendo feitas de modo a contribuir para a construção de uma Angola melhor? O que realmente permaneceu e o que mudou? A escola não só é instrumento do Estado como também é espaço propício de desenvolvimento de crítica social, política, ideológica, cultural e de construção do saber (teórico e prático) necessário para o entendimento e convivência social.

Ao longo do trabalho, procurar-se-á responder, entre outras, as questões que constituem o objeto fundamental da pesquisa, isto é, como, porquê e de que forma foi organizado e desenvolvido o sistema educacional angolano? Qual foi a abrangência da política educacional, sua eficácia e desafios? Em que medida a reforma do sistema de ensino (Lei $n^{0}$. 13/2001) responde às situações que enfermam o sistema educacional Angolano? De que maneira a educação pode contribuir, hoje, no fortalecimento de uma política democrática, de diálogo, entendimento e convivência social?

A responsabilidade política por um sistema educacional preocupado com o desenvolvimento da cultura de paz, democracia e respeito mútuo significa também responsabilidade pela dignidade do ser humano, isto é, reconhecer que o homem deve ser sempre tratado como um fim em si mesmo e não como meio, tal como acontece na luta pelo poder, através da guerra, justificada por um discurso de "defesa nacional". A cidadania passa pela formação plena e garantia dos direitos fundamentais, o que requer uma atitude filosófica e política de crítica constante, visando tornar inteligível a práxis educativa no espaço escolar.

Depois de trinta anos da independência parece-nos certo afirmar que a justificativa de muitos políticos, forjada na mente das pessoas durante a guerra, não se sustenta, quando intentamos refletir acerca dos problemas reais que enfermam o sistema educacional angolano. A classe dirigente trata o "fenômeno" da guerra como algo que tem vida própria, como um "fenômeno" externo e alheio à vontade de todos. Ora, a guerra não é nenhuma instituição que paira sobre a vida dos angolanos, pelo contrário, ela resulta do fato de um determinado grupo pretender apropriar-se do monopólio do poder $^{10}$ e fazer da luta política espaço de defesa de seus interesses econômicos. Há uma

\footnotetext{
${ }^{10}$ Ao falarmos em monopolização do poder queremos apontar para a concepção do poder enquanto mecanismo que leva um homem ou grupo a tirar vantagens em relação aos outros em beneficio próprio.
} 
outra dimensão da guerra que, também, não pode ser desconsiderada, que é o fato de uma guerra desestruturar completamente a vida das pessoas, destruir referências, alterar estruturas psíquicas e com isso gerar um grande desequilíbrio social e econômico.

É importante compreender os aspectos da guerra ${ }^{11}$ desencadeada em Angola depois de 1975 uma vez que o país atual tem milhares de pessoas, fundamentalmente marcadas por uma experiência de guerra muito recente. $\mathrm{O}$ desafio do estudo da política educacional angolana consiste também em esclarecer a dupla perversão construída em torno da guerra, isto é, mostrar por um lado, a dimensão política do discurso de guerra e, por outro lado, a trajetória ou percurso de luta em busca do poder no país. Percebe-se que as mesmas pessoas responsáveis pelo estado de guerra ontem, hoje assumem a condição de vítimas, não respondendo pela responsabilidade política ou pelas conseqüências que resultaram desta guerra. Em outras palavras, todas as calamidades são explicadas pela guerra, mas a guerra quem explica? O presente trabalho encontra, desta forma, sua importância naqueles que, através da escola e da educação, pretendem alargar o entendimento destas questões, pautando-se pela liberdade e autonomia intelectual.

O desenvolvimento da democracia requer o fim da educação que procura promover uns em detrimento de outros, que estabelece uma oligarquia por condições econômicas que cada pessoa dispõe. Se acreditarmos que as condições econômicas devem constituir parâmetro para determinar o acesso ao ensino estaremos nos contradizendo, uma vez que, nos princípios da educação angolana, desde o início da

Ou seja, a forma do homem procurar ter em sua posse todos os meios que possam satisfazer suas necessidades (fora do normal aceitável) em prejuízo a outras pessoas, colocar os bens ao seu belo prazer ou à sua dependência (corrupção / cooptação).

11 Conforme demonstra André de Oliveira J. Sango em sua tese de doutorado defendida na Universidade de São Paulo - Faculdade de filosofia, Letras e Ciências Humanas - em 2002, a guerra que se desencadeou em Angola a partir de 1975 "surpreendeu muitos, foi um choque para outros e a expressão da vontade daqueles que acreditavam que a única forma de chegar ao poder seria afastar os demais concorrentes por via da violência" (2002, p. 7). A existência de três movimentos políticos poderia permitir que fosse instalado um sistema político democrático, bastando, em princípio, transformar os três movimentos em partidos políticos. Conforme será abordado no primeiro capítulo, no ponto dois, que trata da luta política e dos acordos de paz, o Acordo do Alvor, que tratava do Governo de Transição previa, em seu estatuto, a participação dos três movimentos na administração de Angola, assim como de implementar-se um sistema político democrático - alternância nos cargos administrativos através de eleições periódicas. Antes da independência, a O.U.A. (Organização da Unidade Africana) aconselhava os três movimentos a criarem uma frente (organização) que permitisse a existência de um "fórum de concertação em que os líderes poderiam discutir as questões do futuro" (Sango, 2002, p. 8) de Angola depois da independência. Os movimentos continuaram a combaterem-se entre si, permaneceu o desentendimento, e a criação de zonas exclusivas para os combatentes de cada movimento facilitou a efetivação da guerra depois da proclamação, a 11 de novembro de 1975, da independência angolana. 
independência, constam a gratuidade e a igualdade para todos como aspectos fundamentais no acesso à escola (primeiro nível).

De acordo com a constituição, a "educação é um direito de todo cidadão", portanto, não é um favor que o Estado presta à sociedade. Como dizia Arendt (2000, p. 235) é preciso que aqueles que fazem a educação assumam "na educação a responsabilidade, ao mesmo tempo, pela vida e desenvolvimento da criança e pela continuidade do mundo". Assim sendo, postula Arendt (2000, p. 239), "qualquer pessoa que se recuse a assumir a responsabilidade coletiva pelo mundo não deveria ter crianças, e é preciso proibi-la de tomar parte em sua educação". O mesmo vale para aqueles que assumem os cargos administrativos e governamentais sem, no entanto, observarem as devidas responsabilidades políticas e públicas que tais cargos exigem.

Para haver revolução cultural e firmar-se uma identidade da nação é preciso um ambiente em que as leis sobre a liberdade, direitos e deveres sejam observadas. Com isso a educação preocupada em despertar a mente para a crítica, compreensão e entendimento do meio social pode oferecer condições teóricas para a superação de problemas sociais. Mas antes há que compreendermos: qual educação, quais objetivos, que tipo de homem se pretendia formar para esta sociedade. Isto é fundamental no delineamento da nova política educacional angolana, pois evita percorrer caminhos que, no passado, não permitiram chegar a um desenvolvimento humano mais equilibrado.

A necessidade de defesa e melhoria do sistema educacional fundamenta-se no fato de que "na educação e por ela, o homem não somente assume uma condição de abertura ao novo, mas, sobretudo, supera a si mesmo, atualiza suas capacidades e potencialidades" (Platão In: Teixera, 1999, p. 24). Assim sendo, afirma Platão a "tarefa primeira da educação é a humanização. Educar um homem implica ajudá-lo a tornar-se humano" ( $i b$, p. 25$)$. Pela educação, o homem consegue propor e conservar a sua forma de existência social e política por meio da vontade própria e da razão, isto porque, a educação

participa na vida e no crescimento da sociedade, tanto no seu destino exterior como na sua estruturação interna e desenvolvimento espiritual; e, uma vez que o desenvolvimento social depende da consciência dos valores que regem a vida humana, a história da educação está essencialmente condicionada pela transformação dos valores válidos para cada sociedade. À estabilidade das 
normas válidas corresponde à solidez dos fundamentos da educação. Da dissolução e destruição das normas advém a debilidade, a falta de segurança e até a impossibilidade absoluta de qualquer ação educativa (Jaeger, 2003, p. 4).

Em suma, entendemos que a concepção de uma nova estrutura de ensino e a implementação de novas medidas com vistas a sanar os problemas que a educação angolana enfrenta passa pela reforma administrativa e pela implementação de uma política de ensino preocupada com a emancipação humana e valorização de sua cultura.

A idéia de analisar e refletir sobre a política educacional da sociedade angolana é realmente desafiadora. A paz que Angola está vivendo é resultado de um processo complexo e, de uma forma ou de outra, o país está marcado por este processo complexo de guerra que influencia a estruturação das novas perspectivas de educação comprometida com a justiça social no país. Como dizia Jorge (1998, p. 87), "para compreender o drama político angolano, é preciso conhecer o teatro onde as cenas se desenrolaram, o seu cenário e os seus principais actores", as relações de luta política pelo poder e os mecanismos usados para legitimar o discurso desta luta.

O trabalho que hora apresentamos encontra-se organizado da seguinte maneira:

a) Primeiro Capítulo: Contexto Histórico, Econômico e Sociopolítico de Angola: apresenta, de forma geral, o contexto político, social e os aspectos econômicos de Angola. Trata também dos acordos realizados desde a independência até 2002 e da incorporação "obrigatória" de adolescentes-soldados à vida militar, durante a guerra.

b) Segundo Capítulo: A práxis Educacional em um Contexto de Instabilidade Social e Política e de Luta pelo Poder: trata da formação e atuação de professores no ensino e da prática educativa de professores durante o período em estudo. Aponta a importância do papel dos professores na sociedade, da sua autonomia e liberdade no desenvolvimento do trabalho de ensino e analisa as repercussões da guerra no processo educacional, assim como do discurso construído em torno da guerra. 
c) Terceiro Capítulo: Primeira Reforma do Sistema Educacional (1976-2000): Organização e Abrangência: analisa a organização e aplicação do sistema de ensino vigente no período de 1976 a 2000, a abrangência desta política de ensino, a complexidade sociocultural que o país apresentava e o desafio que tal complexidade demandava para o ensino, que se via impedido por uma situação de guerra e pouca infra-estrutura.

d) Quarto Capítulo: Segunda Reforma do Sistema Educacional (Lei $n^{o}$. 13/01): Desenvolvimento e Perspectivas: Apresenta como está sendo realizada a reforma do sistema educacional, as etapas de implementação, a forma como está organizado, assim como os objetivos que este sistema estabelece para cada nível de ensino.

\section{e) Quinto Capítulo: Desenvolvimento Político-Econômico e a} Garantia do Direito à Educação: analisa o papel da educação na construção social, a importância e necessidade da garantia do direito à educação como condição fundamental ao desenvolvimento social e econômico numa sociedade democrática. Neste capítulo procura-se defender a idéia de que o crescimento econômico não deve desligar-se do desenvolvimento humano e a de que é fundamental que se criem mecanismos políticos que permitam estabelecer uma relação entre o crescimento econômico e o desenvolvimento educacional como condição para a melhoria da vida social.

f) Conclusão: apresenta algumas reflexões, a partir do que foi abordado nos cinco capítulos, apontando a necessidade de uma maior atenção do Estado ao sistema educacional, maior investimento na formação de professores, redefinição do papel educacional visando maior articulação das questões sociais e da importância do direito à educação tanto para a vida das pessoas como para a melhoria das condições políticas e administrativas de Angola. 


\section{CAPÍTULO I}

\section{CONTEXTO HISTÓRICO, ECONÔMICO E SOCIOPOLÍTICO DE ANGOLA}

\section{1 - A sociedade angolana: história, política e economia}

A realização de uma análise pormenorizada do contexto histórico, econômico, sociopolítico e cultural de Angola requer, necessariamente, distinguir os aspectos de organização político-cultural e educacional anteriores à presença portuguesa (1482-1575) das concepções político-culturais construídos durante a colonização portuguesa (século XIX e primeira metade do século XX), e com isso podermos compreender de que resulta a trajetória político-educacional de 1975 até a data presente (2006), ou seja, para compreender o que é Angola hoje. Tal análise não só é indispensável à sociedade do presente como também é fundamental para a construção, solidificação e unidade político-cultural de Angola ${ }^{12}$.

A compreensão do que é Angola hoje passa, entre outros, pela compreensão daquilo de que foi feito sua história, sua educação e sua cultura e pela compreensão do tipo de política de colonização (mentalidade) empreendida durante os últimos dois séculos da presença portuguesa em Angola. Compreendemos que se trata de uma trajetória complexa, feita de ideologia fundamentada nos mais diversos princípios, desde a idéia de civilizar e expandir o cristianismo à idéia de uso da força para a tomada do poder, de desvalorizar, de caracterizar e impor uma ordem de pensamento, uma forma de entender as coisas e uma forma de compreender-se.

Um estudo histórico, político e sociocultural dessa dimensão levarnos-ia a distinguir e compreender melhor sobre quais princípios políticos e culturais estava baseada a educação (formação) e a vida do homem angolano (e em geral da

\footnotetext{
${ }^{12}$ Falamos em unidade cultural, pois a Angola que conhecemos hoje, suas divisões administrativas, territoriais e geográficas, resultam da divisão feita pelas potências colonizadoras segundo seus interesses e áreas de domínio. O estabelecimento dessas fronteiras, traçadas de acordo com as conveniências coloniais, não teve em conta o mapa geopolítico e cultural dos povos nativos, o que levou a ter no mesmo país, como Angola, a presença de culturas lingüísticas diferentes.
} 
África negra) antes da colonização e os princípios em que hoje, depois da colonização, se baseiam sua educação e formação. Embora não seja nosso objetivo escrever sobre a história geral da educação angolana e sim sobre a política educacional depois da independência (1976-2005) e suas perspectivas na atualidade, não está ausente, em nós, a necessidade e a preocupação de compreender a força do pensamento construído durante a colonização, arraigado ainda hoje na política educacional angolana, mesmo depois de alcançada a independência.

Compreender o que é Angola hoje passa também pela análise da complexidade cultural de que é feita Angola e pela percepção das dificuldades que obstam pesquisadores e escritores quando se trata de distinguir o que é fruto da colonização e o que é realmente cultural, na tradição angolana, de distinguir as formas de conceber o homem e seu meio social na cultura angolana e na forma ou visão européia imposta e construída, sobretudo, a partir dos séculos XIX e XX da nossa era.

Foram alcançadas as independências africanas, mas a visão construída sob um prisma dominador permanece. Para se defender a dignidade da mulher e do homem angolano recorre-se hoje aos princípios e leis de direitos humanos, com um olhar europeu ou ocidental, abdicando-se dos princípios culturais próprios (fruto do processo de assimilação), sobre os quais assentava a formação bantu ${ }^{13}$ : a formação de um homem digno de si mesmo, integral (cultural e politicamente) em sua comunidade. Formação essa que punha o ser humano em sua plenitude na comunidade tradicional como o fundamento de toda a ação e razão explicativa da vivência (convivência) em comunidade.

$\mathrm{Na}$ luta pelas independências, os pioneiros africanos sobrepujaram um complexo geopolítico com um desafio maior comparado ao das nações da Europa e das Américas, uma vez que estas dispunham, minimamente, de uma unidade lingüística e cultural. Como dizia Kissinger (2001)

\footnotetext{
As nações européias representaram, no cômputo geral, unidades culturais, étnicas e, acima de tudo, lingüísticas, enquanto as nações africanas eram vestígios libertados de colônias que tinham sido entalhadas no continente pelos colonizadores europeus nas lutas uns com os outros. As fronteiras
}

\footnotetext{
${ }^{13}$ Leia-se a obra de Raul Ruiz de Asúa Altuna. Cultura tradicional banto. 1985. Nela o autor analisa os princípios que norteiam a formação e iniciação cultural do homem e da mulher nas comunidades (sociedade) e apresenta uma visão geral do que é cultura bantu, assim como as concepções sobre o divino e sua representatividade na sociedade.
} 
foram traçadas de acordo com a conveniência da administração colonial ou para estabelecer uma versão africana do equilíbrio de poder na Europa. Para desencorajar a resistência unificada e para assegurar que o idioma da potência imperial se tornasse língua franca, as fronteiras, com freqüência, cortavam divisões tribais (Kissinger, 2001, p. 821).

Os líderes de movimentos africanos em suas lutas pela independência não puderam reorganizar o mapa geopolítico africano de forma diferente do que tinha sido traçado pelas potências colonizadoras, se não, agir dentro das dimensões territoriais impostas: criar uma nação com várias culturas e línguas, como é o caso de Angola. Entre arriscar contendas sem fim, que um projeto de reorganização geopolítico e cultural das fronteiras poderia gerar, preferiu-se arriscar construir os países dentro dos limites traçados e herdados dos interesses dominantes. Essa situação não impediu a praticidade de organização de lutas simultâneas contra os colonizadores e contra os seus rivais internos, pretendentes também do poder, uma vez alcançada a independência.

Assim como em outras colônias portuguesas na África, a história das lutas de resistências e de libertação empreendidas por movimentos de Angola e suas ligações com outros movimentos africanos, unidos pelo mesmo objetivo de liberdade, tem raízes mais profundas do que se costuma pensar. As lutas armadas que levaram às independências das colônias portuguesas na África surgiram de diversas maneiras, desde manifestos escritos, de intelectuais africanos que procuravam por várias formas conscientizar as populações, aos "diversos movimentos nativistas, movimentos proféticos, messiânicos, greves, desobediência civil” (Serrano, 1988, p. 125).

Além das manifestações que se davam localmente, havia outras, organizadas por estudantes e emigrantes africanos, que se encontravam em Portugal, através de organizações como a Liga Africana, criada em 1919 e que permitiu aos jovens de diversas colônias reunirem-se pelo mesmo objetivo de luta pela liberdade. A terceira Conferência Pan-Africana, realizada em 1923, em Lisboa, mesmo se limitando dentro dos paramentos legais da colônia, em termos de injustiças sociais, não deixou de permitir aos líderes de movimentos tomarem consciência da situação em que se encontravam e organizarem-se visando uma melhor articulação de suas lutas. Contudo, é depois da segunda Guerra Mundial que a consciência política e nacionalista desses movimentos ganha maior expressão e força na luta pela liberdade e independência. Conforme dizia Serrano (1988) 
Em 1951 surge em Lisboa o Centro de Estudos Africanos, que conta entre os fundadores jovens estudantes que se tornariam alguns dos mais expressivos líderes dos movimentos de libertação nacional. São eles: Amílcar Cabral (Guine-Bissau), Agostinho Neto (Angola), Francisco Tenreiro (um poeta natural de São Tomé e Príncipe, falecido em Portugal em 1963) e Mário Pinto de Andrade (Angola) [...] As autoridades fascistas puseram fim às atividades desse Centro, mas não daqueles estudantes, como de outros que deram continuidade à luta política anticolonial na Casa do Estudante do Império através de uma intensa atividade cultural dos povos (Serrano, 1988, p. 128-129).

A Casa do Estudante foi fechada em 1964, depois do início da luta armada, e com isso os lideres de vários movimentos procuraram dedicar-se às atividades políticas em seus lugares de origem - formação de partidos políticos e lutas pela independência. Em Angola, um dos primeiros movimentos, chamado Partido da Luta Unida (PLUA), foi criado em 1953. Três anos depois os dirigentes da PLUA e de outros movimentos se juntaram com o objetivo de formar um vasto movimento popular de luta pela libertação de Angola. Dessa mistura surgiu o MPLA - Movimento Popular de Libertação de Angola (1956).

Juntamente com a luta anticolonial desenvolvida pelo MPLA havia um outro movimento nacional - a FNLA (Frente Nacional de Libertação de Angola). Um movimento "pró-Ocidente e sobretudo identificado etnicamente com a população bacongo do norte de Angola e a sua diáspora na República do Zaire, introduziu-se em Março de 1962" (Serrano, 2002, p. 142). Durante os anos seguintes de guerra contra o colonialismo, estes movimentos, além de lutarem contra o colonialismo (objetivo primeiro de todos os movimentos), também entravam, algumas vezes, em conflito entre si. E apesar dos esforços da OUA (Organização da Unidade Africana) apelarem pela unidade dos movimentos nacionalistas de luta pela independência, os conflitos entre os movimentos, internamente, continuaram não dando prioridade à unidade.

Da FNLA surgiu em 1966 um outro movimento formado por dissidentes deste, encabeçados por Jonas Savimbi, originário do sul de Angola e outrora encarregado das funções de relações exteriores da FNLA. O movimento formado por Jonas Savimbi iria chamar-se UNITA (União Nacional para a Independência Total de 
Angola). Este movimento se constituiu como uma grande força contra o colonialismo na parte sul e Leste de Angola. A UNITA também era combatida pelo MPLA, e assim como a FNLA, o conflito armado entre estes movimentos subia de patamar à medida que se aproximava a independência. O MPLA, liderado por Agostinho Neto, tinha menor base nas tribos comparado aos outros dois movimentos (UNITA e FNLA), porém "era o mais forte na capital, a cidade de Luanda, e na área do encontro. E como na capital estavam as embaixadas estrangeiras, dando simbolismo importante à corrida pelo reconhecimento internacional, o MPLA levava vantagem" (Kissinger, 2001, p. 822). E com a ajuda maciça de aviões e outros materiais de guerra que o MPLA recebia da União Soviética e Cuba o equilíbrio do poder em Luanda ficou cada vez mais desequilibrado. Esta situação

Cedo se traduziria em ataques do MPLA aos outros membros do governo de transição. As forças de Roberto e de Savimbi seriam expelidas da capital e dos arredores. A vitória na batalha por Luanda resultaria em pleito prima facie pelo reconhecimento internacional (Kissinger, 2001, p. 826).

Durante os catorze anos de luta contra o colonialismo (1961-1974), os movimentos, além de lutar contra o colonialismo, inimigo comum, também procuraram separar-se, passando a ver no outro um segundo inimigo em potencial e que, portanto, "deveria" ser combatido e posto fora do poder. Durante a luta, cada movimento procurou recrutar seus combatentes nos diversos espaços em que a luta era conduzida, assim como mobilizar os indivíduos combatentes dentro e fora do território nacional. Essas lutas e organizações constituíram, mais tarde, o pano de fundo das lutas políticas depois de 1975.

Note-se que a trajetória política dos movimentos de libertação e luta pelas independências africanas começou, de maneira mais efetiva, depois da Segunda Guerra Mundial. E em Angola a luta empreendida de forma conjunta, pela UNITA, MPLA e FNLA, para o fim da colonização começou em 1961 e terminou em 1974. Desde a independência (1975) até a data da revisão constitucional de 1992, o país era 
chamado de República Popular de Angola, sob o governo do MPLA-PT ${ }^{14}$. Desde a revisão constitucional de 1992 Angola passou a chamar-se República de Angola. A lei atualmente em vigor em Angola foi elaborada em 1975, antes da data de 11 de Novembro (dia da independência) do mesmo ano e readaptada depois da data da independência. A constituição foi revista quatro vezes - em 7 de janeiro de 1978, em 11 de agosto de 1980, em 6 de março de 1991 e em 26 de agosto de $1992^{15}$.

A lei em vigor em Angola é baseada na lei civil Portuguesa e no sistema comum de direito europeu. $\mathrm{O}$ que foi feito depois da independência é uma adaptação, alterando-se alguns aspectos que diretamente não se aplicam em Angola. Segundo os dados disponíveis no site do consulado angolano no Brasil, a lei "foi alterado em aspectos fundamentais, na última década do século $\mathrm{XX}$, em termos de direitos constitucionais e econômicos" para permitir a existência do multipartidarismo no país assim como a "liberdade de imprensa e expressão e o desenvolvimento de uma economia de mercado, com garantias de protecção da propriedade privada"16.

No que tange à organização política e administrativa, em Angola foi implantado o sistema de democracia pluripartidária em 1992, e com isso a realização das primeiras eleições democráticas (29 e 30 de setembro). A constituição em vigor estabelece o sistema semi-presidencialista, e o Estado é representado pela Presidência da República, Assembléia Nacional, Governo Nacional com um mandato de 5 anos e os Tribunais.

Os principais partidos políticos (com assento no parlamento) existentes em Angola, reconhecidos desde a implantação do sistema de democracia pluripartidária em 1992, são: MPLA (Movimento Popular de Libertação de Angola), UNITA (União Nacional para a Independência Total de Angola), FNLA (Frente Nacional de Libertação de Angola), PLD (Partido Liberal Democrático), PRS (Partido de Renovação Social), PRD (Partido Renovador Democrático), AD-Coligação, PSD (Partido Social Democrático), PAJOCA (Partido da Aliança da Juventude, Operários e Campesinatos de Angola), PDP/ANA (Partido Democrático para o Progresso/ Aliança

\footnotetext{
14 Até então o MPLA era chamado de Movimento Popular de Libertação de Angola - Partido do Trabalho.

${ }^{15}$ Maiores detalhes podem ser encontrados também no endereço eletrônico do consulado de Angola no Brasil. http://www.consuladodeangola.org/ 13/08/2006 - 01:50' ou em Documentos da independência. Angola: 11 de Novembro de 1975. Luanda, 1975.

${ }^{16} \mathrm{http}: / / w w w . c o n s u l a d o d e a n g o l a . o r g / 13 / 08 / 2006$ - 01:50'
} 
Nacional de Angola), PNDA (Partido Nacional Democrático Angolano). Na tabela abaixo mostramos a distribuição das verbas que o governo nacional destina aos partidos.

Tabela 1: Financiamento aos partidos com assento no parlamento (2004 e 2006)

\begin{tabular}{l|r|r}
\hline \multicolumn{1}{|c|}{ Designação/ Partido } & \multicolumn{1}{c}{$\mathbf{2 0 0 4}$} & \multicolumn{1}{c}{$\mathbf{2 0 0 6}$} \\
\hline MPLA & 54,63 & 54,63 \\
UNITA & 34,66 & 34,66 \\
FNLA & 2,44 & 2,44 \\
PLD & 2,42 & 2,42 \\
PRS & 2,31 & 2,31 \\
PRD & 0,91 & 0,91 \\
AD-Coligação & 0,89 & 0,89 \\
PSD & 0,85 & 0,85 \\
PAJOCA & 0,36 & 0,36 \\
PDP/ANA & 0,27 & 0,27 \\
PNDA & 0,26 & 0,26 \\
\hline Total (\%) & $\mathbf{1 0 0}$ & $\mathbf{1 0 0}$ \\
\hline
\end{tabular}

Fonte: Diário da República de Angola de 30 de dezembro de 2003, p.

2498 e de 30 de dezembro de 2005, p. 3319.

Administrativamente Angola está dividida em dezoito províncias: Cabinda, Zaire, Uige, Luanda, Bengo, Kwanza-Norte, Kwanza-Sul, Malange, LundaNorte, Lunda-Sul, Benguela, Huambo, Bié, Moxico, Namibe, Huíla, Cunene e KwandoKubango (vide o mapa no anexo 4). As línguas faladas em Angola são: Umbundu, Kimbundu, Kikongo, Fiote, Tchokwe, Nganguela Kwanhama e Nhaneka-Humbe. Desde o início da colonização se impôs o português como a língua oficial do país em detrimento das outras línguas. E mesmo depois da independência o português continua, segundo a constituição e a lei da educação, como a língua oficial de Angola. $\mathrm{O}$ art. $9^{\circ}$ da Lei de Bases do Sistema da Educação (LBSE) de 2001 estabelece que o "ensino nas escolas é ministrado em língua portuguesa" (vide o anexo 1).

A administração dos recursos é feita, em grande medida, pelo governo central (estrutura central) e, nas províncias, pelo governo local. Os governos provinciais não são autônomos, dependem diretamente do governo nacional, que concentra todo o poder administrativo. Conforme mostra a Tabela 2, a seguir, das verbas aprovadas no Orçamento Geral do Estado, mais de $75 \%$ ficam sob o poder da estrutura central, enquanto as províncias recebem menos de 2\%, com exceção de Luanda, que em 2004 recebeu 5,87\%. A porcentagem das verbas destinadas às províncias não é fixa, ela varia a cada ano, o mesmo acontece com a educação, saúde e outros setores. 
Tabela 2: Distribuição das verbas pelas províncias 2004 e 2006

\begin{tabular}{l|r|r}
\hline Províncias & $\mathbf{2 0 0 4}$ & $\mathbf{2 0 0 6}$ \\
\hline Bengo & 0,55 & 0,16 \\
Benguela & 1,86 & 0,81 \\
Bié & 0,84 & 0,42 \\
Cabinda & 1,94 & 0,65 \\
Estrutura Central & 77,9 & 91,74 \\
Exterior & 1,49 & 0,53 \\
Huambo & 0,48 & 0,53 \\
Huíla & 1,49 & 0,62 \\
Cuando Cubango & 0,35 & 0,21 \\
Cunene & 0,59 & 0,2 \\
Cuanza-Norte & 0,53 & 0,25 \\
Cuanza-Sul & 0,74 & 0,34 \\
Luanda & 5,87 & 1,69 \\
Lunda-Norte & 0,87 & 0,22 \\
Lunda-Sul & 0,64 & 0,22 \\
Malanje & 0,61 & 0,24 \\
Moxico & 0,63 & 0,29 \\
Namibe & 0,56 & 0,18 \\
Uíge & 1,26 & 0,39 \\
Zaire & 0,8 & 0,31 \\
\hline Total (\%) & $\mathbf{1 0 0}$ & $\mathbf{1 0 0}$ \\
\hline
\end{tabular}

Fonte: Diário da República de Angola de 30 de dezembro de 2003, p. 2467 e de 30 de dezembro de 2005, p. 3234.

Segundo as estimativas do PNUD e da ONU para o ano de 2002, Angola teria 13.900.000 habitantes ${ }^{17}$ (nove habitantes por $\mathrm{km}^{2}$ ). Do total de habitantes, 43,3\% da população são menores de 14 anos; 53,9\% da população têm 15 aos 64 anos; $2,8 \%$ da população acima dos 65 anos. O crescimento anual da população é de $2,18 \%$, e a taxa de mortalidade infantil é de 191,66 para cada 1.000 crianças nascidas. Os dados do PNUD de 2005 apontam que a expectativa de vida em Angola passou de 40 para 38 anos. Todavia, os dados do Estado (Ministério do Planeamento ${ }^{18}$ ) de 1995 a 2004 apontam uma expectativa de vida de 45 anos para os homens e 48 para as mulheres.

\footnotetext{
${ }^{17}$ Diferente das estimativas do PNUD e ONU para 2002, os dados disponíveis no site do consulado de Angola no Brasil (Rio de Janeiro) mostram um número maior, 20.772.468 habitantes. Os números aparecem distribuídos por província, da seguinte forma: Cabinda, 170.000; Zaire, 50.000; Uige, 1.908.347; Luanda, 3.000.000; Bengo, 500.000; Kwanza-Norte, 400.000; Kwanza-Sul, 2.294.064; Malange, 911.000; Lunda-Norte, 790.000; Lunda-Sul, 400.000; Benguela, 2.000.000; Huambo, 2.075.713; Bié, 1.974.387; Moxico, 750.000; Namibe, 255.000; Huíla, 2.600.000; Cunene, 87.342; Kwando-Kubango, 606.615 habitantes (http://www.consuladodeangola.org/ 13/08/2006).

${ }^{18}$ No Brasil se diz planejamento.
} 
No que tange à situação econômica, em Angola usa-se hoje o Kwanza $(\mathrm{Kz})$ como a moeda nacional $(1 \mathrm{U} \$ \mathrm{D} \approx 80 \mathrm{Kz})$ e o Banco Nacional de Angola (BNA) assume também o papel de Banco central. Em termos de produção, os dados apontavam em 1995 um PNB (Produto Nacional Bruto) de U\$D 410 por habitante ${ }^{19}$. As estimativas do Ministério do Planeamento (2001) apontam que o subsolo angolano é eminentemente rico e, dos minerais mais importantes de Angola, destacam-se o petróleo, gás natural, diamantes, fosfatos, substâncias betuminosas, ferro, cobre, manganês, ouro e rochas ornamentais. Conta ainda com depósitos substanciais de ouro, minério de ferro, fosfatos, cobre, quartzo, gesso, mármore, granito negro, berílio, zinco, etc. A Tabela 3 mostra o crescimento anual, de 2000 a 2006 e a inflação registrada.

Tabela 3: Taxa de crescimento anual do PIB Angolano (2000-2006)

\begin{tabular}{|c|c|c|c|c|c|c|c|}
\hline & 2000 & 2001 & 2002 & 2003 & 2004 & 2005 & 2006 \\
\hline Crescimento (\%) & 3 & 3,1 & 17,2 & 5,2 & 11,7 & 15,5 & 27,9 \\
\hline Inflação anual (\%) & $?$ & $?$ & 96 & 30 & 20 & 17,7 & 10 \\
\hline
\end{tabular}

Até o ano de 2000 Angola tinha uma produção de petróleo de mais de 750.000 barris por dia, o que colocava Angola numa posição de segundo maior produtor de petróleo no continente africano, superado apenas pela Nigéria. Desde 2001 as expectativas de analistas da área econômica apontam para uma produção superior a 1.000.000 de barris de petróleo por dia. No atual momento, em Angola, o "petróleo representa $90 \%$ das exportações naturais, mais de $80 \%$ das receitas do Estado e $42 \%$ do PIB de Angola",20.

O quadro macroeconômico de enquadramento estabelecido no Orçamento Geral do Estado para o ano de 2006 aponta uma produção anual de petróleo (em mil milhões de barris) de 363,5 para 2004; 435,2 para o ano de 2005; e 597,1 para 2006. O produto Interno Bruto conta, no setor petrolífero, com um crescimento de $13,9 \%$ para o ano de $2004 ; 19,7 \%$ para 2005 ; e $37,2 \%$ para 2006 . E quanto ao setor nãopetrolífero, as taxas são de $9,1 \%$ para o ano de $2004 ; 10,4 \%$ para 2005 ; e $11,9 \%$ para 2006 (In: Diário da Republica de Angola, 2005, p. 3213).

\footnotetext{
${ }^{19}$ Cf. http://www.consuladodeangola.org/ 13/08/2006 - 01:50'.

${ }^{20}$ Cf. ib, 13/08/2006 - 01:50'.
} 
As medidas políticas e orçamentais do Estado, traçadas em 2003, prevêem, no domínio do setor empresarial público, a continuidade das ações, em 2006, definidas para o setor empresarial do Estado. Pretende-se continuar o

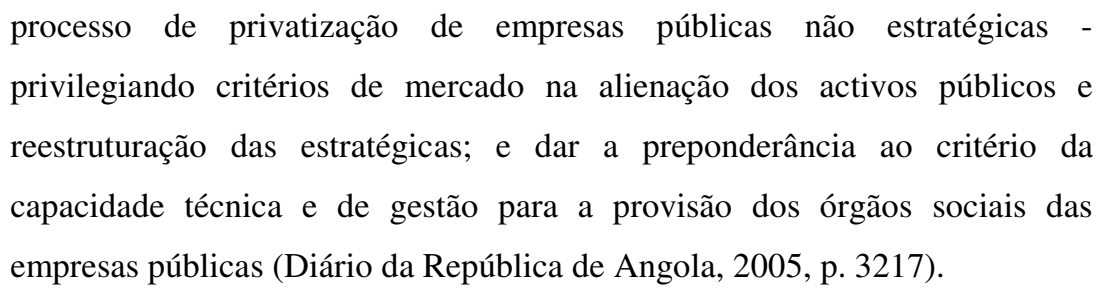

Para esta política foi criado um instituto que cuida das privatizações e sob tutela do Ministério das Finanças, procura tornar cada vez mais eficiente e eficaz o desenvolvimento desse processo de privatizações das empresas angolanas.

É feita também em Angola a exploração de diamantes desde 1912. A empresa Diamang, que fazia a exploração, foi criada em 1917, tendo registrado no seu primeiro ano uma produção de 4.110 quilates e chegado a uma produção recorde de 2.413.021 quilates em 1971. Depois da independência criou-se em Angola (janeiro de 1981) a empresa chamada ENDIAMA, que viria mais tarde substituir a Diamang, dissolvida em 1988. Segundo os dados do Banco Mundial (2002) as exportações oficiais de diamantes subiram dos 295.000 quilates em 1993 para 517.000 em 1994. E as expectativas eram de que, uma vez alcançada a paz, Angola estaria tendo uma produção superior ou igual a 2 bilhões de quilates a partir de 2003.

Os dados mais recentes apontam que a produção de diamantes alcançada até final do " 3 ". trimestre perfaz, em quantidades, 5.345 .535 quilates, correspondendo a $87 \%$ da produção total de 2004 e a um crescimento de cerca de $17 \%$ da produção alcançada no mesmo período de 2004" (Diário da República de Angola, 2005, p. 3208). O crescimento da produção conta com os novos projetos de exploração, dirigidos por empresas estatais e privadas. Na prospecção e pesquisa de diamantes a ENDIAMA associou-se atualmente a vários parceiros, tais como a "Sociedade Mineira do Lucapa, a sociedade Mineira do Catoca, a Chitotolo Associação em participação no Nzagi, entre outros. Pela lei 16/94 são igualmente obrigações da ENDIAMA as operações de classificação e avaliação" ${ }^{21}$ dos diamantes explorados em Angola.

\footnotetext{
${ }^{21}$ Cf. http://www.consuladodeangola.org/ 13/08/2006 - 01:50'
} 
Quanto à energia, o sector elétrico de Angola, cuja atividade é tutelada pelo Ministério de Energia e Águas, tem como principais operadores a ENE (Empresa Nacional de Eletricidade). A ENE é responsável por 95\% da energia elétrica produzida no País e pela distribuição em grande parte, nas principais localidades. A EDEL (Empresa de Distribuição de Energia em Luanda) responde pela distribuição de energia em Luanda. Com a privatização e reconstrução de algumas estruturas (construção de barragens hidroelétricas e extensão dos cabos pelo país) danificadas pela guerra prevêse uma distribuição elétrica e de água mais adequada, dentro dos próximo vinte anos.

A política econômica (industrial) angolana está, depois da guerra (2002), em fase de reabilitação, e muitos esforços deverão ser feitos para atingirem-se taxas favoráveis ao desenvolvimento da vida da população e rever as políticas sociais de distribuição de renda. A agricultura, sobretudo aquela voltada à subsistência das famílias, está paralisada devido às minas espalhadas pelos campos durante a guerra, assim como pela "inexistência de um adequado sistema de conservação e processamento de produção agro-pecuária" (Diário da República de Angola, 2005, p. 3207).

De forma geral, os dados de 2005-2006 apontam uma produção, no setor agrícola, de 100.000 toneladas de cereais, na qual se destaca a produção de milho, feijão e mandioca. Para o setor pesqueiro a produção no mesmo período é de 136.042 toneladas por ano. As produções de couros e outros tipos de peles de animais chegam a 536 toneladas (Diário da República de Angola, 2005, p. 3208).

Apesar da situação deixada pela guerra, afetando diretamente a atividade da agricultura, Angola conta com uma variedade climática favorável ao desenvolvimento agrícola e com uma terra fértil para a produção de café, milho, mandioca, feijão, arroz, algodão, girassol, trigo, etc. O Governo, responsável pelo programa de desminagem, desde o final da guerra tem procurado levar adiante a atividade, por todo o país, de retirar as minas espalhadas pelos campos para garantir maior segurança na circulação das populações. Todavia, os recursos destinados ao programa de desminagem nem sempre são suficientes, diante do quadro do problema de minas espalhadas pelo país, para permitir maior agilidade das atividades e maior articulação dos meios necessários ao desenvolvimento da agricultura em Angola. 


\section{2 - Luta política, acordos de paz e a continuidade da guerra depois da independência}

O ponto de partida desta abordagem é a questão do processo realizado para se concretizar a independência de Angola, que ocorreria em 11 de novembro de 1975. Os rumos em que tudo deveria proceder-se para se chegar à independência de Angola, o ordenamento institucional e a transferência do poder foram estabelecidos pelo Acordo de Alvor, assinado em 15 de Janeiro de 1975, pelos representantes dos três movimentos de libertação de Angola, nomeadamente, a União Nacional para a Independência Total de Angola (UNITA), o Movimento Popular de Libertação de Angola (MPLA) e a Frente Nacional de Libertação de Angola (FNLA), sob a presidência de Portugal.

Conforme estabelece o Acordo de Alvor, discutido de 10 a 15 de janeiro de 1975, em seu Art. 1, o Estado Português reconhece os três movimentos como representantes legítimos do povo angolano e, portanto, portadores do direito de defesa da soberania e independência. E, ainda de acordo com o mesmo documento, todos estes movimentos e o governo português estavam de comum acordo, a um cessar-fogo e à participação destes no governo de transição até a independência.

Para melhor esclarecimento transcrevemos alguns artigos do capítulo três da lei (documento) que regulamentou os Acordos de Alvor.

Capitulo III: Do Governo de Transição.

Art. 14 - O Governo de Transição é presidido pelo Colégio Presidencial.

Art. 15 - O Colégio Presidencial é constituído por três membros, um de cada movimento de libertação, e tem por tarefa principal dirigir e coordenar o Governo de Transição.

Art. 20 - Os ministros do Governo de Transição são designados, em proporção igual, pela Frente Nacional de Libertação de Angola (FNLA), pelo Movimento Popular de Libertação de Angola (MPLA), pela União Nacional para a Independência Total de Angola (UNITA) e pelo Presidente da república Portuguesa, e tomam posse perante o Alto-Comissário.

Art. 21 - Tendo em conta o carácter transitório do Governo, a distribuição dos Ministérios é feita do seguinte modo: 
a) ao Presidente da república portuguesa cabe designar os ministros da Economia, das Obras Públicas, Habitação e Urbanismo e dos Transportes e Comunicações;

b) à FNLA cabe designar os ministros do Interior, da Saúde e Assuntos Sociais e da Agricultura;

c) ao MPLA cabe designar os ministros da Informação, do Planeamento e Finanças e da Justiça;

d) à UNITA cabe designar os ministros do Trabalho, Segurança Social, da Educação e Cultura e dos Recursos Naturais.

Art. 22 - As Secretarias de Estado previstas no presente acordo são distribuídas pela forma seguinte:

a) à FNLA cabe designar um secretário de Estado para a Informação, um secretário de Estado para o Trabalho e Segurança Social e o secretário de Estado do Comércio e Turismo;

b) ao MPLA cabe designar um secretário de Estado para o Interior, um secretário de Estado para o Trabalho e segurança Social e um secretário de Estado da Indústria e Energia;

c) à UNITA cabe designar um secretário de Estado para o Interior, um secretário de Estado para a Informação e o secretário de Estado das Pescas $^{22}$.

A concretização da fase de transição do poder passava por vários condicionamentos, no entanto, o que mais parecia fundamental no devido momento dizia respeito à paz, para que negociações entre Portugal e os movimentos se tornassem possíveis. Cabia ainda ao Governo de Transição a aprovação de uma Lei Fundamental que poderia vigorar até a aprovação da Constituição de Angola e que, segundo Correia (1996, p. 26) "essa lei seria elaborada por uma Assembléia Constituinte que deveria estar eleita e instalada até 31 de outubro de 1975". Estava reconhecido o direito aos movimentos de serem os únicos a candidatarem-se às eleições e isso, afirma Correia (p. 26) “deveria conferir às eleições uma legitimidade democrática dualista, a revolucionária e a representativa".

Em 13 de junho do mesmo ano de 1975 promulgara-se a Lei Fundamental, na qual, a Assembléia Constituinte e um Presidente da República representariam o Estado no momento da independência. Segundo Correia (1996, p. 26), esta Assembléia entraria em vigor até 8 de novembro e, suas funções, no momento da

${ }^{22}$ CORREIA, P. P. Angola: do Alvor a Lusaka. 1996, p. 273-274. 
independência, a 11 de novembro de 1975, todavia, até esta data não estavam preparadas as devidas condições previstas pelo documento aprovado no Acordo de Alvor. A ausência das condições inviabilizou a transferência do poder conforme se acordara formalmente entre os três movimentos e o Estado português. Uma vez violado pelos próprios movimentos até a data prevista, o Acordo de Alvor estava irremediavelmente ultrapassado e, portanto, suspenso pelo Governo Português aos 22 de agosto de 1975, conforme declara o Decreto-Lei n. 458-A/75 (Correia, 1996, p. 27).

A guerra entre movimentos e tropas portuguesas se alastrava, tomando o rumo de uma guerra civil entre os movimentos, e aos poucos ia se internacionalizando através de intervenções externas armadas, a pedido dos movimentos, como uma forma de tentar chegar ao patamar do controle do poder pela força. Ao procurarem esta ajuda externa, o conflito passou também a ter um rumo diferente, isto é, começou a ganhar patamares de conflito regional, não se restringindo apenas ao espaço angolano.

E mesmo diante de uma situação difícil de ser contornada, fruto dos desentendimentos anteriores ao Acordo de Alvor entre os movimentos, e diante do impasse que se vivia no momento, chegada a data do dia 10 para 11 de novembro, à meia noite, o Alto Comissário leu a ordem que o artigo número dois do Acordo de Alvor trazia: ceder a independência aos angolanos.

\footnotetext{
Nestes termos, em nome do Presidente da República Portuguesa proclamo solenemente (com efeito, a partir das zero horas do dia 11 de novembro de 1975) a independência de Angola e a sua plena soberania, radicada no povo angolano a quem pertence decidir das formas do seu exercício (Correia, 1996, p. 27).
}

Assim feito, no dia 11 de novembro, enquanto, por um lado, o MPLA proclamava a independência em Luanda - a República Popular de Angola (RPA), por outro lado, a coligação, UNITA e a FNLA, na província do Huambo, proclamava a República Democrática de Angola (RDA). Contudo, como afirma Correia (1996), a

\footnotetext{
formalização da independência de Angola não se traduziria em qualquer viragem radical na situação que Angola vivia. A guerra iria prosseguir, num cenário que mais não seria do que a continuação do que se verificava antes da independência, ainda que com algumas alterações nos protagonistas e actores secundários (Correia, 1996, p. 27).
} 
Onde estariam os fatores que levaram à guerra entre os movimentos? Quais seriam as raízes do conflito angolano? Além do fato dos movimentos não terem cumprido o que estava proposto e assinado, pelos três, junto ao Governo Português, no Acordo de Alvor, (a integração de seus militares às Forças Militares Mistas), e do fato destes se lançarem à luta armada pelo controle de maior espaço e exercício de seu poder, ajudados por potências externas, existem aspectos que precisam ser analisados para a compreensão da origem do conflito angolano.

O conflito, no qual se entrecruzam uma guerra civil, intervenções externas armadas e interesses econômicos, é anterior ao Acordo de Alvor. Segundo Correia (1996) é necessário considerar quatro componentes na análise e compreensão da complexidade da guerra de Angola:

a) A luta de libertação: "que opunha os movimentos de libertação ao regime colonial português e no terreno, às Forças Armadas Portuguesas" (Correia, 1996, p. 28).

b) $\boldsymbol{O}$ conflito regional: "materializado nos apoios antagônicos que os países vizinhos prestavam aos movimentos de libertação e na colaboração, inclusive no plano militar, da África do Sul com Portugal" (ib, p. 28).

c) O quadro geral da guerra fria: com suas superpotências a disputarem em Angola o alargamento das suas áreas de influência na África $\operatorname{Austral}^{23}(i b$, p. 29).

d) A guerra civil: que comportou vários elementos como, a rivalidade entre os movimentos de libertação e luta armada entre eles, o fato de Portugal colocar "angolanos dos movimentos de libertação contra angolanos incorporados nas Forças Armadas Portuguesas e nas Forças

\footnotetext{
${ }^{23}$ A OTAN (Organização do Tratado do Attântico Norte), através de alguns acordos e compromissos que assinara com Portugal, e o Pacto de Varsóvia (PV) conduziram esta disputa por áreas que mais lhes interessavam, fazendo isto através do apoio mais diversificado e antagônico aos movimentos de libertação. Isto numa fase em que nos Estados Unidos pontificava a dupla Nixon-Kissinger. Como declara Correia (1996, p. 29) o "secretário de Estado norte americano chegou a admitir e a mostrar-se favorável à manutenção, por largo tempo, de uma hegemonia branca na África Austral, através da aliança entre a África do Sul, a Rodésia e as colônias portuguesas". Como mostra Joelle Kuntz, o presidente Nixon teria proposto a Marcello Caetano o seguinte: "Abandonem a Guiné, que não interessa a ninguém. Dêem-lhe a independência. Nós ganharemos tempo e vós, prestígio. Reforçai a pressão em Angola, esta é connosco [...] Vietnamizai Moçambique: dai o norte à FRELIMO, o sul deve continuar do nosso lado" (p. 29). A África Austral se tornara num palco de guerra fria, onde as disputas pelos vários interesses, políticos, econômicos, ideológicos, etc. se entrecruzavam.
} 
Auxiliares (Grupos Especiais, Tropas Especiais e Flechas) que participavam nas operações integrados nas forças portuguesas" (Correia, 1996, p. 31)

Como se nota, tratava-se de vários conflitos civis que se cruzavam no mesmo espaço. Por um lado colocando angolanos contra angolanos, por outro, contra colonizadores e, ainda outro, por interesses econômicos e políticos externos. E toda esta guerra se apresentava, de uma forma camuflada, como a guerra pela libertação. Que libertação? De quem nos libertamos? O prolongamento dos conflitos aos poucos foi ganhando forma, e a conquista do poder, por qualquer meio, estava explícita.

O Acordo do Alvor parecia não resolver o impasse na medida em que não conseguia terminar o conflito que vinha se alastrando em Angola. E aos poucos a guerra foi tomando um caráter diferente daquele que se caracterizava basicamente pela libertação nacional, isto é, a guerra contra o sistema colonial. O país tornara-se um palco de conflitos. A falta de espírito de compromisso com a paz para Angola foi suficiente para minar o espaço que propiciaria uma reconciliação nacional mais duradoura. Isso mostra que não havia interesse pela paz em Angola, mas apenas pelo poder e, esforços não foram poupados para alcançar-se o objetivo. $\mathrm{O}$ apoio externo aos movimentos não faltou. Como afirma Correia (1996),

\footnotetext{
A União Soviética, pelo seu lado, contou com a intervenção militar de Cuba como agente externo na intensificação do conflito leste-oeste no tabuleiro angolano e, como aliado interno, com o MPLA, movimento que apoiou desde o início da luta armada e que iria ver esse apoio substancialmente reforçado (Correia, 1996, p. 34).
}

Desta forma foi desaparecendo do cenário de guerra civil, depois do Alvor, o conflito armado contra as Forças Armadas portuguesas, e reforçou-se ainda mais a outra face da guerra entre movimentos e a intervenção externa. Cada movimento ia delimitando seu espaço, expulsando a presença do outro. O ponto de partida de maior conflito parece começar quando, depois do Alvor, em março de 1975, a FNLA expulsou o MPLA, segundo Correia (1996), dos distritos do Zaire e do Uige. E por outro lado o MPLA também fez outra batalha, agora em Luanda, para expulsar a FNLA da capital. 
Nos dias 16 e 21 de junho de 1975, os líderes dos três movimentos participaram de uma cimeira em Nakuru, Quênia em uma tentativa de reconciliação e fim do conflito. Todavia, como afirma Correia (1996, p. 35), "por pressão da FNLA e da UNITA", Portugal não esteve presente nesta cimeira, situação que contrariava os artigos vigésimo sétimo e qüinquagésimo oitavo do Acordo de Alvor. No final desta resultou um documento, no qual, os três líderes, fazem uma autocrítica e um diagnóstico das causas da guerra civil em curso no país. Mas no final, mais uma vez, este documento não passou de letra morta, pois o conflito continuou, desta vez, com mais intensidade.

Intensificada a guerra, surge também a delimitação do território onde cada um dominava. Segundo Correia (1996),

\footnotetext{
Em princípios de Junho de 1975 estava consumada uma espécie de 'balcanização' de Angola, resultado desta guerra civil. O MPLA dominava a zona envolvente da capital, donde acabava de expulsar a FNLA depois da segunda batalha de Luanda, e controlava Cabinda, a faixa Luanda-Malange, as Lundas e o Moxico. A FNLA era senhora nos distritos do Zaire e do Uige. A UNITA reinava no planalto central. Destas zonas, onde cada um queria exercer um domínio absoluto, os restantes eram expulsos pela força das armas e era-lhes negada qualquer actividade política (Correia, 1996, p. 35).
}

Neste cenário de guerra em que todos estavam envolvidos parece-nos não ser muito seguro afirmar exatamente quem está isento da "culpa" pela guerra, uma vez que todos pretendiam o exercício do poder. E todos colaboraram para que o país se visse tornado em palco privilegiado da guerra fria, ideológica e de conflito regional, na África Austral, com intervenções fomentadas pelos mais diversos interesses, desde o político ao econômico, do hegemônico à subalternalização.

Depois da morte de Agostinho Neto (1979), o MPLA passou a ser liderado por José Eduardo dos Santos. A partir de em Pretória, realizou-se um encontro regional, seguido por um encontro entre Fidel Castro e José Eduardo dos Santos em Havana. Deste último encontro resultou o acordo da retirada das forças militares cubanas do território angolano. Foram postas algumas condições como, a retirada das forças sul-africanas do território angolano e, para a Namíbia, "a realização de eleições e 
a independência deste território nos termos da Resolução 435/78 das nações Unidas e que a Pretória deixasse de apoiar a UNITA” (Correia, 1996, p. 47).

\begin{abstract}
Esta nova tentativa de relançamento do processo de paz em Angola, então com a intervenção directa e destacada dos Estados Unidos, já passava pelo patamar de conflito leste-oeste. A ela estava intimamente ligada a Perestroika e o início do degelo da Guerra Fria, quando Gorbatchev se empenhou na solução pacífica dos conflitos regionais em que era óbvia a influência das duas superpotências. Os seus reflexos diretos no conflito angolano fizeram sentir-se, com Moscou e Washington a recomendarem a Luanda e à Jamba maior flexibilidade na busca de uma solução pacífica e negociada entre ambos (Correia, 1996, p. 47).
\end{abstract}

No ano de 1988 deu-se um rápido desenvolvimento de encontros: duas vezes em Brazaville, uma vez em Londres. Por imposição do "Governo Angolano" (MPLA), a UNITA e a FNLA estiveram ausentes das negociações que se deram em agosto de 1988, em Genebra, para um cessar fogo entre Angola e Cuba de um lado e a África do Sul do outro. Destes encontros resultou, em 22 de dezembro do mesmo ano, a assinatura em Nova Iorque, na sede das Nações Unidas, de um acordo entre Angola, Cuba e África do Sul, concordando com a retirada das tropas cubanas e sul-africanas do território angolano e, finalmente, com a independência da Namíbia. Logo a seguir da assinatura do Acordo de Nova Iorque, segundo Correia (1996, p. 48), “os responsáveis americanos, primeiro o novo presidente George Bush, depois o novo sub-secretário de Estado para os assuntos africanos Herman Cohen, fizeram saber que não deixariam de prosseguir com o seu apoio à UNITA”.

Um sinal verde iria surgir quando, em 1989, o presidente do Zaíre (atual Congo Democrático) Mobutu, toma a iniciativa de convidar para a cimeira de junho, que contou com a presença de vários Estados africanos e representantes, José Eduardo dos Santos e Jonas Savimbi (líder da UNITA). Desta cimeira resultou o primeiro aperto de mão desde que se haviam dividido pela guerra. E nesta mesma data de 24 de junho o MPLA e a UNITA assinam um cessar-fogo em Angola. Todavia, a resposta contrária não tardou. Em julho do mesmo ano os Estados Unidos fizeram saber que eram contra o plano de paz para Angola. 
Minada a iniciativa de paz, o conflito angolano iria prolongar-se até finais de 1989 e janeiro de 1990, com o ataque das Forças Armadas Populares de Libertação de Angola (FAPLA) na região de Mavinga, próxima à sede do quartel general da UNITA. Isso levou Jonas Savimbi a abandonar sua visita a Portugal para, imediatamente, voltar a Angola em defesa de seu território.

Contudo, as iniciativas decorrentes ao ano de 1989 permitiram que mais uma tentativa de negociações fosse realizada. E isso se concretizaria com a assinatura do Acordo de Bicesse, no qual Portugal iria assumir o papel de mediador. As condições até aqui verificadas em Angola favoreciam essa oportunidade de negociações, uma vez que vários aspectos da guerra angolana haviam mudado, Angola deixara de ser o palco da Guerra Fria entre as superpotências e as intervenções militares externas tinham terminado.

De um lado, por parte do "governo angolano" (MPLA) havia sinais favoráveis a mudanças e negociações, com propostas de mudanças constitucionais, o que permitira a possibilidade de abertura ao multipartidarismo e, portanto, a participação da UNITA na vida política do país. Por outro, além dos Estados Unidos e a União Soviética situarem-se no plano de observadores das negociações, também estavam de acordo quanto à política de terminar o fornecimento de armamento para os dois lados dos movimentos angolanos. Como afirma Correia (1996),

\footnotetext{
A assinatura formal dos acordos pelo presidente da República Popular de Angola, José Eduardo dos Santos, e pelo presidente da UNITA, Jonas Malheiro Savimbi, viria a verificar-se em Lisboa, no Ministério dos Negócios Estrangeiros, em 31 de Maio de 1991, com a presidência do primeiro ministro português Cavaco Silva, e a presença do secretário-geral das Nações Unidas Peres de Cuellar, dos responsáveis pela política externa dos Estados Unidos e da União Soviética, James Baker e Alexandre Brassmertnykh e do presidente da Organização da Unidade Africana Joweri Museveni (Correia, 1996, p. 52-53).
}

Assinado o Acordo de Bicesse, começariam, dentro de pouco tempo, as discussões, mesmo com algumas precipitações e em tempo tão curto de preparação, sobre as eleições legislativas e presidenciais marcadas para 29 a 30 de setembro de 1992. Mas parece que a experiência do Acordo de Alvor nada valeu. Repetiram-se 
alguns erros, como o não acantonamento adequado das forças militares da UNITA e MPLA, a desmobilização incompleta, o desarmamento das forças militares não concluído e a constituição das Forças Armadas Angolanas (FAA), na qual estariam integradas tanto as Forças Armadas Populares de Libertação de Angola (FAPLA) do governo, quanto as Forças Armadas de Libertação de Angola (FALA), da UNITA, para juntas formarem um único exército militar para o país, não foi concretizada.

Diferente do Alvor, Bicesse contava com a presença de Órgãos Internacionais, como a UNAVEN I (Missão de Verificação das Nações Unidas em Angola), as Nações Unidas, etc. Possuía potencialidades suficientes e melhores, comparado à fase do Alvor, para que tudo desse certo. Mas a confiança na boa vontade dos dirigentes, de um e do outro, e a pouca intervenção das forças militares da ONU, fez com que pouco ou nada se obtivesse de êxito para o fim do conflito angolano, isto é, o estabelecimento da paz. Logo depois das eleições de setembro de 1992 viriam à tona os pontos fracos (a não conclusão do processo de desmobilização militar, da formação de um único exército nacional, da integração dos membros da UNITA aos cargos civis, etc.) não superados nas negociações, resultando novamente à volta a guerra.

Esta constituiu uma fase em que muitos angolanos perderam a confiança nos órgãos internacionais, uma vez que pouco ou nada fizeram para impedir tal situação, e nos dirigentes que tudo faziam para defender o poder sem ter em conta a condição social em que estavam colocando o país. A guerra que começou depois das eleições de 1992 também marca a fase mais destruidora de Angola, desestabilizando as infra-estruturas econômicas. Esta criou uma situação social muito precária para as populações, com a destruição completa de cidades como Huambo e Bié.

As famílias se desestruturaram e a esperança na paz passou a significar a espera pelo que nunca chega. Passou-se mesmo a pensar, por parte da população, que lhes estava retirado ou roubado o direito à vida digna e à paz. Vítima do conflito leste-oeste, do conflito regional da África Austral, da experiência democrática das eleições presidenciais e legislativas - sob direção das Nações Unidas, na qual se depositara confiança, o povo encontrava razões fortes para perder a credibilidade no trabalho daqueles a quem competia resolver as questões de paz para Angola.

A guerra que se seguiu às eleições foi marcada por uma série de medidas e Resoluções tomadas pelo Conselho de Segurança das Nações Unidas e pela aplicação de várias sanções à UNITA, como forma de pressioná-la a negociar e a 
reconhecer os resultados das eleições de setembro de 1992, das quais o MPLA saíra vitorioso. O ponto mais alto destas medidas e resoluções viria fazer-se valer com a assinatura do Acordo de Paz para Angola em Lusaka, aos 20 de novembro de 1994, cinco dias após a data prevista.

Não muito diferente do Acordo de Alvor e Bicesse, o Acordo de Lusaka visava em primeiro lugar à formalização de um cessar fogo de maneira a criar-se condições políticas necessárias para a reconciliação nacional entre as partes envolvidas na guerra. Este novo acordo não ignora o anterior (Bicesse), muito pelo contrário reafirma a necessidade da sua conclusão e, com isso, coloca em funcionamento aquelas instituições que resultaram das eleições realizadas nos dias 29 e 30 de setembro de 1992. Enquanto no Acordo de Alvor, segundo Correia (1996) se;

\footnotetext{
estabelecera uma fórmula de partilha paritária do poder, para um período de transição, até à realização de eleições que precederiam a independência, e em Bicesse se assentara na definição de condições equilibradas para um período de transição, sem partilha do poder mas com participação paritária em órgãos de fiscalização que deveriam preparar eleições, em Lusaka o que estava em causa era, no respeito pelos resultados de eleições já efectuadas, encontrar uma modalidade de participação nas instâncias do poder da parte contratante derrotada nas eleições (Correia, 1996, p. 151).
}

Outro aspecto fundamental é que, enquanto no Acordo de Alvor e no de Bicesse, predominara a necessidade do cumprimento das datas, mesmo sem a concretização das condições fundamentais, isto é, a realização das obrigações que os documentos apresentavam, o Acordo de Lusaka punha como condição fundamental o cumprimento de cada tarefa para que se passasse à fase seguinte. Ou seja, o início da realização de uma etapa estava sempre condicionado à conclusão da anterior, o que implicaria na mudança das datas caso determinada atividade não fosse realizada no seu devido período marcado.

No Acordo de Lusaka o papel conferido às Nações Unidas também se diferenciou muito daquele que, a elas, fora conferido nos Acordos anteriores. E isso se apresentava como uma condição fundamental e indispensável. As Nações Unidas e o Conselho de Segurança tomaram para si o papel de mediadores principais do processo e as Resoluções tomadas pelo Conselho de Segurança tornaram-se pontos de referência 
fundamentais. Reforçaram-se os efetivos militares das Nações Unidas e sua intervenção, ampliaram-se suas missões, passando do papel de mera observação e fiscalização ao de interveniente, como se esperava, dentro do quadro de "forças armadas de manutenção de paz”. A presidência da Comissão Conjunta de negociações de paz para Angola foi assumida pelas Nações Unidas.

No entanto, as medidas tomadas pelas Nações Unidas não impediram que os conflitos continuassem. Nos últimos anos a guerra intensificou-se, vindo a culminar com a morte de Jonas Savimbi (líder da UNITA) em fevereiro de 2002. Estava assim fechada a página da guerra que, por um lado desde 1975 destruía o país, sacrificando milhões de vidas inocentes, mas que, por outro lado beneficiava, materialmente, aqueles que viam nela a grande possibilidade de enriquecimento e acumulação do capital econômico e a possibilidade de alcançar e permanecer no poder em Angola.

\section{3 - Recrutamento de adolescentes-soldados durante a guerra}

A guerra que decorreu em Angola, entre outros problemas, também agravou a vida das crianças e, sobretudo, de adolescentes ${ }^{24}$ que tiveram que abandonar precocemente a escola por se verem obrigados a integrar-se nas forças armadas como soldados. Isso ocorreu tanto em locais controlados pelo MPLA como em locais sob o domínio da UNITA. A entrevista feita pela Human Rights Watch ${ }^{25}$ em dezembro de

\footnotetext{
${ }^{24}$ Quando falamos em adolescentes referimo-nos às crianças com a idade compreendida entre os 15 a 17 anos. A Human Rights Watch trata de crianças-soldados todos os menores de dezoito anos que foram integrados obrigatoriamente ao serviço militar. Vale lembrar que a lei de Angola não permite que menores de dezoito anos sejam integrados ao serviço militar obrigatório. O decreto de Angola de 1996 sobre a aplicabilidade do serviço militar estabelece que a idade mínima para o recrutamento voluntário é de 18 anos para os homens e 20 anos para as mulheres (Lei Constitucional da República de Angola, art. 152(2). Recrutamento; Lei $\mathrm{n}^{\circ}$. I/93 para a idade de vinte anos; Decreto ${ }^{\circ}$. 40/96 de 13 de dezembro de 1996 para dezoito anos e serviço militar voluntário). A Carta Africana que trata dos Direitos e Bem-estar da Criança aponta a não participação de menores de dezoito anos nas hostilidades de guerra e aponta ainda que devem ser tomadas todas as providências de modo a impedir que crianças sejam afetadas pela guerra e que devem ser providenciados todos os cuidados necessários ao seu bem-estar social. A Carta Africana de Direitos e Bem-Estar das Crianças, art. 22 foi ratificada por Angola em 1992 e a Convenção dos Direitos das Crianças afetadas por conflitos armados em 1990 (Human Rights Watch, 2003).

${ }^{25}$ A Human Rights Watch é uma organização que se dedica à proteção dos direitos dos povos no mundo todo. O relatório das entrevistas é uma pesquisa realizada em Angola em novembro e dezembro de 2002 nas províncias de Luanda, Bié e Moxico. Os pesquisadores da Human Rights Watch entrevistaram adolescentes ex-combatentes que haviam combatido nas FALA (UNITA) e nas FAA (Governo). Os rapazes foram entrevistados individualmente e as meninas, em grupos porque não foi possível combinar
} 
2002 aos adolescentes militares, no momento da desmobilização, comprovou o "uso de crianças" como soldados para carregamento de material bélico nas FAA - Forças Armadas Angola (do governo), nas FALA - Forças Armadas de Libertação de Angola (UNITA) e também como combatentes em ambos os lados.

Depois da assinatura de acordos entre a UNITA e o governo em Abril de 2002 iniciou-se um programa de desmobilização de militares. A maior parte dos desmobilizados, maiores de dezoito anos receberam documentos, um salvo-conduto, um pagamento de cinco meses de salário de acordo com a graduação militar de cada um, além de subsídio de alimentação. Estes desmobilizados poderiam ainda receber um subsídio de transporte e equipamento para uma devida reintegração social e volta às suas localidades de origem. Todavia, diferente daqueles maiores de dezoitos anos, os adolescentes (15 a 17 anos, outros, com menos de 15 anos) não foram contemplados com os mesmos benefícios, não recebiam documentos de identificação ou auxílio alimentar distribuído pela comunidade internacional às comunidades ligadas àqueles soldados. Diante dessa situação a Human Rights Watch concluiu que este programa de desmobilização

discrimina contra as crianças e adolescentes, muitos dos quais tiveram as mesmas incumbências que os adultos durante o conflito. Ele agrava a injustiça que estas crianças já enfrentaram: o uso de crianças no conflito armado é expressamente proibido pela Carta Africana sobre os Direitos e o Bem-estar da Criança, e a participação das crianças em conflitos armados está entre as piores formas de trabalho infantil, conforme se define na Convenção sobre as Piores Formas de Trabalho Infantil. Como signatário destes instrumentos, o governo de Angola assumiu a obrigação geral de cuidar, proteger, recuperar e reintegrar as crianças afetadas pelos conflitos armados (Human Rights Watch, 2003, p. 4).

Segundo a Human Rights Watch há pouca assistência a adolescentes que combateram em ambos os lados durante a guerra e isso compromete a integração destes adolescentes de ambos os sexos na vida social, familiar e em suas cidades de

com as autoridades dos acampamentos a realização de entrevistas confidenciais e privadas com as meninas. As informações atinentes a abuso sexual que estas jovens adolescentes sofreram foram retiradas das pesquisas feitas anteriormente em 1998 e 1999 pela Human Rights Watch. A equipe da Human Rights Watch também conversou com "líderes militares tanto anteriores como atuais, representantes de organizações não governamentais (ONG) nacionais e internacionais, membros do clero, funcionários da Organização das Nações Unidas e autoridades do governo" (Human Rights Watch, 2003, p. 7). 
origem. Em 1994, quando foi assinado o Protocolo de Lusaka houve um período de cessar-fogo e nesta fase tinham sido inscritos no programa de desmobilização, segundo a Human Rights Watch, 9 mil adolescentes do sexo masculino provenientes de ambos os lados (UNITA e MPLA).

Não há dados exatos do número de adolescentes que combateram durante todo o período da guerra em Angola (1975-2002) em ambos os lados. Contudo, para os últimos anos de conflitos (1998-2002) a "Coligação pelo Fim do Uso de Crianças-Soldados estima que 7.000 crianças serviram nas forças da UNITA e com as Forças Armadas Angolas, (FAA), do Governo"26. Há outros dados, como os de "pessoas envolvidas com a proteção de crianças em Angola [informando] que pode chegar a 11.000 o número de crianças em ambos os lados, que possivelmente viveram e trabalharam em condições de combate" (Human Rights Watch 2003, p. 4-5).

Os adolescentes soldados eram treinados tanto para o combate como para trabalhos, como carregadores de material, cozinheiros ou informantes, o que os punham em uma condição de risco de vida. Nas descrições que a Human Rights Watch apresenta, através das entrevistas feitas a crianças e adolescentes comprova-se não só os maus tratos por que passaram estas crianças como também a violação dos direitos internacionais de crianças, assim como, no lado do governo, a violação das leis em vigor em Angola, uma vez que também estas não permitem a incorporação obrigatória de indivíduos menores de dezoito anos. Do lado da UNITA, como mostra a Human Rights Watch

\footnotetext{
As meninas ou adolescentes serviam na UNITA como criadas ou serviçais, ajudantes e "esposas" para os soldados. As mulheres e adolescentes também eram forçadas a servir de "mulheres de conforto" a convidados da UNITA em visita às áreas que esta dominava na guerra. Depois da guerra, muitas destas jovens eram agora mães morando nas áreas de aquartelamento, com ou sem seus "maridos". Outras jovens viviam com seus familiares e não eram tão facilmente identificáveis como grupo separado. No processo de desmobilização que se seguiu ao Protocolo de Lusaka, as jovens não foram incluídas em nenhuma programação formal. As jovens que viveram e trabalharam sob condições de combate não recebem atualmente nenhuma
}

\footnotetext{
${ }^{26}$ Coalizão pelo Fim do Uso de Crianças-Soldados. Relatório Global sobre Crianças-Soldados de 2001. 12 de junho de 2001.
} 
assistência específica e é grande o risco de que suas necessidades sejam mais uma vez ignoradas (Human Rights Watch, 2003, p. 5).

A partir de 2002 as crianças desmobilizadas receberam ajuda, ainda que insuficiente, de organismos internacionais para suprir as condições básicas de alimentação e assistência médica àqueles que se encontravam em áreas de aquartelamento. Uma das dificuldades enfrentadas por estes organismos que forneciam ajuda devia-se à inacessibilidade e à falta de estradas ou às más condições das existentes, muitas vezes, com muitos buracos devido a minas ou ainda pontes destruídas durante a guerra.

As entrevistas realizadas pela Human Rights Watch na província do Bié, no dia 28 de novembro, e na província de Moxico, no dia 2 de dezembro de 2002 comprovaram também o uso de crianças adolescentes pelas Forças Armadas do governo (MPLA) durante a guerra.

O governo de Angola também usou crianças-soldados [durante] a guerra, apesar das leis nacionais proibirem seu recrutamento obrigatório. Muitas foram recolhidas e forçadas a combater pelas FAA durante esforços de recrutamento em áreas dominadas pelo governo. Alguns rapazes recebiam treinamento sobre o uso das armas e combatiam nas linhas de frente. Outros trabalhavam como operadores de rádio e na execução de reparos mecânicos. Em cooperação com agências internacionais, o governo liberou alguns rapazes que guarneciam posições na capital, Luanda, em 2002. Observadores que trabalhavam nas províncias informaram à Human Rights Watch que soldados menores de idade ainda serviam nas FAA em áreas rurais, geralmente longe do escrutínio da comunidade internacional (Human Rights Watch, 2003, p. 5-6).

As estimativas do número de adolescentes que foram arregimentadas pelas tropas do Governo são mais de 3 mil jovens do sexo masculino (Coalizão pelo Fim do Uso de Crianças-Soldados, 1999). O recrutamento obrigatório ocorria, sobretudo, em bairros mais pobres. Os jovens eram levados obrigatoriamente de suas casas, durante à noite, para os locais de aquartelamento. Os adolescentes recolhidos, dependendo da postura do corpo, eram mandados de volta para suas casas; outros, enviados a outras províncias para o treinamento, eram forçados ao trabalho militar. 
Ainda segundo a Human Rights Watch também os adolescentes desligados das FAA em 2002 não receberam quaisquer benefícios que pudessem integrá-los às suas comunidades de origem, às suas famílias, a programas de ensino e saúde. Isso torna a situação ainda mais antagônica, uma vez que o Governo angolano havia assumido o compromisso por Angola de cuidar de todas as crianças adolescentes vítimas do processo da guerra armada e de recuperá-las. A Human Rights Watch apresentou também a necessidade de promover-se uma formação que visasse maior integração destes adolescentes assim como de fazer-se um acompanhamento psicológico e social específico para uma melhor integração de adolescentes e crianças.

\footnotetext{
Durante a visita da Human Rights Watch a Angola, os pesquisadores reuniram-se com oficiais das FAA e ex-oficiais da UNITA, bem como com representantes dos governos nacional e provinciais. Cada um citou razões diferentes pelas quais as crianças não foram incluídas no processo de desmobilização, porém indicaram que as crianças não podiam ser integradas às FAA e, portanto, não se qualificavam a participar do programa. De acordo com uma pessoa que trabalha na área de assistência internacional, o programa foi criado de forma que o governo pudesse evitar o custo de pagar benefícios a mais 7.000 ex-combatentes e evitar atrair atenção sobre a questão potencialmente embaraçosa do uso generalizado de crianças-soldados em Angola, particularmente pelas FAA. Como comentou essa pessoa da área de assistência, nenhuma autoridade do governo nega que as crianças tenham sido utilizadas na guerra, mas simplesmente afirmam que as crianças não se qualificam aos programas existentes. $\mathrm{O}$ fato da questão das crianças-soldados não ter sido tratada normalmente durante as negociações parece sugerir que a UNITA não exerceu pressão para a sua inclusão, ou então o governo não estava disposto a oferecer nenhuma solução concreta (Entrevista da Human Rights Watch, Luanda, 26 / 11 / 2002. In: Human Rights Watch, 2003, p. 19).
}

A comunidade internacional tem contribuído para um planejamento em conjunto com o governo na criação de alguns programas comunitários de reabilitações de crianças, familiares e comunidades, todavia segundo a Human Rights Watch (2003) nestes programas não se faz "menção específica às crianças-combatentes, supostamente porque tal identificação prejudicaria sua integração" (ib, p. 6). Apesar destes programas poderem fortalecer a coesão comunitária a curto prazo, "sua omissão na escolha específica de crianças-combatentes de ambos os sexos como alvo de 
programas reconhecidos indica que muitas destas crianças e suas necessidades específicas" (ib, p. 6), no que concerne à recuperação e reabilitação, continuarão sendo ignoradas. Além disso "presume-se que estas crianças ex-combatentes disponham de famílias e das comunidades para prestar-lhes assistência, o que nem sempre acontece" (ib, p. 6).

Nota-se então que a integração efetiva de crianças ex-combatentes depende muito do nível de acesso aos serviços básicos de saúde, educação, acompanhamento psicológico e social disponibilizado às comunidades. E por outro, apesar de haver organizações não governamentais que apóiam projetos de integração de crianças, assim como as agências das Nações Unidas que ajudam nas atividades humanitárias de desenvolvimento, também cabe ao Estado angolano responsabilidade na garantia de direitos e deveres, manutenção dos programas de saúde e reabilitação familiar e de integração de adolescentes ex-combatentes.

Outra situação que também surge com a guerra é a presença elevada de crianças e adolescentes nas ruas das cidades. Fenômeno marcante desde 1981, quando se deu a destruição da província de Cunene. A presença de crianças nas ruas levanta outra discussão, uma vez que elas não admitem serem chamadas de "meninos de rua”. A pesquisa de campo (mestrado defendido na UFES) realizada em Luanda por António Miguel André27 mostra como as crianças negam serem chamadas de meninos de rua. Elas mesmas denominam-se "meninos de Estado", justificando que se elas estão nas ruas deve-se ao fato de o Estado ter realizado a guerra.

Para as crianças e outros entrevistados por Antonio M. André "tanto os que moram nas ruas como os que vão às ruas em busca de sobrevivência não devem ser chamados de meninos de rua, mas sim meninos de Estado" (André, 2001, p. 128). Os entrevistados na pesquisa de André mostram-se conscientes da situação política e de guerra que Angola atravessou, porém, mostram-se também otimistas quanto ao seu futuro. Seus argumentos são expressos mediante o "discurso do descaso do Estado para com a sua futura geração, discordando do significado da terminologia usualmente atribuída aos meninos e meninas que se encontram na rua”, pois estes entendem que o

\footnotetext{
${ }^{27}$ André, A. M. Meninos de rua ou meninos de Estado: A educação não-formal em Angola. Neste artigo, que resultou da dissertação de mestrado, os entrevistados aparecem com nome fíctício escolhido pelos entrevistados. O autor trata da vida dos que se encontram nas ruas de Angola e mostra como este fenômeno surge.
} 
"termo que melhor se aplica a tal situação e explica-a é menino de Estado" (André, 2001, p. 141).

Nas suas justificativas, as crianças e outros entrevistados, a que Antonio M. André se refere em sua pesquisa, atribuem a responsabilidade ao Estado pela sua condição de vida. Suas falas "baseiam-se na história do país e afirmam que, mesmo no período colonial, a população angolana vivia sob situação de miséria, mas tal fato não se registrava" (André, 2001, p. 128). Segundo um dos entrevistados por André

Os pais sempre protegeram seus filhos, mesmo noutra experiência que foi a fase considerada de passagem para o socialismo, a população tinha como manter seus filhos em casa e sob seu controle, as famílias tinham uma economia doméstica que possibilitava satisfazer seus membros, assim como tinham possibilidades de levar seus filhos à escola, os filhos na família constituem o símbolo, o escudo de um lar. Assim sendo, não é possível que os pais deixem seus filhos viverem completamente na rua (Eduardo, 1996. In: André, 2001, p. 128).

O estudo realizado por André mostra que esta visão expressa por Eduardo é comum entre a população angolana. O que faz com que seja complexo falarse em crianças de rua. Parece uma grande desconsideração tanto para a família como para as crianças que se encontram nestas condições denominá-las de "meninos de rua" e ressalta-se que "os demais fatores que condicionam o aparecimento de meninos de rua é fruto de má gestão do Estado" (André, 2001, p. 129).

A guerra permitiu, além do surgimento de crianças sem famílias, vivendo nas ruas, e de crianças ex-soldados, sem uma boa integração social, um êxodo rural elevado, deslocações constantes de populações, desagregação familiar, distorção dos valores culturais e morais e crescimento econômico lento comparado ao crescimento demográfico. O desafio que se apresenta hoje consiste na busca de uma maior responsabilidade política e na tomada de medidas exaustivas para as áreas de educação, saúde e reinserção social destas crianças que, como outros angolanos, são vítimas do processo complexo de guerra e lutas pelo qual Angola passou desde a independência colonial. Tornar as crianças, afetadas pela guerra, uma prioridade no atendimento às necessidades básicas depende de medidas políticas e sociais que vão além da simples vontade política. 


\section{CAPÍtULO II}

\section{A PRÁXIS EDUCACIONAL EM UM CONTEXTO DE INSTABILIDADE SOCIAL E POLÍTICA E DE LUTA PELO PODER}

O contexto histórico e sóciopolítico de Angola, tratado no primeiro capítulo, permitiu-nos entender o quanto é complexo falar de política educacional neste contexto predominantemente instável devido à situação de guerra civil. A análise dos fatores que determinaram a construção das relações de lutas ideológicas que desembocaram na guerra entre os movimentos políticos antes e depois da data de 11 de novembro de 1975, feita também no capítulo anterior, contribui, no presente capítulo, para maior compreensão do contexto histórico-educacional, das relações de luta pelo poder, que de uma forma ou de outra se disseminaram no espaço educacional, da forma de construção de uma ordem visando assegurar o poder implantado, assim como da formação de professores e sua atuação no espaço escolar.

Também é fundamental analisarmos, de um lado, o discurso político construído em torno da guerra e das razões, pelas quais determinadas "justificativas"28 institucionalmente consideradas certas em função da ideologia política de poder defendido ganharam "legitimidade" e, por outro lado, as verdades que os fatos ${ }^{29}$ não deixaram de mostrar ao longo dos anos posteriores à independência angolana. Pensar fora dos trâmites das relações construídas e as verdades institucionalizadas, produtos da trajetória de guerra que se deu entre os movimentos político-partidários, constitui um desafio que todo intelectual e investigador angolano (preocupado com a educação) enfrentará para poder esclarecer a situação de guerra e a repercussão desta na educação.

\footnotetext{
${ }^{28}$ Referimo-nos à negação da legitimidade e representatividade dos interesses de outros partidos políticos, enquanto manifestação de um ideário diferente para Angola; a defesa da legitimidade do poder administrativo centralizado; e o atendimento aos interesses do capital econômico estrangeiro, que no final da guerra (1974) contra o colonialismo, se faziam presentes em grande escala, no território angolano, como forma de garantir a ajuda política e militar em defesa de poder.

${ }^{29}$ Estamos nos referindo à pouca consistência política dos programas sociais, ausência de mecanismos jurídicos que pudessem garantir os direitos fundamentais - saúde, educação e trabalho, etc.
} 


\title{
1 - Formação e atuação de professores nas escolas
}

\author{
É necessário que cada membro ativo da sociedade compreenda o quê é \\ preciso construir e de que maneira é necessário fazê-lo. Tal postura leva à \\ valorização do trabalho coletivo e à criação de formas organizacionais \\ eficazes (Pistrak, 1981, p. 11).
}

Quando se estrutura uma política educacional, além de se pensar em questões ligadas às infra-estruturas, aos conteúdos e aos meios financeiros pensa-se também no corpo docente, isto é, na formação de professores - aqueles que irão executar e fazer valer tal política educacional. A citação de Pistrak $^{30}$ ajuda-nos a pensar que é vital, cada um dos professores, compreender como, por que e o quê é importante construir (para o Estado e para a sociedade). Desta forma se valoriza tanto a atividade coletiva, a ser realizada no espaço escolar, como o desenvolvimento da atividade de ensino. Pistrak (1981) compreende que para transformar a escola e para colocá-la a serviço da transformação social não basta alterar os conteúdos nela ensinados. É preciso mudar a prática educativa, a estrutura de organização e funcionamento da escola, tornando-a coerente com os objetivos de formação de um cidadão capaz de participar ativamente do processo de construção da sociedade. Os três aspectos centrais da obra de Pistrak, objeto de discussão dos educadores, são as reflexões sobre a relação entre escola e trabalho, a proposta de auto-organização dos estudantes e a organização do ensino através do sistema de complexos temáticos.

Os princípios apontados por Pistrak para nortear a atividade de professores são: saber lutar e saber construir. E a escola do trabalho tem como grandes fundamentos as relações da escola com a realidade atual e a auto-organização dos estudantes. A grande preocupação de Pistrak é entender como a escola poderia ajudar a consolidar a revolução socialista, e para isto o que via como fundamental era a

\footnotetext{
${ }^{30}$ Na obra "Fundamentos da escola do trabalho", escrita em 1924, Pistrak procura sistematizar sua experiência pedagógica na condução da escola Lepechinsky e no contato com outras escolas primárias de sua época, buscando traduzir para o plano da pedagogia escolar os ideais, as concepções, os princípios e os valores do processo revolucionário inicial na União Soviética. Pistrak contribui com sua prática para os estudos e reflexões a que hoje chamamos de pedagogia socialista. Uma pedagogia centrada na idéia do coletivo e vinculada ao movimento mais amplo de transformação social.
} 
formação dos sujeitos deste processo, não no futuro, mas já no presente. Para Pistrak (1981) as crianças e os jovens tinham um lugar destacado na construção da nova sociedade soviética. Mas para isso precisavam ser educados ao mesmo tempo com muita firmeza ideológica e política nos princípios e valores da revolução e com muita autonomia e criatividade para ajudar a recriar as práticas e as organizações sociais. A preocupação consiste em refletir sobre a questão de como vincular a vida escolar, e não apenas seu discurso, a um processo de transformação social, fazendo dela um lugar de educação do povo para que ele se assuma como sujeito da construção da sociedade.

Partindo da abordagem de Pistrak para o nosso contexto em pauta, podemos dizer que a estabilidade e o desenvolvimento do processo educacional dependem não somente do ideário político vigente no discurso dos governantes, mas das relações de gestão pedagógica e poder estabelecidas e, sobretudo, dos interesses e objetivos que se pretendem alcançar a longo e curto prazo com esta educação. Daí a importância da análise e reflexão sobre a formação dos professores e da compreensão da política que ao longo destas últimas três décadas delineou o processo educacional angolano.

O nível de formação de professores durante os últimos trinta anos era na sua maioria a oitava classe ${ }^{31}$ ou ensino médio (técnico médio de professor). E ainda em nossos dias parece continuar a mesma situação, pois o Ministério da Educação (2001) tem apresentado dados que comprovam a falta de professores qualificados para as atividades de ensino escolar. Como exemplo coloca-se aqui o número de professores registrados, de 42.135, em 1998, para as atividades de ensino, sendo que a maioria, segundo o Ministério da Educação (2001), não possui os requisitos necessários (formação) para poderem atuar no ensino fundamental (primeira à oitava classe).

De acordo com o Ministério da Educação (2001), para que um professor exerça suas atividades de ensino na iniciação e primeiro nível deve, necessariamente, possuir o ensino médio (normal ou técnico) completo. Todavia, "em Luanda, dos 6.413 docentes existentes, 50,2\% não possuem as habilitações adequadas". Dos 7009 professores que atuam na província da Huíla, 93\% não possuem o ensino médio normal recomendado. Na província de Cabinda também se repete a mesma situação, os professores do primeiro nível sem habilitações requeridas atingem $87,7 \%$. Na província do Kuando-Kubango, dos 421 professores que atuam no primeiro nível,

\footnotetext{
${ }^{31}$ Oitava série no Brasil
} 
quase ninguém está preparado para lecionar neste nível (Ministério da Educação, 2001, p. 21. vol. 5). Esta situação se repete em várias outras províncias e em níveis posteriores $\left(5^{\mathrm{a}}\right.$. e $6^{\mathrm{a}}$. classes)

A formação do professor, uma vez que ela não é alheia à política vigente no país, justamente por ser pensada a partir de uma estrutura fixa, encontra vários obstáculos, e estes repercutem no trabalhado desenvolvido. Como afirmava Dário de Melo no prefácio do livro de Peterson, dos poucos professores existentes, muitos são encarregados com tarefas não docentes, às vezes como forma de melhoria das condições salariais. "Há uma estrutura hierárquica pesadíssima. Para mais, sabendo que se chega a este topo hierárquico pelo processo simples de nomeação, que não o das habilitações, o da competência ou do concurso público" (In: Peterson, 2003, p. 13).

Outro problema também patente, que se notou durante os anos que sucederam a independência, é o da não elevação contínua (formação continuada) do nível acadêmico do professor. A formação pedagógica dos professores, segundo Perteson (2003), limitou-se, praticamente ao treinamento das técnicas de ensino, formas de transmissão do conteúdo sem, no entanto, haver um domínio e conhecimento exato daquilo que deveria ser ensinado. Esta situação, registrada durante vários anos, ainda continua no ensino básico, sobretudo nas províncias ou localidades mais afastadas das cidades.

Entendemos que quando o sistema de ensino é organizado a partir de uma estrutura hierárquica flexível e eficaz, do qual o professor pode, não apenas depender, em termos burocráticos, mas participar, criticar e sugerir situações que visem à melhoria do ensino contribui para o enriquecimento da formação do docente. No entanto, o mais comum, segundo Melo (2003), é que "apesar das deficiências pedagógicas e culturais que afligem os nossos quadros docentes, cresceram desmensuradamente as chefias escolares: todos os professores são mais ou menos directores ou coordenadores de qualquer coisa" na escola (In: Peterson, 2003, p. 13). Quando todos mandam, isto é, todos são "chefes" e querem permanecer neste cargo, não ocorrem mudanças suficientemente sustentáveis para a melhoria da atividade profissional.

Com isto não pretendemos defender a centralidade do poder administrativo escolar, mas que a participação dos professores, nas atividades escolares, se dê de uma forma responsável, não se desligando por isso de sua formação continuada 
e atuação em sala de aula. O objetivo é tentar aumentar a eficiência que não há, a partir de um controle de responsabilidade pelo trabalho escolar. A questão é: quem orienta, quem determina numa escola onde todos mandam? Que medidas tomar para a melhoria da atividade escolar, das relações entre professores e da administração pedagógica? Os estudos, até agora realizados, apontam para a necessidade de se buscar maior envolvimento de professores e coordenadores escolares para maior direcionamento das atividades escolares, assim como para um ordenamento pedagógico mais eficiente dos trabalhos na escola.

A presença de um ou mais dirigentes não exclui a participação dos demais profissionais da educação no processo de tomada das decisões para melhoria das atividades pedagógicas e profissionais. O importante é fazer com que a administração escolar seja confiada, segundo Delors (2001, p. 163), a "profissionais qualificados, portadores de formação específica, sobretudo em matéria de gestão" escolar. E uma das condições fundamentais que a atividade escolar requer, além de envolver os professores na tomada das decisões atinentes à educação, é levar os professores a criarem o interesse pela qualificação, nos seus cargos, e a beneficiarem-se do apoio e trabalho coletivo dos demais profissionais da educação. Assim sendo, é fundamental para o trabalho pedagógico a

\footnotetext{
colaboração de especialistas exteriores a escola, ou experiências educativas extra-escolares; participação dos pais, segundo modalidades apropriadas, na gestão dos estabelecimentos de ensino ou na mobilização de recursos adicionais; ligação com associações para organizar contatos com o mundo do trabalho, saídas, atividades culturais ou desportivas ou outras atividades educativas sem ligação direta com o trabalho escolar (Delors, 2001, p. 165).
}

Uma das questões que não se poderia deixar de mencionar é a relação entre a formação do professor e a situação política de guerra, isto é, a visão que se procurou passar aos professores (e se reproduz, de alguma forma, no ensino), como forma de garantir a justificativa de seu estado (o pouco avanço no nível de formação), apontando a guerra, desligada de seus autores, e o colonialismo português como fatores determinantes desta situação. Ora, o empreendimento da guerra angolana se justificava, apenas, na medida em que os objetivos a serem alcançados visavam à liberdade política e cultural e à independência do país em relação aos portugueses - que foi a guerra 
empreendida antes de 1975, diferente daquela que se seguiu à independência, impedindo que uma formação mais eficaz de professores fosse possível.

Numa situação em que a luta se volta pura e simplesmente à obtenção de poder, as dificuldades em relação à formação de professores são maiores, pois se nota a ausência de políticas eficazes de ampliação dos espaços escolares e de cursos de níveis superiores para formação de professores. Sendo assim, espera-se que além de se apontar o número de professores (levantamento de dados sobre o corpo docente existente em Angola) que exercem a atividade de ensino sem condições, é fundamental dar-lhes os meios e a formação de que necessitam para o exercício de suas atividades de ensino, pois os alunos se sentem no direito de esperar dos profissionais da educação uma dedicação e atuação qualificada e responsável.

Para tal é fundamental, que alguns aspectos ligados à formação e atuação dos professores ${ }^{32}$ sejam observados: Reconhecer o trabalho do professor, isto é, valorizar o papel do professor e seu estatuto na sociedade angolana, pois com isso, se permite maior contribuição no progresso social, no esforço da compreensão mútua entre os angolanos, na criação e desenvolvimento do espírito crítico; Formação continuada, esta é fundamental na medida em que contribui para o aumento contínuo do nível acadêmico do professor, da sua competência e motivação e melhora o seu estatuto social. Além disso, a formação continuada permite a atualização dos conhecimentos, novas experiências e uso da tecnologia; Trabalho coletivo (metas pedagógicas de cada escola), em toda a vida profissional, cada vez mais, tem se tornado importante o trabalho em equipe. O trabalho do professor ainda que, em grande parte, pareça solitário, na medida em que cada um tem sua disciplina e seu programa, é indispensável a cooperação entre professores de diversas disciplinas para se tratar de temas mais abrangentes ligados diretamente ao quotidiano do aluno e aos problemas da sociedade.

Falar em formação de professores e sua qualificação continuada, durante o período de guerra, ainda assim é uma questão complexa, pois, ao interrogar-se quais as prioridades que cada um dos partidos políticos buscava nota-se que o desenvolvimento do ensino e a formação de quadros docentes não constituíam prioridade, até porque o estado de conflitos permitiu criar um novo discurso e prioridade política: o combate ao "inimigo". Como dizia Agostinho Neto (primeiro

${ }^{32}$ Também aponta a necessidade do reconhecimento do trabalho de professores o Relatório para a UNESCO da Comissão Internacional sobre educação para o século XXI que foi organizado por Jacques Delors, em um livro, sob o título de "Educação: um tesouro a descobrir", 2001, p. 152-166. 
presidente de Angola e do MPLA), no texto proferido no dia 11 de novembro de 1975, “os Órgãos do Estado na República Popular de Angola guiar-se-ão pelas diretrizes superiores do MPLA mantendo-se assegurada a primazia das estruturas do Movimento sobre as do Estado" (Documentos, 1975, p. 11-12).

O que se pretendia, tanto para um quanto para outros movimentos, era a obtenção e controle do poder no país. Para isso os discursos sempre apontaram numa direção de exclusão de qualquer pensamento diferente dentro dos movimentos. Esta mesma lógica de pensamento foi incutida, através do sistema de ensino, na formação dos professores para legitimar uma dada "verdade" em detrimento da outra. E quanto ao ensino, o texto proclamado declara que "as nossas escolas, a todos os níveis deverão sofrer uma remodelação radical para que possam de facto servir o povo e a reconstrução econômica" (Documentos, 1975, p. 14). Como qualquer outro discurso, a saída deste pensamento do papel está longe de ser uma realidade.

A estrutura do ensino geral primário $\left(1^{\mathrm{a}}\right.$. à $4^{\mathrm{a}}$. classe $)$ e secundário $\left(5^{\mathrm{a}}\right.$. à $6^{\mathrm{a}}$. classe), mesmo depois da independência, continuou limitada, não permitindo, aos professores que atuavam nas escolas e à população, caminhar para níveis mais elevados. O que de alguma forma levou a formação dos professores a limitar-se ao treinamento técnico-pedagógico em níveis não muito distantes daqueles em que eles lecionavam. Esta situação de formação limitada havia já começado na administração de ensino do então sistema político colonial, traçado em 1964. Dos professores que lecionavam podese, segundo Peterson (2003), considerar basicamente duas categorias nacionais:

\footnotetext{
a primeira, cuja maioria teve uma formação muito débil do ponto de vista científico e pedagógico, sendo composta por monitores escolares em via de desaparecimento por terem evoluído para níveis subseqüentes de acordo com os artigos $23^{\circ}$ e $25^{\circ}$ do Decreto-lei $n^{\circ} 45908$, de 1964; a segunda, constituída por professores de posto, professores dos cursos acelerados, professores dos cursos básicos, professores dos cursos de superação que desempenharam um papel paliativo no sistema educativo durante muito tempo (Peterson, 2003, p. 24).
}

Depois de 1975 foram tomadas algumas medidas que permitiriam dar uma resposta mais adequada ao índice elevado de analfabetismo que o país apresentava. Como forma de responder ao agravo educacional reinante no país, criou-se o decreto $n^{\circ}$. 
44/79 que permitia contratar os chamados professores colaboradores e com isto procurar dar respostas à expansão do ensino. Criou-se então a categoria de professores colaboradores. Segundo Peterson estes eram mobilizados:

\footnotetext{
a partir dos vários sectores da vida nacional para co-participarem nas tarefas do ensino, conforme o Decreto $n^{\circ} 44 / 79$, cujo comportamento pedagógico, pelo menos para alguns, é indesejável, pois, de modo geral, para além das suas aulas, por várias razões não participavam efectivamente nas tarefas escolares. Em 1979, foram recenseados cerca de vinte mil colaboradores docentes; em 1980/81 apenas mil oitocentos e sessenta e cinco estavam em exercício de funções (Ministério da Educação. "Situação actual da educação e ensino e medidas de emergência”. 1984. In: Peterson, 2003, p. 25).
}

A prática de ensino necessitava passar por uma reestruturação pedagógica e política. Esta medida não poderia limitar-se à simples divulgação ou ensino da leitura e escrita do português, mas abranger uma adequada formação de professores em primeiro lugar. Durante os últimos anos da colonização portuguesa (1960-1974), a formação de um monitor (conteúdo das disciplinas que constituíam sua grade curricular) com a idade mínima de 18 anos, segundo Peterson (2003), se limitava à 4 a . classe. Constava do seu currículo as seguintes disciplinas: Práticas Pedagógicas, Português, Portugalidade; Aritmética e Geometria; Primeiros Socorros; Formação Rural; Ciências Geográfico-naturais; Legislação; Canto e Formação Feminina. Os cursos de monitores de " $1^{\circ}$. ano preparavam professores para o pré-primário; os do $2^{\circ}$. ano, para a $1^{\mathrm{a}}$ classe; os do $3^{\mathrm{o}}$. ano, para a $2^{\mathrm{a}}$. classe; e os do $4^{\mathrm{o}}$. ano, para a $3^{\mathrm{a}}$. classe, num ambiente quase de simulação de aulas" (Peterson, 2003, p. 27).

A formação do professor com a habilitação literária ${ }^{33}$ de $4^{\mathrm{a}}$. classe estava submetida a um curso de quatro ou seis anos e tinha, segundo Peterson (2003), as seguintes disciplinas: Matemática; Ciências Geográfico-Naturais; Portugalidade; História de Portugal; Língua Portuguesa; Desenho e Trabalhos Manuais; Moral e Religião; Educação Física; Noções de Pedagogia e Didática; Prática de Didática; Prática de Agricultura e Pecuária; Actividades Sociais; Legislação Escolar; Formação Feminina; Higiene e Saúde Pública; Noções de Enfermagem e Primeiros Socorros; Puericultura (Peterson, 2003, p. 27-28). A ilustração destas disciplinas permite ter a

\footnotetext{
${ }^{33}$ Habilitação literária indica o nível (série) escolar ou nível acadêmico.
} 
noção do tipo de ensino que o país herdou e a formação que os professores tiveram, e por outro lado, a continuidade da influência deste ensino na estruturação do ensino depois de 1975.

Apresenta-se assim, segundo o Ministério da Educação (2004), aos dias atuais, o desafio de superar o quadro formativo de que resulta o corpo docente mediante o incentivo à formação continuada e responsabilidade pedagógica em Angola. Isso requer, desde o ensino primário, trabalhar para um ensino capaz de fornecer às crianças instrumentos necessários para a compreensão e crítica, e de favorecer a coesão social, estimular o rigor intelectual e melhorar as condições de trabalho do professor, pois entende-se que este só poderá atuar melhor na escola se possuir conhecimento, condições econômicas e espaço adequado de trabalho.

Conforme abordamos no primeiro capítulo, a questão da fome, pobreza, exclusão social e da presença de crianças nas ruas, resultado da guerra civil, precisa ser debatida numa perspectiva diferente (inclusão social), na formação de professores, pois já não se trata de questões externas ao ambiente escolar. Para tal, a formação dada aos professores necessita corresponder à essa situação posta pela guerra civil. Entendemos que

\footnotetext{
À medida em que a separação entre a sala de aula e o mundo exterior se torna menos rígida os professores devem também esforçar-se por prolongar o processo educativo para fora da instituição escolar, organizando experiências de aprendizagem praticadas no exterior e, em termos de conteúdos, estabelecendo ligação entre as matérias ensinadas e a vida quotidiana dos alunos (Delors, 2001, p. 154).
}

Cabe à sociedade do momento o trabalho de resolver situações que afetam a vida do país e de reconstruir os elementos indispensáveis à convivência social, à democracia participativa e ao ensino separado do espírito "modelador". Trata-se de criar atitudes fundamentadas em valores culturais e, a partir desses, orientar a vida em sociedade. Neste sentido, as reformas precisam basear-se na busca de consensos das finalidades do ensino e meios. A reforma não se concretiza contra ou sem professores comprometidos com o trabalho educativo e sem garantia de condições de trabalho.

Em suma, a formação de professores precisa ser repensada de maneira a cultivar nos próximos profissionais as "qualidades requeridas", isto é, formar 
intelectuais aptos a favorecerem uma nova perspectiva de ensino angolano, pois a atividade do professor requer, além do domínio de técnicas pedagógicas, também uma ampla formação teórica que pode permitir problematizar situações presentes na escola e, em geral, na sociedade angolana. Isso contribui, para o aluno, compreender as questões culturais, políticas e econômicas mais abrangentes; desenvolver sua autonomia e personalidade. Entendemos que a melhoria do sistema de ensino angolano passa também pelo aprimoramento de técnicas pedagógicas de supervisão, avaliação, gestão escolar e pela participação da comunidade no processo pedagógico.

\section{2 - Relações de poder disseminadas no meio educacional}

Conforme mencionamos no capítulo primeiro à medida que, depois do Acordo do Alvor, a guerra civil em Angola foi tomando dimensões institucionais e internacionais, ela aumentava sua intensidade. Isso afetou de forma geral as estruturas administrativas, gerando instabilidade das atividades políticas, desestabilização das infra-estruturas econômicas, sociais, culturais, educacionais e deslocamento contínuo das populações à procura de melhor lugar para sua segurança e sobrevivência. A guerra subia de patamar e a destruição também. Que espaço encontra o debate a respeito da educação neste meio de lutas? Que recursos são destinados ao sistema educacional? Encontra alguma prioridade a discussão sobre a melhoria de ensino, ampliação do número de vagas nas escolas e aumento das infra-estruturas escolares? As respostas tendem mais para o lado pessimista do que otimista.

São várias as questões que requerem entendimento para a abordagem da educação angolana e as repercussões da guerra no processo educacional. Não há dúvidas de que a guerra impediu, em grande parte, o avanço do sistema educacional, da infra-estrutura e da formação de professores. Importa, contudo, não se apontar apenas para a guerra "em si", como elemento desestruturador das relações sociais, do sistema educacional, das infra-estruturas e de outros aspectos fundamentais à vida em sociedade. É preciso antes entender as razões pelas quais a guerra predominou sobre as demais possibilidades que poderiam ser realizadas: a paz entre os angolanos, a democracia, o desenvolvimento socioeconômico, a liberdade política e a garantia dos direitos fundamentais como a educação, saúde, trabalho e moradia. 
Fundamental aspecto diz respeito, também, ao entendimento das justificativas que, como já foi mencionado no capítulo anterior, ao longo dos anos se procurou forjar no seio da sociedade angolana de forma a manter vivo o discurso, segundo o qual, apenas o fator guerra e colonial constituem elementos chaves para explicar o estado atual da educação no país sem, no entanto, mencionar-se os interesses dos seus autores, internos e externos, no que concerne ao controle do poder.

O discurso politicamente construído e impregnado na educação, com vistas a preservar o poder e submeter os demais aos interesses da minoria, perpassa o quotidiano do angolano, tanto ao mais velho como ao jovem da sociedade presente. No momento do alcance da independência (1975) notou-se que mesmo que o poder tenha mudado de mãos do colonizador para as do "Estado Nacional Independente", - sob a direção do MPLA-PT ${ }^{34}$ - as questões fundamentais atinentes à administração e governo do país entre os três movimentos políticos que combateram o colonialismo português não foram corrigidas, o que manteve a distorção socioeconômica acompanhada por um esforço de limitações impostas ao desenvolvimento democrático, liberdade e justiça social. Conforme dizia Manuel Jorge (1998), ao alcançar-se a independência;

\footnotetext{
O Partido todo-poderoso abateu-se como uma placa de chumbo sobre o conjunto do corpo social, a polícia política omnipresente e omnisciente perscruta todas as consciências, o direito de crítica foi batizado como 'agitação contra-revolucionária', o direito de publicação foi reservado apenas aos membros do partido e, para coroar tudo isto, o país viveu sob o regime de recolher obrigatório desde o próprio dia da proclamação da independência (Jorge, 1998, p. 82-83).
}

O texto da independência, proclamado pelo MPLA a zero hora do dia onze de novembro de 1975 , expressa a situação que durante muito tempo viria estar na base da luta contra os outros movimentos e afirma o único partido com direito de exercer o poder em Angola. Defendia ainda, neste mesmo texto, ser o único movimento que não violou os Acordos de Alvor assinado pelos três movimentos sob direção de

\footnotetext{
${ }^{34}$ Até o ano de 1990, este Partido chama-se: Movimento Popular de Libertação de Angola e Partido do Trabalho (MPLA-PT). Com a criação da Lei sobre o multipartidarismo e Acordo de Bicesse (Estoril), aos 31 de maio de 1991, para o fim da guerra entre a UNITA e o MPLA, sob a supervisão da ONU e que permitiu o lançamento do processo eleitoral para as eleições que viriam acontecer de 29 a 30 de setembro de 1992, o partido passou a denominar-se somente MPLA.
} 
Portugal e, em função disso declarava: “aos lacaios internos do imperialismo de há muito os deixamos de reconhecer como movimentos de libertação" ${ }^{35}$.

No entanto este movimento, como os outros dois, também recebia apoio externo para o treinamento de seus militares, apoio material e meios de combate assim como também defendia uma ideologia que não era originariamente própria mas sim assegurada, entre outros, pela URSS e por portugueses que como forma de assegurar sua permanência em Angola procuraram aliar-se ao MPLA. Dizia Kenneth Kaunda, numa mensagem de 19 de abril de 1975, em conversa com Kissinger, que o “incipiente conflito em Angola não era mais puramente endógeno. O MPLA não era simplesmente um grupo marxista, como a FRELIMO de Moçambique, mas uma ferramenta de Moscou" (Kissinger, 2001, p. 824).

Se por um lado era comum a idéia, segundo a qual, a independência só poderia ser alcançada mediante uma luta revolucionária contra o colonialismo português, e para isso estavam envolvidos os três movimentos, por outro percebia-se que esta mesma visão, em cada movimento, se transformava como em uma vontade própria, e portanto, sem necessidade de ligação e cooperação interna (entre os partidos ).

Ainda segundo o texto (documento) da proclamação da independência de Angola, acima citado, o alcance efetivo desta independência só seria vitorioso se fosse realizada "uma frente de unidade de todas as forças anti-imperialistas de Angola que não estivesse ligada à cor, à situação social, a credos religiosos e tendências individuais". Afirma o mesmo documento que "será vitoriosa graças à formação de um vasto Movimento Popular de Libertação de Angola” (Documentos, 1975, p. 10).

Salientar estes aspectos é importante na medida em que permitem entender o contexto em que fora estruturada a política educacional, pois enquanto elemento ou aparelho do Estado, a escola foi vista como aquele espaço em que, com ajuda dos meios de comunicação, se propaga a ideologia política do movimento dominante para garantir sua permanência no poder. E isto implicou na luta contra aquelas correntes políticas que apresentavam orientação política diferente.

Através do Ministério da Educação, o movimento no poder, estruturou uma forma de se entender a educação, inserindo nela elementos característicos de poder

\footnotetext{
${ }^{35}$ Cf. Documentos. Proclamação da Independência da República Popular de Angola. 11 de Novembro de 1975, p. 9.
} 
totalitário e de orientação "socialista". Cabia aos professores, na sua formação em 1979, compreender a educação como;

[...] a transmissão de conhecimentos, idéias, opiniões, crenças e costumes que influenciam o indivíduo e passam de geração em geração. [...] A educação na sua comunidade, mediante as suas instituições, como a família, a escola, as organizações políticas e de massas, utilizando os meios massivos de comunicação; como a rádio, o cinema, a televisão, a imprensa, dão forma ao indivíduo que o regime social necessita. A educação é a influência sistemática que com um sentido e um fim determinado, se exerce sobre a psicologia do educando para desenvolver nele as qualidades desejadas pelo educador ${ }^{36}$.

Percebe-se o aspecto coercitivo impregnado nesta citação. A influência que se trata consiste em fazer com que o jovem acredite em uma ideologia como verdade única, negando assim outras formas de pensamento e de organização social do país e do poder de Estado. De qualquer forma é necessário tê-la em consideração na discussão atual de educação caso queiramos primar, no atual sistema educacional, pela democracia, liberdade de expressão, cidadania e participação política.

$\mathrm{O}$ aspecto sinistro, presente nos discursos, da camuflagem do problema social permanece, mesmo estando num contexto (depois da guerra, em 2002) em que o debate sobre a democratização do Estado angolano poderia ser ou constituir aspecto fundamental da preocupação política dos dirigentes. Nas ações permanece a intolerância política, a negação, a segregação do diferente e daquele que não partilha da mesma linguagem do poder dominante.

Preocupante é também, por um lado, a inexistência de práticas sociais, - ou, quando se fazia, a sua destruição ou impedimento - e das individualidades somadas em decorrência de uma ordem que se impõe de cima para baixo sem, no entanto, haver clareza de onde emana tais poderes ou ordens e, por outro lado a origem do sentimento, tão arraigado nas consciências, da impossibilidade de engendrarmos, a partir de nós mesmos, uma política e uma educação democrática de qualidade para o país sem imitar "modelos" distantes da realidade sociocultural angolana. Entendemos que quando se trata do social e da educação o sentimento de luta deve ser de pertencer ao todo da

\footnotetext{
${ }^{36}$ Direção de formação de quadros de ensino. Curso de formação de professores: pedagogia. República Popular de Angola - Ministério da Educação. Luanda, 1979, p. 10-11.
} 
sociedade, integrar-se politicamente nas práticas sociais compartilhadas, o que significa a participação de todos na educação e bens públicos.

Os fatos políticos, históricos e educacionais surgem e se dão a partir das relações de lutas sociais e econômicas, por meio de interesses, de ideologias e de perspectivas culturais que a "sociedade" - ou um determinado grupo - acalenta atingir. Existem fatores, relativos a processos que se originam de um determinado sistema ou estrutura como o avanço para o desenvolvimento que, primariamente, são originados por impulsos de manutenção e superação. Por outro existem os fatores externos que influem sobre o organismo interno em contraste com efeitos que se originam do próprio organismo.

As desavenças políticas e as opções ideológico-partidárias se estabelecem dentro desta estrutura de fatos internos e externos, conforme os interesses da classe dirigente. A compreensão política e educacional de Angola requer, também, ter em mente estes dois lados dos fatores sobre os quais se delineou tal educação. É certo que o desentendimento entre os movimentos políticos desde a sua origem constituiu o principal obstáculo ao desenvolvimento da educação e política desta sociedade. Todavia, é importante notar que estes desentendimentos têm também, como pano de fundo, o interesse em atender à pressão externa, à expansão do capitalismo, por um lado, e do socialismo, por outro, que após a segunda Guerra Mundial e durante a Guerra Fria procuraram alargar, por outros países, suas visões acerca da organização política e econômica da sociedade.

É neste meio de lutas, por uma redefinição concreta do ensino, que Angola se encontrava, e ainda se encontra, para refletir sobre o direcionamento a que a educação deveria seguir, o que exigia uma metodologia para precisar seu andamento. E se assim não aconteceu a questão que se levanta é: será que a educação está ou foi se distanciando de seus fins primeiros, isto é, educação entendida como processo de desenvolvimento da capacidade moral, intelectual, crítica e física do ser humano? Será que faltaram parâmetros morais humanos e, em função disso, perdeu-se o rumo no engajamento de tomada de posições políticas para Angola? O desenvolvimento da educação está relacionado à política traçada pelo Estado, seu interesse em relação ao ensino e ao crescimento econômico do país. Uma vez que o interesse se volta para a obtenção e domínio do poder político e econômico sem, com isso, procurar estabelecer 
parâmetros de desenvolvimento político educacional ligado ao crescimento econômico, as relações sociais que se estabelecem poderão tender mais para a exclusão social.

O mal-estar que afetou o sistema educacional angolano, no qual se constata a necessidade urgente de repensá-lo, traduz uma "crise" que resulta do distanciamento do problema de ensino no espaço político onde o interesse individual ou de grupo pelo poder, em detrimento do social coletivo, foi preponderante. Contudo, ainda podemos interrogar-nos: diante dos fatos evidentes no país, resultantes de uma guerra, depois da independência (1975), será que a garantia dos direitos fundamentais à vida em sociedade se tornou, simplesmente, uma das páginas, no livro da história, sem solução e, portanto relegada ao segundo plano? Essa situação provém da "incapacidade" de criar e manter a condução de políticas públicas sociais e de ensino? De forma geral a luta pela melhoria de condições continua, por parte da população através das organizações não governamentais e dos grupos de lutas pelos direitos humanos, mas os interesses daqueles que detêm o Estado precisa também se voltar ao social. A ausência de medidas de desenvolvimento de política educacional ou de mecanismos para manter as medidas, representa ainda uma certa falta de compromisso social comparado à força com que se defende o poder e se apropria da economia.

Vale registrar que, dos partidos políticos vigentes, já mencionados no primeiro capítulo, nenhum está apto (sozinho), mesmo que o queira, a curto ou médio prazo, a reivindicar para si a totalidade das competências do Estado Nacional. Sendo assim, requer que haja um compromisso político, acima dos interesses de grupos ou partidos, que permita a viabilidade das questões sociais, administrativas e de infraestruturas degradadas durante a guerra. Também é vital a distinção entre as fundamentais funções particulares do Estado que de certo modo são contingentes, e por outro, aquelas funções que são gerais, que consistem em assegurar a integração populacional, coesão social e relações culturais.

A inserção (1976), por exemplo, nas escolas, de uma educação "cívica" que visava fazer acreditar que só poderia haver "uma verdade" e com isso negar outras formas de entender o mundo, não foi suficiente para apagar a imagem negativa forjada no quotidiano, nas relações concretas da repressividade, de impedimento da manifestação de liberdade ou de crítica, assim como não é suficiente para justificar a ausência do Estado na tomada de medidas claras em relação ao ensino 
público no país, isto é, a impotência deste perante a situação do desemprego, moradia, saneamento básico, saúde e ensino.

A luta pela revolução não significa apenas uma forma de conquista do poder, mas fundamentalmente, a transformação das estruturas sociais. Uma mudança qualitativa que permita, aos poucos, o desenvolvimento das estruturas econômicas, políticas e sociais da sociedade e, estas mudanças, a princípio poderiam ter sido feitas sem necessidade de recorrer às armas, uma vez que a primeira etapa de luta pela independência tinha sido alcançada. Segundo Corbisier (1978, p. 17), "se as revoluções são historicamente acompanhadas pela violência, é porque as classes e grupos dominantes, detentores da riqueza e dos privilégios, não abrem mão espontaneamente dessa riqueza e desses privilégios".

A situação de intolerância política produziu a destruição dos laços sociais e culturais, para obedecer-se a uma ordem estruturada, impedindo desta forma uma opção política diferente da estrutura de poder encarnada pelo regime ${ }^{37}$, resultando em conflitos pelo poder, revestidos de discursos muitas vezes insinuantes, sob um prisma ideológico fundado nas práticas de exclusão política. Segundo Raul Tati (1999, p. 65), isto resulta do fato de os líderes políticos, desde os primórdios da independência, empregarem-se a "maior parte do tempo em querelas e disputas pelo poder. Os nossos líderes políticos canalizaram esforços e recursos incalculáveis para a conquista e a conservação do poder, negligenciando as tarefas prioritárias do desenvolvimento" social, econômico, político e educacional. Esta tese é confirmada também por Abdoulaye Wade na obra intitulada "Un destin pour l'Afrique”, publicado em Paris em 1989.

A compreensão do sistema ideológico criado passa pela percepção da ordem impregnada nas ações políticas e sociais e por uma educação que permita maior clareza do problema da sociedade. Educação compreendida como instrumento de luta política por uma igualdade de direitos e responsabilidade. Assis Capamba, numa entrevista cedida à revista "Figuras e Negócios" de Agosto de 2004, quando se referia à

\footnotetext{
${ }^{37}$ A substituição do poder colonial pelo nacional angolano, muitas vezes, mais se parecia com o sistema neocolonialista do que de unidade política e cultural do país, sobretudo, pela forma como estes novos dirigentes herdaram e apropriaram-se da estrutura e métodos coloniais que eles mesmos combateram. A Luta pelo controle do poder, sem estratégias concretas de ação social para o país, e a ausência de projetos claros de democratização do país, que permitiriam maior participação e contribuição dos demais na resolução dos problemas sociais do país recém independente levaram a lutas, semeando rivalidades regionais que custaram a vida de milhares de angolanos.
} 
dependência dos partidos a um só partido no poder e à forma como o povo está sendo usado e manipulado para semear a discórdia e o caos no país, ele concluiu que este quadro político existente espelha a realidade do processo de reconciliação nacional, pois a "dependência econômica dos partidos políticos", que se constata em Angola, a “intolerância, clientelismo e a corrupção; a inacessibilidade dos partidos políticos em obter dados sobre a governação do país nas instituições públicas; acentuação do Partido Estado na governação do país; interpretação restritiva da legalidade" (Capamba, 2004, p. 18), assim como outros aspectos de ordem política, têm seu impacto no campo da educação e estão entrelaçados na ação educativa de professores que legitimam esta ou aquela ideologia partidária.

A educação constitui uma dessas questões que, permanentemente, requer ser adequada aos propósitos políticos e culturais em vista das mudanças constantes a que toda sociedade é sujeita. Por outro lado, ao adequá-la a uma dada política, importa também assumir um dado compromisso cultural com a sociedade atual e do futuro, na qual se pensa implementar tal educação visando determinados fins credíveis à condição humana. Necessariamente isto deve acontecer por que, como afirma Hannah Arendt (2000):

\footnotetext{
A educação é o ponto em que decidimos se amamos o mundo o bastante para assumirmos a responsabilidade por ele e, com tal gesto, salvá-lo da ruína que seria inevitável não fosse a renovação e a vinda dos novos e dos jovens. A educação é, também, onde decidimos se amamos nossas crianças o bastante para não expulsá-las de nosso mundo e abandoná-las a seus próprios recursos, e tampouco arrancar de suas mãos a oportunidade de empreender alguma coisa nova e imprevista para nós, preparando-as em vez disso com antecedência para a tarefa de renovar um mundo comum (Arendt, 2000, p. 247).
}

E isto implica maior responsabilidade política e social por parte do Estado, em garantir que a educação em prol do reconhecimento da dignidade humana permita ao homem angolano (depois da guerra, 2002), maior compreensão de sua condição de vida política, cultural e social.

Entendemos que a forma como é concebida ou se entende a educação - os princípios teóricos críticos e filosóficos que esta se propõe a responder - seja importante para o desenvolvimento, ou não, da sociedade. As ações decorrentes do meio 
social, as formas de determinações destas e a consciência construída sobre estas ações constituem um dado importante para o delineamento crítico do sistema educacional, isto é, para percebermos o sentido das ações educativas e termos clareza política destas ações. Desta análise de pensamento decorrem as formas de articulação do indivíduo social que aspira à liberdade das suas ações tendo em conta a presença e os direitos de outrem.

Educação, sociedade e política constituem elementos sobre os quais se procura fundamentar a formação social do homem, a percepção e construção da concepção de sua vida em sociedade. Sendo assim, a idéia de que o Estado deve garantir o direito à educação, saúde e trabalho passa pelo crivo político filosófico. Estamos diante de uma preocupação que se apresenta ao Estado como responsabilidade e não como ato de caridade. Como dizia Flavia Piovesan (2004, p. 26) "a idéia da não acionabilidade dos direitos sociais é meramente ideológica, e não científica. São eles autênticos e verdadeiros direitos fundamentais, acionáveis, exigíveis, e demandam séria e responsável observância". Com isso eles devem ser "reivindicados como direitos, e não como caridade, generosidade ou compaixão" do Estado em relação à sociedade.

A luta político militar (1976-2002) pelo controle da economia e poder talvez possa esclarecer a razão pela qual se fez proliferar tal educação, procurando manter a autoridade do Estado (partido único) que reivindicou para si o "direito de governar" a sociedade angolana, isto é, o monopólio da coerção, do uso da violência e do poder, procurando ignorar outra forma que pudesse implicar na superação deste pela incorporação política de opções partidárias diferentes na esfera administrativa do país.

Agora, sob a pressão de novas políticas partidárias e sob a necessidade de democratização do país, a política monopolizadora parece encontrar novas formas em que esta se pareça, na sua dissimulação - num discurso de democracia política e multipartidarismo -, viável aos olhos da sociedade. Porém, os fins não parecem claros quando nos deparamos com as ações governamentais vigentes nas políticas administrativas, na forma como se pensa e se articula a nova estrutura política e educacional do país. Portanto, o novo sistema educacional precisará romper os círculos que impedem, à nova geração, o desenvolvimento da capacidade de pensar, romper o círculo que desfigura a aprendizagem e desenvolvimento do espírito crítico e, finalmente, incentivar o desenvolvimento do espírito criativo, tecnológico, científico e o pensamento de uma nova convivência pacífica. 


\section{3 - Autonomia, liberdade e ordem no sistema educacional}

A autonomia da escola ${ }^{38}$ não escapa à ordem politicamente pretendida pelo Estado desde 1975, da centralidade do poder, das decisões econômicas e administrativas justamente por a escola ser o veículo de propagação da ordem e de legitimação do poder. $\mathrm{Na}$ escola se difunde o discurso do certo e errado. Com a escola procura-se estruturar e desestruturar o que não é favorável à ordem pretendida pelo Estado, a da sua permanência no poder. Desta forma, a escola não só é uma instituição que trabalha para a legitimação do poder do discurso do Estado, como também, ao criar seu próprio discurso - do letrado e do iletrado, do "inteligente" e do "não inteligente" exclui todos aqueles que não obedecem à ordem e ao poder "legitimamente" aceito verdadeiro.

Falar em ordem no país depois da independência implica falar também em caos gerado pelo colonialismo português e pelas desavenças políticas entre os movimentos partidários. Libertar o país do "caos" colonial para instalar-se uma certa ordem foi assim apresentado como uma ruptura necessária para a formação da nova consciência. Nossa preocupação, no momento atual, é a qualidade do entendimento e percepção com que se analisa a ordem impregnada nas coisas (ações do quotidiano), ou seja, o poder invisível que demanda esta ordem depois da independência de Angola. Segundo Bauman (1999) a

\footnotetext{
luta pela ordem não é a luta de uma definição contra outra, de uma maneira de articular a realidade contra uma proposta concorrente. É a luta da determinação contra a ambigüidade, da precisão semântica contra a ambivalência, da transparência contra a obscuridade, da clareza contra a confusão (Bauman, 1999, p. 14).
}

\footnotetext{
${ }^{38} \mathrm{O}$ direito de decidir o que deverá ou não ensinar parece-nos mais adequado ser tratado como uma autonomia voltada às formas de procedimentos - à maneira de dar aula - do que, propriamente, daquilo que deveria ou não ensinar (conteúdo das disciplinas). Isto porque a escola não é alheia à política vigente na sociedade. Seu conteúdo é estruturado mediante os interesses do Estado e de sua política de governo. As possibilidades de mudanças dão-se na luta de poder de decisão o que implica ter domínio minucioso das contradições que esta política de Estado traz, da forma a se auto-impor e, perceber a ordem de seu discurso. A partir daí se pode empreender pontos de análise que possibilitem à escola ter uma "autonomia" para o autogoverno. Mesmo assim não se livra definitivamente do poder do Estado, uma vez que este é que define o que deverá ser ensinado e o quanto deverá investir em educação.
} 
A ordem se constitui da positividade que luta contra a negatividade do caos. Sem caos não há ordem e vice-versa. Se antes da independência o caos a ser combatido consistia na luta contra o colonialismo, alcançada a independência, o caos a ser combatido passou a ser aquele que pensa diferente, aquele que não comunga da mesma visão política e não obedece à ordem estruturada de cima para baixo mesmo sendo, esta estrutura, demagógica e portanto, antidemocrática.

Aprender a viver e ser de acordo com o que a ordem do novo Estado exigia significou, em outras palavras, deixar de ser o que se é, ou pelo menos daquilo que se acredita certo, para ser e agir de acordo com o que a ordem do Estado exigia. Ora, ser o que se é, e ao mesmo tempo, ser o que a ordem quer é muito mais complexo. E passados quase trinta anos da independência, ainda assim, "não ser o que deveria ser é o pecado original e irredimível do presente" (Bauman, 1999, p. 19).

Com o surgimento da política do multipartidarismo, que possibilitou a realização das primeiras eleições em setembro de 1992, parece que a fragmentação das relações e das formas de estabelecimento da ordem nacional mudaram de rumo. Contudo, em uma sociedade que, constantemente, se desintegra pelos conflitos ideológicos e pelas disputas de "territórios políticos" em busca do capital econômico e do poder, mesmo estando nos discursos as discussões políticas da sociedade que se diz estar em paz com a economia de mercado e, portanto, vivendo em democracia, o rompimento com as práticas da segregação política e negação do diferente não acontece.

Em que consiste, então, a autonomia - no trabalho pedagógico, no pensamento e na crítica - uma vez que, por um lado, a nova ordem (multipartidarismo) exige que se formem indivíduos para uma Angola, de economia baseada no mercado, onde a disputa se dá entre os que possuem os meios necessários e, portanto, exclui aqueles que não os possuem, e por outro perpetua a ideologia do Partido/Estado e a centralidade do poder político administrativo? $\mathrm{Na}$ chamada sociedade do individualismo, parece-nos que, a autonomia que se pretende é aquela que se produz a partir da fragmentação dos poderes. Aquela que consiste, segundo Bauman (1999, p. 20), "primeiro e acima de tudo no direito de não olhar para além da cerca e de não ser olhado de fora da cerca. Autonomia é o direito de decidir quando manter os olhos abertos e quando fechá-los, o direito de separar, de discriminar, de descartar e aparar". 
Como haveríamos de nos integrar obrigatoriamente em um sistema ou ordem política fechado, num país com tanta diversidade cultural e lingüística e opções partidárias diferentes? O que vamos ser, uma vez que o que somos não convém à nova ordem da política econômica de mercado, de que não fazem parte aqueles que "perderam a guerra", os mutilados, as crianças que se encontram nas ruas e tantos outros excluídos? O estabelecimento da ordem transformou-se numa pura e simplesmente solucionabilidade de problemas não localizados e, portanto, sem representatividade de grande destaque, ou seja, não tem nenhuma repercussão nacional, uma vez que os limites das classes estão postulados e concretamente definidos. Desta forma, a ordem que se pretende consiste em fazer com que cada um permaneça no seu lugar. Isto permite-nos entender que, o que se deseja não é exatamente a autonomia, em termos de pensamento político educacional, mas sim o estabelecimento de um poder que mais se pareça com a autarquia, isto porque, segundo Bauman, a autarquia constitui um tipo de poder que muitos políticos desejam e como se sabe:

Ele atrapalha-se na ausência de autonomia, sem a qual nenhuma autarquia pode viver. Os poderes é que são fragmentados; o mundo, teimosamente, não o é. As pessoas permanecem multifuncionais e as palavras, polissêmicas. Ou melhor, as pessoas tornam-se multifuncionais por causa da fragmentação dos significados. A opacidade surge na outra ponta da batalha pela transparência. A confusão nasce da luta pela clareza. A contingência é descoberta no ponto em que muitos trabalhos fragmentados de determinação se encontram, se chocam e se entranham (Bauman, 1999, p. 21).

Falar em autonomia, ordem política e democracia nos vários cargos, instituições e na sociedade em geral é apenas uma ficção que os decretos e estatutos tornarão plausíveis. Em outras palavras, não há autonomia quando somos o que a ordem ideológica determina em função de um capital econômico defendido pela classe que detém o poder no Estado e pelos demais possuidores do capital.

Na Angola pós-guerra (2002) os problemas continuam surgindo, em termos sociais e educacionais, e esses são criados à medida que as soluções tomadas não respondem, no âmbito nacional, aos problemas que a sociedade apresenta e com isso, através das atividades “ordenadoras” ineficientes se geram novas áreas de caos. A luta pelo progresso tem consistido antes e, sobretudo, na obsolescência das soluções de 
ontem. Torna-se fundamental entender por que, segundo Bauman (1999, p. 22), a "anormalidade é o outro lado da norma, o desvio é o outro do cumprimento da lei, a doença, o outro da saúde, a barbárie, o outro da civilização”. Um lado depende do outro, todavia esta dependência de um pelo outro não é simétrica, pois, afirma Bauman (1999, p. 23), o "segundo lado depende do primeiro para o seu planejado e forçado isolamento. O primeiro depende do segundo para a sua auto-afirmação”.

Está presente, no trabalho educacional do professor, o poder do discurso delineado pelo Estado, da necessidade do ensino que deve responder às exigências da sociedade, à política econômica de mercado e seu "desenvolvimento". Que a formação é importante na vida das pessoas, não temos dúvidas, uma vez que, por exemplo, quando se pergunta às pessoas o que é necessário fazer para se conseguir um "bom emprego", atualmente, elas respondem imediatamente que é necessário estudar e, quando alguém que estudou não consegue emprego (de acordo com o discurso vigente em Angola), é porque teve "mau ensino" e, portanto sem "qualidade".

Justifica-se assim a idéia de que a escola deve desenvolver nos seus alunos as habilidades que o mercado procura para não os deixar fora do mercado de trabalho! Todavia, é imprescindível compreender o mecanismo que se usa para fazer com que os formados, mesmo que competentes, não cheguem a postos de comando, justamente porque não se chega por concurso público ou por eleições, mas por via de relações internas de indicação e outras não viáveis a um sistema político de democracia.

Para manter-se vivo o discurso da necessidade de que precisamos "aprender a ser", de acordo com as exigências da "nova" sociedade angolana regida pela economia de mercado (a partir de 2002), que estimula o consumo e acumulação do capital sem responsabilidade social, estabeleceu-se um processo disciplinador, no qual as verdades a serem ditas são selecionadas e instituídas em virtude de um princípio de "coerência", seguido sistematicamente em vista do poder a ser mantido, para dar continuidade ao funcionamento do sistema que começou depois da independência (1975). O poder a que nos referimos "não é uma instituição e nem uma estrutura, não é uma certa potência de que alguns sejam dotados: é o nome dado a uma situação estratégica complexa numa sociedade determinada" (Foucault, 1985, p. 89).

Aspecto contraditório é notar que por um lado, nos discursos oficiais, está presente a idéia da necessidade de um ensino qualificado para a superação das calamidades que enfermam o sistema educacional e o nível de vida social das pessoas, 
mas, por outro lado, nota-se que o poder da necessidade de um ensino qualificado visa apenas salvaguardar a ordem que está presente em vários pontos a partir dos quais se estabelecem e se desenvolvem relações "desiguais e móveis" para atender a objetivos políticos pretendidos. A aplicação da estratégia adotada depende das relações estabelecidas e estruturadas politicamente na sociedade.

Urge perceber a ordem que predomina no seio político - da exclusão eletiva, da interdição, da separação e rejeição e da padronização do discurso. Enquanto, por um lado, se criam necessidades que devem ser superadas pela educação, por outro, se faz com que as pessoas que não conseguem atingir este ou aquele nível de ensino se conformem com o seu estado de "insucesso". Percebe-se a existência de uma certa tendência, na classe dominante, de querer tirar o Estado do foco da discussão da responsabilidade pela garantia do direito ao ensino, saúde e trabalho digno. Isso levaria cada indivíduo a responder pelo "seu" fracasso ou insucesso na vida social, como se tudo estivesse ao alcance de todos e como se a guerra realizada, depois da independência, partisse de uma "vontade coletiva" da população.

Outro aspecto presente na forma do exercício do poder do discurso é a coerção. Como afirma Foucault (2004, p. 35) "é sempre possível dizer o verdadeiro no espaço de uma exterioridade selvagem; mas não nos encontramos no verdadeiro senão obedecendo às regras de uma 'política' discursiva que devemos reativar em cada um de nossos discursos". Produz-se o discurso através da disciplina estabelecida, e esta fixa os limites de sua atuação de maneira que continuamente reatualize suas regras. Encontramo-nos dentro do sistema ou do discurso, mas isso não significa que podemos falar de tudo, ou que toda a verdade não institucionalizada pode vir à tona. Isto acontece porque, segundo Foucault (2004)

\footnotetext{
sabe-se bem que não se tem o direito de dizer tudo, que não se pode falar de tudo em qualquer circunstância, que qualquer um, enfim, não pode falar de qualquer coisa. Tabu do objeto, ritual da circunstância, direito privilegiado ou exclusivo do sujeito que fala: temos aí o jogo de três tipos de interdições que se cruzam, se reforçam ou se compensam, formando uma grade complexa que não cessa de se modificar (Foucault, 2004, p. 9).
}

A complexidade está sempre presente devido a modificações constantes das formas que o discurso toma, dependendo da circunstância ou da política 
que se pretende implementar e do fim último desejado pela classe decisória. A complexidade com que as coisas se apresentam está cerrada num sistema em que não se pode interferir de qualquer maneira. As idéias e as necessidades são criadas nas relações que se estabelecem no social e na política de desenvolvimento constante para a acumulação do capital. É preciso saber que a preocupação, em querer tornar inteligível o processo educacional, é porque "a educação é justamente essa atitude de forçar o homem a galgar píncaros sempre mais altos" (Teixeira, 2003, p. 65). A educação pode assim permitir ao homem assumir a coragem de recusa à construção da ideologia que o transforma em mera peça na engrenagem do poder reinante.

Pensar criticamente ${ }^{39}$, decidir de forma consciente em que discurso se deverá acreditar, saber julgar proposições, argumentos e opiniões, aferindo até que ponto podem ser críveis as análises dos argumentos usados para justificar a situação de Angola, constituem o complexo desafio a ser trabalhado pela educação da sociedade atual como forma de redimensionar nossa condição humana.

O discurso que é necessário conhecer não é simplesmente aquele que se manifesta ou aquele que, de qualquer forma, oculta o que se deseja, pois ele é também, segundo Foucault (2004, p. 10) “aquilo que é o objeto do desejo [...] o discurso não é simplesmente aquilo que traduz as lutas ou os sistemas de dominação, mas aquilo por que, pelo que se luta, o poder do qual nos queremos apoderar". Na forma de exclusão, como dizia Foucault, encontra-se o discurso da segregação da vontade de verdade: o proibido de ser dito.

Sendo assim, entendemos que a educação atual poderia fundamentarse sobre uma base científica sólida que procurasse, mediante investigações, esclarecer os aspectos sociais, históricos, políticos e culturais que fluem na atual sociedade angolana perspectivando, com isso, o entendimento e melhoria da convivência social. E este é um trabalho que requer o desenvolvimento da vontade de verdade mesmo sendo, a verdade, de que menos se fala. E isso manifesta-se como se para a sociedade atual

a vontade de verdade e suas peripécias fossem mascaradas pela própria verdade em seu desenrolar necessário. E a razão disso é, talvez, esta: é que se o discurso verdadeiro não é mais, com efeito, [...] aquele que responde ao desejo

\footnotetext{
${ }^{39}$ No contexto de Angola, talvez, a principal vantagem que o desenvolvimento do pensamento crítico possa proporcionar é evitar que as pessoas sejam manipuladas pela grande quantidade de informações, muitas vezes confusas e contraditórias, que diariamente os meios de comunicação colocam à disposição da sociedade.
} 
ou aquele que exerce o poder, na vontade de verdade, na vontade de dizer esse discurso verdadeiro, o que está em jogo, se não o desejo e o poder? O discurso verdadeiro, que a necessidade de sua forma liberta do desejo e liberta do poder, não pode reconhecer a vontade de verdade que o atravessa; e a vontade de verdade, essa que se impõe a nós há bastante tempo, é tal que a verdade que ela quer não pode deixar de mascará-la (Foucault, 2004, p. 19-20).

E ainda assim, aos olhos da atual sociedade aparece somente aquela verdade que não destrói e nem desestabilizaria a ordem, isto é, aquela verdade que fecunda a manutenção e a continuidade do poder que ao longo do tempo se foi legitimando. Ignora-se que grande parte da sociedade tem a vontade de verdade como "prodigiosa maquinaria destinada a excluir todos aqueles que, ponto por ponto, em nossa história, procuraram contornar essa vontade de verdade e recolocá-la em questão contra a verdade", nos espaços em que a "verdade assume a tarefa de justificar a interdição" (Foucault, 2004, p. 20). Depreende-se então a preocupação em entender os muitos caminhos que conduziram às relações presentes para perspectivar-se um futuro de solidariedade, justiça social e de aceitação em vez de interdição.

As resistências mesmo que reduzidas são importantes à medida que, ao se disseminarem no tempo e no espaço social e político, provocam rupturas e mudanças de comportamento. Nas mudanças e contradições da ordem, do discurso e da política econômica, encontram-se as brechas que podem permitir o entendimento do sistema e, consequientemente, a ruptura para a construção de novas "utopias possíveis". O principal trabalho do intelectual será, assim, procurar decifrar os vários mecanismos e formas em que o poder se dá, partindo de "uma estratégia imanente às relações de força" (Foucault, 1985, p. 92) de luta e de poder para tornar inteligíveis situações concretas, que levariam a mudanças no sistema de educação e de seus propósitos políticos.

O trabalho educativo tornou-se, assim, tarefa difícil neste sistema de ordem e poder devido à complexidade com que os discursos se estruturam e reestruturam de tempo em tempo. Busca-se a disposição conveniente dos meios para se obter os fins pretendidos pelos formuladores do discurso, de que as pessoas devem aprender e formarem-se mediante as novas concepções de necessidades da sociedade, da economia e mercado de trabalho. Esta necessidade é construída e sustentada por um discurso pautado num poder que se legitima na medida em que se aceita ser 
"necessário" a existência de uma ordem para a convivência nacional. Desta forma se produz o que se quer e mantém-se vivo o discurso da necessidade de um poder legitimado. O problema a ser combatido é o da desordem, por que esta cria um desconforto agudo e faz-nos sentir incapazes de apreender adequadamente situações de vida e optar entre ações alternativas que, no momento, se apresentam de formas variadas.

Se por um lado há o processo de estabelecimento da ordem, por outro, efetuam-se classificações das coisas disponíveis, das ações e relacionamentos políticos, sociais e, por que não, da própria educação! Discute-se assim, o que deve ser e o que não deve ser permitido pela educação; o prioritário e o não prioritário na sociedade atual. Segundo Bauman, classificar significa também separar e segregar.

\footnotetext{
Significa primeiro postular que o mundo consiste em entidades discretas e distintas; depois, que cada entidade tem um grupo de entidades similares ou próximas ao qual pertence e com as quais conjuntamente se opõe a algumas outras entidades; e por fim tornar real o que se postula, relacionando padrões diferenciais de ação a diferentes classes de entidades (Bauman, 1999, p. 9).
}

A preocupação em formar ou ensinar as pessoas a comportarem-se de acordo com o sistema instalado pelo regime no poder, depois da independência, também significou, em outras palavras, procurar uma forma de colocar as pessoas numa ordem estrutural e, com isso, poder manipular suas probabilidades de ação ou, mais concretamente, impedir qualquer tipo de revolta por parte da população. Significou, levar as pessoas a comportarem-se como se os eventos (guerra) não fossem resultado da vontade de defesa e permanência no poder, da apropriação dos bens públicos, destituindo as demais pessoas da possibilidade de reclamarem a sua participação na decisões do país e o beneficio advindo dos bens públicos. E não sendo fruto da vontade, mas sim do contexto em que se vivia depois da independência, o que as pessoas deveriam fazer seria, ao menos, limitarem-se à prevenirem-se da casualidade, mas assumindo a condição que a natureza destinou-lhes: permanecer na subordinação.

Com a proclamação da independência, a apropriação do poder e a instalação de novos mecanismos de domínio dá-se a grande inversão na ação política, isto é, de ação comum que visava o bem de todos passou-se à ação monopolizadora, por 
parte dos dirigentes, fazendo seus interesses particulares predominarem sobre as demais preocupações da população.

A partir da nova realidade que Angola viria a conhecer logo depois de 1975, seus dirigentes procuraram definir a nova tarefa da qual iria ocupar-se a educação, isto é, esforçarem-se em sustentar a legitimidade de seu poder (mediante uma estruturação constante do social e da forma de se ver as coisas) e manter a ordem negando ou suprimindo qualquer idéia que constituísse motivo de abalo ou desequilíbrio deste sistema de ordem e poder. Ora, conforme dizia Bauman (1999) sabemos que ordem e desordem caminham juntas numa luta de negação de um pelo outro; da estruturação de um e desestruturação de outro, e vice-versa. A pretensão de uma ordem nacional não é nada mais que pretender ter certeza do cálculo dos fatos, de certas situações imprevisíveis ou então, ao menos, diminuir a probabilidade dos imprevistos. Segundo Bauman (1999, p. 10) "por causa da nossa capacidade de aprender/memorizar, temos um profundo interesse em manter a ordem do mundo. A ambivalência confunde o cálculo dos eventos e a relevância dos padrões de ação memorizados". A contradição impregnada na ação, isto é, a ambivalência, faz o homem sentir-se indeciso e, com isso, ele passa a ver as coisas como irresolúveis e, portanto, teme a perda de controle.

Chegou-se ao momento em que as conseqüências da guerra empreendida tornaram-se imprevisíveis, isto porque, à medida que se pensava, supostamente, que se estava livre do retorno do indesejado e, portanto, do controle total do poder, aparece um novo contexto, de multipartidarismo, em 1992, que exige a realização de eleições e, portanto mudanças nos postos de poder, na constituição e nas regras de convivência. O novo contexto histórico político também exigiu dos estruturadores da ordem e do discurso uma mudança política e ideológica por força da vontade de verdade que durante muitos anos procurou-se negar. A democratização de Angola e a descentralização do poder administrativo constituem assim, na atual conjuntura política, outro grande desafio. O mesmo vale para o sistema administrativo nacional de ensino.

A situação que se proliferou no país logo depois de 1975 permite-nos perceber que a defesa da educação em massa, que em grande parte se limitou no primeiro nível, em finais da década de 70 e início de 80 , foi necessária na medida em que se precisava estabelecer uma suposta disciplina ou comportamento a partir da nova 
geração, uma formação que tornasse possível a legitimidade do poder e, portanto, a sujeição dos demais a este sistema de poder.

A saída deste sistema político instalado durante os anos de guerra passa, atualmente, pelo reconhecimento de que é fundamental o alcance da maturidade intelectual através de um sistema de ensino de qualidade, em todos os níveis, por parte da população, para livrar-se do sistema de autoridade imposta fundada na lógica de negação, segregação das demais pessoas e línguas de que o país é formado.

Sabe-se que a educação é um dos campos em que o discurso da ordem ganha legitimidade, perpetuando desta forma as contradições exclusão/inclusão, direito/privilégio, educação para todos/educação para uns. Ao mesmo tempo em que se classifica, também se exclui ou inclui, dependendo do ponto norteador do discurso legitimado. Surgiram entidades que procuram responder às questões sociais colocadas pela situação de que o país foi vítima, mas também surgiram aquelas que se fecham a outras. Umas são aceitas porque economicamente convêm ao sistema, outras são excluídas porque ou não são favoráveis ao sistema (defensores dos direitos humanos, da transparência na administração dos bens públicos, etc.) ou seus recursos não são de interesse ao sistema ou porque simplesmente precisam de ajuda e não têm recursos que possam ser de interesse do capital desejado e, portanto, sua presença significa gastos.

Em suma, a técnica do exercício do poder se dava não apenas na comunicação entre aqueles que possuem e os que estão privados dos meios, mas também através da escola, onde os professores tinham como instrumento de exercício do poder a vigilância, o exame e a avaliação. A forma de exercer esta hierarquia representava assim uma técnica a ser aperfeiçoada pelos chamados inspetores das escolas. Nisso educar significou sujeitar, pois desta forma se extraía a verdade dos alunos ou se provocava a ação que se pretendia, dependendo das relações de poder. 


\section{CAPÍTULO III}

\section{PRIMEIRA REFORMA DO SISTEMA EDUCACIONAL (1976- 2000): ORGANIZAÇÃO E ABRANGÊNCIA}

Analisar a organização do sistema educacional (depois de 1975), o seu desenvolvimento e abrangência constitui o ponto principal, no qual pretendemos nos deter neste terceiro capítulo. Todavia, também é fundamental apresentarmos algumas reflexões que nos permitam compreender as medidas educacionais tomadas e a prioridade que estas tiveram, em termos de políticas públicas, nas decisões do Estado, isto é, do investimento financeiro no setor educacional para atender ao desenvolvimento cultural, econômico e político de Angola. Entre outras medidas tomadas destacam-se o rompimento com a cultura colonialista, o desenvolvimento de um sistema educacional voltado à valorização da cultura nacional, o desenvolvimento das ciências e técnicas nacionais, o desenvolvimento da democracia política e da justiça social, a reforma agrária, visando maior integração social e produtividade, o estabelecimento da unidade nacional e africana (vide Anexo 3).

A organização do sistema educacional (1976) partiu da necessidade de mudança do sistema de educação que Angola herdou do colonialismo português classificado como ineficiente, limitado e, em termos culturais, mais voltado ao domínio cultural de Portugal. O sistema educacional português exaltava seus valores em detrimento dos valores nativos de Angola. Averiguando os manuais usados nas escolas, até a década de 1960 e finais de 70, ainda é possível notar a presença da ideologia de domínio colonial.

E isso representou uma grande dificuldade no momento da reorganização do sistema educacional (1976), pois os professores de que Angola dispunha para a sua educação eram frutos da educação colonial. Outra grande dificuldade provinha da falta de meios materiais suficientes para a produção de novos manuais de ensino, material didático suficiente para o país, assim como de um programa 
eficiente para a formação dos novos professores, que pudessem colocar em prática as medidas traçadas com o objetivo de serem implementadas em Angola.

Nos anos anteriores à independência (1960-1974) Angola havia travado uma luta pela defesa dos direitos de liberdade, autonomia política e independência em relação às autoridades portuguesas que se encontravam, nesta fase, sob o regime de Salazar (regime que procurou, a todo custo, injetar no país angolano a guerra e o terror contra todo aquele que, de alguma forma, tentava desobedecer às ordens portuguesas colonialistas).

Depois de 1975 além da dificuldade apontada, na área de educação, outros problemas, já mencionados no primeiro capítulo, gerados pelo sistema político anterior, também se fizeram presentes, tais como: o desacordo entre os movimentos políticos de Angola (MPLA, UNITA e FNLA), em parte gerado por Portugal para permitir o desequilíbrio entre estes movimentos e assim manter maior domínio sobre a colônia; a disputa de outros países em defesa de seus próprios interesses econômicos (exploração do petróleo, minérios, ferro, etc.), uns através de apoio ao movimento de luta nacional, outros através de alianças feitas com Portugal; a falta de unidade entre os dirigentes de movimentos nacionais e de compromisso com a paz em Angola.

As disputas políticas pelo poder, desencadeadas depois de 1975, entre os movimentos, com o incentivo externo, permite-nos pensar que a preocupação da luta estava centrada na ascensão ao poder político e no controle da economia, pois não foram medidas as conseqüências dos meios utilizados para que tal ambição fosse realizada. O compromisso e responsabilidade política com a paz, democracia e bem estar social, sobretudo durante os anos de 1993 a 2002, foi relegado ao segundo plano, justamente porque nenhum dos movimentos queria "abrir mão" de suas ambições particulares, pelo diálogo, para pôr fim à guerra armada.

O sistema de guerra permitiu a destruição das poucas infra-estruturas herdadas do governo colonial. Problemas de acesso limitado ao ensino básico, baixa qualidade do ensino, não efetivação do projeto de ampliação dos espaços escolares, etc. conquistaram maior espaço à medida que a guerra se proliferava no país, tomando conta da vida da sociedade.

No período em que Angola era tratada como uma colônia (século XIX), raramente os colonizadores mostravam-se preocupados com a formação ou educação dos nativos, pois a preocupação principal do colonizador estava, certamente, 
voltada para a exploração da força de trabalho e, para isso procurava, através dos mecanismos de restrições e ampliação do trabalho forçado, impedir tentativas de organização de ensino formal. Todavia, tal política não conseguiu impedir que a educação não formal fizesse parte do quotidiano do povo angolano. A luta de resistência aos valores do colonizador e a emancipação (independência) é um exemplo.

É no início do século XX que começam a aparecer os primeiros sinais de preocupação, por parte do Governo Português, de regulamentar um ensino oficial, diferente daquele que era dado por instituições religiosas, voltado especificamente para os negros. Um estudo que trata do ensino em Angola (colônia), de Gastão Souza Dias, na altura professor do Liceu da Huila (1934), mostra em seus gráficos, em termos de frequiência, a situação das escolas primárias, por exemplo, nos distritos da Huíla e Mossamedes, na matricula de 25 de dezembro de 1933: do total de 1.490 alunos matrículados, 1.125 eram brancos africanos, 104 brancos europeus, 234 mestiços e 27 negros (Dias, 1934).

O chamado ensino rural para indígenas, que em Moçambique funcionou desde 1930 com o nome de ensino rudimentar, foi criado em Angola pelo “Diploma Legislativo n. . 518, de 16 de abril de 1927”, o qual reconhecia a necessidade de o Estado português criar um sistema de ensino em Angola voltado aos negros. A finalidade deste tipo de ensino seria "divulgar entre o gentio a língua portuguesa, bem como criar entre as crianças indígenas hábitos de higiene, de compostura e de trabalho, predispondo-as a receberem facilmente os benefícios da civilização" (Dias, 1934, p. 28).

Até 1933 funcionavam em Angola vinte (20) escolas rurais, nas quais lecionavam professores indígenas e outros mestiços. Gastão S. Dias defendia a necessidade de recrutar maior número de professores entre os indígenas da província (Angola) e assegurar a formação destes professores através de uma escola, a ser construída, de professores de ensino elementar destinada principalmente aos indígenas. Todavia, esta idéia "se afigurava como errônea" (Dias, 1934, p. 28) para algumas autoridades portuguesas, que não concordavam que se formassem "mestres negros" (ou indígenas) para instruírem outros negros.

Funcionavam, até o ano de 1934, na colônia (Angola) “69 escolas primárias com uma freqüência total, aproximada, de 4.500 alunos", dos quais menos de $5 \%$ eram negros. Havia em toda "colônia três inspectores do ensino primário, cento e nove professores e professoras diplomados, cinco professoras ajudantes e três 
professoras do ensino infantil" (Dias 1934, p. 21). Foi regulamentado também, através do "Decreto do Alto Comissariado, n. ${ }^{\circ}$ 242, de 22 de fevereiro de 1922" (Dias, 1934, p. 24) o ensino profissional destinado aos indígenas. O decreto apontava este tipo de ensino como uma "necessidade inadiável". E de acordo com o art. 2 do mesmo decreto:

\begin{abstract}
O objetivo das escolas-oficinas é prover ao aperfeiçoamento e moralização dos hábitos e carácter das populações indígenas, disseminando o ensino de profissões manuais, de educação moral e da língua portuguesa, como necessárias e graduais etapas do seu progresso para uma civilização mais perfeita (Dias, 1934, p. 24-25).
\end{abstract}

Os argumentos em relação a este tipo de ensino profissional destinado aos indígenas são de que os benefícios que tais escolas poderiam fornecer são grandes e importantes ao trabalho da colônia. Segundo o Gatão S. Dias (1934),

A transformação por elas operada sobre o gentio, roubando-o à inferioridade da senzala, vestindo-o, fazendo dele um artífice meticuloso, incutindo-lhe, pelo exemplo, hábitos de asseio, levando-o a preferir à cubata a casa construída pelas suas próprias mãos, abrindo-lhe a inteligência pela freqüência da escola, moralizando-o pelo sentimento da família, deve constituir um dos motivos de orgulho da nossa acção civilizadora (Dias, 1934, p. 25).

E quanto aos professores que deveriam trabalhar nessas escolasoficinas o autor defendia o seguinte:

se em todos os gêneros de ensino a escola vale o que vale o seu professor, neste caso o aforismo toma um significado muito particular; e por isso a escola tem de ser aqui o único processo de recrutamento do professorado. $\mathrm{O}$ professor das escolas-oficinas deve possuir especiais qualidades de ponderação e de bondade, espírito de justiça e simpatia comunicativa, virtudes que imediatamente gerarão na alma simples do negro um sentimento de respeito e subordinação, sem o qual as escolas dificilmente poderão progredir (Dias, 1934, p. 25). 
As citações acima colocadas, de Gastão S. Dias, permitem-nos entender o tipo de mentalidade desenvolvido em Angola através da educação, da qual Angola herdaria seus professores assim como seus dirigentes, que também são frutos desta educação colonial. O rompimento com a cultura portuguesa não se dá, num primeiro momento, de uma maneira radical, uma vez que, na forma em que foi organizado o novo sistema de ensino, a estrutura política e a organização administrativa do país estão presentes elementos típicos da colonização: a subordinação, "centralidade" do poder político, a discriminação não de "raças" (fruto de uma construção histórica de domínio) mas sim de raízes (do assimilado espiritualmente em relação ao nãoassimilado), a permanência da visão humanista vertical tipicamente européia, na qual a classificação se dá por ordem de valores em detrimento da visão humanista africana horizontal $^{40}$ formada pela diversidade cultural e lingüística.

Além desta situação apontada acima, há por outro que considerarmos o desafio que o novo governo, agora angolano, haveria de enfrentar, isto é, criar a partir de 1976 políticas concretas que pudessem permitir a correção dos altos índices de analfabetismo apresentados pelo país ${ }^{41}$, ocasionados pela escassez do material básico de ensino, falta de professores, pouca abrangência do sistema educacional, etc. Havia também a necessidade de rever-se os conteúdos a serem ensinados e desenvolvidos no país independente, rever a formação do quadro docente e erguer novas infra-estruturas escolares.

Em vista desta situação foi elaborado o chamado Plano Nacional de Ação para a Educação de Todos. A preocupação principal deste plano era apresentar uma resposta ao problema da alfabetização de crianças e adultos, procurar, aos poucos, aumentar os espaços escolares de ensino, desenvolver a formação e aperfeiçoamento constante dos professores para permitir a expansão do ensino básico. Aprovado em 1977, o Plano Nacional de Ação para a Educação de Todos visava fundamentalmente ampliar a oportunidade de acesso à educação fundamental - sobretudo aos primeiros quatro anos de ensino ( $\left(1^{\mathrm{a}}\right.$. a $4^{\mathrm{a}}$. classe - gratuito).

Houve a cooperação de outros países, como Cuba, que enviava para Angola professores e estagiários para lecionarem nas escolas, principalmente no ensino

\footnotetext{
${ }^{40}$ Maiores detalhes da abordagem sobre o humanismo vertical europeu e o humanismo horizontal, africano podem ser encontrados na obra de Du Bois, Willian Edward Burghardt. As almas da gente negra. Traduzida por Heloisa T. Gomes. RJ, 1999. E também, de forma geral, tem considerável contribuição neste debate a obra de Appiah, Kwame Anthony. Na casa de meu pai. RJ, 1997.

${ }^{41}$ Calculava-se em $85 \%$ o índice de analfabetismo no final da colonização portuguesa - 1975 .
} 
fundamental, médio e superior, devido à falta de professores angolanos suficientes para atender a estes níveis de ensino, e também em cursos de formação de professores angolanos. Segundo Teresa J. A. da Silva Neto, em sua tese de doutorado defendida em 2005 na Unicamp, "uma das peculiaridades técnicas desta cooperação se acentuava na facilidade de adaptação do ensino ministrado por esses professores às condições sociais de Angola, até adaptando e improvisando carteiras para que os professores não ficassem sem aulas, por falta deste recurso material" (Silva Neto, 2005, p. 157). Porém não podemos esquecer que a ligação ou cooperação com os professores cubanos devia-se, também, a uma questão política e ideológica de países alinhados. Angola estava neste momento sob sistema e governo de um partido que se auto-afirmava socialista e defensor dos princípios desta política.

A defesa do socialismo, por parte do partido no poder, permitiu que fosse possível uma aproximação com Cuba, União Soviética (URSS), Hungria, Bulgária, países do antigo Leste Europeu e outros que se encontravam sob este regime político, depois da segunda guerra mundial. É importante analisar o porquê da ligação de "Angola" (MPLA) a estes países, da UNITA à África do Sul e aos EUA, e da FNLA à China e ao Zaire (atual República Democrática do Congo - RDC) para perceber-se o interesse que estava por detrás destas ajudas ou apoios dados aos movimentos políticos angolanos. Não se tratava apenas de uma ajuda ao país recém independente, mas também e, sobretudo, do alastramento estratégico e ideológico dos princípios defendidos por cada uma das partes (do bloco socialista e capitalista), envolvidas na guerra fria.

Angola tornara-se um espaço onde as lutas pelos interesses se entrecruzavam, desde o interesse puramente econômico ao domínio do poder político. A política que cada um dos movimentos empreendeu em Angola, depois da independência, permite-nos compreender o quanto se diferenciava da ideologia do socialismo (defendido pelo MPLA) ou da democracia ou ainda do capitalismo (pela UNITA e FNLA), que esses movimentos diziam defender, uma vez que nada tinham de "profundidade" política que pudesse identificá-los com estas ideologias.

Além dos professores cubanos que se deslocavam para Angola com intuito de atuarem nos diversos níveis de ensino havia também a possibilidade de os jovens angolanos se formarem no sistema educacional cubano. Estes iam, através das bolsas de estudo cedidas pelo governo cubano, para as mais variadas áreas do 
conhecimento, na ilha da Juventude de Cuba. Segundo Silva Neto (2005, p. 157) “estima-se que Angola, em 1978, recebeu de Cuba 951 bolsas de estudos e 1200 crianças e adolescentes do primeiro grau ( $5^{\mathrm{a}}$. e $6^{\mathrm{a}}$. classes), foram estudar na Ilha da Juventude, e este número se elevou para 4.800 crianças e adolescentes no ano seguinte". A atuação dos professores cubanos estava ligada, também, aos cursos de especialização técnica de nível médio para operários angolanos.

A elaboração dos primeiros programas do sistema de ensino também contou com a colaboração de profissionais cubanos, que atuavam como especialistas e assessores do Ministério da Cultura. Eles tiveram atuação significativa na área de formação de técnicos médios em saúde, além de áreas como artes, teatros, plásticas, danças e outras formas de manifestação e desenvolvimento cultural. Além dos professores formados, também iam para Angola cubanos estagiários ${ }^{42}$, que atuavam no ensino fundamental.

O plano nacional de educação, nos primeiros anos que se seguiram à independência, procurou estimular as famílias a participarem nas atividades escolares dos filhos, na luta pela redução do analfabetismo através da organização de salas de aulas, não apenas nos espaços escolares, mas também nas fábricas, nos quartéis militares, em cooperativas agrícolas e nos bairros para a alfabetização de adultos. Outro desafio que se apresentava concerne ao fato de algumas línguas nativas não possuírem escritas que possibilitassem a alfabetização. Esta situação levou o então governo a aprovar em 09 de março de 1987 a resolução (publicada no Diário da República) que regulamenta o ensino de línguas nacionais.

Segundo esta resolução, as línguas nacionais são o suporte e veículo da continuidade cultural e exigem, portanto, um tratamento privilegiado por constituírem elemento fundamental de identidade cultural angolana. Desta forma, a título experimental, foram aprovadas para a alfabetização em línguas nacionais o "Kikongo, Kibumbundo, Cokwé, Umbundu, Mbundu e Oxikwanyama e as respectivas regras de transcrição" (Diário da República de Angola, 1987 p. 212. in: Silva Neto, 2005, p. 159).

Para assegurar a inserção e organização do alfabeto das línguas nacionais criou-se em 1987 o chamado Instituto Nacional de Línguas, responsável pelos

\footnotetext{
${ }^{42}$ Estudantes universitários que iam para Angola efetuarem o seu estágio durante um período limitado, geralmente nas férias.
} 
estudos lingüísticos. Este instituto era dirigido pelos técnicos e professores angolanos e aqueles (não professores) mais velhos que tinham o conhecimento e domínio da língua. Desde 1977 o governo procurou, teoricamente, tornar obrigatório o sistema de ensino primário. Todavia, dada a situação de conflito, muitas das medidas traçadas (já mencionadas no início deste capítulo) no plano teórico, não puderam sair do papel para serem concretizadas.

\section{1 - Implementação da reforma educacional}

A necessidade de ampliar a educação se apresenta, já nos anos 50 e 60, não somente como preocupação de Angola, mas no mundo todo, como preocupação geral, impulsionada pelo avanço da tecnologia. Massificar a educação como forma de recuperação e estabilidade sóciopolítico e de desenvolvimento econômico era uma questão emergencial. Em Angola ocorre, neste período, a organização mais efetiva dos movimentos de luta pela independência nacional e a separação entre eles.

As idéias de mudanças em relação à educação respondiam assim a esta emergente preocupação de concretizar, logo depois que o país tivesse alcançado sua liberdade, a estabilidade econômica e política. Esta preocupação é expressa por um dos documentos, do início dos anos setenta, chamado Programa maior do MPLA (vide Anexo 3). Entre outras medidas traçadas, apresentamos aqui aquelas que estavam vinculados ao "desenvolvimento da instrução, da cultura e da educação". Estas visavam fundamentalmente o seguinte:

- Liquidação da cultura e da educação colonialista e imperialista. Reforma do ensino em vigor. Desenvolvimento da instrução, da cultura e da educação ao serviço da liberdade e do progresso pacífico do povo angolano.

- Combate vigoroso e rápido do analfabetismo em todo o país.

- A instrução pública será da competência do Estado e estará sob a sua acção directa.

- Tornar efectiva, progressivamente, a instrução primária obrigatória e gratuita.

- Desenvolver o ensino secundário e o ensino técnico-profissional e criar o ensino superior. 
- Estabelecimento de relações culturais com países estrangeiros. Formação e aperfeiçoamento dos quadros técnicos necessários à construção do país.

- Impulso e desenvolvimento das ciências, das técnicas, das letras e das artes.

- Instrução, no campo, de meios eficazes e suficientes para a assistência médica e sanitária das populações camponesas. Desenvolvimento equilibrado, à escala nacional, dos serviços de assistência médica e sanitária.

- Liquidação da prostituição e do alcoolismo.

- Estímulo e apoio às actividades progressistas da juventude.

- Fomento e protecção, em todo o país, da cultura física ${ }^{43}$.

Depois da independência Angola apresentava uma taxa elevada de analfabetismo, calculada nesta fase em $85 \%$ do total da população. Havia urgência em se tomar medidas para a superação desta situação que, em termos gerais, não contribuía para a solidificação de uma opção política e, muito menos, para a defesa de direitos que, a nosso ver, requer determinado conhecimento formal para que possam ser defendidos. Entendemos que o conhecimento e domínio da escrita, assim como das leis (direitos e deveres pessoais e do Estado para com a sociedade) permitem ao cidadão, não só reconhecer-se quando é bem ou injustamente governado, como também contribuir para a melhoria da vida em sociedade.

A independência ou revolução se solidifica também com um povo instruído, isto porque o agir político, econômico e até mesmo quando se trata de defender direitos, exige espaços para reflexão e acesso a informação. Percebe-se então que com um povo analfabeto as dificuldades são maiores. $\mathrm{O}$ desafio que se apresentava consistia, acima de tudo, na luta contra o analfabetismo para poder consolidar uma política que atendesse, pelo menos, às preocupações emergentes e fundamentais que o país recém independente apresentava - questões administrativas e organizacionais. Fato que não se verificou devido aos conflitos e antagonismos ideológicos que se foram propagando entre os movimentos e ao não cumprimento das obrigações propostas em acordos que visavam à formação do governo de transição. Havia também, por parte dos movimentos, uma demasiada preocupação pela apropriação do poder em substituição do poder colonial sem, no entanto, abrir espaços de debates e participação de outros movimentos na administração pública do país.

${ }^{43}$ Angola: Documentos do MPLA. Vol. 1, n. 2. Lisboa. ULMEIRO, 1977, p. 65-71. 
Com o poder nas mãos, o MPLA, de orientação política "marxistaleninista", procurou organizar uma política educativa, aprovada em 1977 e implementada em 78, como forma de responder às "necessidades do país" e à consolidação da independência nacional. Esta política, como atestam os documentos e discursos políticos da época, é caracterizada, essencialmente, pelos princípios de igualdade de oportunidades, da gratuidade no acesso à escola e da continuidade de estudos.

A substituição da política herdada do colonialismo português diante do esfacelamento a que o país estava submetido pelas lutas entre movimentos e pela instalação de um governo totalitário implicou em mudanças no currículo escolar, sobretudo na formação de professores. Estas mudanças não se deram em função de uma consolidação política (unidade nacional) entre os três partidos políticos, mas sim, da supremacia de um em detrimento de outros.

É peculiar notar-se que dada a insuficiência do quadro docente em atender a demanda, o ensino limitou-se, em muitos casos, ao ensino precário da língua portuguesa e de outras disciplinas, mas sem o conhecimento ou domínio necessário, por parte do professor, dos conteúdos de ensino. Neste período, as aulas eram ministradas, em grande parte, por monitores escolares, que mais tarde passaram à categoria de professores colaboradores e de professores propriamente ditos, mas com uma formação muito baixa (quarta classe).

A implementação de uma reforma educacional, do ponto de vista político, representava uma preocupação, pois se acreditava, como já reiteramos, que o ensino é elemento fundamental e estratégico que possibilita mudanças. Além do discurso que apontava para a necessidade de mudanças através da educação, predominou também o desejo de manter politicamente uma estrutura ideológica de domínio no país independente, o que requer distinguirmos os intentos da reforma realizada dos aspectos ideológicos subjacentes para a compreensão das dificuldades enfrentadas pela educação. Assim, pensar sobre o ensino representa não apenas uma preocupação com o saber ler e escrever, mas sim, pensar numa questão maior, que concerne ao entendimento do espaço sócio-político, econômico e cultural, das regras da convivência social, da práxis política e suas relações em sociedade. 


\section{2 - Organização do sistema educacional}

Em 1976 a organização do sistema educacional, além de representar uma questão desafiadora para o novo país, no qual se pretendia edificar uma nova cultura de paz e "liberdade", envolvia também a questão de que a educação deveria ser fundamentada nos valores culturais da sociedade angolana. Segundo Francisca do Espírito Santo (2000, p. 156), o Sistema de Educação desenvolvido caracterizava-se, basicamente, pelo aumento de oportunidades educativas, gratuidade do ensino de base (primeira à quarta classe), obrigatoriedade de freqüentar o primeiro nível e o aperfeiçoamento pedagógico do seu corpo docente.

A dificuldade que se apresentava era grande e, portanto, exigia dos seus respectivos responsáveis uma adequada capacidade de tomada de medidas objetivas que visassem permitir o rompimento com o anterior sistema. Desta forma, pensava-se terminar com o sistema de educação anterior para implementar uma educação que perspectivasse a "dignificação e unidade" do país. De acordo com o Decreto $\mathrm{n}^{\circ} .40 / 80$ de 14 de maio, o sistema educacional em vigor desde 1978 constituíase em subsistemas que compreendiam as seguintes etapas: Educação pré-escolar; Ensino Básico (de três níveis - o primeiro, da $1^{\mathrm{a}}$. à $4^{\mathrm{a}}$. classe; o segundo, da $5^{\mathrm{a}}$. à $6^{\mathrm{a}}$. classe; e o terceiro, da $7^{\mathrm{a}}$. à $8^{\mathrm{a}}$. classe); Ensino Médio (dividido em técnico e normal); Ensino Superior (bacharelado até o terceiro ano e a licenciatura até a quarto ou quinto ano, dependendo do curso); ensino e alfabetização de adultos.

Tabela 4: Estrutura de ensino implementado em 1978

\begin{tabular}{|c|c|c|c|}
\hline $\begin{array}{c}\text { Educação } \\
\text { Pré-Escolar }\end{array}$ & $\begin{array}{c}\text { Ensino de Base (Regular, } \\
\text { Adultos e Especial) }\end{array}$ & $\begin{array}{l}\text { Ensino Médio ou } \\
\text { Pré-Universitário }\end{array}$ & Ensino Superior \\
\hline Creche & $\begin{array}{c}1^{\mathrm{o}} \text {.Nível }-1^{\mathrm{a}} . \text { à } 4^{\mathrm{a}} . \text { classe } \\
\text { (Obrigatório) }\end{array}$ & $\begin{array}{l}\text { Médio Normal } \\
\left.\text { ( } 9^{\mathrm{a}} \text { à } 12^{\mathrm{a}} \text { classe }\right)\end{array}$ & $\begin{array}{c}1^{\mathrm{o}} \text {. Nível (do } 1^{\mathrm{o}} \text {. ao } 3^{\mathrm{o}} \text {. Ano) } \\
\text { (Bacharelato) }\end{array}$ \\
\hline $\begin{array}{l}\text { Jardim de } \\
\text { Infância }\end{array}$ & $\begin{array}{l}2^{0} . \text { Nível }-5^{\mathrm{a}} \text { à } 6^{\mathrm{a}} . \text { classe } \\
(\text { Formação Profissional)* }\end{array}$ & $\begin{array}{c}\text { Médio Técnico } \\
\left(9^{\mathrm{a}} . \text { à } 12^{\mathrm{a}} . \text { classe }\right)\end{array}$ & $\begin{array}{c}2^{\circ} \text {. Nível (do } 4^{\circ} \text {. ao } 5^{\circ} \text {. Ano) } \\
\text { (Licenciatura) }\end{array}$ \\
\hline Iniciação & $\begin{array}{l}3^{\circ} . \text { Nível }-7^{\mathrm{a}} . \text { à } 8^{\mathrm{a}} . \text { classe } \\
\text { (Formação Profissional)* }^{*}\end{array}$ & $\begin{array}{l}\text { Pré-Universitário } \\
\left(9^{\mathrm{a}} . \text { à } 11^{\mathrm{a}} . \text { classe }\right)\end{array}$ & \\
\hline
\end{tabular}

* Junto do ensino normal, segundo e terceiro nível, havia a formação profissional (adultos e jovens), direcionado à aprendizagem de conhecimentos com aplicação prática ao trabalho. 
Além da ordem normal em que estava estruturado o sistema de ensino havia, paralelo a este, o ensino de adultos, voltado basicamente para a alfabetização e ensino geral básico. Mediante o desenvolvimento, os adultos poderiam chegar à formação profissional técnica.

De acordo com a lei constitucional, os princípios de obrigatoriedade e gratuidade estavam restringidos à freqüência no primeiro nível de ensino de base. Segundo Francisca do E. Santo, o "processo de massificação lançado com o novo Sistema Educativo se inicia com o aumento significativo dos efectivos escolares que chegam a atingir em 1980 a 1,8 milhões de alunos, numa progressão anual de 10\%" (Espírito Santo, 2000, p. 157). Esta situação de crescimento e da procura iria obrigar o Estado a buscar uma nova estratégia política de investimento educacional para evitar que muitas crianças permanecessem fora da escola. Porém, dada a fragilidade do sistema político, o aumento do número de alunos não obteve, por parte do Estado, uma resposta adequada, resultando em conseqüências como:

- Maior concentração do número de alunos por turmas;

- Pouca capacidade, por parte da escola, para albergar os alunos e responder às suas necessidades;

- Elevado número de dificuldades no desenvolvimento do processo educacional - condições materiais, estrutura física e gestão pedagógica;

- Taxas de repetências muito altas e aumento do número de desistência antes de atingir o segundo nível (quinta e sexta classes).

- Baixo nível acadêmico de seus professores, decorrente da falta de programas de formação de professores, etc. ${ }^{44}$

Uma situação que nos parece complexa, e por isso urge ser apontada, é o caráter ideológico e demagógico presente no discurso político. Apontava-se para a igualdade e gratuidade no sistema de ensino como meta, todavia, esta meta foi sacrificada em função da prioridade dada à guerra pelo poder. Guerra que obrigava todos os jovens, sobretudo os do sexo masculino, a ingressarem nas fileiras da vida

\footnotetext{
${ }^{44}$ Neste período, a que nos referimos, quem terminava o segundo nível (quinta ou sexta classe) já poderia lecionar no primeiro nível (primeira à quarta classe).
} 
militar para um "combate não compreendido" 45 , levou à destruição das poucas infraestruturas escolares existentes e gerou a instabilidade política, social e econômica.

Como conciliar a ideologia de guerra (da defesa do poder) e a efetivação dos princípios da gratuidade e obrigatoriedade de ensino se o elevado índice de analfabetismo representava terreno propício para aqueles que pretendiam dominar com maior facilidade possível e com isso garantirem sua permanência no poder? Que educação foi pensada, de modo geral, para o país durante estes anos de guerra? Quais resultados a educação apresenta hoje? É importante que estas questões sejam levantadas para se pensar profundamente sobre o problema de ensino de Angola. Não queremos com isso ignorar a "vontade" de melhoria manifestada por parte do Estado, em seu discurso político, durante o período de guerra.

Para a materialização dos princípios de liberdade e gratuidade em instituições escolares o país teria, necessariamente, que estar em paz e as pessoas em liberdade, em termos de pensamento político e, sob esta base, efetivar-se uma educação capaz de levar ao entendimento de questões políticas fundamentais à sociedade angolana. Ao contrário disso, a preocupação de defesa do poder pelo poder, sem investimento adequado no setor educacional e sem distribuição de renda para o ensino, que tivesse em conta as diferenças regionais e culturais do país, parece-nos que falar de igualdade e gratuidade não passou de uma proposta demagógica. Ou se enganaram sobre o seu valor ou se iludiram face à precariedade das soluções tomadas para a educação do país pós-colonial.

As conseqüências advindas da superficialidade das soluções não tardaram em se fazer presente. Para responder a esta situação realizou-se em 1986 o primeiro diagnóstico do sistema educacional, e a partir daí foram apontadas novas linhas para a projeção de um novo sistema educativo, que resultou na elaboração do documento denominado "Estudo Sectorial de Educação" (Espírito Santo, 2000, p. 157).

A organização e gestão do sistema de ensino apresentava-se de uma forma centralizada. Suas estruturas estavam organizadas sob dependência vertical, situação essa que limitava as iniciativas, por parte das províncias - das administrações locais - para poderem desenvolver um sistema educacional adequado a cada província

\footnotetext{
${ }^{45}$ Grande parte dos jovens capturados e obrigados a ingressar nas fileiras da vida militar, tanto na UNITA como no MPLA e na FNLA, não tinha grande entendimento, isto é, não sabiam quais razões concretas os levaria a combater contra outro angolano, uma vez que a independência tinha sido alcançada. A maior parte destes jovens capturados era analfabeto.
} 
ou região, dependendo da língua. Tal como o sistema político do governo e de seus órgãos institucionais, a estrutura organizacional da educação previa, segundo Francisca do E. Santo (2000), alguns órgãos

\footnotetext{
encarregados das responsabilidades administrativas e de gestão. Desde o nível central estes órgãos dispõem de vários Directores Nacionais e Chefes de departamentos sob a autoridade do Ministro ou do Vice-ministro, incluindo os Delegados Provinciais, os quais têm sob sua responsabilidade as delegações municipais e estas, as Coordenações Comunais e Direções de Escolas (Espírito Santo, 2000, p. 159).
}

As províncias apresentavam diferenças lingüísticas (Umbundo, Kimbundo, Kikongo, Chokwe, Nganguela, Nhaneka, etc.) que necessitavam ser consideradas na nova estrutura educacional para com isso, atender às manifestações culturais que como se sabe, variam de região para região e de uma língua para outra. Existem elementos comuns, mas são em muitos aspectos diferentes e apresentam estruturas e manifestações culturais centrais diferenciadas. Em suma, entendemos que é importante ter-se em conta essas diferenças na formulação do sistema educacional, como também, na organização do material didático para a alfabetização de crianças, adolescentes e, sobretudo, de adultos que não conseguem comunicar-se em língua portuguesa.

\section{3 - Abrangência do sistema educacional}

\subsection{Educação pré-escolar e iniciação}

A educação pré-escolar, conforme foi dito no ponto anterior, estava subdividida em creche (de 1 a 3 anos de idade) e jardim de infância (de 4 a 5 anos de idade). A iniciação era feita, normalmente, aos cinco ou seis anos de idade e, depois desta fase, a criança começava a primeira classe do ensino básico normal. 
A educação pré-escolar para crianças, apesar de constar no organigrama $^{46}$, (Tabela 4) não foi vista como uma preocupação vital do Estado, mas sim da sociedade e mais concretamente das famílias. O que mais se proliferou até início dos anos noventa foi a iniciação, mas, devido à falta de vagas ou escolas perto, muitas crianças acabavam fazendo a iniciação aos seis ou sete anos. Por outro lado, a situação de conflitos que se propagou pelo país inviabilizava quaisquer iniciativas de organização de programas públicos de atendimento à crianças em idade para a préescola. Primeiro, porque as atenções estavam voltadas ao investimento no material militar, isto é, à potencialização das forças de defesa, segundo, porque o deslocamento constante das famílias, em função desta guerra, impedia-as de reunir condições necessários para as crianças freqüentarem a pré-escola.

A pouca atenção dada aos problemas sociais, durante os anos finais da década de setenta até início de dois mil não se restringe apenas ao ensino. Alastra-se também para as áreas da saúde, onde os índices de mortalidade infantil são preocupantes. As crianças (menores de 14 anos), além de representarem, aproximadamente $43 \%$ da população foram atingidas particularmente, também, pela situação de guerra. Como mostram os dados de 1995, apresentados por Francisca do E. Santo (2000, p. 159). “1,5 milhões de crianças estão afectadas física, psicológica e emocionalmente; destas, 840000 se encontram em condições particularmente difíceis. 500000 crianças foram vítimas mortais da guerra”. Esta situação dificultou, não só, a boa aprendizagem e desenvolvimento da criança, nesta fase inicial e decisiva para as outras fases posteriores, como também no desenvolvimento físico e psicológico.

Estes dados permitem-nos perceber que, durante a guerra, as leis de defesa ao menor, e as leis internacionais de defesa à infância não foram observadas, mesmo que em algum momento se tenha aderido à carta internacional dos direitos humanos e dos cuidados à infância. Além disso, nota-se também uma fraca expressividade de movimentos populares que poderiam manifestar-se contra. E quando se tentava fazer havia repressão do Estado em relação a estes movimentos reivindicadores. A repressão acontecia, não só, como forma de impedir a organização forte de movimentos e sua manifestação como também aos meios de comunicação que, até então, suas informações passavam pela vistoria do Estado.

\footnotetext{
${ }^{46}$ Organograma, Brasil.
} 
Além dos dados apontados por Francisca do E. Santo é importante saber que não se tem, no momento, um dado exato de quantas crianças encontram-se em situações desumanas, mesmo agora depois da guerra, pois a inacessibilidade em várias regiões, devido a falta de estradas e pontes destruídas, impedem um cálculo mais preciso do número de crianças que se encontram sem atendimento escolar, hospitalar e alimentar (cuidados primários). E, de acordo com um estudo sobre a situação da vida das crianças, realizado em Angola, (Documentos, 1998) apoiado pela UNICEF, do qual participaram ONGs, ONU e outros membros de Angola ligados à saúde e educação e outras áreas, sente-se uma grande ausência de estratégias que pudessem possibilitar a criação de uma política pública de valorização da infância, que resultasse em melhorias dos cuidados primários.

Segundo os dados do Ministério da Saúde apresentados no relatório para o desenvolvimento do milênio em 2003, mais de 75 mil mortes são registradas durante o ano entre crianças cuja faixa etária varia de zero aos cinco anos de idade. De acordo com os dados do INE (Instituto Nacional de Estatísticas) e da UNICEF, em 1998, o número de crianças que morriam em cada 1.000 crianças nascidas era de 274 , acima de Moçambique (214) e Zâmbia (202) e um pouco melhor se comparado com o Niger, que no mesmo ano de 1998 apresentava 320 casos de mortes para cada 1.000 crianças nascidas (In: Documentos, 1998, p. 36). Já os dados de 2002 a 2005 apresentam uma pequena melhoria se comparados aos dados de 1998, registrando 190,5 mortes em cada 1.000 crianças nascidas. Esses dados ainda são muito elevados se comparados com países "mais ou menos desenvolvidos", onde os índices de mortalidade infantil são de menos de 30 para cada 1.000 crianças nascidas. Em Angola têm sido apontado casos de diarréia aguda, infecções respiratórias agudas, além dos casos de sarampo e malária, como os principais causadores do elevado índice de mortalidade infantil. Contudo, não se questionava o papel ou contribuição do Estado na tomada de medidas para pôr fim a esta situação, não se questionava a posição política, econômica e sócio-educativa deste, diante da problemática situação que resultou da guerra em defesa do poder, até 2002.

O Ministério da Saúde aponta a má nutrição, a fraca resposta à questão de saúde materno-infantil, além do saneamento básico (tratamento e distribuição da água potável), que é, também, responsabilidade do Estado, como fatores que têm contribuído para as elevadas taxas de mortalidade infantil. Ora, importa 
questionar as políticas de saúde do Estado, o atendimento aos profissionais de saúde (qualificação profissional, condições econômicas e estrutura física dos hospitais), as políticas públicas e programas integrados saúde/educação que poderiam estar voltados ao atendimento das crianças dos 0 aos 5 anos de idade. Segundo o Relatório, que trata dos objetivos de desenvolvimento do milênio (2003),

é difícil saber se Angola está seguindo ou não a evolução necessária para atingir a meta de reduzir em dois terços a taxa de mortalidade dos menores de 5 anos para o ano 2015; durante a guerra muitas áreas de difícil acesso ficaram sem controle do Governo. Com o fim da guerra e a subseqüente abertura de novas áreas acessíveis, a maior notificação de casos provavelmente produzirá uma outra visão (Relatório MDG/NEPAD, 2003, p. 48).

Tem havido iniciativas, por parte de instituições como a UNICEF, UNESCO, ONGs e do Instituto Nacional da Criança, com o objetivo de contribuir para melhoria e superação da situação apresentada pelo país. Porém, os financiamentos têm sido insuficientes diante de uma situação que aumenta a cada dia, à medida que nas áreas onde não se tinha acesso aparecem também casos novos de mortalidade infantil. A estrutura social e educativa de centros infantis e creches existentes apresentava, no ano de 2000, um acesso limitado, atendendo 1\% apenas das crianças em idade pré-escolar (Espírito Santo, 2000, p. 160). Isso não difere muito dos dados de 2005 (1,2\%) devido ao crescimento da população e à volta de todos aqueles que, durante a guerra, tinham-se refugiado em países vizinhos, mais concretamente nas fronteiras da Zâmbia, Namíbia e da República Democrática do Congo (antigo Zaire).

Como exemplo, pode-se verificar que, nos dados de freqüência dos alunos na pré-escola (iniciação) de 1990 a 1998 (Tabela 5), apresentados por Conjimbi, na semana da educação, ocorrida em Luanda no ano de 1999, houve uma diminuição significativa devido aos conflitos militares. $\mathrm{O}$ número de crianças que freqüentavam a escola no período de 1992 a 1993 sofreu uma redução quando comparado com o intervalo de anos compreendido entre 1994 e 1998. A intensificação dos ataques militares no país (entre a UNITA e o MPLA) teve uma repercussão grande na diminuição do fluxo de crianças nas escolas. $\mathrm{O}$ elevado número de inscrições registrado de 1990 a 1992 deve-se a um período de paz, em que se realizaram os acordos de cessar 
fogo com vistas a preparar as primeiras eleições, que viriam acontecer em setembro de 1992.

Tabela 5: Frequiência dos alunos na iniciação (1990-1998)

\begin{tabular}{lccccccc}
\hline Nível / Ano & $1990 / 1$ & $1991 / 2$ & $1992 / 3$ & $1993 / 4$ & $1994 / 5$ & $1995 / 6$ & $1997 / 8$ \\
Iniciação & 164.141 & 188.710 & 109.917 & 168.675 & 100.778 & 109.265 & 157.493 \\
\hline
\end{tabular}

Fonte: Conjimbi, 2000, p. 173.

Desde o ano de 1992/3 a 1995/7 verificou-se uma diminuição significativa de crianças no acesso à formação inicial, que constitui uma base preparatória para poder ingressar nas classes seguintes (primeiro nível). É importante salientar-se também que o atendimento a crianças na pré-escola, além de não representar para o Estado uma preocupação fundamental, carece de material pedagógico para o desenvolvimento lúdico, visual, motor, etc. e de especialistas - professores qualificados - em educação pré-escolar.

\subsection{Ensino básico ( $\left(1^{\mathrm{a}}\right.$. a $8^{\mathrm{a}}$. classe $)$}

Subdivide-se em ensino regular, educação de adultos e ensino especial. O ensino básico engloba o primeiro nível obrigatório $\left(1^{\mathrm{a}}\right.$. a $4^{\mathrm{a}}$. classe $)$, dos 6 aos 9 anos de idades, o segundo nível ( $5^{\mathrm{a}}$. e $6^{\mathrm{a}}$. classes), dos 10 aos 11 anos, e o terceiro nível ( $7^{\mathrm{a}}$. e $8^{\mathrm{a}}$. classes), dos 12 aos 13 anos de idade. Paralelo ao ensino de base, havia também a formação profissional, dividida em dois ciclos: o primeiro ciclo da $5^{\mathrm{a}}$. à $6^{\mathrm{a}}$. classe e o segundo ciclo da $7^{\mathrm{a}}$. à $8^{\mathrm{a}}$. classe. Esta formação estava destinada, sobretudo, àqueles que pretendiam trabalhar como professores nas escolas de alfabetização, primeiras e segundas classes do primeiro nível.

O principal objetivo que o ensino básico procurava atingir, segundo o Ministério da Educação (2004, p. 19. vol. 5), era a "formação integral do cidadão, através de uma série de conhecimentos gerais, preparando o jovem para a continuação de sua formação a nível médio e superior ou permitindo a aquisição de habilidades e saberes" necessários à convivência social e à sua inserção na vida ativa da sociedade. 
Encontra-se ligada a este ensino básico uma classe preparatória (iniciação) que visa, em termos gerais, adaptar a criança ao ambiente escolar, prepará-la para maior interação com seus semelhantes e um melhor desempenho na primeira classe. Diferente de outras classes, na iniciação não é obrigatório que as crianças passem por uma avaliação que vise reprovar aqueles que possivelmente não venham a adaptar-se devidamente ao ambiente escolar. Faz-se apenas o acompanhamento da criança para que ela consiga reunir os requisitos a que esta classe se propõe - uma fase de preparação para a primeira classe.

O desenvolvimento do ensino básico não segue o mesmo ritmo de crescimento, em todas as províncias, dadas as diferenças administrativas, e o nível de estabilidade política, social e econômica. Das dezoito províncias que Angola possui pode-se constatar, fazendo uma divisão deste conjunto de províncias por três, (Tabela 7) aquelas que apresentam maior índice de alfabetização e aquelas que apresentam menos. Do total de crianças em idade escolar (ensino básico), que, em 1995, calculava-se em 3.218.860, o que correspondia a apenas 26,3\% da população de Angola, verifica-se que menos da metade destas estavam freqüentando o ensino básico.

De forma geral, segundo o Ministério da Educação, os dados de 1990 a 1998 mostram uma pequena melhoria na educação básica, passando de 45,5\% para $55 \%$ o número de alunos que frequientam as escolas em todo o país. Os dados de 2005 apontam para $63,4 \%$. E mesmo assim se faz sentir o constrangimento que resulta do analfabetismo, afetando significativamente o desenvolvimento nacional do país, pois o número de crianças que se encontram fora da escola é ainda bastante significativo.

\footnotetext{
Os factores que podem explicar esta situação são o insuficiente número de professores, o fraco investimento no ensino de base, a limitada prioridade dada a este nível escolar, reflectida na distribuição das despesas do sector [...], a baixa qualidade reflectida nos elevados níveis de repetência, e as conseqüências da retracção da rede escolar por causa da guerra (Relatório de Progresso MDG/NEPAD: Angola, 2003, p. 36).
}

Como se sabe o desenvolvimento da educação não é isolado das restantes atividades produtivas do país. Sendo assim, parece-nos que é vital que se estabeleça um equilíbrio entre o nível de vida econômica do país e a educação. 
Educação sem investimento adequado $^{47}$ não permite avanço tecnológico, pesquisas inovadoras. E uma reforma da ordem do conteúdo e dos níveis, sem reestruturar o sistema administrativo de ensino e o investimento, não é suficiente para obter-se um crescimento e desenvolvimento cultural favorável.

Segundo o Ministério da Educação os dados - taxa bruta e líquida de escolarização primária e taxa de sobrevivência escolar - que a educação apresenta não são suficientes para atingir-se as perspectivas que o Estado pretende até o ano de 2015. Para concretizar estas perspectivas pretende-se aumentar a infra-estrutura, o número de vagas e matricular todas as crianças que estão fora do sistema escolar. O crescimento da taxa de ensino primário atingiu 9,5\% de 1990 a 1998. Ainda de acordo com o Ministério da Educação, o investimento que está sendo feito no setor educacional $(3,82 \%, 2006)$ e na área de saúde $(4,42 \%, 2006)^{48}$ ainda não tem sido suficiente diante das necessidades sociais criadas pela guerra civil. O projeto de construção de escolas não está sendo concretizado, sobretudo nas regiões mais afastadas das cidades. Continua havendo dificuldade de acesso ao material escolar ou pedagógico (elevado custo) e formação insuficiente de professores.

A Tabela 6, a seguir, mostra-nos a taxa de escolarização primária de 1990 e 1998, e nela pode-se notar que o número de permanência das crianças matriculadas no início do ano letivo é inferior ao número de crianças que conseguiam chegar à $5^{\mathrm{a}}$. classe. Entre os fatores que influenciam o baixo número de alunos que permanece matriculado destacam-se as deslocações das famílias e a questão do número de vagas, que é inferior (nas classes mais avançadas) ao do primeiro nível ( $1^{\mathrm{a}}$. à $4^{\mathrm{a}}$. classe). Isso leva muitos alunos, mesmo passando de ano, a ficarem na lista de espera até que surja uma vaga, que se dá pela desistência de outros.

Contudo, comparando os dados de 1990 (19,8\%) com os de 1998 $(27,9 \%)$ percebe-se que o número de alunos que permanecem, em cada 100 alunos inscritos na primeira classe, aumentou. Contribuiu para esta elevação o surgimento de escolas particulares que, até 1990, não existiam no país devido ao sistema político, que até então não permitia a existência de instituições de ensino particular.

\footnotetext{
${ }^{47}$ Gerência dos recursos disponíveis para a educação, distribuição eqüitativa de suas infra-estruturas, etc. 48 Diário da república de Angola. Orçamento Geral do Estado, 2005. Maiores detalhes a respeito do investimento em educação, nos anos de 2003 a 2006, estão no segundo capítulo, nas tabelas 18, 19 e 20.
} 
Tabela 6: Taxa de escolarização primária e de sobrevivência escolar

\begin{tabular}{lrrr}
\hline & $\mathbf{1 9 9 0}$ & $\mathbf{1 9 9 8} \mathbf{2 0 1 5}^{\star}$ \\
Taxa líquida de escolarização primária & 45,5 & 55 & 100 \\
\% dos alunos inscritos na 1. classe que atingem a 5.classe & 19,8 & 27,9 & 100 \\
\hline
\end{tabular}

Fonte: Ministério da Educação. In: Relatório de Progresso MDG/NEPAD. Angola, 2003, p. 36.

* Meta que se pretende atingir até o ano de 2015.

Ainda segundo o Relatório de 2003, que trata dos objetivos do desenvolvimento do milênio em Angola, a situação que pode explicar a causa do baixo índice de desenvolvimento humano que tem sido notado, e com drásticas conseqüências no desenvolvimento potencial, é o nível educacional. Estima-se que "26\% da população com mais de 15 anos sejam analfabetas, havendo outras estimativas que apontam para $50 \%$, e que a taxa de escolarização do ensino básico se situa nos 57\%" (Relatório MDG/NEPAD, 2003, p. 10). Quase um terço das crianças encontra-se na situação de nunca freqüentar ou nunca freqüentaram a escola. $\mathrm{O}$ calculo do índice de analfabetismo em Angola, até o ano de 2003, limitou-se às províncias de Luanda, Benguela, Cabinda e outras cidades acessíveis no período de guerra. Os dados têm sido apresentados mais em aproximações (dados aproximados), o que faz com que haja disparidade, por exemplo, entre os dados do INE (Instituto Nacional de Estatística) e os da PNUD, UNICEF e outros órgãos não-governamentais que atuam em Angola.

Enquanto os dados do Ministério da Educação apontavam para uma taxa de alfabetização de $55 \%$ no país em 1998, por outro lado, segundo as estimativas do Banco Mundial e da UNICEF, a taxa de analfabetismo estava calculada em $60 \%$ neste ano de 1997 a 1998. Portanto mais da metade da população encontrava-se na condição de analfabetismo. Espera-se, com o fim da guerra, que se obtenham, através de novas pesquisas, dados mais exatos que permitam ter uma visão mais abrangente da questão do analfabetismo em Angola, assim como da freqüência e desistência de alunos matriculados anualmente.

Outro fator que os resultados do IRDF (Inquérito às Receitas e Despesas Familiares) realizado pelo INE (Instituto Nacional de Estatística) mostra-nos é o da pobreza que o país apresentava em 2000. O resultado deste ano indicava que a pobreza abrangia "cerca de $68 \%$ da população, havendo $26 \%$ em situação de pobreza extrema". Cabe ainda lembrar que em Angola a "fronteira para a pobreza extrema está situada em 22,8 USD por mês (0.76 USD por dia) e em 51,2 USD (1.70) para a pobreza. 
A nível internacional considera-se o limiar da pobreza em 2 USD/dia e o da pobreza extrema em 1 USD/dia" (Relatório MDG/NEPAD, 2003, p. 9).

A demanda escolar, cada vez mais alta, fazia com que o número de alunos por sala ultrapassasse os quarenta. Isso afetou, por um lado, o nível de aproveitamento dos alunos e, por outro, a preparação do seu quadro docente, que não atendia o desafio posto pela demanda escolar o que de alguma forma contribui para que a cada "100 alunos matriculados na $1^{\mathrm{a}}$. classe apenas 30 concluem a $4^{\mathrm{a}}$. classe e 15 a $6^{\mathrm{a}}$. classe. Na $1^{\mathrm{a}}$. classe a taxa de reprovação ultrapassa os 30\%" (Relatório MDG/NEPAD, 2003, p. 11). Entre outras causas do fracasso escolar, o Relatório de 2003 apresenta as seguintes: deslocação forçada das famílias em conseqüência da guerra, deficiente grau de cobertura da rede escolar, trabalho infantil e fatores de natureza cultural e uma elevada taxa de desperdício de recursos.

As possibilidades de acesso ao ensino não seguem o mesmo ritmo por questões administrativas e disparidades no repasse de recursos destinados ao ensino das províncias, o que faz com que algumas tenham maior ou menor número de crianças fora do sistema escolar. O quadro (Tabela 7) abaixo mostra as províncias que abrangem maior ou menor número de crianças.

Tabela 7: Abrangência do ensino básico nas províncias

\begin{tabular}{lll}
\hline \multicolumn{1}{c}{ Inferior a $\mathbf{4 0 \%}$} & \multicolumn{1}{c}{ Entre $\mathbf{4 0}$ e $\mathbf{6 0 \%}$} & \multicolumn{1}{c}{ Superior a $\mathbf{6 0 \%}$} \\
\hline Bié & Cunene & Bengo \\
Huambo & Kwanza-Norte & Benguela \\
Kwando Kubango & Kwanza-Sul & Cabinda \\
Malange & Luanda-Norte & Huíla \\
Moxico & Lunda-Sul & Luanda \\
Uíge & Zaire & Namibe \\
\hline
\end{tabular}

Fonte: Espírito Santo 2000, p. 161.

A partir desta tabela percebem-se as diferenças existentes em termos de atendimento da educação e seu nível de abrangência. Percebe-se também que a obrigatoriedade apontada pelo Estado - para as primeiras quatro séries iniciais - ainda não está devidamente implementada, pois as infra-estruturas existentes não comportam todas as crianças em idade escolar. Destacam-se também as dificuldades que provêm da falta de material didático, que se juntam às "precárias condições de vida dos docentes e dos encarregados de educação" (Espírito Santo, 2000, p. 161). 
A não permanência na escola, devido à precariedade das condições, faz com que, à medida que se aumenta de nível, seja maior o número de alunos que se encontram fora do sistema escolar. Esta situação não provém simplesmente da falta de interesse (dos alunos), mas sim da falta de uma estrutura (espaço escolar) suficiente, que possa receber os alunos que terminam, por exemplo, o primeiro nível para continuar com o segundo, terceiro nível e o ensino médio. Como Espírito Santo (2000, p. 163) destaca em seu texto, o "cumprimento da escolaridade obrigatória constitui objetivamente um dos indicadores que permitem aferir da acessibilidade de um sistema educativo, enquanto a verificação do seu não cumprimento constitui factor objectivo de inequidade".

De acordo com a Tabela 8, de 1990 a 1998, notou-se uma relativa estabilidade nos primeiros dois anos letivos (1992/3) e um decréscimo, com a retomada da guerra, em 1993, que se deu depois das primeiras eleições presidências (setembro de 1992). O número de alunos reduziu-se bastante, as vezes por motivos de deslocamento, de uma província para outra, ou das infra-estruturas destruídas, além da situação de reprovação. A tabela também nos permite perceber, entre outras situações, a diminuição constante de alunos à medida que se aumenta de nível escolar. Enquanto que, no ano letivo de 1990/1, no primeiro nível, se tinham 990.155 alunos inscritos ( $1^{\mathrm{a}}$. à $4^{\mathrm{a}}$. classe), no terceiro nível apenas estavam inscritos $34.626\left(7^{\mathrm{a}}\right.$. à $8^{\mathrm{a}}$. classe $)$. O mesmo se repetia nos anos seguintes, ou seja, menos da metade dos alunos inscritos no primeiro nível conseguiam concluir o terceiro nível.

Tabela 8: Tendência de evolução de 1990 a 1998

\begin{tabular}{rrrrrrrrr}
\hline Nível/Ano & $1990 / \mathbf{1}$ & \multicolumn{1}{c}{$\mathbf{1 9 9 1 / 2}$} & \multicolumn{1}{c}{$\mathbf{1 9 9 2 / 3}$} & \multicolumn{1}{c}{$\mathbf{1 9 9 3 / 4}$} & $\mathbf{1 9 9 4 / 5}$ & $\mathbf{1 9 9 5 / 6}$ & $\mathbf{1 9 9 6 / 7} *$ & $\mathbf{1 9 9 7 / 8}$ \\
I Nível & 990.155 & 989.443 & 697.486 & 907.480 & 966.622 & 835.760 & $?$ & 853.658 \\
II Nível & 124.873 & 147.047 & 107.412 & 132.496 & 131.278 & 129.879 & $?$ & 132.336 \\
III Nível & 34.626 & 42.290 & 41.339 & 50.077 & 61.025 & 63.002 & $?$ & 69.797 \\
Total & 1.149 .654 & 1.178 .780 & 846.237 & 1.090 .053 & 1.158 .925 & 1.028 .641 & $?$ & 1.055 .791 \\
\hline
\end{tabular}

Fonte: Conjimbi, 2000, p. 173.

* No ano de 1996/7, devido às greves que se vinham registrando no país, o calendário escolar, que até então se dava de setembro a junho, passou por uma reorganização. Assim sendo, a partir de 1997, as aulas passaram não mais a começarem em setembro, mas sim em fevereiro.

A não permanência e continuidade de alunos no ensino de $1^{\mathrm{a}}$. à $8^{\mathrm{a}}$. classe se repete quase todos os anos. Como se pode notar, por exemplo, no ano letivo de 
1997 a 1998, o número geral de freqüência mostra também que há uma desproporção na repartição, pois, enquanto que, nas séries iniciais, temos uma maior concentração de alunos, no terceiro nível o número de alunos é muito inferior se comparado ao dos alunos ingressantes no primeiro nível (de $1^{\mathrm{a}}$. à $4^{\mathrm{a}}$. classe).

A Tabela 9 mostra a decaída que acontece à medida que se passa de um nível para outro. O maior número está concentrado no primeiro nível.

Tabela 9: Freqüência geral de alunos (1997-1998)

\begin{tabular}{cccc}
\hline Nível & Classe & Freqüiência & \% \\
& Iniciação & 157.493 & 12,9 \\
I Nível & $1^{\mathrm{a}}$ a $4^{\mathrm{a}}$ Classe & 853.658 & 70,4 \\
II nível & $5^{\mathrm{a}}$ a $6^{\mathrm{a}}$ Classe & 132.336 & 10,9 \\
III Nível & $7^{\mathrm{a}}$ a $8^{\mathrm{a}}$ Classe & 69.797 & 5,8 \\
Total & & $\mathbf{1 . 2 1 3 . 2 8 4}$ & $\mathbf{1 0 0}$ \\
\hline
\end{tabular}

As taxas de escolarização registradas no ano letivo de 1997/8 também mostram quantas crianças em idade escolar, dos 6 aos 14 anos, estavam escritas nas escolas, porém nem todas freqüentavam a escola por falta de vagas. As crianças inscritas chegavam a 2.874.100, o que representa $58,7 \%$ deste grupo etário. Por outro lado, as crianças em idade escolar fora do sistema de ensino, na mesma idade, eram 2.020.442, isto é, 41,3\% deste grupo etário. Um dado importante é notar que, fazendo uma comparação entre os sexos, o número maior de alunos fora do sistema escolar é feminino, com 1.035.876, enquanto que o masculino é de 984.566.

Fazendo uma comparação dos alunos do segundo nível $\left(5^{\mathrm{a}}\right.$. e $6^{\mathrm{a}}$. classes) por sexo e por província notam-se, também, a predominância do masculino e a pouca participação feminina. Esta situação acontece sobretudo por falta de incentivo no coletivo social e de espaço dedicado à valorização da participação da mulher dentro da sociedade angolana.

A Tabela 10 ilustra-nos, em números, como se deu a participação feminina e masculina no segundo nível (da $5^{\mathrm{a}}$. à $6^{\mathrm{a}}$. classe) no ano letivo de 1997/8. 
Tabela 10: Alunos matriculados no II $^{0}$. Nível em 1997/8

\begin{tabular}{lrrrrrrrr}
\hline & \multicolumn{2}{c}{$\mathbf{5}^{\text {a. }}$ classe } & \multicolumn{2}{c|}{$\mathbf{6}^{\text {a classe }}$} & \multicolumn{2}{c|}{ Soma } & \% \\
\hline \multicolumn{1}{c}{ Província } & $\mathbf{M}+\mathbf{F}$ & \multicolumn{1}{c}{$\mathbf{F}$} & $\mathbf{M}+\mathbf{F}$ & \multicolumn{1}{c}{$\mathbf{F}$} & $\mathbf{M}+\mathbf{F}$ & $\mathbf{F}$ & $\mathbf{F} / \mathbf{M + F}$ \\
Cabinda & 3.187 & 1345 & 1667 & 689 & 4854 & 2034 & 42,1 \\
Zaire & 948 & 227 & 357 & 112 & 1.305 & 339 & 26,1 \\
Uíge & 1.851 & 577 & 1.509 & 397 & 3.360 & 974 & 29 \\
Luanda & 37.974 & 19.725 & 28.869 & 15.133 & 66.843 & 34.858 & 52,1 \\
Kwanza-Norte & 1.132 & 270 & 411 & 94 & 1.543 & 364 & 23,5 \\
Kwanza-Sul & 3.967 & 1.574 & 1.967 & 641 & 5.934 & 2.215 & 37,3 \\
Malange & 2.277 & 1.002 & 1.110 & 551 & 3.387 & 1.553 & 45,8 \\
Lunda-Norte & 1.082 & 317 & 659 & 149 & 1.741 & 466 & 26,8 \\
Lunda-Sul & 245 & 97 & 232 & 68 & 477 & 165 & 34,6 \\
Benguela & 10.755 & 4.822 & 5.436 & 2.727 & 16.191 & 7.549 & 46,6 \\
Huambo & 5.358 & 2.329 & 3.346 & 1.358 & 8.704 & 3.687 & 42,3 \\
Bié & 1.730 & 575 & 872 & 290 & 2.602 & 865 & 33,2 \\
Moxico & 569 & 190 & 372 & 169 & 941 & 359 & 38,2 \\
Kuando-Kubango & 353 & 75 & 195 & 66 & 548 & 141 & 25,7 \\
Namíbia & 1.451 & 798 & 1.189 & 557 & 2.640 & 1.355 & 51,3 \\
Huíla & 6.738 & 3.047 & 2.501 & 616 & 9.239 & 3.663 & 39,6 \\
Cunene & 898 & 554 & 382 & 226 & 1.280 & 780 & 60,9 \\
Bengo & 503 & 203 & 252 & 102 & 755 & 305 & 40,4 \\
\hline Total & $\mathbf{8 1 0 1 8}$ & $\mathbf{3 7 7 2 7}$ & $\mathbf{5 1 3 2 6}$ & $\mathbf{2 3 9 4 5}$ & $\mathbf{1 3 2 . 3 4 4}$ & $\mathbf{6 1 6 7 2}$ & $\mathbf{4 6 , 6}$ \\
\hline
\end{tabular}

Fonte: Ministério da Educação. In: Conjimbi, 2000, p. 178.

Analisando a taxa bruta ${ }^{49}$ de escolarização que cada província apresentou no ano de letivo de 1997/8, constataram-se os seguintes dados:

Tabela 11: Taxa bruta de escolarização por províncias ${ }^{50}(1997 / 8)$

\begin{tabular}{|l|c|}
\hline \multicolumn{1}{|c|}{ Província } & \multicolumn{1}{c|}{$\begin{array}{c}\text { Taxa bruta de } \\
\text { escolarização }\end{array}$} \\
\hline Cabinda & $158,3 \% *$ \\
\hline Zaire & $37 \%$ \\
\hline Uíge & $19,1 \%$ \\
\hline Luanda & $95,3 \%$ \\
\hline Kwanza Norte & $42,9 \%$ \\
\hline Kwanza Sul & $86,5 \%$ \\
\hline Malange & $20,1 \%$ \\
\hline Lunda Norte & $39 \%$ \\
\hline Lunda Sul & $37,5 \%$ \\
\hline Benguela & $115,2 \% *$ \\
\hline Huambo & $16,9 \%$ \\
\hline Bié & $26,7 \%$ \\
\hline
\end{tabular}

${ }^{49}$ A taxa bruta indica o número total de crianças inscritas no ensino. isso não significa que todos tenham freqüentado as aulas durante o ano letivo e que ao final do ano transitaram para a classe seguinte.

50 * As províncias de Cabinda e Benguela apresentaram dados acima de $100 \%$ por incorporarem nas inscrições crianças ou adolescentes fora da faixa etária normal deste nível escolar. 


\begin{tabular}{|l|c|}
\hline Moxico & $18,9 \%$ \\
\hline Kuando-Kubango & $46,2 \%$ \\
\hline Namíbia & $93,3 \%$ \\
\hline Huíla & $90,7 \%$ \\
\hline Cunene & $69,8 \%$ \\
\hline Bengo & $39 \%$ \\
\hline
\end{tabular}

Fonte: Conjimbi, 2000, p. 175.

Como dizia Conjimbi (2000, p. 175), durante a semana da educação ocorrida em Luanda em 1999, as províncias que normalmente têm apresentado "taxas superiores a 100\%" demonstram que "o ensino do $\mathrm{I}^{\mathrm{O}}$ Nível atende um número significativo de crianças que se encontram fora da faixa etária oficial”, enquanto que as "taxas inferiores a 100\% indicam insuficiência da oferta nessas províncias".

A tabela acima mostra-nos também que, por um lado, as dezoito províncias de Angola não têm o mesmo nível de cobertura educacional, isto é, os alunos não recebem a mesma atenção, por parte do governo e, por outro lado, nota-se também que os governos locais (governo provincial) carecem de políticas eficientes para incentivar a formação do seu quadro docente e a melhoria da estrutura de ensino. Isso proporcionaria a permanência da criança na escola e conseqüentemente a continuidade para níveis posteriores.

\subsection{Ensino médio normal e técnico}

Este nível de ensino estava organizado ou subdividido em préuniversitário, com três anos de duração $\left(9^{\mathrm{a}}\right.$. à $11^{\mathrm{a}}$. classe), ensino médio normal, com quatro anos de duração $\left(9^{\mathrm{a}}\right.$. à $12^{\mathrm{a}}$. classe $)$ e ensino médio técnico, também com quatro anos de duração $\left(9^{\mathrm{a}}\right.$. à $12^{\mathrm{a}}$. classe $)$.

De forma geral o ensino médio normal ou técnico atende jovens e adolescentes com idade compreendida entre catorze e dezoitos anos. Havia também o ensino médio chamado de pré-universitário (PUNIV). No sistema anterior à independência de Angola, este era tido como uma etapa de transição entre a fase final do ensino secundário do sistema colonial para o acesso ao ensino superior. $\mathrm{Na}$ nova organização (1976) este nível foi estruturado em quatro semestres letivos (dois anos). 
Mas a partir de 1986 foi feita ainda uma nova reestruturação deste nível de ensino, passando de quatro para seis semestres (três anos).

Existiam duas modalidades de ensino médio. O técnico e o normal. A formação técnica em nível médio, realizada nos institutos médios técnicos, visava propiciar uma formação técnica qualificada àqueles que pretendiam incorporar-se ao mercado de trabalho, dependendo da área de formação. As áreas que mais atendiam a esta perspectiva de formação eram as do setor industrial, agricultura, pescas, administração, saúde, petróleo, serviço social, telecomunicações e economia. Desta forma esperava-se responder às perspectivas do mercado de trabalho mediante a formação profissional.

O ensino médio normal, realizado no Instituto Médio Normal (IMN), tinha por objetivo a formação daqueles que desejavam trabalhar como professores do ensino de base ( $1^{\mathrm{a}}$. à $6^{\mathrm{a}}$. classe). Mas devido à falta de professores formados, em várias províncias ou municípios, estes professores de nível médio acabavam por lecionarem também nas $7^{\mathrm{a}}$. e $8^{\mathrm{a}}$. classes e em alguns casos até na $9^{\mathrm{a}}$. classe.

O ensino médio estava organizado em duas linhas ou opções de formação, cabendo neste caso ao candidato escolher o que melhor lhe convinha. Destas, uma estava voltada para a formação de técnicos médios num prazo de quatro anos, em cursos como técnico médio de saúde, economia, jornalismo, indústria, agronomia e de professores (pedagogia). A outra consistia em um ensino médio que tinha a duração de três anos (pré-universitário). Este tinha por objetivo preparar candidatos que queriam ingressar no ensino superior. A formação, nesta linha, era nas áreas de ciências sociais e exatas.

As dificuldades de aceso ao ensino médio, em grande parte, se davam também por falta de vagas suficientes, isto é, de infra-estruturas para atender ao número de candidatos que anualmente terminavam a oitava classe. Esta situação, que se repete em todas as províncias angolanas, devia-se, além da falta de infra-estruturas ou da situação de guerra, à falta de políticas de ampliação contínua destas estruturas escolares para que com isso se pudesse permitir aos alunos continuarem com os seus estudos - da $1^{\mathrm{a}}$. classe ao ensino médio sem necessidade de parar por falta de vagas. Como se pode notar, existe uma disparidade elevada (em números) desde a $1^{\mathrm{a}}$. classe ao ensino médio. Quanto maior ou mais elevado é o nível ou a classe, menor srá o número de vagas e 
menores são as possibilidades de acesso, e quanto menor for o nível escolar maior é o número de vagas e menores são as dificuldades de acesso.

Com a breve paz de 1991/2 Angola passou a registrar um pequeno crescimento de alunos no ensino médio, e este passou a estender-se também às províncias ou locais anteriormente de difícil acesso. De uma maneira geral podia verificar-se, segundo os dados apresentados por Conjimbi (2000, p. 180), na Tabela 12, de alunos matriculados nos anos de 1990/1-1997/8.

Tabela 12: Alunos matriculados por cursos no ensino médio 1990-1998

\begin{tabular}{|l|c|c|c|r|r|r|r|}
\hline \multirow{2}{*}{ Ano } & Curso & $\begin{array}{c}\mathbf{9}^{\mathbf{a}} \text {. } \\
\text { classe }\end{array}$ & $\begin{array}{c}\mathbf{1 0}^{\mathbf{a}} \text {. } \\
\text { classe }\end{array}$ & $\begin{array}{c}\mathbf{1 1}^{\mathbf{a}} \mathbf{} \\
\text { classe }\end{array}$ & $\begin{array}{c}\mathbf{1 2}^{\mathbf{a}} \text {. } \\
\text { classe }\end{array}$ & $\begin{array}{c}\text { Total/ } \\
\text { Curso }\end{array}$ & $\begin{array}{l}\text { Total/ } \\
\text { Geral }\end{array}$ \\
\hline \multirow{2}{*}{$1990 / 1$} & Técnico - & 5.045 & 2.879 & 1.973 & 1.037 & 10.934 & \multirow{2}{*}{20.310} \\
& pedagógico & 3.516 & 2.560 & 1.892 & 1.408 & 9.376 & \\
\hline \multirow{2}{*}{$1991 / 2$} & Técnico - & 4.589 & 4.169 & 2.367 & $?$ & 11.125 & \multirow{2}{*}{21.852} \\
& pedagógico & 3.524 & 2.978 & 2.509 & 1.716 & 10.727 & \\
\hline \multirow{2}{*}{$1992 / 3$} & Técnico & 2.588 & 2.541 & 1.630 & 904 & 7.663 & \multirow{2}{*}{10.980} \\
& pedagógico & 1.212 & 857 & 646 & 602 & 3.317 & \\
\hline \multirow{2}{*}{$1993 / 4$} & Técnico - & 5.828 & 3.565 & 2.217 & 1.385 & 12.995 & \multirow{2}{*}{20.874} \\
& pedagógico & 3.761 & 1.582 & 1.346 & 1.190 & 7.879 & \\
\hline \multirow{2}{*}{1996} & Técnico - & 5.983 & 4.111 & 3.780 & 1.890 & 15.742 & \multirow{2}{*}{24.338} \\
& pedagógico & 4.050 & 2.062 & 1.499 & 985 & 8.596 & \\
& Técnico - & 7.134 & 5.555 & 3.403 & 2.342 & 18.434 & \multirow{2}{*}{34.276} \\
& pedagógico & 7.168 & 4.705 & 2.284 & 1.667 & 15.842 & \\
& Técnico - & 9.640 & 6.510 & 4.578 & 2.719 & 23.447 & \multirow{2}{*}{37.667} \\
& pedagógico & 5.924 & 3.851 & 2.785 & 1.660 & 14.220 & \\
\hline
\end{tabular}

Fonte: Ministério da Educação. In: Conjimbi, 2000, p. 180.

Como se pode notar no quadro acima, nos anos de 1994 e de 1996 houve um crescimento elevado de alunos matriculados neste ensino. Este fato se deve à abertura de novas possibilidades de cursos médios nas províncias. Destes cursos destaca-se o técnico médio de economia, indústria, saúde e agronomia. As matrículas feitas no ano letivo de 1997/8 nas diversas áreas de cursos do ensino médio mostram o seguinte:

Tabela 13: Distribuição das matriculas 1997/8

\begin{tabular}{|c|l|r|r|r|r|r|}
\hline Curso & Províncias & $\mathbf{9}^{\mathbf{a}}$. cl. & $\mathbf{1 0}^{\mathbf{a}}$. cl. & $\mathbf{1 1}^{\mathbf{a}}$. cl. & $\mathbf{1 2}^{\mathbf{a}}$. cl. & \multicolumn{1}{c|}{ Total } \\
\hline \multirow{5}{*}{ Economia } & Kunene & 145 & 105 & 87 & 29 & 366 \\
& Huíla & 623 & 538 & 532 & 338 & 2.031 \\
& Luanda & 1.528 & 1.205 & 897 & 895 & 4.525 \\
& Bié & 103 & 93 & 51 & $?$ & 247 \\
\hline
\end{tabular}




\begin{tabular}{|l|l|r|r|r|r|r|}
\hline & Subtotal & $\mathbf{2 . 3 9 9}$ & $\mathbf{1 9 4 1}$ & $\mathbf{1 5 6 7}$ & $\mathbf{1 2 6 2}$ & $\mathbf{7 1 6 9}$ \\
\hline \multirow{5}{*}{ Indústria } & Benguela & 304 & 202 & 151 & 61 & 718 \\
& Luanda & 2.571 & 1.458 & 886 & 318 & 5.233 \\
& Lunda-Norte & 260 & 129 & 137 & 77 & 603 \\
& Subtotal & $\mathbf{3 . 1 3 5}$ & $\mathbf{1 . 7 8 9}$ & $\mathbf{1 . 1 7 4}$ & $\mathbf{4 5 6}$ & $\mathbf{6 . 5 5 4}$ \\
\hline \multirow{5}{*}{ Saúde } & Malanje & 248 & 268 & 178 & 111 & 805 \\
& Benguela & 399 & 261 & 260 & 121 & 1.041 \\
& Luanda & 197 & 570 & 480 & 326 & 1.573 \\
& Huíla & 175 & 211 & 71 & 117 & 574 \\
& Cabinda & 209 & 123 & 178 & 41 & 551 \\
& Bié & 373 & 219 & 163 & 88 & 843 \\
& Moxico & 222 & 123 & 94 & 76 & 515 \\
& Subtotal & $\mathbf{1 . 8 2 3}$ & $\mathbf{1 . 7 7 5}$ & $\mathbf{1 . 4 2 4}$ & $\mathbf{8 8 0}$ & $\mathbf{5 . 9 0 2}$ \\
\hline \multirow{5}{*}{ Egricultura } & Uíge & 195 & 119 & 40 & 12 & 366 \\
& Huíla & 130 & 96 & 53 & 33 & 312 \\
& Huambo & 264 & 216 & 87 & 41 & 608 \\
& Subtotal & $\mathbf{5 8 9}$ & $\mathbf{4 3 1}$ & $\mathbf{1 8 0}$ & $\mathbf{8 6}$ & $\mathbf{1 . 2 8 6}$ \\
\hline & Hotel. Turis. & 571 & 117 & 40 & 20 & 748 \\
& Pescas & 148 & 135 & 0 & 0 & 283 \\
& Petróleos & 290 & 337 & 84 & 63 & 774 \\
& Educ. Social & 350 & 110 & 78 & 49 & 587 \\
& Topografia & 217 & 0 & 0 & 0 & 217 \\
& Sub-Total & $\mathbf{1 . 5 7 6}$ & $\mathbf{6 9 9}$ & $\mathbf{2 0 2}$ & $\mathbf{1 3 2}$ & $\mathbf{2 . 6 0 9}$ \\
\hline
\end{tabular}

Fonte: Ministério da Educação. In: Conjimbi, 2000, p. 181-182.

Analisando a Tabela 13, depreende-se que o curso de economia abarca maior número de alunos matriculados, o que representa $31 \%$ do total de alunos matriculados; 64\% destes alunos concentram-se em Luanda (capital de Angola), onde está concentrado maior número de instituições escolares. Depois da economia está o curso médio voltado à indústria, que também conta com um número maior de alunos na capital do país.

Quanto ao gênero, o ensino médio é freqüentado na sua maioria por homens. Contudo existem províncias em que este quadro se reverte, como o caso do Namibe, em que as alunas representam quase 53,2\% do total, em Benguela, 55\%; e no Huambo, 60,5\%. Isso acontece pelo fato de que, depois de completados os dezoito anos, os homens eram levados a prestarem o serviço militar obrigatório - incorporação nas Forças Armadas. Nestas províncias, as buscas pelos jovens, para prestarem serviço militar obrigatório, eram mais freqüentes do que em outras províncias do de Angola. Esta situação fazia com que o número de rapazes seja menor no espaço escolar. Aqueles que não se enquadravam nas Forças Armadas, depois de dos dezoito anos ou desistiam por falta de documento militar (dispensa militar), ou por imposição do regulamento que 
impossibilita alunos de idade avançada matricular-se no ensino médio regular (diurno ou noturno).

A maioria dos alunos que terminava o ensino médio não conseguia dar continuidade aos estudos, primeiro pelo limitado número de vagas e de infra-estruturas universitárias, segundo por falta de condições sociais e de incentivos por parte do Estado. Outro fator é o caso, já apontado acima, da vida militar, em que grande parte dos jovens de sexo masculino eram enquadrados.

Outro aspecto constatado no ensino básico e que se repete no ensino médio é que, à medida que aumenta o nível escolar, diminui o número de alunos devido à reprovação, desistência e, às vezes, por não haver vagas suficientes no ano seguinte. $\mathrm{Na}$ Tabela 14 se pode notar, além da predominância do número maior de alunos que Luanda apresentava, o caso de províncias que não têm a continuidade nos quatro anos de ensino médio devido à falta de professores ou de estrutura (salas de aulas).

Tabela 14: Alunos do ensino médio normal por províncias

\begin{tabular}{|l|c|c|c|c|c|}
\hline Províncias/ classes & $\mathbf{9}^{\mathbf{a}} \mathbf{.} \mathbf{c l}$. & $\mathbf{1 0}^{\mathbf{a}}$. cl. & $\mathbf{1 1}^{\mathbf{a}} \mathbf{.} \mathbf{c l}$. & $\mathbf{1 2}^{\mathbf{a}}$. cl. & Total \\
\hline Cabinda & 119 & 401 & 356 & 142 & 1.018 \\
\hline Zaire & 269 & 49 & 0 & 0 & 318 \\
\hline Uíge & 172 & 117 & 88 & 51 & 428 \\
\hline Luanda & 1.252 & 597 & 318 & 275 & 2.442 \\
\hline Kwanza-Norte & 213 & 133 & 0 & 0 & 346 \\
\hline Kwanza-Sul & 266 & 157 & 118 & 85 & 626 \\
\hline Malanje & 273 & 67 & 224 & 170 & 734 \\
\hline Lunda-Norte & 159 & 495 & 57 & 38 & 749 \\
\hline Lunda-Sul & 332 & 74 & 53 & 0 & 459 \\
\hline Benguela & 722 & 294 & 497 & 301 & 1.814 \\
\hline Huambo & 452 & 433 & 192 & 97 & 1.174 \\
\hline Bié & 539 & 139 & 328 & 189 & 1.195 \\
\hline Moxico & 122 & 0 & 105 & 0 & 227 \\
\hline Kwando-Kubango & 115 & 273 & 164 & 77 & 629 \\
\hline Namibe & 304 & 269 & 196 & 168 & 937 \\
\hline Huíla & 267 & 8 & 41 & 29 & 345 \\
\hline Kunene & 24 & 73 & 48 & 38 & 183 \\
\hline Bengo & 124 & 0 & 0 & 0 & 124 \\
\hline TOTAL & $\mathbf{5 . 7 2 4}$ & $\mathbf{3 . 5 7 9}$ & $\mathbf{2 . 7 8 5}$ & $\mathbf{1 . 6 6 0}$ & $\mathbf{1 3 . 7 4 8}$ \\
\hline
\end{tabular}

Fonte: Ministério da Educação. In: Conjimbi, 2000, p. 183. 


\subsection{Ensino superior}

Este nível de ensino estava subdividido em bacharelado, do primeiro ao terceiro ano, com caráter terminal (três anos de duração), e a licenciatura no quarto ou quinto (quatro a cinco anos de duração). Para o instituto de formação de professores, previa-se a formação em dois níveis: bacharelado e licenciatura.

$\mathrm{O}$ ensino superior ${ }^{51}$ angolano dava-se em uma única universidade pública chama "Agostinho Neto" (em memória ao primeiro presidente de Angola) e um Instituto Superior voltado à área de Educação - ISCED (Instituto Superior de Educação). O funcionamento desta universidade concentra-se mais em Luanda e agrega vários ramos das ciências tais como; Direito, Economia, Ciências Agrárias, Engenharia e Medicina; o ISCED por sua vez estende-se às províncias de Huambo, Luanda, Benguela e Huíla.

Os dados de 1997/8 mostram-nos o número de alunos, homens e mulheres que freqüentavam o ensino superior.

Tabela 15: Ensino superior 1997/8 (divisão por sexo)

\begin{tabular}{|l|r|r|r|}
\hline \multicolumn{1}{|c|}{ Faculdade } & Homens & Mulheres & Soma \\
\hline Ciências & 397 & 268 & 665 \\
\hline Ciências Agrárias & 190 & 110 & 300 \\
\hline Direito & 589 & 302 & 891 \\
\hline Economia & 670 & 445 & 1.115 \\
\hline Engenharia & 486 & 135 & 621 \\
\hline Medicina & 242 & 262 & 504 \\
\hline ISCED & 2.241 & 1.577 & 3.818 \\
\hline Benguela & 327 & 219 & 546 \\
\hline Huambo & 381 & 248 & 629 \\
\hline Luanda & 891 & 814 & 1.705 \\
\hline Huíla & 642 & 296 & 938 \\
\hline
\end{tabular}

Fonte: Conjimbi, 2000, p. 184.

\footnotetext{
${ }^{51}$ Além da província de Luanda, onde a Universidade Agostinho Neto concentra maior número de cursos, há também institutos ou pólos, nas províncias de Benguela, Kwanza Sul, Cabinda, Huambo, Huila, Namibe e Uige. As universidades e faculdades particulares (surgem depois de 1992) estão na sua maioria, também, concentradas em Luanda.
} 
Segundo Conjimbi (2000, p. 184) o número total dos estudantes que estavam matriculados no ensino superior "é relativamente baixo se tivermos em conta que há 54 estudantes para 100.000 habitantes". Outro aspecto fundamental a ser observado é o fato de que "seis faculdades e um Instituto Superior estão em Luanda. A maior parte dos 35 cursos $(82,9 \%)$ da Universidade Agostinho Neto e todas as áreas das Ciências Exactas e Tecnologias, também estão em Luanda". Outro problema que, também afeta o ensino superior, é referente ao número de alunos matriculados e o dos que, efetivamente, conseguem concluir o curso. Calcula-se que para cada cinco estudantes que ingressam no ensino superior um ou dois destes chega a obter o diploma. Os demais param antes por falta de condições econômicas ou por desistência ou falta de professores em algumas cadeiras (disciplinas) e, em outros casos, por reprovação.

\subsection{Alfabetização e ensino de adultos}

Os propósitos principais sobre os quais assenta a necessidade da existência deste subsistema de ensino de adultos e da alfabetização são a recuperação do atraso escolar aos quais, no devido momento, faltaram as possibilidades de freqüentarem o ensino formal; a erradicação do analfabetismo; "elevação" do nível de ensino e da formação da população economicamente ativa. Pretende-se ainda, com este tipo de ensino, atender as exigências da universalização da educação básica e a sua obrigatoriedade.

Segundo o Ministério da Educação (Plano de acção nacional de educação para todos, 2004, p. 13) as tarefas e objetivos do subsistema de ensino de adultos e alfabetização estruturam-se fundamentalmente em duas formas:

1. A Formação de Base: esta integra as ações orientadas para a "aquisição de competência de leitura, escrita, interpretação e cálculo, bem como para a satisfação das necessidades pessoais e sociais, pelo que as acções a desenvolver poderão ter como finalidade a alfabetização em sentido estrito, por forma a permitir o acesso a conhecimentos e competências, só possível através de uma educação de base que não se circunscreve à leitura e à escrita" (Ministério da Educação 2004, p. 13); 


\section{Os Projetos de Animação Social e Desenvolvimento Comunitário:}

estes representam um "eixo privilegiado do desenvolvimento e da mobilização de grupos sociais de base local, numa dinâmica de resolução de problemas comunitários e de concretização de projectos próprios" (Ministério da Educação 2004, p. 13).

Tal como no ensino normal regular, este subsistema de ensino e alfabetização de adultos também enfrenta dificuldades, como falta de estruturas suficientes para atender a procura daqueles que necessitam passar por este subsistema e falta de professores com formação para atender a esta situação que surge, justamente, da falta de eficiência e pouca abrangência nacional do sistema de ensino normal implementado no país depois da independência colonial.

De acordo com o Ministério da Educação, os problemas enfrentados devem-se ao "limitado acesso às oportunidades educativas, à baixa qualidade e finalmente os elevados custos da expansão do acesso e da melhoria da qualidade" (MEC, 2004, p. 14. Vol. 5). Contudo, mais uma vez aqui é importante indagar se, realmente, o problema deve-se, simplesmente, ao custo elevado ou se a resolução deste problema não representa para o Estado alguma preocupação maior comparada, por exemplo, ao investimento feito nas forças armadas ou ás verbas destinadas à estrutura central do Estado (ver Tabela 2).

Em grande parte, o trabalho de alfabetização de adultos tem sido realizado de acordo com a política de alianças, por Organizações Não-Governamentais (ONG's) e por instituições religiosas. Estas organizações nem sempre ou quase nunca recebem apoio financeiro do Estado para tal intento. O Estado tem se limitado ao papel de "acompanhamento" e ao de "avaliação". As ONGs ou instituições religiosas envolvidas na educação e alfabetização de adultos e os seus recursos provêm de doadores ou financiamentos de instituições que ajudam atividades sociais ou de recursos próprios.

Um outro aspecto também contraditório do discurso é que o ensino e alfabetização de adultos é feita, na maior parte, nos períodos noturnos e, em alguns casos, no período vespertino por se tratar de trabalhadores e pais de famílias. Todavia, a grande maioria destas escolas carece de energia elétrica, o que faz com que em vários 
estabelecimentos de ensino, não haja aulas por falta de luz elétrica. Este problema, da ausência da luz elétrica, também afeta alunos regulares, que, devido ao excesso (demanda) nas escolas em relação à oferta, não puderam ser enquadrados no período normal (diurno), passando então a estudar de noite. Outra situação ainda mais preocupante é que, como o Ministério da Educação aponta (2004);

\footnotetext{
Em termos de docência, o Subsistema da Educação de Adultos sobrevive da colaboração docente que na pós-alfabetização, quer no II e III níveis, não tendo professores específicos, estendendo-se igualmente essa situação ao processo de alfabetização devido às suas características de amplo movimento sócio-educativo. As habilitações literárias ${ }^{52}$ médias dos docentes da Educação de Adultos é a oitava classe no meio urbano, a sexta classe nas áreas periurbanas e a quarta classe no meio rural (Ministério da Educação, 2004, p. 14. Vol. 5).
}

Segundo os dados de pesquisa apresentados pelo Ministério da Educação, o subsistema - educação de adultos e alfabetização - apresenta um rendimento muito baixo. Nota-se um abandono de aproximadamente 20\%, uma reprovação de $25 \%$ ou mais e uma repetência de $15 \%$ ou mais, sendo que, dos matriculados no início de cada ano letivo, menos da metade consegue chegar ao final do ano letivo. Foi criado o Instituto Nacional de Educação de Adultos (INEDA) para poder tratar do problema da alfabetização, porém, nos últimos anos, o Estado tem procurado adotar novas medidas em relação à questão da alfabetização e ensino de adultos. Estas medidas têm consistido mais na ausência do que na presença do Estado, diante do problema do analfabetismo dos adultos, pois estas medidas visam atribuir maior responsabilidade às ONGs ou organizações religiosas na tarefa de erradicação do analfabetismo em Angola.

Como aponta o documento do Ministério da Educação que trata da estratégia integrada para a melhoria do ensino e da revitalização da alfabetização, a partir de 8 de setembro de 1997, o Ministério da Educação e Cultura tem vindo a “implementar com sucesso à escala nacional, a nova estratégia da alfabetização e o processo de reorganização de adultos, assento na política de alianças, consubstanciada na participação e responsabilização dos parceiros sociais” (MEC, 2004, p. 15) na

\footnotetext{
${ }^{52}$ Nível acadêmico ou de escolarização do professor.
} 
concretização de programas voltados à alfabetização e ensino de adultos. O Estado tem assumido desta forma um papel de controlador, estabelecendo normas de atuação para as instituições não governamentais que atuam no ensino de adultos e programas de alfabetização. A política e estratégia de alfabetização e a educação básica de adultos foi repensada, como afirma o Ministério da Educação (2004)

\footnotetext{
à luz da nova realidade política, econômica e social, tendo o Estado deixado de ser o principal protagonista, isto é fazer tudo por todos, remetendo-se ao papel de reitor, de orientador, de formador de formadores, de promotor, de regulador, de catalisador, de fomento, de desenvolvimento, de fiscalizador e de o único certificador de conhecimentos - emissão de certificados (Ministério da Educação, 2004, p. 15. Vol. 5).
}

Existe por detrás desta nova política o objetivo de levar os terceiros à responsabilidade como empregadores e tutores de pessoas analfabetas, sobretudo daqueles que se encontram em idade economicamente ativa. Este intento é justificado pelo Estado que, a longo prazo, prevê a extinção de disponibilidades de infra-estruturas públicas para a satisfação das necessidades daqueles que não puderam ser alfabetizados (Ministério da Educação, 2004, p. 15. Vol. 5). Pode-se ainda destacar, segundo o Ministério da Educação, que, de todas as atividades voltadas para a alfabetização de adultos, $70 \%$ são asseguradas por iniciativas de parceiros terceiros (organismos sociais) e instituições religiosas, ficando o Estado com o papel de certificador de "conhecimentos".

Fazendo uma comparação entre homens e mulheres, nota-se que o número maior de analfabetos é do sexo feminino e, por se tratar de adultos, isto tem uma repercussão grande dentro da família, em termos de cuidados primários de saúde como o cuidado da nutrição, saneamento básico, mortalidade infantil, além de outras situações que, como se sabe, requerem do Estado uma política social mais abrangente, que permita melhorar a qualidade de vida e mudar os índices de desenvolvimento humano. De forma geral o índice de analfabetismo é calculado em $60 \%$, sendo que, deste total, os homens representam uma percentagem menor comparada a das mulheres. Os adolescentes e jovens que se encontram na mesma situação de analfabetos representam $56 \%$ do total dos inscritos anualmente para a alfabetização e ensino de adultos. 
Desde o período em que foi lançado o programa da Campanha Nacional de Alfabetização (22 de novembro de 1976) até ao ano de 2000, segundo os dados do Ministério da Educação (2004, p. 16. Vol. 5), "foram alfabetizados em todo o país, 2.827.279 cidadãos, dos quais cerca de $48 \%$ são mulheres”. O fator que fez com que o número dos alfabetizados fosse reduzido deve-se a várias situações que, como destaca o Ministério da Educação, resultam do contexto político militar em que o país se encontrava. Entre outros fatores destacam-se:

- A generalização da instabilidade político-militar que provocou o movimento migratório das populações em busca de segurança e sobrevivência e o conseqüente impedimento de equipas de alfabetizadores a muitas áreas rurais onde o analfabetismo é mais intenso;

- A recessão económico-financeira e a inadaptação às transformações políticas, económicas e sociais, consubstanciadas na adopção do multipartidarismo e da economia de mercado, estando na origem do desaparecimento do espírito de voluntariado no qual o programa da alfabetização se tinha baseado;

- Metodologias de ensino desajustadas à psicologia de aprendizagem do adulto (muito formais e acadêmico);

- Fraca pertinência social dos conteúdos educativos e sem relação proporcionalmente directa com a vida sócio-econômica e profissional dos grupos-alvo (sem expressão funcional);

- Débil expansão e generalização da alfabetização em línguas nacionais particularmente no meio rural;

- Ausência da pós-alfabetização em línguas nacionais;

- Atenção insuficiente à pós-alfabetização, como etapa de consolidação da alfabetização, particularmente no meio rural, onde os materiais de leitura são escassos ou inexistentes 53 .

Em suma, o analfabetismo é mais elevado nas áreas rurais do que nas cidades e províncias costeiras. As províncias que apresentam menor índice de analfabetismo são: Benguela, Cabinda Huila e Luanda; as que apresentam um índice maior são: Zaire Bengo, Moxico, Lunda-Norte e Sul, Bié Cunene e Kuando Kubango. A implementação de projetos de ensino e alfabetização de adultos poderá requer maior esforço político e social, pois, com o fim da guerra, a concentração de pessoas nas cidades poderá ser maior, o que exigirá projetos socioculturais amplos de socialização.

\footnotetext{
${ }^{53}$ Ministério da Educação e Cultura, 2004, p. 16-17, vol. 5.
} 


\section{CAPÍTULO IV}

\section{SEGUNDA REFORMA DO SISTEMA EDUCACIONAL (LEI $\mathrm{N}^{\mathrm{O}}$. 13/2001): DESENVOLVIMENTO E PERSPECTIVAS}

\section{1 - Da concepção da necessidade da reforma educacional}

As primeiras idéias e reflexões que apontavam a necessidade da reforma educacional surgiram logo depois do diagnóstico realizado no ensino básico (implementado em 1978) em 1986. O diagnóstico apontava vários aspectos negativos, que se constatavam freqüentemente no ensino escolar, concernentes ao fraco aproveitamento escolar dos alunos, nos diferentes níveis de ensino e localidades do país, e do pouco preparo dos docentes que atuavam nas escolas.

O diagnóstico apontava também as fraquezas do ensino básico como um dos fatores de estrangulamento do sistema educacional. Dentre essas fraquezas ressaltava-se que o "Sistema de Educação sofria sobremaneira os efeitos da guerra e enfermava de profundas distorções nos seus principais dispositivos" tais como: “currículos, processo de ensino e aprendizagem, corpo docente, corpo discente, administração e gestão, e recursos materiais" ${ }^{\text {54 }}$. O mesmo relatório do diagnóstico aponta ainda que as distorções derivavam dos erros de concepção e implementação das mudanças (reformas) que pretendiam conduzir à extinção do Sistema de Ensino Colonial.

Um dos pontos também apontados pelo diagnóstico era de que os objetivos que o sistema educacional, implementado em 1978, pretendia alcançar em menos tempo eram demasiado ambiciosos, dadas as condições em que o país se encontrava, em termos de desenvolvimento econômico, político, social e cultural, sobretudo dos recursos que o Estado destinava ao setor administrativo e de gestão. Os recursos, em termos gerais, eram muito insuficientes diante das necessidades e demanda

\footnotetext{
${ }^{54}$ Ministério da Educação. Cronograma e estratégia de implementação da Lei de Bases do sistema de educação. Luanda, 2004, vol. 6.
} 
no ensino. Em função desta situação o relatório do diagnóstico recomendava a necessidade de um estudo e análise mais apurados das anomalias que se vinham registrando no ensino em vigor em Angola, com o objetivo de tentar, a partir daí, estabilizar o Sistema Educacional e procurar refletir sobre a concepção de uma nova estrutura do Sistema Educacional.

Conforme declarava o documento do Ministério da Educação, no seu relatório sobre estratégia de implementação do novo sistema de educação, no item quatro:

Em cumprimento da orientação superior do Poder Político em 1986 que aprovava as conclusões e as recomendações [...] descritas, foram então implementadas algumas medidas correctivas, realizados estudos e executados projectos de desenvolvimento, alguns dos quais focalizados em domínios específicos dos diferentes níveis de ensino. Por outro lado, foram igualmente iniciadas acções destinadas a aprofundar a concepção de uma nova estrutura do Sistema de Educação (Ministério da Educação, 2004, p. 27. Vol. 6)

Desde então (1986) tem-se vindo a recolher opiniões que pudessem, aos poucos, fundamentar as opções até aqui realizadas (reformas) no ensino. Outros debates foram realizados em função do projeto de lei geral de educação angolana. Vários debates ainda precisam ser feitos, em termos políticos e culturais, dadas as opções do "pluralismo do sistema político e da economia do mercado", que impuseram "um ritmo mais lento na implementação da Reforma Educativa, pois tornou-se necessário adequar alguns princípios e objetivos gerais do Sistema de Educação, então na forja" (Ministério da Educação, 2004, p. 27).

Diferente das mudanças (reforma) ocorridas em 1977 no sistema de ensino, posto em vigor desde abril de 1978, a atual reforma está tentando seguir um rumo e metodologia diferentes. Isto se nota desde a mesa redonda realizada em 1993 sobre o anteprojeto de Lei de Base do Sistema de Educação -, que ajudou na análise dos vários pareceres sobre o projeto de reforma, visando à constituição de uma lei que possa constituir o fundamento legal e principal das atividades a serem realizadas posteriormente no quadro das mudanças educacionais em Angola. 


\section{2 - Reforma e investimento financeiro em educação}

A idéia da aprovação da Lei $n^{0}$. 13/01 de 31 de dezembro - o fundamento legal das atividades da reforma educativa - parte de uma mesa redonda realizada em 1993, sobre o anteprojeto de Lei de Bases do Sistema de Educação, que contou com a contribuição de pareceres que pudessem ajudar na criação do novo sistema de ensino. Partiu da idéia de reorganizar a estrutura básica de ensino, do ponto de vista administrativo, econômico, social, cultural e do seu currículo escolar (conteúdo), pois, com a assinatura dos $\operatorname{acordos}^{55}$ de paz entre a UNITA e o MPLA e do surgimento do multipartidarismo, havia a necessidade de mudar o sistema de ensino que até então estava pautado na visão de partido único (MPLA) para dar lugar a outras perspectivas de tolerância, unidade nacional, inserir princípios de democracia, liberdade política e cultural no sistema educacional. A reforma visa também atender a política de educação para todos, proposta pela UNESCO como um dos objetivos do milênio (até 2015), e contribuir para a melhoria do IDH (Índice de Desenvolvimento Humano).

Quanto ao financiamento em educação, a lei aprovada não esclarece o quanto deve ser destinado à educação ou à reforma educacional que se pretende realizar até o ano de 2015, isto é, a lei não traz um artigo que diz qual percentagem anual deve ser destinada ao ensino. O que é destinado à educação, assim como a outras áreas de saúde, agricultura, etc. depende da aprovação anual do Orçamento Geral do Estado. Os dados de 2003 a 2006 (Tabela 16) permitem-nos perceber esta variação dos gastos do Estado na área de educação.

Todavia, o documento final da Consulta Pública Nacional, atinente ao projeto de "Acção Nacional de Educação para Todos" (ANET), que resultou do encontro realizado entre 21 e 24 de abril de 2004 no Palácio dos Congressos (Luanda), apontou, entre outros, aspectos relacionados ao financiamento em educação, saúde e a inserção social como uma das áreas que devem merecer especial atenção do Estado angolano. O documento visa também alargar o debate sobre a educação de Angola até ao ano de 2015, mobilizar o envolvimento de várias instituições públicas e privadas na

\footnotetext{
${ }^{55}$ Assinatura do Acordo de Bicesse. Houve a participação de Portugal, URSS e dos Estados Unidos da América (observadores). No dia 15 de maio de 1991, Lopo do Nascimento (MPLA) e Jeremias Chitunda (UNITA) rubricaram os acordos sob observação de Portugal, na pessoa de Durão Barroso. Dezesseis dias depois das duas forças terem aceitado o cessar-fogo e as normas de convivência, a constituição de um exército único e a marcação de eleições multipartidárias para 1992, o presidente Jose Eduardo dos Santos (MPLA) e Jonas Savimbi (Presidente da UNITA) assinaram o acordo de paz para Angola.
} 
política de implementação da educação para todos e refletir as formas de implementação dos objetivos e estratégias mediante as condições que o país apresenta de acordo com a nova lei educacional.

Do encontro resultou o documento que aponta vários aspectos que necessitam ser superados tais como:

1. Insuficiência de recursos financeiros para a gestão do sistema de ensino;

2. Falta de incentivos para a retenção e mobilidade geográfica do corpo docente no sistema de Educação e Ensino;

3. Fraco domínio da Língua veicular pelos alunos e a língua nacional pelos professores;

4. Deficiente promoção da cultura de cidadania;

5. Insuficientes estruturas infantis de atendimento à primeira infância;

6. Fraca utilização da língua gestual no sistema de educação e Ensino;

7. Não utilização das línguas nacionais no processo de ensino e aprendizagem;

8. Contexto sócio-económica e cultural em que vivem as famílias e comunidades que não permite uma participação activa nas questões de protecção, educação e desenvolvimento das crianças na primeira infância;

9. Inexistência de programas educativos rádio televisionados em língua portuguesa, nacionais e gestual;

10. Insuficiência de infra-estruturas físicas e material escolar (Ministério da Educação. Documento final. 21 a 24 de abril, 2004).

As conclusões dos trabalhos realizados no encontro da discussão do projeto de Educação Para Todos aponta para a necessidade de atenção do governo em relação ao sistema nacional de educação. Constatados os aspectos que necessitam maior atenção por parte dos órgãos competentes (Ministério da Educação, governo nacional e provincial, etc), foram aprovadas algumas recomendações para a melhoria do ensino nacional.

Dos pontos recomendados pela equipe que participou do encontro podemos apresentar alguns, para melhor entendimento da nossa abordagem, tais como:

1. Melhoramento da gestão dos recursos humanos e realizar, em vários níveis, fóruns periódicos sobre a primeira infância;

2. Construção e apetrechamento de escolas primárias;

3. Construção de residências para professores nas zonas rurais; 
4. Que sejam respeitados os critérios e normas em vigor para o funcionamento das Direções Provinciais de Educação em adequação com a estrutura do MED;

5. Estabelecimento de uma norma que possibilite a melhoria da coordenação das agências financiadoras e ONGs que trabalham no sector;

6. Estudo das populações nómadas para a identificação das melhorias práticas educativas para o ensino das crianças das respectivas comunidades;

7. Reforço das capacidades dos centros de formação local para que possam implementar os diferentes programas e modalidades de formação de professores, formadores e gestores escolares;

8. Que o registo educacional das crianças a partir dos 5 anos seja feito por brigadas mistas integradas por agentes da educação e da justiça;

9. Implementação da política de incentivos para a retenção do corpo docente no sistema de educação e ensino particularmente nas zonas rurais;

10. Elaboração e implementação urgente de programas curriculares em línguas nacionais por forma a proporcionar o desenvolvimento da educação e formação profissional dos jovens e adultos sobretudo os que vivem nas zonas rurais;

11. Reforço na aprendizagem da língua portuguesa para possibilitar a formação integral;

12. Criação de áreas de formação e cursos de acordo com as necessidades nacionais, sectoriais e revisão dos currículos de formação, no sentido de se atribuir maior carga horária às praticas e as experiências profissionais;

13. Criação e implementação de um sistema flexível de formação em regime de alternância que proporcione a preparação e a entrada de jovens na vida activa, sem descorar as possibilidades de integração no setor informal de economia;

14. Incremento da alfabetização em línguas nacionais e do ensino a distância;

15. Estudo da possibilidade de uma melhor aplicação da modalidade do ensino informal;

16. Garantia de distribuição do material escolar;

17. Criação e apetrechamento de bibliotecas escolares;

18. Promoção da cultura de paz e da tolerância, a educação da cidadania e a educação patriótica como pressuposto importante para a edificação de um futuro melhor para todos os angolanos (Ministério da Educação. Documento final. 21 a 24 de abril, 2004).

Foi a partir de janeiro de 2003 que o Estado angolano traçou um programa, no qual encontram-se, entre outros objetivos, a consolidação da paz e melhoria da educação. O programa específico para 2003 na área social prevê a extensão da rede dos serviços de ensino $\left(1^{\mathrm{a}}\right.$. à $6^{\mathrm{a}}$. classe) a todas as comunidades e localidades do país; melhoria da qualidade de ensino; formação de competências técnico-profissionais no domínio da educação e ensino; e promoção da criação de infra-estruturas desportivas 
e culturais e centros cívicos comunitários (Diário da República de Angola, 07/01/2003, p. 10).

Em termos de infra-estruturas para o setor educacional, foram traçadas as seguintes metas: desenvolvimento do ensino primário, ensino secundário, ensino médio e pré-universitario, ensino de extensão universitária, ensino de graduação, ensino de pós-graduação, ensino especial, ensino profissional, aquisição do material escolar, alfabetização nacional, bolsas de estudo, educação militar, melhoria da qualidade de ensino, livro escolar e material didático, produção de cadernos escolares, recrutamento e formação de professores e reestruturação da Universidade Agostinho Neto (Diário da República de Angola, 07/01/ 2003, p. 10).

No âmbito local (nas províncias), as perspectivas do Estado eram de implementar, no período de 2003 e 2004, programas que poderiam contribuir no fortalecimento e melhoria da oferta de serviços sociais. Destes programas, os projetos para a área de educação nas províncias estava organizado da seguinte maneira: para a província de Cabinda previa-se a reabilitação e construção de escolas e habitações para professores. Para a província do Zaire o projeto traçado para o setor educacional visava a construção de 25 escolas e 17 casas para professores. Para a província do Uíge, a reabilitação de escolas do primeiro nível em todos os municípios, a reabilitação de escolas do segundo e terceiros níveis nos municípios de Negage, Maquela do Zombo, Sanza Pombo e Uíge, a construção de escolas do primeiro nível nas aldeias mais populares. Para a província de Malange o projeto visava a construção de um centro de formação local, a construção de 27 escolas do primeiro nível e duas do segundo, a reabilitação das vinte escolas do primeiro nível e cinco do segundo nível assim como a aquisição do material didático (Diário da República de Angola, 07/01/ 2003, p.12).

Para as províncias de Cunene, Huíla, Namibe e Luanda o projeto previa também a construção e reabilitação de escolas, porém não está discriminado o número das respectivas escolas e habitações para professores. Ainda segundo o Diário da República (2003), para a província de Benguela o projeto apresentava a construção de 58 escolas do primeiro nível e 10 do segundo. Apontava também a perspectiva de construção de 4 escolas do primeiro e segundo nível, 12 do terceiro nível, uma do primeiro, segundo e terceiro nível, 3 centros pré-universitários, reabilitação de lares de estudantes do ensino médio e do instituto médio de indústria e a construção de 50 residências para professores (Diário da República, 07/01/2003, p. 16). 
Para a província do Huambo o projeto prevê a construção, reabilitação e ampliação de 87 escolas do primeiro e segundo nível e a construção de 180 escolas comunitárias do primeiro nível; para a província do Bié a construção de 9 escolas do primeiro nível e a reconstrução de uma do segundo e terceiro nível. Para a província do Moxico pretendia-se reabilitar treze escolas; na província do Cuando Cubango a construção de vinte e seis escolas e reabilitação de duas do primeiro nível e aumento de quatro salas de aulas na escola do primeiro nível de São José.

Segundo o Art.1 do Capítulo primeiro da Lei do Orçamento Geral do Estado para 2003, as receitas aprovadas para despesas, em todas as áreas do país, foram de $358888331816,00 \mathrm{Kz}^{56}$ (Lei n. ${ }^{\circ} 2 / 03$ de 07 de janeiro). De acordo com o Art.1 o Orçamento Geral do Estado é “integrado pelos orçamentos dos órgãos da administração central e local do estado e pelos subsídios e transferências a realizar para os institutos públicos, serviços e fundos autônomos, empresas públicas e instituições de utilidade pública" (Diário da República 07/01/2003, p. 21). Para o ano de 2004 as receitas aprovadas foram de 665.347.988.813,00 Kz (Lei n. ${ }^{\circ}$ 29/03 de 30 de dezembro) e para o ano de 2006 foram de 2.176.922.260.474,00 Kz (Lei n. ${ }^{\circ} 17 / 05$ de 30 de dezembro) ${ }^{57}$. Do resumo das despesas dos três anos apontados, constata-se a seguinte distribuição:

Tabela 16: Resumo das despesas por função, de 2003 a 2006 (\%)

\begin{tabular}{l|r|r|c|r}
\hline Áreas / Ano & $\mathbf{2 0 0 3}$ & $\mathbf{2 0 0 4}$ & $\mathbf{2 0 0 5}$ & $\mathbf{2 0 0 6}$ \\
\hline Agricultura, pescas e ambiente & 1,19 & 0,76 & $?$ & 4,18 \\
Combustíveis e energia & 0,69 & 1,82 & $?$ & 1,91 \\
Comércio e serviços & 0,75 & 0,09 & $?$ & 0,25 \\
Cultura e desporto & 0,76 & 0,6 & $?$ & 0,25 \\
Defesa nacional & 7,6 & 12,03 & $?$ & 5,86 \\
Educação & $\mathbf{6 , 2 4}$ & $\mathbf{1 0 , 4 7}$ & $\mathbf{?}$ & $\mathbf{3 , 4 2}$ \\
Encargos financeiros & 38,81 & 27,77 & $?$ & 9,08 \\
Habitação e serviços comunitários & 1,57 & 3,07 & $?$ & 6,51 \\
Indústria e mineração & 0,11 & 0,08 & $?$ & 0,07 \\
Outros serviços econômicos & 1,43 & 1,78 & $?$ & 0,75 \\
Saúde & 5,82 & 5,69 & $?$ & 4,42 \\
Segurança e assistência social & 1,47 & 4,3 & $?$ & 9,75 \\
Segurança e ordem pública & 9,86 & 10,6 & $?$ & 6,71 \\
Serviços públicos gerais & 19,3 & 19,28 & $?$ & 31,16 \\
Transportes e comunicações & 4,4 & 1,66 & $?$ & 15,68 \\
Total & $\mathbf{1 0 0 \%}$ & $\mathbf{1 0 0 \%}$ & $\mathbf{?}$ & $\mathbf{1 0 0 \%}$ \\
\hline
\end{tabular}

Fonte: Diário da República de 07 de janeiro e 30 de dezembro de 2003 e de 30 de dezembro de 2005.

\footnotetext{
${ }^{56}$ Moeda de Angola. Um dólar americano equivale a 85 ou 90 Kwanzas, dependendo do câmbio do dia.

${ }^{57}$ Não tivemos acesso ao Diário da República que traz o Orçamento Geral do Estado aprovado para o ano de 2005. Os dados aqui disponíveis são aqueles aos quais pudemos conseguir ter acesso.
} 
Tabela 17: Distribuição das despesas nas áreas de educação, 2003 a 2006

\begin{tabular}{l|r|r|r|r}
\hline Áreas de ensino & $\mathbf{2 0 0 3}$ & $\mathbf{2 0 0 4}$ & $\mathbf{2 0 0 5}$ & $\mathbf{2 0 0 6}$ \\
Educação pré-escolar & 0 & 0 & $?$ & 0 \\
Ensino primário & 0,78 & 0,49 & $?$ & 1,39 \\
Ensino secundário & 0,14 & 0,42 & $?$ & 0,72 \\
Ensino de adultos & 0,15 & 0 & $?$ & 0 \\
Ensino técnico-profissional & 0,44 & 0,36 & $?$ & 1,16 \\
Ensino superior & 0,74 & 0,68 & $?$ & 0,38 \\
Outros serviços de educação & 3,99 & 8,52 & $?$ & 0,17 \\
Total (\%) & $\mathbf{6 , 2 4}$ & $\mathbf{1 0 , 4 7}$ & & $\mathbf{3 , 8 2}$ \\
\hline
\end{tabular}

De forma detalhada o gasto dos 6,24\% aprovados pelo Orçamento Geral do Estado para a educação em 2003, ficou distribuído da seguinte forma:

Tabela 18: Despesa por função e programa para a educação, 2003

\begin{tabular}{l|r}
\hline \multicolumn{1}{c|}{ Áreas de ensino / Programa } & Gastos 2003 (\%) \\
Ensino Primário & $\mathbf{0 , 7 8}$ \\
Construção e Reabilitação de Escolas Primárias & 0,62 \\
Desenvolvimento do Ensino Primário & 0,04 \\
Equipamento e Apetrechamento de Escolas Primárias & 0,12 \\
Ensino Secundário & $\mathbf{0 , 1 4}$ \\
Construção e Realibitação de Escolas Secundárias & 0,11 \\
Desenvolvimento de Ensino Secundário & 0 \\
Equipamento e Apetrechamento de Escolas Secundárias & 0,03 \\
Ensino técnico profissional & $\mathbf{0 , 4 4}$ \\
Construção e Realibitação de Escolas Médias-técnicas & 0,08 \\
Desenvolvimento do Ensino Médio-técnico & 0,19 \\
Equipamento e Apetrechamento de Escolas Médias-técnicas & 0,09 \\
Desenvolvimento do Ensino Profissional-Básico & 0,08 \\
Educação de adultos & $\mathbf{0 , 1 5}$ \\
Programa Nacional de Alfabetização & 0,15 \\
Ensino Superior & $\mathbf{0 , 7 4}$ \\
Desenvolvimento do Ensino de Graduação & 0,35 \\
Bolsas de Estudo & 0,25 \\
Reestruturação da Univ. Agostinho Neto & 0,14 \\
Outros serviços de Educação & $\mathbf{3 , 9 9}$ \\
Formação de Professores & 0,21 \\
Desenvolvimento do Ensino Especial & 0,01 \\
Melhoria da Qualidade de Ensino & 0,05 \\
Merenda Escolar & 0,02 \\
Operação Carteira, Livro Escolar/ Mat. Didático & 0,41 \\
Recrutamento e Formação de Professores & 0,02 \\
Reforma Educativa & 0,01 \\
Gestão da Política de Educação e Cultura & 3,27 \\
Aquisição de Material Escolar & 0 \\
\hline &
\end{tabular}

Fonte: Diário da República Angola. I ${ }^{\mathrm{a}}$ Série, nº 1.7 de janeiro de 2003, p. 45. 
Não muito diferente do ano anterior, os gastos (10,47\% aprovados pelo OGE) para a educação em 2004, foram distribuídos da seguinte maneira.

Tabela 19: Despesa por função e programa para a educação, 2004

\begin{tabular}{|c|c|}
\hline Áreas de Ensino / Programa & Gastos 2004 (\%) \\
\hline $\begin{array}{l}\text { Ensino Pimário } \\
\text { Construção e Reabilitação de Escolas Secundárias } \\
\text { Construção e Reabilitação de Escolas Primárias } \\
\text { Desenvolvimento e Expansão da mineração } \\
\text { Desenvolvimento do Ensino Primário } \\
\text { Equipamento e Apetrechamento de Escolas Primárias } \\
\text { Escola para Todos }\end{array}$ & $\begin{array}{r}0,42 \\
0 \\
0,35 \\
0,01 \\
0,04 \\
0,05 \\
0,04\end{array}$ \\
\hline $\begin{array}{l}\text { Ensino Secundário } \\
\text { Construção e Realibitação de Escolas Secundárias } \\
\text { Desenvolvimento de Ensino Secundário } \\
\text { Reforma Educativa }\end{array}$ & $\begin{array}{r}0,42 \\
0,37 \\
0,4 \\
0\end{array}$ \\
\hline $\begin{array}{l}\text { Ensino técnico profissional } \\
\text { Construção e Realibitação de Escolas Médias-Técnicas } \\
\text { Constr. e Reabilitação de Escolas de Graduação e Pós-Graduação } \\
\text { Desenvolvimento do Ensino Profissional-Básico } \\
\text { Desenvolvimento do Ensino Médio-Técnico } \\
\text { Equipamento e Apetrechamento de Escolas Médias-Técnicas } \\
\text { Formação de Professores } \\
\text { Gestão da Política de Educação e Cultura } \\
\text { Reabilitação da Infra-estruturas institucionais } \\
\text { Valorização da Mão-de-obra Nacional } \\
\text { Escolas para Todos }\end{array}$ & $\begin{array}{r}0,36 \\
0,05 \\
0,01 \\
0,12 \\
0,14 \\
0 \\
0 \\
0 \\
0,01 \\
0,01 \\
0,01\end{array}$ \\
\hline $\begin{array}{l}\text { Educação de adultos } \\
\text { Programa Nacional de Alfabetização }\end{array}$ & \\
\hline $\begin{array}{l}\text { Ensino Superior } \\
\text { Bolsa de Estudo } \\
\text { Constr. e Reabilitação de Escolas de Graduação e Pós-Graduação } \\
\text { Desenvolvimento do Ensino de Extensão Universitária } \\
\text { Desenvolvimento do Ensino de Graduação }\end{array}$ & $\begin{array}{l}0,68 \\
0,19 \\
0,05 \\
0,04 \\
0,33\end{array}$ \\
\hline $\begin{array}{l}\text { Outros serviços de educação } \\
\text { Articulação do Sist. de Segurança Contra a Nova Forma de Terrorismo } \\
\text { Desenvolvimento do Ensino de Graduação } \\
\text { Desenvolvimento do Ensino Especial } \\
\text { Desenvolvimento do Ensino Médio-técnico } \\
\text { Formação de Professores } \\
\text { Gestão da Política de Educação e cultura } \\
\text { Melhoria da Qualidade do Ensino } \\
\text { Merenda Escolar } \\
\text { Operação Carteira, Livro Escolar e Material Didático } \\
\text { Reabilitação da Infra-estruturas Institucionais } \\
\text { Reforma Educativa } \\
\text { Escola para Todos }\end{array}$ & $\begin{array}{r}8,52 \\
0,01 \\
0 \\
0 \\
0 \\
0,08 \\
8,1 \\
0,03 \\
0,07 \\
0,04 \\
0,02 \\
0 \\
0,16\end{array}$ \\
\hline
\end{tabular}

Fonte: Diário da República de Angola. İ. Série, nº. 103. 30 de dezembro de 2003, p. 459-2460. 
Segundo o Ministério da Educação, apesar do aumento contínuo do número de alunos (de 4.022.970 em 2004 para 4.879.811 em 2005), que têm procurado ingressar ao ensino escolar, os recursos destinados à educação neste ano de 2006 são inferiores, comparados aos dos anos de 2003 (6,24\%) e 2005 (10,47\%). Para o ano de 2006 os recursos, aprovados pelo Orçamento Geral do Estado em dezembro de 2005, para as despesas da educação são de 3,82\% e foram distribuídos da seguinte forma:

Tabela 20: Orçamento aprovado para as despesas da educação, 2006

\begin{tabular}{l|r}
\hline \multicolumn{1}{c|}{ Áreas de ensino / Programa } & rastos 2006 \\
Educação Pré-Escolar & $\mathbf{0}$ \\
Programa de reforma educativa & 0 \\
Ensino Primário & $\mathbf{1 , 3 9}$ \\
Prog. melh. e aumento da oferta de sist.sociais básicos às populações & 0,12 \\
Actividades permanentes & 0,92 \\
Subprograma de reabilitação e construção de escolas & 0,05 \\
Subprograma de apetrechamento de escolas & 0.02 \\
A determinar & 0,27 \\
Ensino Secundário & $\mathbf{0 , 7 2}$ \\
Prog.melh. e aumento da oferta de sist. sociais básicos às populações & 0,05 \\
Actividades permanentes & 0 \\
Subprograma de reabilitação e construção de escolas & 0,13 \\
Subprograma de apetrechamento das escolas & 0,02 \\
A determinar & 0,52 \\
Ensino de Adultos & 0 \\
Actividades permanentes & 0 \\
Ensino Técnico-Profissional & $\mathbf{1 , 1 6}$ \\
Prog. melh. e aumento da oferta de sist.sociais básicos às populações & 0,02 \\
Actividades permanentes & 0,45 \\
Programa de desenvolvimento do ensino técnico-profissional & 0,02 \\
Subprograma de capacitação dos recursos humanos & 0,02 \\
Subprograma de reabilitação e construção de escolas & 0,65 \\
Subprograma de apetrechamento das escolas & 0 \\
Ensino Superior & $\mathbf{0 , 3 8}$ \\
Prog. melh. e aumento da oferta de sist.sociais básicos às populações & 0,02 \\
Actividades permanentes & 0,27 \\
Subprograma de reabilitação e construção de escolas & 0,09 \\
Outros Serviços de Educação & $\mathbf{0 , 1 7}$ \\
Prog. melh. e aumento da oferta de sist.sociais básicos às populações & 0 \\
Actividades permanentes & 0,11 \\
Programa de reforma educativa & 0,05 \\
Programa de desenvolvimento do ensino técnico-profissional & 0 \\
Programa de implantação e desenv. do sistema de ensino especial & 0 \\
Suprograma de assistência social aos alunos na escola & 0 \\
\hline & 0
\end{tabular}

Fonte: Diário da República Angola. I Série, nº 156. 30 de dezembro de 2005, p. 3228. 


\section{3 - Definição e objetivos do novo sistema educacional}

A reforma educacional assenta-se na "Lei Constitucional, no plano nacional e nas experiências acumuladas e adquiridas a nível internacional" (LBSE - Lei de Bases do Sistema de Educação, Diário da República, Art.2 §1. 2001). Visa fundamentalmente, a escolarização das crianças, reduzir o analfabetismo de jovens e adultos e aumentar a eficácia educacional e, com isso, dar resposta às mudanças profundas que têm ocorrido no sistema socioeconômico angolano - de uma economia de orientação socialista para uma economia de mercado -, que de alguma forma exigem novos critérios organizacionais do sistema de educação e formação humana necessária, segundo a lei, ao "progresso sócio-econômico da sociedade angolana”. Entende-se por educação nesta nova lei o

\footnotetext{
processo que visa preparar o indivíduo para as exigências da vida política, econômica e social do país e que se desenvolve na convivência humana, no circulo familiar, nas relações de trabalho, nas instituições de ensino e de investigação científico-técnica, nos órgãos de comunicação social, nas organizações comunitárias, nas organizações filantrópicas e religiosas e através de manifestações culturais e gino-desportiva (LBSE $n^{\circ}$. 13/01. Diário da República, 2001).
}

Entende-se ainda por educação, conforme aponta o item dois do art. 1. da mesma lei, como o "conjunto de estruturas e modalidades, através das quais se realiza a educação, tendentes à formação harmoniosa e integral do indivíduo, com vistas à construção de uma sociedade democrática de paz e progresso social”.

Segundo o Art. 3 da mesma Lei $n^{0}$. 13/01, o novo sistema educacional tem como objetivos gerais:

a) Desenvolver harmoniosamente as capacidades físicas, intelectuais, morais, cívicas, estéticas e laborais da jovem geração, de maneira contínua e sistemática; elevar o seu nível científico e tecnológico a fim de contribuir para o desenvolvimento sócio-econômico de Angola; 
b) Formar indivíduos capazes de compreender os problemas nacionais, regionais e internacionais de forma crítica e construtiva para a sua participação ativa na vida social, à luz dos princípios democráticos;

c) Promover o desenvolvimento da consciência pessoal e social dos indivíduos em geral e da jovem geração em particular, o respeito pelos valores e símbolos nacionais, pela dignidade humana, pela tolerância e cultura de paz, pela unidade nacional, a preservação do ambiente e a conseqüente melhoria da qualidade de vida;

d) Fomentar o respeito aos outros indivíduos e aos superiores interesses da Nação Angolana na promoção do direito à vida, à liberdade e à integridade pessoal;

e) Desenvolver o espírito de solidariedade entre os povos, em atitude de respeito pela diferença de outrem, permitindo uma saudável integração no mundo.

De acordo com o Art. 4 do Capítulo 2 da mesma lei, o sistema educacional deve ser integral, isto é, ter correspondência entre os objetivos por ela traçados e as exigências de desenvolvimento de Angola. Sendo assim a materialização dos objetivos ligados diretamente à educação requerem do Sistema Educacional conteúdos e métodos de formação adequada para garantir a articulação permanente dos subsistemas, níveis e modalidades de ensino existentes no país.

Tal como no sistema anterior, aponta-se a laicidade e a independência de qualquer religião do sistema de educação. Elemento fundamental, não constante no anterior é, segundo o Art. 6, a questão democrática e o respeito às opções políticas e partidárias como aspecto fundamental para a unidade nacional e cultural. Entendendo-se com isso, a possibilidade de não haver qualquer distinção entre os cidadãos angolanos, uma vez que se trata de cidadãos portadores dos mesmos direitos de acesso e freqüência escolar e de participação na luta pela resolução dos problemas que Angola apresenta. 


\section{4 - Organização do novo Sistema de Ensino}

De acordo com a nova Lei de Bases do Sistema de Educação (LBSE) $n^{\circ} .13 / 01$ de 31 de dezembro de 2001, o sistema educacional atual estrutura-se em três níveis fundamentais: 1) Educação Pré-Escolar, 2) Ensino Geral, subdividido em Primário e Secundário, e 3) o Ensino Superior.

Diferente da estrutura educacional anterior, a nova apresenta um ano escolar a mais de ensino geral. E para o nível superior, que antes era somente o bacharelato e a licenciatura, encontra-se também estruturado o ensino de pós-graduação, com níveis de mestrado e doutorado. Mas, apesar de constar no cronograma do programa geral de ensino, o nível de mestrado e doutorado ainda não está em funcionamento no país em todos os cursos. Justifica-se esta ausência pela falta de infraestrutura e principalmente do corpo docente que se dedique à pesquisa e que tenha formação, competência e habilidade necessárias para o desenvolvimento da formação de candidatos ao mestrado e doutorado. A partir de 2003 começou o curso de PósGraduação (especialização e mestrado) na Universidade Agostinho, mas somente no curso de direito. Algumas universidades particulares oferecem também cursos de especialização profissional.

\subsection{Educação pré-escolar}

No novo Sistema Educacional a educação pré-escolar abarca a Creche e o Jardim de Infância e conta ainda com uma classe de iniciação de um ano de duração. E, de acordo com o Art. 11 da LBSE - Lei de Base do Sistema de Ensino -, o subsistema de "educação pré-escolar é a base da educação, cuidando da primeira infância, numa fase de vida em que se devem realizar as acções de condicionamento e de desenvolvimento psico-motor" (Ministério da Educação. LBSE, 2001, p. 6, vol. 4).

Quanto aos objetivos, a educação pré-escolar visa, de acordo com o Art. 12 da LBSE: 
a) Promover o desenvolvimento intelectual, físico, moral, estético e afectivo da criança, garantindo-lhe um estado sadio por forma a facilitar a sua entrada no subsistema de ensino geral;

b) Permitir uma melhor integração e participação de crianças através da observação e compreensão do meio natural, social e cultural que a rodeia;

c) Desenvolver as capacidades de expressão, de comunicação, de imaginação criadora e estimular a actividade lúdica da criança (Ministério da Educação. LBSE, 2001).

Em Angola, o número de crianças de dois a cinco anos fora do sistema de assistência à infância, programas de ensino infantil e iniciação ainda exige do Estado especial atenção, pois, de acordo com o Art. 11 da LBSE, a etapa de educação préescolar constitui aspecto fundamental, uma vez que esta serve de base para as demais etapas de crescimento e desenvolvimento da criança.

O Estado angolano comprometeu-se, no Fórum Mundial de Educação para Todos, realizado em Dakar (Senegal), em abril de 2000, com a política de expansão e melhoria dos cuidados, proteção e educação da primeira infância, sobretudo daquelas crianças que se encontram em situações vulneráveis e difíceis. Todavia, de 2000 até ao ano de 2006, ainda os compromissos de atendimento à infância assumidos neste Fórum, do qual Angola participou, carecem de uma ação política e intervenção mais efetivas do Estado angolano, para que as propostas de educação para todos até o ano de 2015 sejam minimamente asseguradas.

Os dois programas criados pelo MINARS (Ministério da Assistência e Reinserção Social) - o PIC (Programa Infantil Comunitário) e o PEC (Programa de Educação Comunitária) - também passam pelo problema de insuficiência de verbas e pessoal formado para que seus projetos possam realizar-se. O PIC destina-se à proteção e educação de crianças dos dois aos cinco anos. O PEC visa promover a formação comunitária, isto é, esclarecerem as famílias sobre os cuidados iniciais de crianças e incentivar estas famílias a colocarem seus filhos nas escolas.

Conforme consta do cronograma do programa de proteção especial das crianças em situação de risco, o PIC (Programa Infantil Comunitário), dirigido a crianças de dois a cincos, e o PEC (Programa de Educação Comunitária), dirigido à família e à comunidade, com a participação de adolescentes, mães, avos, etc., têm como principais objetivos: 
1. Expandir a cobertura de instituições que prestam cuidados e educação a crianças dos 0 aos 5 anos - PECs, Centros Infantis Públicos e Privados, Creches Comunitárias.

2. Reforçar os mecanismos de coordenação e articulação através de redes provinciais e municipais;

3. Promover serviços de qualidade para prevenir e reduzir a vulnerabilidade das crianças da $1^{\text {a }}$ infância 0-5 anos: assegurar o desenvolvimento da educação pré-escolar;

4. Assegurar alimentação e cuidados básicos de higiene e saúde

5. Assegurar programa educativo e aprendizagem da língua portuguesa

6. Desenvolver competências familiares

7. Contribuir para o aumento da renda familiar (MINARS, 2004).

Estes programas (PIC e PEC) carecem também de material pedagógico necessário à formação comunitária de agentes com formação pedagógica adequada para trabalhos comunitários, como para atuação no espaço de ensino infantil. Carecem de recursos financeiros e espaços físicos adequados ao trabalho de formação comunitária e ensino pré-escolar. Isso, em parte, limita o alargamento do trabalho destes programas, que têm atuado também na política de combate à subnutrição e pobreza.

\subsection{Ensino geral}

A formação geral que corresponde ao ensino primário e secundário constitui, segundo o Art. 14 da LBSE, o "fundamento do sistema de educação para conferir uma formação integral, harmoniosa e uma base sólida e necessária à continuação de estudos em subsistemas subseqüentes" (Ministério da Educação. LBSE, 2001).

De acordo com o Art. 15 da LBSE, constituem objetivos fundamentais e gerais deste subsistema de ensino geral:

1) Conceder a formação integral e homogênea que permita o desenvolvimento harmonioso das capacidades intelectuais, físicas, morais e cívicas;

2) Desenvolver os conhecimentos e as capacidades que favoreçam a auto-formação para um saber-fazer eficazes que se adaptem às novas exigências;

3) Educar a juventude e outras camadas sociais de forma a adquirirem hábitos e atitudes necessários ao desenvolvimento da consciência nacional; 
4) Promover na jovem geração e noutras camadas sociais o amor ao trabalho e potenciálas para uma actividade laboral socialmente útil e capaz de melhorar as suas condições de vida.

O subsistema de ensino geral é dividido em duas grandes etapas: o ensino primário, de $1^{\mathrm{a}}$. à $6^{\mathrm{a}}$. classe; o ensino secundário subdividido em dois ciclos. $\mathrm{O}$ primeiro ciclo com três anos de duração (da $7^{\mathrm{a}}$. à $9^{\mathrm{a}}$. classe) e o segundo, com três ou quatro anos (da 10a . à 12. ${ }^{\mathrm{a}}$ ou $13^{\mathrm{a}}$. classe), de duração variável, dependendo da modalidade ${ }^{58}$ que o estudante escolher depois que terminar o primeiro ciclo.

\section{a) Ensino primário}

Este nível de ensino, diferente do antigo, que ia da primeira à quarta classe, comporta, no atual sistema, seis anos de estudos, isto é, da primeira à sexta classe e continua sendo o único nível obrigatório, de acordo com o Art. 8 da LBSE (2001) e gratuito, segundo o Art. 7. A gratuidade apontada pelo Art. 7 da LBSE consiste na "isenção de qualquer pagamento pela inscrição, assistência às aulas e o material escolar", e isto é válido tanto para o ensino geral como para o subsistema de educação de adultos.

Ainda de acordo com o parágrafo terceiro do Art. 7 da LBSE (2001), o "pagamento da inscrição, da assistência às aulas, do material escolar e do apoio social nos restantes níveis de ensino, constituem encargos para os alunos”. Estes podem recorrer "se reunirem as condições exigidas, à bolsa de estudo interna, cuja criação e regime devem ser regulados por diploma próprio".

De acordo com o Art. 18 da LBSE (2001), apontam-se os seguintes objetivos específicos deste nível de ensino primário:

a) Desenvolver e aperfeiçoar o domínio da comunicação e da expressão;

b) Aperfeiçoar hábitos e atitudes tendentes à socialização;

c) Proporcionar conhecimentos e capacidades de desenvolvimento das faculdades mentais;

d) Estimular o espírito com vista ao desenvolvimento da criação artística;

\footnotetext{
${ }^{58} \mathrm{O}$ aluno que termina o primeiro ciclo $\left(9^{\mathrm{a}}\right.$. classe) tem a possibilidade de escolher, entre os vários cursos médios (de Medicina, Ciências Sociais, Enfermagem, Economia, etc.) existentes, o curso que melhor lhe convém estudar (ou ainda aquele em que conseguir uma vaga).
} 
e) Garantir a prática sistemática de educação física e de actividades gimno-desportivas para o aperfeiçoamento das habilidades psicomotoras.

Este nível de ensino constitui, segundo a LBSE, a base do ensino geral, tanto para a educação regular como para educação de adultos e é tido como ponto de partida para os demais níveis de ensino.

\section{b) Ensino secundário}

O Ensino Secundário está estruturado em dois ciclos. O primeiro ciclo do ensino secundário tem a duração de três anos e começa na sétima classe e termina na nona classe.

Segundo a LBSE (2001) Art. 20, os objetivos específicos do primeiro ciclo são:

1) Consolidar, aprofundar e ampliar os caminhos e reforçar as capacidades, os hábitos, as atitudes e as habilidades adquiridas no ensino primário;

2) Permitir a aquisição de conhecimentos necessários ao prosseguimento dos estudos em níveis de ensino e áreas subseqüentes.

O segundo ciclo do ensino secundário está organizado em três linhas: Ensino Médio Técnico, que começa na $10^{\mathrm{a}}$. classe e termina na $13^{\mathrm{a}}$. classe; o Ensino Médio Normal, que também começa na $10^{\mathrm{a}}$. classe e termina na $13^{\mathrm{a}}$. classe; e o Ensino Médio Geral de três anos de duração, que começa na $10^{\mathrm{a}}$. classe e termina com a $12^{\mathrm{a}}$. classe.

E ainda de acordo com o parágrafo dois do Art. 20, os objetivos específicos do segundo ciclo de ensino secundário são:

1) Preparar o aluno para ingresso no mercado de trabalho e/ou no subsistema de ensino superior;

2) Desenvolver o pensamento lógico e abstrato e a capacidade de avaliar a aplicação de modelos científicos na resolução de problemas da vida prática.

O segundo ciclo de ensino conta também com uma formação intermediária de um ou dois anos para a profissionalização daqueles que concluíram a 
$12^{\mathrm{a}}$. classe do Ensino Médio Geral e não conseguiram ou não querem ingressar no Ensino Superior. E para aqueles que fazem o Ensino Médio Normal ou Técnico esta formação intermediária de profissionalização de um ou dois anos começa depois que se conclui a $12^{\mathrm{a}}$ classe do segundo ciclo do ensino secundário geral regular ou da educação de adultos.

O ensino técnico profissional visa, segundo o Art. 22 da LBSE (2001), a "formação técnica e profissional dos jovens em idade escolar, candidatos a emprego e trabalhadores, preparando-os para o exercício de uma profissão ou especialidade, por forma a responder às necessidades do país e à evolução tecnológica”. Este subsistema de ensino técnico profissional está estruturado em formação básica e formação técnica.

Segundo o Art. 24 da LBSE, a formação básica é tida como o ponto principal e inicial para que se possa continuar com a formação técnica e, sendo assim, de acordo com este artigo:

1) A formação profissional básica é o processo através do qual os jovens e adultos adquirem e desenvolvem conhecimentos gerais e técnicas, atitudes e práticas relacionadas directamente com o exercício duma profissão.

2) A formação profissional básica visa a melhor integração do indivíduo na vida activa, podendo contemplar vários níveis e desenvolver-se por diferentes modalidades e eventualmente contemplar a formação escolar no quadro da educação permanente.

3) A formação profissional básica realiza-se após a $6^{\mathrm{a}}$. classe nos centros de formação profissional públicos e privados.

4) A formação profissional básica rege-se por diploma próprio.

Por outro lado, a formação profissional, que começa com a $10^{\mathrm{a}}$. classe, é concebida, segundo o parágrafo primeiro do Art. 25 da LBSE (2001), como uma etapa fundamental para a inserção às atividades práticas de trabalho. Esta formação técnicoprofissional dos jovens e trabalhadores "visa proporcionar aos alunos conhecimentos gerais e técnicos para os diferentes ramos de actividade econômica e social do país, permintindo-lhes a inserção na vida laboral e mediante critérios, o acesso ao ensino superior". 


\subsection{Educação de adultos}

O subsistema de educação de adultos estrutura-se também em ensino primário, que corresponde à alfabetização e pós-alfabetização, e na seqüência, em ensino secundário, que compreende os dois ciclos. Diferente do ensino geral normal, o ensino de adultos tem uma organização programática de conteúdos mais voltados ao mundo adulto. Desta forma as metodologias de educação e avaliação aplicadas a este sistema de educação também são diferenciadas e adequadas às características, necessidades e aspirações dos adultos.

Segundo o Art. 32 da LBSE (2001), os objetivos da educação de adultos consistem em:

a) Aumentar o nível de conhecimentos gerais mediante a eliminação do analfabetismo juvenil e de adulto, literal e funcional;

b) Permitir a cada indivíduo aumentar os seus conhecimentos e desenvolver as suas potencialidades, na dupla perspectiva de desenvolvimento integral do homem e da sua participação activa no desenvolvimento social, econômico e cultural, desenvolvendo a capacidade para o trabalho através de uma preparação adequada às exigências da vida activa;

c) Assegurar o acesso da população adulta à educação, possibilitando-lhes a aquisição de competências técnico-profissionais para o crescimento econômico e o progresso social do meio que a rodeia, reduzindo as disparidades existentes em matéria de educação entre a população rural e a urbana numa perspectiva do gênero;

d) Contribuir para a preservação e desenvolvimento da cultura nacional, a protecção ambiental, a consolidação da paz, a reconciliação nacional, a educação cívica e cultural, o espírito de tolerância e respeito pelas liberdades fundamentais;

e) Transformar a educação de adultos num pólo de atracção e de desenvolvimento comunitário e rural integrados, como factor de actividade sócio-económica e para a actividade do indivíduo.

Não muito diferente das dificuldades que o ensino de adultos enfrentava no momento da guerra, no atual momento, as principais dificuldades que neste sistema de ensino de adultos se constatam consistem na ausência de espaços físicos adequados a este tipo de ensino. E, tal como em outros níveis de ensino, este também carece de investimentos e de uma administração pedagógica mais eficiente. 


\subsection{Ensino especial}

O ensino especial, tanto no sistema de ensino geral como no sistema de ensino de adultos, é destinado àqueles que apresentam necessidades educativas especiais, como deficiência motora, sensorial, mental ou transtornos de conduta. Ele visa ainda tratar de recuperar e permitir a integração sócio-cultural educativa e econômica de pessoas que se encontram nestas condições especiais.

Segundo o Art. 44 da LBSE (2001), constituem objetivos principais da educação especial:

a) Desenvolver as potencialidades físicas e intelectuais reduzindo as limitações provocadas pelas deficiências;

b) Apoiar a inserção familiar, escolar e social de crianças e jovens deficientes ajudandoos na aquisição de estabilidade emocional;

c) Desenvolver as possibilidades de comunicação;

d) Desenvolver a autonomia de comportamento a todos os níveis em que esta se possa processar;

e) Proporcionar uma adequada formação pré-profissional e profissional visando a integração na vida activa;

f) Criar condições para o atendimento dos alunos superdotados.

De acordo com o Art. 45 da LBSE (2001), a educação especial deverá ser ministrada em instituições de "ensino geral, da educação de adultos ou em instituições específicas de outros sectores da vida nacional cabendo, neste último caso, ao Ministério da Educação e Cultura a orientação pedagógica, andragógica ${ }^{59}$ e metodológica" das atividades educativas.

\subsection{Ensino superior}

O ensino superior está estruturado em graduação e pós-graduação. E a graduação por sua vez subdivide-se em bacharelato e licenciatura. $\mathrm{O}$ bacharelato visa

\footnotetext{
${ }^{59}$ Atividades educativas ou de ensino voltadas para os adultos.
} 
permitir, segundo o parágrafo dois do Art. 38 da LBSE (2001), “ao estudante a aquisição de conhecimentos científicos para o exercício de uma actividade prática no domínio profissional respectivo, em área a determinar, com carácter terminal”. O curso de bacharelato corresponde a ciclos curtos, com a duração de três anos.

A licenciatura corresponde a uma formação mais alargada de quatro a seis anos de duração, dependendo do curso e, ainda de acordo com o artigo acima, parágrafo terceiro, a licenciatura tem como objetivo a "aquisição de conhecimentos, habilidades e práticas fundamentais dentro do ramo do conhecimento respectivo e a subseqüente formação profissional ou acadêmica específica” (Art. 38 da LBSE, 2001).

A pós-graduação está estruturada em mestrado acadêmico de dois a três anos de duração. Este visa essencialmente enriquecer e desenvolver competências técnico-profissionais do indivíduo licenciado. A pós-graduação profissional, que compreende a especialização de um ano de duração, visa proporcionar a formação e o aperfeiçoamento técnico-profissionais do licenciado.

O doutoramento, de quatro a cinco anos de duração, tem por objetivo proporcionar, segundo o parágrafo sexto do Art. 39 da LBSE (2001), a "formação científica, tecnológica ou humanista, ampla e profunda aos candidatos diplomados em cursos de licenciatura e/ou mestrado".

\section{5 - Etapas e critérios de implementação da reforma educacional}

Como já foi mencionado, o primeiro diagnóstico do sistema educacional angolano foi realizado em 1986, nos meses de março e junho, e a partir daí verificou-se que vários aspectos do sistema educacional implementado em 1978 careciam de reformas. A partir desta data concebeu-se então a necessidade de se pensar em novas perspectivas de organizar o sistema educacional, o que resultou, em 2001, na aprovação da nova lei $\mathrm{n}^{0}$. 13/01, que regulamenta o novo sistema educacional e suas reformas.

Diferente da primeira reforma, a implementação da atual reforma, segundo o Ministério da Educação, obedece a cinco etapas ou fases, podendo uma coexistir com a outra. A primeira fase, chamada de preparação, começou em 2002 e irá até 2012. A segunda fase, chamada de experimentação, começou dois anos mais tarde 
que a de experimentação, isto é, em 2004 e irá até 2010. A terceira fase, chamada de avaliação e correção, começou em 2004 e irá até 2010. A quarta fase, chamada de generalização, começou em 2006 e terminará em 2011. Finalmente a quinta e última fase, que é da avaliação global, começará em 2012 e terminará em 2015.

\section{a) Fase de preparação - $2002 / 2012$}

A fase de preparação para a implementação do novo sistema educacional consiste na preparação de condições que possam assegurar o funcionamento adequado dos pressupostos delineados. Segundo o Ministério da Educação, nesta fase, as principais atividades que se pretendem realizar visam a adequação do sistema de administração e gestão do ensino, organização e elaboração de novos currículos - "perfis de saída, planos de estudos, programas de ensino e materiais pedagógicos" (Ministério da Educação, 2001, p. 28, vol. 6).

Pretende-se também, nesta fase, efetuar a reprodução e distribuição dos novos currículos, além da formação de "pessoal docente e de gestores escolares, a aquisição e dotação das instituições escolares de meios de ensino e equipamentos e ainda a reabilitação e construção de infra-estruturas escolares" (Ministério da Educação, 2001, p. 28, vol. 6).

\section{b) Fase de experimentação - $2004 / 2010$}

A partir de 2004 começou a implementação da segunda fase de experimentação do novo Sistema Educacional, que consiste, segundo o Ministério da Educação, na aplicação, a título experimental, dos currículos produzidos. Nesta fase, segundo o Ministério da Educação, poderão ser contempladas somente algumas “instituições escolares em cada uma das 18 províncias do país, a fim de possibilitar que em cada uma delas, se desenvolvam experiências e competências próprias e locais de gestão da implementação do Novo Sistema de Educação" (Ministério da Educação, 2001, p. 28). A implementação desta fase é progressiva e está sendo feita em diferentes classes desde 2004 e pretende concluir-se em 2010. 


\section{c) Fase de avaliação e correção - 2004 /2010}

A implementação da terceira fase do novo sistema educacional consiste, segundo o Ministério da Educação, na "experimentação e correção, com base nos dados recolhidos durante a fase de experimentação do Novo Sistema de Educação, essencialmente na adequação dos currículos" (Ministério da Educação, 2001, p. 29, vol. 6). Esta fase começou e terminará no mesmo ano da fase da experimentação.

Para todos os níveis, a extinção progressiva anual deve-se, segundo o Ministério da Educação (2001, p. 31, vol. 6), à "escassez de recursos financeiros para a execução das inúmeras actividades que a implementação do Novo Sistema de Educação requer". As atividades principais apontadas visam atender, segundo o Ministério da Educação (2001, p.31, vol. 6) a “elaboração, edição, aquisição e distribuição de manuais e livros escolares, de equipamentos e de mobiliário escolar, a reabilitação de infraestruturas escolares, a capacitação de professores" na utilização dos novos programas e dos materiais pedagógicos e a capacitação dos gestores escolares.

\section{d) Fase de generalização - $2006 / 2011$}

A quarta fase, que corresponde à etapa da generalização do novo Sistema Educacional e aplicação dos seus respectivos currículos em todo o país, começou em 2006 e terminará em 2011. E, tal como outras fases, esta será também aplicada progressivamente, isto é, em uma classe após outra, a cada ano. À medida que se estiver implementando o novo sistema de ensino, ir-se-á extinguir também o sistema de ensino anterior.

\section{e) Fase de avaliação global - 2012 /2015}

A última fase consiste na avaliação global do Sistema Educacional implementado. Segundo o Ministério da Educação (2003), a "globalidade será assegurada com a abrangência da avaliação dos principais dispositivos do Sistema de Educação". A avaliação poderá consistir na análise dos currículos, processo de ensino e aprendizagem, corpo docente e discente, administração e gestão dos recursos materiais.

Conforme consta do relatório da reforma e implementação do novo Sistema Educacional, esta etapa poderá realizar-se a partir de 2012, depois que todo o sistema estiver em funcionamento regular. 


\section{CAPÍtulo V}

\section{DESENVOLVIMENTO POLÍTICO-ECONÔMICO E A GARANTIA DO DIREITO À EDUCAÇÃO}

O contexto político social que Angola apresenta desde 2002 obriganos a uma reflexão filosófica mais atenta do papel da educação na sociedade e, mais concretamente, da universidade $^{60}$ (ensino e pesquisa). Nesta reflexão há que incluirmos as questões atinentes aos aspectos financeiros da educação, ao crescimento e desenvolvimento econômico, à democracia e garantia do direito à educação enquanto aspectos fundamentais para a "melhoria" das condições de vida social. O tema é desafiador e de vital importância. Todavia, são escassos os espaços que poderiam propiciar uma discussão ampla de crítica e análise política destas questões no país. E, tanto no espaço escolar como nos meios de comunicação social e político, ainda é notória a falta de garantia do direito à liberdade de expressão.

Abordar a implementação do direito à educação é fundamental para a sociedade angolana, sobretudo, neste momento em que a política econômica do desenvolvimento do capital se realiza através da entrada de capitais e investimentos externos, impulsionados e justificados, em grande parte, pelo discurso de desenvolvimento e crescimento econômico sustentável. Cabe destacar que este discurso de desenvolvimento do capital econômico requer, também, uma análise exaustiva, pois ele pode camuflar o problema da violência constante contra a dignidade humana, na

\footnotetext{
${ }^{60} \mathrm{O}$ ensino superior em Angola começou em 1962, quando Portugal determinou a construção de instituições de ensino superior em suas colônias da África. Desta data até finais da década de 90, em Angola, existiu uma única Universidade (Universidade Agostinho Neto). Além de a rentabilidade ser muito baixa (menos de $25 \%$ concluem o curso), durante estes anos, o que mais se efetivou foi o ensino, sem a pesquisa e extensão universitária. Segundo Kajibanga, (2000, p. 129) os principais problemas que se encontram na base da ineficácia pode ser: a "exigüidade do corpo docente e a falta de qualificação pedagógica dos mesmos; os magros e selváticos salários pagos ao corpo docente". Kajibanga aponta também a "rigidez e esquematização dos programas curriculares e conteúdos programáticos, os parcos recursos financeiros afectados ao ensino superior e a ausência de políticas públicas consentâneas para o desenvolvimento do ensino superior em Angola”. De forma geral, apontam-se também a falta de liberdade intelectual e a submissão do corpo docente ao sistema político implantado como fatores que contribuíram para o não desenvolvimento do ensino superior de Angola.
} 
medida em que o crescimento e desenvolvimento do capital econômico não reflete diretamente o desenvolvimento social.

Quando falamos em falta de responsabilidade, neste capítulo, entendemos com isso o sistema que inviabiliza a efetivação de uma política pública concreta e eficaz de desenvolvimento social, de garantia do direito à educação, trabalho, saúde, etc., como também, a falta de estratégia e responsabilidade política no uso e administração dos bens públicos.

Entendemos que o papel que a educação desempenhou nestes últimos dez anos, no sistema de produção, reprodução e manutenção do discurso de crescimento do capital econômico, requer ser revisto, uma vez que a superação dos problemas que o país atravessa obriga-nos a ver a educação não apenas como instrumento de manutenção e legitimação da ordem vigente, limitada à formação da mão de obra - capital humano -, mas sim, a partir da relação política, filosófica, ética, e tecnológica, vendo o bem-estar do homem como o fim último da preocupação político-educacional.

\section{1 - Depois do "socialismo": o papel da educação na produção e reprodução do sistema capitalista}

Conforme abordamos no primeiro capítulo, a política que vigorou em Angola desde a independência foi a do partido único, sob o governo do MPLA, (19751990), baseado, segundo o discurso divulgado, na ideologia do socialismo (marxismoleninismo). A partir de 1990 mudou-se a política de partido único para dar espaço ao multipartidarismo - resultado das negociações entre o MPLA e a UNITA para terminar a guerra civil até então em vigor em Angola -, o que permitiu a realização das primeiras eleições presidências e legislativas em Angola. Depois das eleições, em setembro de 1992, o governo no poder (MPLA) adotou a política de economia de mercado (capitalismo).

Nossa preocupação, nesta abordagem, é com a educação, pois, diferente dos ideais de educação do socialismo (que defende "as necessidades ou ideais da maioria"), as relações e objetivos da educação no sistema de produção e reprodução capitalista (sob a base de economia de mercado) e os pressupostos filosóficos e políticos 
de formação visam, acima de tudo, preparar a mão de obra "qualificada", que permita ao capitalista a obtenção de maiores lucros possíveis. Enquanto que no socialismo o foco estava voltado para a vitória e "bem-estar" da população como um todo, no capitalismo o foco do sucesso passou a ser o indivíduo, que busca para si a vitória e seu bem-estar. O ensino é importante na medida em que é necessária a manutenção da força de trabalho especializada.

Contudo, sabe-se que a educação, mesmo parecendo não representar aspecto fundamental na visão de alguns políticos mais preocupados com o treinamento profissional ao invés da educação como formação do ser humano, para o sistema capitalista seguir seu rumo de funcionamento, em meio a mudanças e contradições, notamos que a educação continua desempenhando um papel fundamental na manutenção de um sistema político, pois, por meio dela, tem se formado a nova força de trabalho "qualificada" para dar continuidade ao processo de produção.

À educação coube a tarefa de, continuamente, inventar e reinventar novos propósitos de acordo com as necessidades produtivas e a manutenção do novo sistema político. Como vemos, no caso de Angola, por constituir um elemento primordial na manutenção da ordem e legitimação do discurso de crescimento e desenvolvimento, a educação mais uma vez se adequou às transformações políticas dessa sociedade: de uma política autoritária (partido único) para a política multipartidária (democracia).

No sistema capitalista, as condições gerais de produção requeridas vão desde a educação escolar e familiar à manutenção da ordem ou do meio social. Por exemplo, segundo Bernardo, enquanto na empresa o trabalho realizado destina-se à produção de bens ou de serviços, por outro, o trabalho doméstico destina-se exclusivamente a colaborar em duas operações:

a reconstituição da força de trabalho assalariada e a produção de uma nova força de trabalho. Quer dizer, o trabalho doméstico incide na reprodução alargada da força de trabalho proletária de geração para geração, mediante a conservação da força de trabalho existente já produzida e a criação e educação de filhas e filhos, que irão ser a nova força de trabalho (Bernardo, 1985 , p. 87). 
$\mathrm{Na}$ perspectiva do sistema de economia de mercado, adotado em Angola, a aula não é outra coisa, senão o processo de trabalho do professor, e a qualificação que lhe é exigida, o seu produto. Ao capitalista interessa a qualificação do professor, isto é a capacidade de trabalho, importante para a produção e reprodução. Desta forma a escola não só é produtora - da qualificação /capacidade de trabalho como também é produto. Esta situação permite mantê-la num ciclo em que, continuamente, ela procura criar novos propósitos e objetivos para a sociedade.

É importante notar que a educação do futuro trabalhador não é estática. Ela muda constantemente em função das novas relações, construídas no sistema de produção, e da complexidade destas relações, que exigem um trabalhador intelectualmente mais apurado. Uma das situações que leva à educação diferenciada, entre os trabalhadores diz respeito às condições (capital econômico) fornecidas desde a família (dependendo da classe à qual o trabalhador pertence), que permitem ascender mais ou menos aos vários níveis de classes no sistema capitalista e à aquisição das habilidades exigidas pelo mercado de trabalho. Desempenha papel importante o capital econômico familiar, no momento da decisão ou da escolha, por exemplo, do tipo de formação que o novo trabalhador deverá receber e a posição que este ocupará na produção e reprodução do sistema capitalista.

Partindo destas diferenças que se estabelecem desde a família, não temos como afirmar categoricamente que todo trabalhador, a partir do momento que recebe a educação, estará qualificado e conseqüentemente desenvolvido social e economicamente, pois esta relação não é linear. Como afirma Lúcia Bruno (1996)

\footnotetext{
a relação existente entre educação, qualificação e desenvolvimento econômico não é de nenhuma forma linear, e para compreendê-la em sua dinâmica, hoje, é necessário considerar não apenas os diferentes padrões de acumulação de capital que presidem o desenvolvimento econômico de diferentes países e regiões, mas também as transformações sem precedentes pelas quais vêem passando o capitalismo desde a década de 70 (Bruno, 1996, p. 91).
}

E quando se trata do consumo, vale lembrar que este também não se dá da mesma forma para o possuidor do capital e para o trabalhador que possui apenas a força física. E mesmo quando se trata do significado do consumo, também se nota uma 
grande diferença. Como dizia Bernardo (1985, p. 88), "existe uma radical distinção, quanto aos mecanismos e ao significado econômico, entre o consumo de bens pelo proletariado e pelas classes capitalistas; a produção e reprodução física dos capitalistas é um processo interno ao consumo improdutivo". O consumo respeita à utilização do lucro e não a produção de mais-valia. Neste sentido é inviável, afirma Bernardo, "pensar o consumo como uma categoria econômica própria e autônoma".

A compreensão dos rumos da educação torna-se ainda mais complexa quando os trabalhadores são postos diante da nova pressão político-econômica da globalização que, necessariamente, leva a educação a repensar seus objetivos em cada sociedade para o século XXI. Com isso, em relação à educação, entendemos que é preciso procurar compreender os aspectos principais que fundamentam sua razão de ser, ante a pressão política da globalização, que a obriga a assumir novos objetivos para a formação da classe trabalhadora - força de trabalho qualificado - mas que, no final, diminui o valor desse trabalho, permitindo a obtenção do maior lucro possível por parte do capitalista. É importante também notar que, mesmo quando determinadas carências, como a educação do trabalhador e de seu filho, são suprimidas pela oferta da educação sem necessidades de pagamento por parte deste trabalhador, a "ausência de pagamento não significa gratuidade" (Bernardo, 1985, p. 89), isto porque existem impostos, pagos pelos trabalhadores, justificados pelo discurso de melhoria de ensino, construção de escolas, saúde, etc.

O aumento permanente da instrução ${ }^{61}$, que nestes últimos cinco anos tem sido defendido em Angola, é importante ao sistema de produção capitalista, justamente porque, alargando-se a difusão dos conhecimentos, requeridos se barateia, por outro lado, o valor deste conhecimento e, desta forma, se obtém uma força de trabalho relativamente mais favorável ao capitalista. E com o surgimento de instituições de ensino superior particulares nota-se que a maior parte da formação, aos poucos, está sendo ministrada não a partir da "generosidade dos proletários da geração precedente, que não possuem os novos conhecimentos e especialidades requeridos" (Bernardo,

\footnotetext{
${ }^{61} \mathrm{O}$ aumento permanente da instrução interessa ao capitalista como também aos trabalhadores. Todavia, vale lembrar que o interesse não é exatamente o mesmo, uma vez que para um significa maior produtividade e portanto melhores lucros e para o outro uma forma de manter-se empregado, o que não lhe tira da condição de não possuidor dos meios de produção.
} 
1985, p. 92), mas por “empresas" especializadas na formação ${ }^{62}$ da mão de obra requerida pelo mercado de trabalho angolano.

Em função disso tem-se verificado também em Angola um "permanente acréscimo da importância relativa das empresas de serviços especializados em aspectos específicos dessa formação escolar - o que é mais um fator que reforça o papel do Estado" (Bernardo, 1985, p. 92). O aumento relativo não significa que o trabalho doméstico (braçal) perderá sua importância na formação das novas gerações de trabalhadores, pois, ao incorporar sempre uma parte relativa maior do trabalho especializado permite que continue mantendo o ciclo do processo produtivo. Desta forma, o sistema capitalista "produz gerações proletárias capazes de proceder a um trabalho sempre mais complexo" (Bernardo, 1985, p. 92) e, a partir do momento em que as novas gerações de trabalhadores, com a "capacidade acumulada para proceder a um trabalho mais complexo, começam a realizar na prática, em proveito do capitalista, o valor de uso da força de trabalho", (Bernardo, 1985, p. 93) constata-se por um lado, que o capitalista, ao mesmo tempo em que se apropria dos frutos desse valor acrescido, também desvaloriza por outro lado, essa força de trabalho.

Dois dos mecanismos ultimamente usados para a desvalorização da força de trabalho têm sido a inflação, que permite a desvalorização acelerada da força de trabalho, e o "desemprego planejado", que ao fazer com que uma grande parcela da população esteja fora do mercado de trabalho, permite maior disputa pelas poucas vagas de trabalho disponíveis e, conseqüentemente, diminuir o salário do trabalhador. O desemprego

reduzido a reconstituição da força de trabalho ao mínimo físico socialmente admitido e eliminando a reconstituição das suas capacidades técnicas, é uma forma bruta e maciça de proceder à desvalorização da força de trabalho, pela sua própria desqualificação (Bernardo, 1985, p. 96).

O discurso de crescimento e desenvolvimento econômico sustentável, que ultimamente tem sido defendido pelo Estado angolano em seu sistema de governo, requer assim, ser estudado visando a compreensão dos mecanismos sobre os quais se

${ }^{62}$ Não deixamos de incluir aquelas faculdades (instituições) preocupadas mais com o rendimento econômico da instituição do que com o rendimento educacional (formação) propriamente dito das pessoas que nela encontram-se matriculadas. 
sustenta, e por outro, a percepção do seu poder e a forma de exercê-lo, pois, enquanto permanecerem os mesmos mecanismos administrativos de economia e de controle do poder será difícil, para os trabalhadores, efetuarem uma ofensiva (empreender uma luta por direitos trabalhistas), visando a melhoria de condições de trabalho.

Entendemos que a superação do homem produto e produtor da mercadoria e, portanto, também mercadoria, no sistema de produção capitalista, exige que a educação ${ }^{63}$ recupere o ideário de formação do homem integral. Implica em inventar e reinventar novos pressupostos de uma revolução cultural sem barbáries (guerra), remetendo o próprio sistema capitalista a uma transformação, visando ao bemestar da sociedade angolana.

A preocupação com o redimensionamento do discurso visa, essencialmente, atender à necessidade de compreender as trajetórias internas e externas do poder, que tanto influencia nossas mentes (nossas práticas, posicionamento) e que, às vezes, nos impossibilita de pensar fora do sistema político institucionalizado e das "verdades feitas" de interesses de poucos em detrimento de muitos. Estamos de acordo com a idéia, segundo a qual, a educação deve favorecer o entendimento das questões socioeconômicas e históricas de Angola, da democracia enquanto forma política, que permite maior participação social e manifestação de liberdade, da paz, entendida aqui não apenas como ausência da guerra, mas também como reconhecimento da diversidade (complexidade) cultural da qual é formada Angola, e da justiça enquanto mecanismo jurídico que permite a todos a garantia dos direitos fundamentais e seus respectivos deveres (Estado e sociedade), pois ensinar ciência sem consciência pode levar à destruição do homem pelo homem.

Em várias sociedades do século XIX, entendia-se que o ideário da educação deveria consistir na busca pela razão, isto é, a "recuperação da experiência sensível [...] e a confiança no poder transformador do homem [...] uma escola capacitada para disseminar os conhecimentos acumulados e as luzes da razão: uma escola pública, obrigatória, universal e laica" (Gamboa, 2001, p. 80). Com a repartição

\footnotetext{
${ }^{63}$ A educação, segundo Gamboa, 2001, p. 101; "deve articular as dimensões do intelecto, a consciência e a vontade, ou o saber, a ética e a virtude para fazer do homem um ser "humano", no sentido de que "o homem tem necessidade de ser formado para se tornar homem" e não apenas máquina produtiva. Essa tríade conceitual exige a construção de práticas educativas que desenvolvam a relação entre conhecimentos científicos e filosóficos, acumulados pela humanidade, a formação ética de cidadãos solidários e o compromisso político com as lutas de superação das formas de exploração do homem pelo homem".
} 
das atividades de produção, a educação para todos se diferenciou, e as relações tornaram-se mais complexas. Enquanto, por um lado, se generalizou uma educação para todas as camadas da população, voltada ao trabalho, por outro, se restringiu à classe que comanda o processo de produção uma educação política e filosófica mais abrangente.

Ao alcançar esta forma de diferenciação - da educação estruturada mediante as classes -, a escola transformou-se não só num elemento de socialização, mas também de discriminação, uma vez que a uns é destinada uma educação com mais exigência e qualidade de pensamento e de relações políticas da sociedade e a outros, uma educação "limitada", simplesmente, ao saber ler e escrever para dar conta do trabalho e das informações que este deve decifrar no trabalho, em outras palavras, pode se dizer que à população em geral oferece-se uma formação mais voltada ao mercado, isto é, à constituição de uma força de trabalho qualificado.

A manutenção do discurso de desenvolvimento do capital exige que se aponte a qualificação do indivíduo como fator principal no crescimento da economia. Entretanto, este discurso apresenta contradições, uma vez que a qualificação que se busca não alcança a maioria da população, mesmo porque, com o surgimento de aparelhos altamente qualificados, o número de profissionais exigido é cada vez menor, comparado ao número daqueles que se formam anualmente nas faculdades. As crises econômicas e políticas, que várias sociedades enfrentam, têm sido apontadas como pontos originários da falta de qualidade no ensino, mesmo que estas crises não tenham uma relação direta com o trabalho do professor em sala de aula.

É certo que, sem recursos econômicos nem políticas públicas de desenvolvimento social sustentável, a superação do analfabetismo permanece inatingível. No entanto, mesmo quando se pensa nos países desenvolvidos, que investem mais em educação, é possível notar outro "problema": o analfabetismo funcional. Como afirma Gamboa (2001, p. 84), “apesar dos investimentos no setor educacional terem se expandido, o analfabetismo funcional continua sendo um grave problema para o país hegemônico do primeiro mundo". Isso leva-nos a pensar que qualquer medida política que vise acabar com o analfabetismo requer ter em conta, não só o saber ler, como também do não se limitar apenas ao saber ler, pois este é apenas um dos passos necessários para levar o indivíduo a ingressar no mundo da compreensão das questões fundamentais da sociedade e do desenvolvimento do próprio saber. 
É nas condições sociais concretas que podemos encontrar possibilidades de acontecimentos ou transformações e, desta forma, indagarmo-nos a respeito do futuro da educação e suas possibilidades de mudanças. A responsabilidade política é necessária para garantir ao cidadão o direito fundamental (educação, saúde e trabalho) à vida pública. A inversão do ideário de formação do homem integral para a do homem trabalhador altera os propósitos da educação, pois, sob a ótica fabril, segundo Gamboa (2001, p. 85), os "métodos pedagógicos têm a pretensão de objetivos neutros e científicos, buscando a eficiência instrumental, sendo que a didática se reduz à operacionalização de objetivos de instrução", o que leva a mecanização dos processos de ensino e da aprendizagem. É dada à escola a tarefa de produzir, tal como as empresas, a mercadoria chamada "capital humano".

A disputa da educação - propósitos e objetivos - se dá no jogo de poder político feito de interesses de grupos ou classes. Isso não pode levar a desvinculála da subjetividade humana, uma vez que o homem necessita da educação para tornar-se homem, sem restringi-lo a uma concepção de máquina produtiva. A educação pode estabelecer uma relação entre ciência - tecnologia produzida - e ética, política e filosofia, não permitindo uma separação entre a "objetividade dos processos técnicos" e os valores da subjetividade na dinâmica social, política, cultural e ideológica de cada sociedade, pois, como afirma Gamboa (2001, p. 86), "nenhum processo didático pode ser entendido apenas como aplicação de técnicas ou metodologias, ao contrário, só tem sentido na articulação com as concepções da educação, da sociedade, da cultura e da política".

A partir da desarticulação dos princípios fundamentais da educação do homem "integral" e da continuidade da relação de classes (proprietários e trabalhadores), permite-se que a acumulação do capital permaneça na mão de poucos, e as revoluções que se tentam fazer não se completam, na sua totalidade, em função da permanência de divisões e desigualdades cada vez mais acentuadas nas questões econômicas e políticas. A educação ao seguir este rumo do discurso de desenvolvimento ou crescimento econômico, que não significa necessariamente desenvolvimento social, legitima o discurso segundo o qual a formação da classe trabalhadora (força de trabalho) não precisa vincular-se à compreensão da sociedade e da política, mas sim, ao saber fazer. 
Devido à produção de produtos de consumo, como eletrodomésticos, que requerem do consumidor um mínimo de conhecimento da escrita, importa ao sistema capitalista que se expanda um tipo de educação (popular), pois interessa ao dono do capital que o seu consumidor seja alfabetizado para estar à altura de decodificar a linguagem do seu produto e para que, com isso, possa estimulá-lo melhor ao consumo. Portanto, o objetivo desta educação não é levar a uma qualificação "altamente profissional", mas sim, permitir que as informações contidas nos produtos possam ser lidas e compreendidas para o seu consumo. Não se pretende, com esta quantidade de informações, efetuar revolução ou mudanças que transformem as condições de vida social e política, pois os excluídos permanecerão excluídos, só que agora na condição de consumidores necessários ao sistema capitalista para a sua contínua produção de mercadorias de consumo.

Além da separação em classes, entre aqueles que possuem o capital e os que não possuem, existe a nova divisão que se dá entre aqueles que sabem ler e os que não sabem, entre o analfabeto funcional (muitas vezes com o diploma na mão) e aqueles que possuem "capacidade" de entendimento e de manobra maior da política econômica e financeira da sociedade. Ao falar de capacidade estamos nos referindo exatamente aos dois elementos que a tecnologia da produção requer: a capacidade entendida como força muscular (trabalho braçal), daí a proliferação do estímulo a exercícios físicos, para permitir que o corpo esteja sempre em boa forma; e a capacidade intelectual, tão necessária ao desenvolvimento tecnológico de ponta. Busca-se assim, através do treinamento pessoal, desenvolver as novas habilidades, como o bom relacionamento e novas formas de lidar com situações sociais complexas.

Poderíamos chamar a divisão entre os que possuem conhecimento e possibilidades de manobra e os que dispõem apenas da força de trabalho de nova forma de estratificação social, que se origina das transformações da informação e se expande pelo mundo. Nem todos estão à altura de decodificar a quantidade de informações veiculadas diariamente pelos meios de comunicação (jornal, internet, televisão, etc). Devido a esta onda de informações, espera-se que a escola não renuncie à tarefa de transmitir, pensar e repensar, de geração em geração, os conhecimentos necessários para a formação de cidadãos que demonstrem compromissos com a superação constante das desigualdades e exclusões que as recentes revoluções vêm aprofundando. É fundamental analisar a qualidade das informações veiculadas nos espaços escolares e 
velar "pela preservação dos registros da produção material e cultural [...], e pela memória das lutas dos povos na busca da superação das condições de escravatura, servilismo, exploração e exclusão da maioria dos homens" (Gamboa, 2001, p. 93).

O desafio da educação consiste também, em nossos dias, no combate à política da banalização do mal da irracionalidade, que leva a um servilismo alienado do indivíduo. Isso dificulta alcançar a formação integral, (política, social, cultural, etc) do homem angolano. Este tipo de formação passou a distanciar-se cada vez mais, tornandose utópico seu alcance. Urge então analisar as contradições que a sociedade capitalista nos apresenta e, a partir daí, procurar perceber quais seriam as possíveis saídas para uma educação diferente daquela voltada exclusivamente à formação da força de trabalho, e sim preocupada com a formação de homens capazes de entender a relação do seu trabalho com a vida política, social e econômica.

A inserção do país ao "mundo da globalização" - que segundo Beck, (1999, p. 13) "não aponta agora para o fim da política, mas sim para a exclusão da política do quadro categorial do Estado nacional e até mesmo do papel esquemático daquilo que se entende por ação política ou não-política" - levará a mudanças, no sistema de produção e na política nacional, sobretudo quando se tratar de decidir as formas ou técnicas sobre as quais ir-se-á efetuar a produção, isto é, onde e como produzir sem, no entanto, gastar mais do que se pode e render maior lucro possível.

É preciso compreender que, à medida que o poder de decisão dos Estados nacionais parece diminuir, diante de um poderoso "proto-estado-global que representa os interesses da nova divisão de classes da sociedade global" (Gamboa, 2001, p. 96), a política econômica e financeira desta instância global ganha maior espaço, pois, acaba se constituindo como prioridade acima do nacional. Por outras palavras, tal como encontramos uma instância de poder, no Estado nacional, também temos a presença de um poder que parece estar acima do nacional, aquele que decide por aspectos internacionais. Por exemplo, o Banco Mundial, o Fundo Monetário Internacional, o chamado Grupo dos Oito (G8), composto por países mais ricos e alguns outros organismos internacionais, representam exatamente este poder internacional, uma vez que interferem, com suas decisões, nas políticas nacionais, impondo suas normas, mesmo que estas não sejam as mais adequadas para o país em que se pretende implementar tais normas de produção. 
Há uma tendência de padronização das políticas de investimentos por parte dos organismos internacionais, no que tange às prioridades e normas de investimentos para o desenvolvimento da educação básica. Com isso as políticas econômicas e financeiras limitam os países do Terceiro Mundo não só a meros produtores da matéria prima como também a fornecedores de mão de obra barata. O que se pretende não é simplesmente efetuar a importação e exportação de bens de consumo ou investimentos entre diversas economias nacionais, mas de "uma nova divisão do trabalho entre as empresas multinacionais. A norma é: produzir onde os salários são os mais baixos, investir onde as leis são as mais generosas e usufruir lucros onde os impostos são menores" (Gamboa, 2001, p. 97). Por outro lado, nas novas leis do mercado global, segundo Beck (1999, p. 15) em que o trabalho pode e deve ser reduzido para que cresçam os lucros, "quem incentiva o crescimento da economia, produz desemprego no final. Quem reduz impostos e com isso aumenta as possibilidades de lucro também produz desemprego da mesma forma".

Uma parcela maior de pessoas fora do mercado de trabalho possibilita o barateamento do valor e tempo fornecido pelo trabalhador e, ao capitalista, resta maior lucro. A implementação de políticas como a de formação de capital humano, “dirigida pelo Proto-Estado Mundial, por intermédio do Banco Mundial, do FMI e UNESCO. [...] prioriza a formação técnica, desprezando o potencial humano para a criatividade e a produção científica" (Gamboa, 2001, p. 99). Não se tem por objetivo, na educação técnica básica, destinada à população em geral, a inovação cientifico-tecnológica, pois, se assim fosse possível, desequilibraria o sistema capitalista. Portanto, representa um perigo ao poder hegemônico permitir que qualquer país desenvolva inovações científicas e tecnológicas de ponta. A tecnologia de ponta "não precisa" ser desenvolvida por todos, importa apenas criar condições favoráveis que garantam melhores lucros ao capital internacional e, se possível, com menos ou sem impostos.

Os desdobramentos das novas formas ou jogos de forças e da racionalidade fazem com que os Estados nacionais do Terceiro Mundo se limitem a cumprir as regras ditadas pelas potências mundiais; impossibilitados pelas grandes dívidas no setor financeiro internacional eles acabam assumindo as diretrizes do Banco Mundial para formação do capital humano. Por outro lado, as medidas do Banco Mundial, do Fundo Monetário Internacional e dos chamados G8 (países ricos), também têm levado os Estados nacionais a transferirem para o setor privado suas 
responsabilidades de políticas públicas, como a educação, saúde e outros setores que o Estado "não consegue" manter. Desta forma a educação:

\footnotetext{
entendida no ideário iluminista como um direito para todos e uma forma de construção das sociedades nacionais, hoje, perante a crise da racionalidade iluminista e dos Estados-Nação, só tem sentido como um investimento nas habilidades e competências técnicas dos indivíduos, visando seu melhor desempenho no mercado de trabalho, ou como um bom negócio para os investimentos capitalistas na venda de uma nova mercadoria para a qual, potencialmente, tem uma grande massa de consumidores necessitados de treinamento técnico-profissional (Gamboa, 2001, p. 100).
}

A qualidade defendida pelo sistema se estrutura em torno do componente intelectual, isto é, no conhecimento da estrutura política e financeira. A partir daí, efetua-se a reestruturação do trabalho e se exige a formação das novas habilidades e competências para a nova geração de trabalhadores. Isto não significa que, ao se formarem - a nova geração de trabalhadores -, todos terão emprego garantido, ao contrário, constata-se que cada vez mais é "reduzido o número de trabalhadores qualificados que dispõe de um emprego estável, com acesso garantido a boas condições de assistência social" (Bernardo, 1998, p. 59).

Dentro do sistema capitalista, o papel da educação está limitado a inventar e reinventar continuamente seus propósitos políticos, de acordo com as exigências do mercado e da tecnologia, que requer conhecimentos, por parte do trabalhador, habilidades manuais, capacidades de tomadas de decisão e de assimilação dos novos códigos da informação, desligados daqueles propósitos de uma educação do homem como fim último de todas as coisas. Perdeu-se a idéia do homem que não pode ser tratado como meio por possuir uma dignidade, e passou-se a priorizar o homo faber, desvinculado do homem pensante, feito da relação teoria/prática e vice versa.

Em suma, a situação que Angola atravessa requer a defesa de um futuro e de um presente em que o sistema educacional abra, para todos os jovens, oportunidades de busca de entendimento histórico-cultural do país, perspectivando a construção de uma unidade sólida, ainda que esta não comporte uma realização imediata. Com isto, espera-se que a relação, crescimento e desenvolvimento econômico e eficácia educacional caminhem no sentido de permitir ao homem angolano a conquista 
de uma estabilidade e desenvolvimento sócio-cultural e a garantia dos direitos e deveres fundamentais. Há que partirmos dos valores culturais do país para determinar os pressuposto da reforma educacional, as formas de produção, e o desenvolvimento econômico, político e social.

\section{2 - Desenvolvimento econômico e a eficácia educacional}

O pensamento de que o crescimento e desenvolvimento econômico contribui para a melhoria da sociedade, como um todo, é aceitável na medida em que o crescimento econômico influi sobre a política educacional, isto é, apresenta uma relação direta com o sistema educacional, isto porque, como nos parece, é difícil chegar a um sistema educacional de "alta qualidade" sem investimento financeiro ou sem uma estratégia política que viabilize e impulsione o ensino e a pesquisa, tendo como conseqüência a melhoria do sistema econômico e educacional e da própria condição de vida em sociedade.

Assim sendo, precisamos ter em consideração, na análise, certas características institucionais, culturais, econômicas e sociais dos últimos trinta anos de Angola, pois, analisando do ponto de vista histórico, percebe-se que as desigualdades de acesso ao ensino e bens culturais públicos não são apenas resultados de um crescimento da demanda escolar ou da ausência de pessoal qualificado, como pensam alguns teóricos, para os quais bastaria o aumento da oferta de pessoal qualificado e a ampliação da capacidade do sistema educacional para inverter a situação. É necessário, antes de tudo, compreendermos a política de governo, isto é, ver se existem ou não "metas" de desenvolvimento social, cultural e político. Para a maioria da população angolana, neste momento, falar em desenvolvimento constitui um ideal "sagrado" e pedra angular da sociedade, pois com isso pensa-se na melhoria das condições de vida da maioria. Porém, é fundamental procurarmos compreender antes se o que as demais pessoas entendem por desenvolvimento significa o mesmo para o Estado angolano.

Quando, no discurso político, se fala em desenvolvimento e crescimento econômico, não significa necessariamente a melhoria das condições de vida, como o acesso ao ensino, saúde, água potável, moradia, etc., para "toda a população". Se estes aspectos aparecem no discurso é porque o sistema precisa deles 
para assegurar o poder que detém (mecanismos de manipulação). Assim, por exemplo, o termo democracia tornou-se palavra fundamental dentro de qualquer discurso, mesmo que, no final, não se tenha claro que tipo de democracia se defende. A constatação disto é possível quando comparamos a relação existente entre o discurso politicamente construído e defendido por quem detém o poder e a ação política empreendida no quotidiano, isto é, disseminada nas relações sociais.

Mesmo estando dentro deste contexto de contradição, entre o discurso e a ação política, entrelaçado no meio social, não deixamos de compreender a necessidade e a importância da construção ou planejamento de estratégias eficientes e metas a atingir que tornarem possível o desenvolvimento humano. Uma política de desenvolvimento poderia fundamentar-se no bem-estar do homem, na felicidade deste em sociedade. É certo que, para atingir tal desenvolvimento, haverá muitas dificuldades e sacrifícios, por se tratar de um país que acaba de sair da guerra. Porém, depois da guerra, as dificuldades e sacrifícios poderão ser "aceitas" em função de uma meta de desenvolvimento social a atingir a longo e médio prazo. Portanto, ou se traçam planos e metas eficazes e, com isso, se efetua um investimento sério no setor educacional, ou as coisas continuarão como estão e, neste caso, não caberá mais analisar a eficiência da política administrativa e governamental do Estado, nem falar em ou "sonhar" com um desenvolvimento humano.

O investimento na educação é importante na medida em que, com a globalização, exige-se da sociedade um domínio elevado do conhecimento, dos meios de informação, da tecnologia, da ciência e da própria cultura. Requer-se do homem um saber $^{64}$ "qualificado", para lidar com situações complexas que a sociedade apresenta uma vez inserida na política da globalização. Esta política se dá em grande parte sob forma de exploração, em que as leis são mais favoráveis ao capitalista e possibilitam, portanto, maiores lucros.

Alguns trabalhos que tratam do desenvolvimento econômico têm demonstrado a estreita "relação entre crescimento econômico e nível educacional” e a "alta correlação entre nível educacional de um país e nível de renda per capita"; outros têm indicado a educação como "importante fator explicativo das taxas de crescimento da renda nacional” (Gremaud, 2003, p. 500). O que se pode perceber da lógica por trás

\footnotetext{
${ }^{64} \mathrm{Na}$ sociedade atual, o saber está cada vez mais restrito àqueles que procuram desenvolver a tecnologia de ponta e esta requer, por parte da empresa, maior investimento de seu capital financeiro.
} 
dos resultados destes trabalhos é que, países como Angola apresentam escassez relativamente alta de mão-de-obra qualificada. Argumenta-se que, sem esta mão-deobra, que somente pode obter-se por meio da educação formal, não seria possível o desenvolvimento da economia. Tem-se defendido também o aumento do investimento financeiro como forma de ampliar, além da oferta de trabalho, a formação de futuros trabalhadores.

Defende-se, para o crescimento econômico, medidas de ampliação da formação de profissionais (especializados), que possam contribuir para o crescimento econômico (melhoria da força de trabalho), criação de uma liderança intelectual apta a preencher os cargos oferecidos nos setores públicos e privados, criação de um tipo de treinamento e de uma educação que eliminasse o analfabetismo e habilitasse a força de trabalho e, ao mesmo tempo, a qualificasse para as atividades ditas "modernas"65. Todavia, é fundamental observarmos que a análise do papel da educação, no processo de desenvolvimento econômico, não pode restringir-se à análise de seu papel em uma única estatística, isto é, a taxa de crescimento do produto nacional. Faz-se jus analisar e pensar o papel da educação na distribuição dos benefícios do crescimento econômico.

Ampliar as vagas, em todos os níveis de ensino, não significa reduzir o diferencial existente entre a mão de obra especializada e a mão de obra nãoespecializada. Trata-se de uma visão mecanicista pensar que, uma vez ampliadas as vagas no sistema de ensino angolano, o mercado por si se encarregaria de reduzir as desigualdades, pois o sistema educacional angolano, neste momento, por si só seria incapaz de ser agente de eliminação das desigualdades sociais. A tendência à privatização do ensino poderá, de alguma forma, contribuir também para acentuar os "desequilíbrios" sociais, justamente porque as condições de acesso e sustento não estão minimamente acessíveis a todos, ou seja, quanto menor forem as possibilidades econômicas do indivíduo (estudante ou família) maior será a dificuldade em concluir seus estudos. A realidade angolana confirma claramente esta argumentação.

A solução do problema da pobreza e desigualdade depende diretamente de medidas políticas e econômicas de desenvolvimento e ampliação de acesso ao sistema educacional angolano. É possível pensarmos a relação entre desenvolvimento e educação a partir da ligação entre a estrutura do sistema educacional e a ordem econômica e social da sociedade angolana. $\mathrm{O}$ sistema educacional reflete as

${ }^{65}$ GREMAUD, A. P. et al. 2003, p. 500. 
características da sociedade e da política voltada à educação. A desigualdade, que se verifica na esfera econômica e social, reflete-se na educação, uma vez que esta esfera define, a priori, aqueles que poderão continuar e concluir o ensino pretendido, independente das competências individuais, reforçados pela lógica econômica e financeira.

Enquanto a estrutura econômica, social e institucional angolana for organizada de forma a satisfazer as necessidades e desejos de alguns poucos, com rendas mais elevadas, como é notório, o sistema educacional, ainda que em princípio, esteja aberto a todos, continuará na realidade a representar uma política de distanciamento cada vez maior entre ricos e pobres, pois, estar aberto a todos não significa disposição de condições econômicas para todos. Neste contexto, qualquer programa ou medida política que intenta tornar mais relevante a educação para o desenvolvimento precisará, em principio:

modificar os incentivos econômicos e sociais fora do sistema educacional, pois esses é que irão, largamente, determinar a magnitude, a estrutura e a orientação da demanda por educação e, conseqüentemente, a resposta política da forma de ampliação de vagas no sistema educacional público e, indiretamente, no sistema privado; modificar a eficácia e a equidade interna do sistema por meio de modificações apropriadas na orientação dos currículos e na estrutura existente de financiamento da educação (Gremaud, 2003, p. 508).

Entendemos que uma política que vise atingir simultaneamente estes dois objetivos poderia permitir estabelecer uma relação entre educação e desenvolvimento $^{66}$ econômico angolano. Outro aspecto fundamental para o desenvolvimento concerne aos conhecimentos científicos e culturais, elementos que impulsionam o avanço da sociedade. Estes conhecimentos se constroem e se desenvolvem através da investigação científica.

\footnotetext{
${ }^{66}$ Diferente do crescimento econômico, que está mais relacionado ao caráter cumulativo dos bens materiais ou da matéria prima, o desenvolvimento está mais relacionado ao caráter da perfeição: melhoria das técnicas de produção (tecnologia de ponta). A educação visa, entre outros, contribuir para melhorar as condições de entendimento das relações sociais, de trabalho e de convivência. Assim sendo, o crescimento do pensamento deve implicar numa reorganização total do sistema de saber para que haja melhoria na forma de questionar a realidade, de levantar problemas de pesquisa e de construir o conhecimento.
} 
É sobre a base da investigação científica e do desenvolvimento cultural humano que assenta a necessidade de uma política educacional de qualidade, que encontra nela mesma a justificativa de seu fim último. Neste sentido podemos entender o desenvolvimento da ciência como a via pela qual o homem poderá obter clareza de suas ações políticas e sociais, e quanto mais prática científica se efetiva, maior a contribuição para o desenvolvimento de diferentes racionalidades.

O ritmo de desenvolvimento científico e tecnológico requer uma inovação constante, que se dá pela pesquisa. É importante notar que a inovação depende, em parte, da demanda que a sociedade apresenta, da política educacional, do incentivo ao desenvolvimento humano e científico. A inovação leva à transformação do conhecimento em bens e serviços que atendem às necessidades da sociedade, e, justamente por isso, é necessária a intervenção do Estado (governo), isto é, o apoio econômico-financeiro para sustentar as infra-estruturas escolares e acadêmicas e a formação de seus quadros para pesquisa.

Tornar-se-ia mais difícil esperar que cada jovem angolano, que tem o desejo de ingressar à carreira acadêmica e de investigação científica, procurasse, por si mesmo, levar adiante um projeto inovador no ramo da ciência. Por esta razão a educação não pode ser deixada à sorte de cada um, ela deve desempenhar um papel na construção social, papel este que requer do Estado capacidade política e financeira para sustentar a implementação das propostas a serem delineadas.

Em suma, podemos dizer, nas palavras de Jorge (1998, p. 62), que Angola é sim um país do futuro, todavia, esse futuro "está intimamente ligado à qualidade das opções que forem feitas" hoje, pois, como se sabe,

O futuro de Angola, que em determinada época era prometedor foi comprometido, muitas vezes, pela mediocridade das opções do passado, pela ineficácia das opções do presente. As opções para o futuro devem, portanto, ter em conta não só análises abstratas e voluntarismos, sem relação com a realidade, mas a análise concreta do complexo geopolítico que é o país real (Jorge, 1998, p. 65).

A deficiência, até aqui constatada na gerência de propostas educacionais delineadas pelo Estado angolano, durante os últimos trinta anos, não pode ser imputada apenas às fraquezas humanas, que se manifestam na seleção do pessoal 
que desempenha determinada função no quadro do sistema de ensino, ministérios, etc., situação que levou grande número de "mediocridades" a desempenharem funções importantes nas universidades e faculdades ou instituições públicas. Deve-se buscar entender, antes de tudo, as relações que regem a cooperação humana entre organizações diversas, que, ao longo destes anos de independência, se procurou construir. Relações que permitiram ao indivíduo chegar a desempenhar esta ou aquela função em um determinado setor, instituição ou faculdade, mesmo não tendo conhecimento claro daquilo que lhe era exigido no cargo que ocupava. Estas relações permitem-nos compreender o porquê das deficiências e do não delineamento claro de uma política educacional capaz de desempenhar papel fundamental na consolidação da democracia angolana.

\section{3 - Educação democrática: um desafio político}

De 1975 a 2006 muitas mudanças ocorreram na esfera política, econômica e cultural. A população, aos poucos, foi construindo novas concepções a respeito do governo e dos partidos políticos. As relações entre as várias línguas existentes em Angola mudaram significativamente, e assuntos como direitos humanos, liberdade política ou partidária, circulação das pessoas e o direito de expressão têm tomado parte no discurso político quotidiano. No entanto, a nova realidade faz-nos ainda viver numa sociedade de privação e opressão extraordinária, o que nos permite perceber que existem problemas antigos (desde a independência) convivendo com os novos. Assim sendo, a abordagem da educação democrática é aqui entendida como forma ou mecanismo político que consiste na ampliação dos espaços escolares, do acesso ao ensino (em todos os níveis) e das condições econômicas necessárias ao desenvolvimento sociocultural das pessoas.

O desafio político que a atual realidade angolana apresenta consiste, de acordo com as lutas de classes estabelecidas, em fazer com que as oportunidades sociais estejam disponíveis a todos e que o crescimento e desenvolvimento econômico contribua, do ponto de vista político, tanto para a "eliminação de privações de liberdade que limitam as escolhas e as oportunidades das pessoas exercerem ponderadamente sua condição" de cidadão, como para a criação de "oportunidades sociais de educação e 
assistência médica, que podem requerer a ação pública" (Sen, 2000, p. 10), visando diversificar as oportunidades de participação social, econômica e cultural e ultrapassar as privações existentes.

É condição fundamental de desenvolvimento criar espaços de discussão pública como "veículo de mudança social e progresso econômico" (Sen, 2000, p. 12) e oportunidades econômicas para a população. Liberdade política e partidária, garantia da transparência administrativa e governamental, segurança protetora do Estado, etc. são aspectos que necessitam estar presentes na discussão constante para superação gradual das desigualdades no país.

O desenvolvimento pode ser visto como um processo pelo qual se expandem as liberdades reais de que as pessoas podem desfrutar dentro da sociedade, pois direitos e oportunidades ajudam a promover a capacidade geral das pessoas em sociedade e a desenvolver melhor o espírito de democracia. Portanto, estes são aspectos essenciais do desenvolvimento:

- $\mathrm{O}$ crescimento do Produto Nacional Bruto (PNB)

- O aumento da renda pessoal de acordo com a realidade do país nível de vida social

- O impulso do avanço tecnológico (modernização dos meios de produção).

- O avanço de nível escolar/acadêmico - nível cultural do país

- A consolidação da democracia e a independência dos três poderes no exercício de suas atividades e aplicações das devidas medidas políticas de controle e equilíbrio

- O controle da inflação e a regularização da moeda nacional segurança econômica

- As disposições socioeconômicas, garantias dos direitos civis participar das discussões e averiguações públicas.

Angola necessita ultrapassar vários obstáculos resultantes da guerra, da má administração e do uso dos bens públicos, como também enfrentar novos desafios que o desenvolvimento humano implica. E como mostra João P. Guerra (2002) Angola deve, hoje, superar: 


\begin{abstract}
Uma economia devastada pela guerra, a instabilidade macroeconómica e o aumento da dívida externa; uma economia desordenada, que situa um país de riquíssimos recursos nos últimos lugares da escala mundial do rendimento per capita - $160^{\circ}$. em 174 países -, com circuitos comerciais assentes em mercados paralelos e uma corrupção generalizada; infra-estruturas urbanas e rurais destruídas, quer por efeito directo de acções de guerra, quer pelo abandono dos campos e o fluxo brutal de populações aos centro urbanos onde gozam de um mínimo de proteção (Guerra, J. P., 2002, p. 260).
\end{abstract}

Assim postos os obstáculos, percebe-se que a educação da atual geração angolana precisa atender a objetivos como: a) dar formação humanística ao homem, enquanto ser social e político; b) permitir ao cidadão a obtenção de meios de ação para o seu bom andamento e desenvolvimento; c) atender ao progresso sociocultural para superar problemas constantes na sociedade; d) contribuir na implementação de medidas que visam propiciar a criação de espaços e possibilidades de desenvolvimento da democracia e da paz; e) mudar a formação de professores, considerando o papel que estes terão de desempenhar na atual conjuntura política - de consolidação das instituições democráticas no país; f) libertar os professores existentes do sistema que os impede de participarem ativamente no acesso e produção do conhecimento inovador, de desenvolverem a criatividade, a autonomia e crítica.

A discussão da educação democrática pode propiciar uma compreensão da situação de Angola, como um todo, sem no entanto, desconsiderar situações reais de cada província, para não cairmos no que Azanha (1992) chama de abstracionismo pedagógico $^{67}$, ou seja, no "processo de escamoteamento do real pela via - ingênua ou astuciosa - da discussão abstrata mascarada de discussão teórica” (p. 43). Ainda segundo Azanha (1992)

muitas vezes, o abstracionismo é apenas uma forma ingênua de encaminhamento do exame de um assunto, no qual o estudo da realidade é substituído por um jogo verbal semanticamente vazio. Outras vezes, porém, o

\footnotetext{
${ }^{67}$ Referimo-nos ao sentido negativo da abstração, aquele que procura separar e tomar como autônomos e independentes os aspectos sociais inseparáveis. Trata-se de aspectos (conteúdos) dados ao mesmo tempo "numa relação de parte-todo, de modo que sua separação elimina a própria possibilidade de conhecimento" (Azanha, 1992, p. 43).
} 
abstracionismo mais parece ser um claro golpe de astúcia, ideológica ou não (Azanha, 1992, p. 43).

Também faz parte dos desafios a enfrentar a implementação de uma política que materialize "um sistema educacional que abra a todos os meninos e todas meninas as melhores oportunidades possíveis" (Russell, 1977, p. 7) e, ainda segundo Russell, este "sistema ideal de educação deve ser democrático, embora não comporte a realização imediata" (Russell, 1977, p. 8). A democracia a que nos referimos consiste também, além da abertura de oportunidades de acesso a um sistema educacional de qualidade, na criação de condições econômicas favoráveis a todos os cidadãos.

Temos consciência das dificuldades que um ensino democrático enfrenta, e sabe-se que, entre os professores que trabalham na educação, não são todos que demonstram maior interesse e responsabilidade no desenvolvimento de programas voltados à democracia de Angola. O desafio consiste na luta pela superação dos impasses postos pela política de governo pautada em princípios não democráticos, fruto da visão política de "partido único". Necessitamos assim de uma revolução que permita alterar as condições de vida social e as relações de propriedade ${ }^{68}$ existentes.

A educação pública qualificada e democrática é a desejável para a maior parte da população, mesmo que tal propósito pareça "impossível" diante da situação presente, do resultado da guerra e do pouco compromisso político com o ensino do país. É fundamental que as novas metodologias de educação democrática se espelhem por todo o país e que as novas formas e descobertas possam ser desenvolvidas para o contínuo progresso da ciência e das condições sociais humanas.

Entendemos que, sem cidadãos com conhecimentos filosóficos, científicos, responsabilidade política e ética, unidas à construção de uma sociedade humana, não será possível concretizar-se a democracia em Angola. Urge, assim, apontar para uma nova crítica social do atual sistema político e de poder, de seus mecanismos de controle e manutenção da ordem social.

${ }^{68}$ É fundamental uma discussão política da propriedade privada (na atual sociedade angolana) que permita estabelecer um certo equilíbrio social como condição fundamental para o desenvolvimento da democracia. Os que se apropriaram da riqueza do país e do poder parecem estar de acordo com a ideologia explicativa da desigualdade social, econômica, política e cultural, como se isso fosse algo inerente ao ser humano: fruto das diferenças climáticas ou dos "desígnios divinos". O que não corresponde à verdade senão para justificar a injustiça causada pelo sistema de acumulação do capital, que procura desprover-se da responsabilidade social. 
O processo pedagógico não pode ser entendido, apenas, como aplicação de técnicas ou metodologias, deve também estar relacionado aos conteúdos científico-filosóficos que permitem ao indivíduo um desempenho maior como ser social e político. A luta passa pela defesa de uma educação que torne possível o propósito de convivência social democrática sem injustiça. A educação para a democracia constitui condição fundamental do processo de desenvolvimento social, e isso requer, por um lado, a eliminação de problemas que afetam o sistema administrativo e, por outro, a consideração da liberdade e da responsabilidade política dos cidadãos como parte fundamental do compromisso sociocultural.

\section{4 - A garantia do direito à educação}

A razão pela qual se justifica uma indagação filosófica, a respeito da garantia dos direitos sociais $^{69}$, deve-se à necessidade, por parte do homem, de compreender e dar um sentido à sua vida política, cultural, histórica e econômica. E isso nos obriga a reconhecer o homem, de uma forma geral, como um ser de direitos e deveres. A garantia de direitos depende dos mecanismos institucionais que estão sob o poder do Estado e se materializam através das políticas públicas de distribuição de renda, acesso aos bens culturais públicos, à saúde, educação e trabalho.

Os direitos humanos representam uma resposta política que visa limitar o excessivo abuso do poder, pois, como a história da humanidade tem-nos demonstrado, segundo Comparato (2001, p. 1), a "proteção da dignidade humana depende, fundamentalmente, da solução de um problema, cuja magnitude representa um desafio à argúcia dos governantes de todos os tempos: como pôr o direito acima da vontade dos homens". Se o abuso do poder representa também, uma causa primeira da desordem ética, então a função primordial da ordem jurídica deve consistir em refrear a "liberdade natural, que conduz ao conflito e ao senhorio dos mais fracos pelos mais fortes, a fim de se instaurar a liberdade política, fundada no mútuo respeito da pessoa

\footnotetext{
${ }^{69}$ Quando falamos de direitos sociais estamos nos referindo exatamente à educação, trabalho - com um salário adequado -, distribuição econômica e saúde, aspectos necessários e fundamentais à convivência digna entre as pessoas. É para estes direitos, necessários à condição humana à garantia e à responsabilidade política, que está voltada nossa atenção de forma geral e em especial à educação.
} 
humana, em todas as suas múltiplas diferenças biológicas e culturais" (Comparato, 2001, p. 1).

Aspecto também importante, com o qual nos deparamos ao discutir políticas de garantia dos direitos sociais, é a forma surpreendente com que dirigentes políticos, com ajuda dos meios de comunicação de massa, procuram injetar na sociedade a imagem da banalidade do mal, como afirma Arendt (2004) na obra Responsabilidade e Julgamento, "sob uma aterradora aparência de normalidade, a mesma tanto para a fabricação de alimentos como para a manufatura de cadáveres".

Concordamos que, para haver compromisso com a política de garantia do direito à educação, o controle ou denúncia da violação do mecanismo internacional dos direitos sociais, econômicos e culturais das pessoas não pode restringir-se à sistemática forma de relatórios " "denunciadores". É preciso que se criem mecanismos jurídicos capazes de levar ao julgamento, tal como o direito positivo, e a condenar o não cumprimento das diretrizes (leis) de defesa e garantia dos direitos. Para tal pensamos que é fundamental que um poder refreie outro (jurídico, executivo e legislativo) para permitir que não haja abuso de poder, ou seja, segundo Comparato, é necessária uma disposição das coisas, vale dizer "pela organização das instituições políticas, não pela vontade dos homens" (Comparato, 2001, p. 1).

Um dos desafios que se apresenta, depois que o governo angolano adotou o sistema de economia de mercado ou capitalista (da acumulação do capital desprovida de qualquer responsabilidade social), é pensar o seguinte: até que ponto o governo poderá garantir o direito à educação e, de forma geral, os direitos sociais e em que medida se pode exigir dos dirigentes maior responsabilidade política pela defesa da condição humana?

Trata-se de uma exigência política da sociedade em vista da defesa de um bem maior que é a própria vida humana. Toda ação política de Estado requer responsabilidade e luta pela garantia dos direitos sociais (educação, trabalho e saúde). A responsabilidade política deve constituir prioridade para o Estado, permitindo, com isso, a manutenção da paz, a compreensão entre os homens e a preservação da dignidade

\footnotetext{
${ }^{70}$ A defesa da garantia dos direitos sociais por parte das Nações Unidas em relação aos Estados Nacionais não deve se limitar simplesmente à denúncia, mediante relatórios que a eles são apresentados. É salutar sim, que haja ou que se criem mecanismos suficientemente sustentados, a partir dos quais se possa exigir melhor, dos Estados Nacionais, responsabilidade e garantia dos direitos sociais.
} 
humana. Esta constitui o fim último, pelo qual, a luta pela política da garantia dos direitos tem uma razão de ser.

A responsabilidade política se manifesta na forma como o governo se posiciona na luta pela garantia ou não dos direitos sociais enquanto elementos-chave da defesa da dignidade da pessoa. A exemplo disso vê-se os Estados Unidos da América, que apesar de mostrarem-se como "verdadeiros" defensores dos direitos humanos e da democracia, por outro lado, possuem um congresso que rejeitou a ratificação do "Pacto gêmeo sobre direitos econômicos, sociais e culturais",71 (Comparato, 2004, p. 532), que permite aos países maior liberdade de aplicação dos seus recursos financeiros e desenvolvimento. Os três princípios fundamentais - liberdade, igualdade e fraternidade apontados pelo Artigo I da Declaração Universal dos Direitos Humanos, deve fazer com que países como EUA e outros mudem certas posições políticas voltadas à acumulação de capital em detrimento de outros.

Falarmos em solidariedade constitui também um aspecto complexo, pois, como se sabe, se os países desenvolvidos estivessem realmente interessados na garantia dos direitos sociais e na eliminação de problemas sociais em vários países da África, Ásia e América Latina, não teriam intensificado suas políticas, nos últimos quinze anos, de vendas elevadas de armamentos, pois tanto o desenvolvimento humano como o dos três princípios fundamentais não se concretizam através da venda de armamentos que, ao contrário, somente contribui para o crescimento de conflitos, desrespeito contínuo à própria pessoa e banalização do mal.

Está aqui um exemplo de contradição entre o que se prega e o que se faz a favor da defesa dos direitos fundamentais. Defendemos a idéia, de que a educação deve visar à tomada de consciência e mudança de mentalidade em favor da convivência política e cultural. A educação dos direitos humanos tem, assim, uma razão de ser em função da defesa da dignidade da pessoa como fundamento primordial de toda luta política e social.

\footnotetext{
${ }^{71}$ Segundo o "Pacto Internacional sobre os Direitos Civis e Políticos", Parte I, "Art. 1'. § 1: Todos os povos têm direito à autodeterminação. Em virtude desse direito, determinam livremente seu estatuto político e asseguram livremente seu desenvolvimento econômico, social e cultural. 2. Para a consecução de seus objetivos, todos os povos podem dispor livremente de suas riquezas e de recursos naturais, sem prejuízo das obrigações decorrentes da cooperação econômica internacional, baseada no princípio do proveito mútuo, e do Direito internacional. Em caso algum, poderá um povo ser privado de seus meios de subsistência". In: Comparato, 2004, p. 281.
} 
Responsabilidade política e garantia dos direitos sociais constituem pontos fundamentais de discussão política e econômica na atualidade, tendo como objetivo a efetivação da democracia, respeito à dignidade da pessoa e à convivência mútua. Tudo isto constitui um desafio político para os Estados comprometidos com os direitos humanos e, sobretudo, para as Nações Unidas, que precisam melhorar os mecanismos de cobrança e exigência da efetivação dos direitos à educação. Como afirmam os autores Piovesam, Gotti e Martins, para a implementação dos Direitos Econômicos, Sociais e Culturais, aprovados em 1966 pelo Pacto Internacional,

\footnotetext{
emerge o desafio da construção de um novo paradigma, pautado por uma agenda de inclusão, que seja capaz de assegurar um desenvolvimento sustentável, mais igualitário e democrático, nos planos local, regional e global. Ao imperativo da eficácia econômica deve ser conjugada a exigência ética de justiça social, inspirada em uma ordem democrática que garanta o pleno exercício dos direitos humanos (Piovesam, F.; Gotti, A. P.; e Martins, J. S. 2003, p. 109).
}

Responder pelos atos políticos para garantir os direitos sociais representa um desafio na sociedade capitalista que, a todo o momento, procura estimular as pessoas ao consumo individualizado e excludente. Nota-se constantemente uma separação entre cultura e economia, mundo instrumental e mundo simbólico. Cada um é responsável por si mesmo e luta pela garantia de seus "direitos" mesmo que seja em detrimento de outrem. Já não se identifica mais a pessoa de direito como responsabilidade política coletiva ou social do Estado, mas do indivíduo em particular.

De forma geral, falar em globalização passou a significar que as tecnologias, instrumentos e mensagens estão presentes por toda parte, mas sem estarem ligados a nenhuma cultura particular. Essa dissociação da cultura de massa, Segundo Touranine (2003, p. 10), “faz com que vivamos juntos apenas à medida que fazemos os mesmos gestos e utilizamos os mesmos objetos, mas sem sermos capazes de nos comunicar além da troca dos signos da modernidade".

A preocupação que Alain Touraine apresenta na sua obra - Podemos viver juntos? - está voltada a uma análise peculiar da atualidade, onde a ideologia da mundialização da economia nos mistura diariamente nos supermercados da informação e do consumo, mas não nos ajuda a compreendermo-nos e, quando se tenta sair dessa 
situação em busca de outros caminhos para nos refugiarmos em nossa identidade ou comunidade, acaba-se inevitavelmente, negando a presença daquele que nos parece ser uma "ameaça", por ser diferente. Ao mesmo tempo em que se luta por uma identidade homogênea (globalizada), nega-se aquele que não se enquadra nestes "parâmetros de homogeneidade".

Será possível a plena efetivação e vivência dos direitos sociais? Quem deve ter a responsabilidade de propiciar isso? Será que para vivermos juntos, necessariamente teremos que, aos poucos, perder nossa identidade ou então permanecer preservando nossa "identidade /comunidade" dos demais - diferentes - através da luta? Segundo Touraine,

\footnotetext{
É verdade que vivemos um pouco juntos em todo o planeta, mas é igualmente verdade que por toda parte se reforça e se multiplicam os grupos de identidade, as associações baseadas na pertença comum, as seitas, os cultos e os nacionalismos; as sociedades voltam a ser comunidades reunindo estreitamente, num mesmo território, a sociedade, a cultura e o poder sob uma autoridade religiosa, cultural, étnica ou política que se poderia chamar carismática, pois ela não encontra a sua legitimidade na soberania popular, na eficácia econômica ou na conquista militar, e sim nos deuses, nos mitos ou nas tradições duma comunidade. Quando estamos todos juntos, não temos quase nada em comum; e quando partilhamos crenças e uma história, rejeitamos os que são diferentes de nós (Touraine, 2003, p. 10-11).
}

Assim sendo, a idéia tão sedutora do famoso melting-pot mundial, segundo a qual todos faríamos parte do mundo unido, não é nada mais que a ideologia adocicada dos empresários de espetáculos mundiais que procuram levar ao mundo uma imagem que esconde os conflitos sociais, a miséria, as guerras destruidoras, o desrespeito humano e a irresponsabilidade dos órgãos públicos e políticos em relação à garantia dos direitos de defesa da dignidade humana.

Nas lutas políticas encontramos as contradições que possibilitam fazer uma releitura filosófica para entender e encontrar possíveis caminhos da responsabilidade política pela garantia dos direitos sociais. Como mostra Touraine, nestas lutas está presente um dilema: 
$\mathrm{Ou}$ reconhecemos uma independência plena para as minorias e as comunidades, contentando-nos a fazer respeitar as regras do jogo, os procedimentos que garantem a coexistência pacífica dos interesses, das opiniões e das crenças, renunciando, porém, ao mesmo tempo, à comunicação entre nós, pois não nos reconhecemos mais em comum exceto não proibir a liberdade dos outros e participar com eles em atividades puramente instrumentais; ou acreditamos que temos valores em comum [...] (Touraine, 2003, p. 13).

A responsabilidade política, numa sociedade que se pretenda falar em cidadania e democracia, deveria fazer com que tanto os dirigentes, como os eleitores, tivessem a atenção voltada para um ideal comum de dignidade humana e de vivência social. Parece-nos difícil conceber uma cidadania "democrática" em que, por exemplo, os dirigentes estão de olhos voltados para o exterior, o mercado mundial e a acumulação de capital econômico, sem responsabilidade social no país que governam, e os eleitores, com uma visão voltada para o privado, o consumo individualizado.

Cada pessoa singular tem a sua própria responsabilidade segundo a medida ou grau de participação, consciente e livre na ação. E esta responsabilidade pessoal não pode ser transferida para um conjunto de pessoas até desaparecer. É legalmente aceitável que se exija do Estado a garantia de políticas públicas, a institucionalização de mecanismos jurídicos que assegurem a plena defesa do direito à educação como também da política democrática.

Desta forma o discurso político ou contribui para perpetuar o sistema de exclusão e, com isso, continuar com o "processo da naturalização" do sofrimento, da fome e miséria resultantes da guerra e das exorbitantes desigualdades sociais, ou mudamos de rumo passando a ter o homem e sua condição como ponto de referência principal. E com isso, o trabalho educativo deve contribuir para o entendimento humano e a unidade angolana. Entendemos que a escola não deve ser lugar de "lavagem cerebral",72, onde as crianças entram em suas mais diversificadas formas e saem todas enfileiradas (iguais ideologicamente), passando a pensar as coisas não de uma forma crítica, consciente e livre, mas sim como o sistema quer que elas pensem (alienadas).

\footnotetext{
${ }^{72}$ Com isso não estamos entendendo a escola como uma instituição neutra nem tão pouco pretendemos aqui apresentar uma defesa da neutralidade da escola. Sabemos que a escola é uma das instituições reprodutoras da política vigente, defendida pelo Estado. Todavia, é nas lutas e contradições provenientes da política vigente que podem dar-se as possibilidades de entendimento diferenciado, isto é, criar possibilidades de ver o que está posto a partir de uma outra perspectiva.
} 
Longe de promover a "libertação" das concepções negativas, construídas ao longo da história de guerra, como o desrespeito humano e a banalização do mal, o que tem sido feito pelo discurso ideológico de luta pelo poder é levar as pessoas a não pensarem por si mesmas e, com isso, perpetua-se a desigualdade social. Distraem-se as "mentes" (pessoas) com as propagandas e o consumismo e tomam-se medidas educacionais paliativas.

Rito Dias, quando se referia a uma das cidades de Angola destruída pela guerra civil entre a UNITA (União Nacional para a Independência Total de Angola) e o MPLA (Movimento Popular de Libertação de Angola), dizia:

\author{
[...] Aqui os velhos perderam a memória, \\ os jovens perderam os braços. \\ - Só as crianças fazem pergunta. \\ Aqui a verdade não tem rosto, \\ As lágrimas não tem olhos. \\ - Só a guerra tem direito ao sol \\ [...] Aqui só as manhãs voltam sempre, \\ só as montanhas são as mesmas, \\ - Só os pobres cantam a morte. ${ }^{73}$
}

Por que falarmos em responsabilidade política do Estado se este, cada vez mais, se responsabiliza menos pela questão dos direitos sociais? É fundamental que exista um mecanismo objetivo de organização política do Estado para a garantia dos direitos à educação. Do funcionamento desses mecanismos depende a aplicação das próprias garantias judiciais, pois, como se sabe, a falta de responsabilidade se manifesta nas várias formas aperfeiçoadas de exclusão e de discursos.

\title{
5 - A defesa da dignidade humana pela educação
}

O homem pode converter-se no mais divino dos animais, sempre que se eduque corretamente; converte-se na criatura mais selvagem de todas as criaturas que habitam a terra, em caso de ser mal-educado.

Platão. As Leis, 1766a.

\footnotetext{
${ }^{73}$ RITO DIAS, 1997, p. 13.
} 
O grande fundamento que podemos encontrar para justificar a garantia do direito à educação é a própria pessoa humana e sua dignidade. E aqui concebemos dignidade como condição fundamental para a vida social e política. Ela está intimamente relacionada à dimensão da participação na vida pública, liberdade e justiça social. Esta última é necessária na medida em que existem desigualdades diante da lei, dos direitos e acesso aos bens econômico públicos. Segundo Comparato (2004), a

\footnotetext{
dignidade da pessoa não consiste apenas no fato de ser ela, diferentemente das coisas, um ser considerado e tratado, em si mesmo, como um fim em si e nunca como um meio para a consecução de determinado resultado. Ela resulta também do fato de que, pela sua vontade racional, só a pessoa vive em condições de autonomia, isto é, como ser capaz de guiar-se pelas leis que ele próprio edita (Comparato, 2004, p. 21).
}

A pessoa não tem preço como as coisas, mas sim dignidade, e é esta que precisa ser defendia pelos direitos humanos e garantida pelo Estado.

Podemos apreender o princípio fundamental da dignidade humana, anunciado por Kant, como segunda fórmula do imperativo categórico que afirma o seguinte; "age de tal forma que trates a humanidade, tanto na tua pessoa como na pessoa de qualquer outro, sempre também como um fim e nunca unicamente como um meio"74. Este imperativo estabelece que todo homem, ou seja, todo ser racional, como fim em si mesmo, possui um valor não relativo. Em outras palavras podemos dizer que o homem possui um valor intrínseco que é a chamada dignidade.

$\mathrm{Na}$ sociedade tudo o que tem preço pode ser substituído por alguma coisa equivalente. Todavia, o que é superior a qualquer preço e, por isso mesmo não permite nenhuma equivalência, tem dignidade. E esta só ao ser humano pertence. Portanto, a humanidade não tem preço, e o ser humano é insubstituível. Desta forma, toda guerra, mesmo que justificada, precisa ter um responsável porque ela representa um atentado à dignidade humana. A questão que se coloca é: porque fabricar armas de grande porte, justificadas pela política de "defesa nacional"? Porque é que os mecanismos de defesa dos direitos humanos não tornam inviáveis o funcionamento das

\footnotetext{
${ }^{74}$ Abbagnano, Nicola. Dicionário de filosofia. 4 $4^{\mathrm{a}}$.ed. São Paulo. Martins Fontes, 2000.
} 
indústrias de fabricação de bombas atômicas, a propagação de doenças entre as pessoas com objetivos de "estudos", etc.?

A plena realização da dignidade humana deve significar ausência de todo tipo de desvalorização humana, preconceito e discriminação. A garantia dos direitos sociais poderá acontecer a partir do momento em que todo "cidadão" tiver pleno acesso à educação, saúde e trabalho digno. Sem estes três elementos, fundamentais a qualquer pessoa, falar em democracia ou "participação política" - que se limita ao voto não passa de uma simples forma de domínio das classes que detêm o poder econômico sobre os menos favorecidos.

A luta pela igualdade diante da lei deve tornar possível a construção de uma sociedade em que se estruture o direito à vida digna, ou seja, como dizia Odalia (2003, p. 162), na sua obra “A liberdade como meta coletiva”, "é necessário concretizar e tornar pública essa possibilidade pela declaração de que os homens nascem iguais".

A luta pela dignidade do homem através dos direitos humanos permanece como processo histórico em crescimento. Neste processo a educação tem um papel de caráter fundamental, isto é, permitir a compreensão do meio social, político e cultural. Ao professor compete, além de ensinar, criar possibilidades de crescimento de seus alunos numa visão global de dignidade e de responsabilidade política e cultural.

A qualidade administrativa do governo percebe-se através da forma como ele estrutura, organiza e implementa sua política de direitos na sociedade, e pela maneira das pessoas se relacionarem. A partir da organização e das formas de estruturação da sociedade, percebe-se o tipo de política e educação a que o país está submetido. O Estado é o "agente central do crescimento e da justiça" e, mesmo sendo "atacado de um lado pela internacionalização da economia, do outro lado pela fragmentação das identidades culturais" (Touraine, 2003, p. 20) ele continua sendo o articulador principal da política para a garantia dos direitos sociais.

Conforme dissemos anteriormente, o crescimento e o desenvolvimento econômico não podem dissociar-se do aspecto educacional, social e cultural. E o direito civil e político não pode estar acima do direito à educação, saúde e trabalho, garantias e responsabilidades como forma de atender aos interesses da demanda ou do chamado "mercado capitalista". Segundo Touraine (2003) o 
mercado por si mesmo não traz um modelo de regulação social, porque, se permite a diversificação das demandas e da adaptação da produção a essas demandas, se também traz consigo uma eliminação das barreiras tradicionais e dos sistemas autoritários de controle social, se permite, enfim, negociações coletivas e compromissos úteis, submete também as demandas dos consumidores a um sistema de oferta muito concentrado (Touraine, 2003, p. 21).

Entendemos que é fundamental a construção de bases educativas para o desenvolvimento da ciência, que possam contribuir para despertar a curiosidade por uma educação que liberte do preconceito negativista e estigmas que impedem analisar e compreender a situação vigente fora dos trâmites em que se está acostumado. $\mathrm{O}$ aperfeiçoamento da arte, da ciência, da razão e da filosofia não pode "caber se não a uma terra de tolerância e liberdade" (Hume, 2001, p. 22).

Não há dignidade humana respeitada, na luta pelo poder, quando os meios não são avaliados em função do respeito à vida, mas sim, da vontade de uns em detrimento de outros. Como afirma Corbisier (1978, p. 18) "o desenvolvimento, como o entendemos, é um processo global, que modifica, que transforma a própria estrutura, a essência mesma do país em que se verifica”. Não se trata de um processo que se limita ao aspecto econômico, mas sim uma transformação que pode afetar todos os setores da vida nacional, do econômico ao político e cultural.

A educação política, que liberta a mente como forma de criar possibilidades de desenvolvimento cultural e social, é concretizada mediante a formação dos seus cidadãos, segundo Tácito "numa época em que se pode pensar o que se quer e dizer o que se pensa" (In: Hume, 2001, p. 15), isto é, no tempo de paz e liberdade política, econômica, social e cultural. Enquanto se permanecer na política de dependência em relação às formas de pensamento e de desenvolvimento educacional, a educação que proporcionaria maior crítica terá menos relevância nos espaços políticos de domínio.

O problema dos direitos humanos que se constata em Angola nesse momento é a sua não-efetividade, pois, sua defesa depende da institucionalização de um sistema ou posição de poder na sociedade. Como se sabe, o objeto dos direitos econômicos e sociais são as políticas públicas ou programas de ação governamental que visam suprimir as carências sociais. Portanto, para haver cidadania democrática, 
garantia e responsabilidade política dos direitos humanos, pressupõe-se que todos devem ter condições e possibilidades de serem tratados de forma igual diante da lei, participação política e condições socioeconômicas básicas, pois como dizia Touraine (2003)

\begin{abstract}
só podemos viver juntos, isto é, combinar a unidade de uma sociedade com a diversidade das personalidades e das culturas, se colocarmos a idéia de sujeito pessoal no centro de nossa reflexão e de nossa ação. O sonho de submeter todos os indivíduos às mesmas leis universais da razão, da religião ou da história, sempre se transformou em pesadelo, em instrumento de dominação; a renúncia a todo princípio de unidade, a aceitação de diferenças sem limites, conduz à segregação ou à guerra civil (Touraine, 2003, p. 25).
\end{abstract}

Vivermos juntos requer aproximar o sujeito da combinação entre a identidade pessoal e a cultura particular com a participação num mundo racionalizado por este mesmo trabalho, de sua liberdade e responsabilidade.

Cada vez mais, aparece a idéia de que é necessário compreender que o desejo de uma "democracia, estabilidade e paz não podem conviver com condições de pobreza crônica, miséria e negligência". Uma insatisfação que provém da ausência de condições sociais pode criar "largas escalas de movimentos de pessoas, incluindo adicionais fluxos de refugiados e migrantes denominados 'refugiados econômicos', com todas as suas tragédias e problemas"

Se os direitos civis e políticos constituem, segundo Comparato (2004, p. 333), "um meio de defesa de indivíduos ou grupos sociais contra os privilégios privados e abuso de poder estatal", o pacto dos direitos econômicos, sociais e culturais devem ter como elemento primordial a "proteção das classes ou grupos sociais desfavorecidos contra a dominação socioeconômica exercida pela minoria poderosa". Trata-se da defesa contra a oligarquia política e a dominação de classe.

\footnotetext{
${ }^{75}$ Cf. Statement to the World Conference on Human Rights on Behalf of the Committee on Economic, Social and Cultural rights, UN Doc E/1993/33, Annex III. In: Piovesan (et al), 2003, p. 110. Lembra-se o caso de Angola que, de 1976 a 2002, esteve mergulhada numa guerra militar - a principio entre UNITA, MPLA e FNLA e, mais tarde, entre a UNITA e MPLA, sendo esta terminada após a morte do líder da UNITA (fevereiro de 2002). As conseqüências desta guerra manifestam-se através da miséria, desestruturação familiar, falta de moradia digna e de garantia dos direitos.
} 
Mesmo depois de passados mais de trinta anos de independência, a garantia do direito à educação e à convivência pacífica, parece-nos que ainda está aquém da situação que as guerras ${ }^{76}$ semearam na vida dos angolanos devido a uma imposição da "superioridade" hegemônica da ideologia dominante.

As violações constantes no campo dos direitos civis e políticos, que têm ocorrido em Angola, também se dão por "interferências abusivas do poder público na vida privada e no exercício dos direitos políticos", enquanto que, nos direitos econômicos, sociais e culturais, a "antijuridicidade consiste na inércia estatal, na negligência ou recusa dos órgãos públicos em limitar ou controlar o poder econômico privado" (Comparato, 2004, p. 333).

Em suma, abordar a garantia dos direitos sociais e em particular o direito à educação como desafio político consistiu uma tentativa de busca e compreensão da necessidade sobre a qual se fundamenta a defesa e exigências dos direitos da vida humana. Entendemos que a garantia da cidadania passa pela formação plena da dignidade humana sem preconceito, discriminação e exclusão.

\footnotetext{
76 São vários mecanismos, além da guerra e tortura, através dos quais se violam constantemente os direitos humanos. Como bem publicou a Agência de notícias - www.Angonoticias.com - no dia 12 de junho de 2005, "O reino Unido vendeu armas à África no valor de 1,5 bilhões de euros". O Jornal The Observer relata que, em 2004, a venda de armamentos pelo Reino Unido a países africanos alcançou o valor de 1,5 bilhões de euros. Um montante que corresponde à quadruplicação do registrado em 1999. A maior parte deste material bélico destina-se a países com grande índice de violações dos direitos humanos. Para Angola o Reino Unido vendeu o material por 45 milhões de euros e para a África do Sul por 166 milhões de euros. Este exemplo leva-nos a questionar a força ou poder que a ONU e outros organismos internacionais têm para impedir que casos como este se tornem viáveis. Os países ricos que possuem altas indústrias de material bélico são uma prova clara de violação dos direitos humanos e, como afirma a Organização não governamental britânica Saferworld, "se Londres quer realmente ajudar África, deveria reponderar a venda de armas a esses países" e, por outro lado, se houvesse realmente interesse (nos países com altas tecnologias de produção de material bélico), em promover a paz mundial e acabar com a fome nos países africanos, asiáticos e da América latina, em hipótese alguma poderiam, constantemente, incentivar a compra de armamentos sob uma ideologia de "defesa" nacional, que nada mais é que incentivar a guerra e propagação da miséria nos países chamados “Terceiro Mundo".
} 


\section{CONCLUSÃO}

Constituiu preocupação fundamental, neste trabalho, demonstrar por meio de dados, documentos e outras fontes bibliográficas, a situação educacional angolana, o percurso do processo de organização, as reformas e perspectivas na atualidade. Outra preocupação, que também nos acompanhou em todo trabalho, foi a de verificar se as justificativas construídas, durante a guerra civil, são suficientes hoje para explicar a situação em que o sistema educacional se encontra, em termos de atendimento - acesso ao ensino - e abrangência nacional, o de investimento na educação e de formação de professores. Percebemos que, para explicar a situação em que se encontra o sistema educacional, não podemos nos deter apenas no fator guerra (isoladamente), colonial ou de intervenção externa, mas também e, sobretudo, procurar antes compreender a responsabilidade político-social dos atores nacionais no momento em que efetivaram a guerra em Angola, estabelecendo as relações de luta política pelo poder.

Depois da guerra (2002) o aspecto que fundamenta e justifica as razões, pelas quais temos ainda que nos preocupar com a educação e formação da sociedade angolana, está ligado ao fato de os problemas sociais não ultrapassados anteriormente, estarem presentes, de forma mais alargada, no novo contexto político que se configurou a partir da implantação da política de economia de mercado. A garantia do direito à educação e a tomada de medidas sociais mais abrangentes para a implementação dos direitos humanos e condições básicas de saúde e educação ainda parecem estar longe de se tornarem realidade no atual contexto político.

Compreendemos que a conquista dos direitos fundamentais do homem ou a busca da qualidade de vida social e política passa, necessariamente, pela reformulação dos princípios políticos e filosóficos que norteiam o sistema educacional, o crescimento e desenvolvimento econômico. A educação permite às pessoas a possibilidade de terem clareza de suas ações e conhecimento necessário para a superação da "ignorância" construída pela política do silenciamento dos problemas sociopolíticos resultantes da guerra civil, da interdição (a não participação) e proibição da crítica social ou do poder instituído. 
Atualmente, entendemos que a qualidade de vida não consiste pura e simplesmente no ter, mas, sobretudo no ser, daí a necessidade fundamental de se humanizar as ações políticas, pois, é a partir destas que se efetiva a maior participação do homem nos assuntos públicos. É certo que o ser pleno requer uma dada satisfação material e imaterial, uma vivência com qualidade formal (conhecimento e desenvolvimento da ciência) e qualidade política (participação efetiva e realização concreta de mudanças para melhoria sociocultural). É este aspecto, da qualidade formal e política, negado a milhões de angolanos durante o período de guerra, que nos convém defender tendo como perspectiva uma possível mudança educacional, melhoria da formação dos professores, maior investimento em educação, saúde e pesquisa científica.

Uma das grandes injustiças sociais consiste no fato de o Estado negar ao seu povo as possibilidades de formação, exercício de liberdade intelectual e crítica que poderia possibilitar o desenvolvimento da vida cultural, maior coesão social e defesa dos direitos humanos. A negação das possibilidades que dependem de uma formação efetiva demonstra um aspecto de pobreza política, pois, a repressão da liberdade e a ausência da educação fazem com que, as pessoas destituídas destes direitos não se reconheçam injustamente pobres ou injustamente governados. Esta pobreza se traduz, segundo Ziegler (2002), em "fome de alimentos, fome de saber, fome de conhecimentos, de liberdade, de lazer", e nada poderia distinguir tanto os homens como a ausência das possibilidades de desenvolvimento do conhecimento, da crítica, liberdade e paz.

As pessoas permanecem na condição de pobreza porque são coibidas de reagir e mantidas como massa de manobra. Elas estão destituídas do direito de participarem na construção de uma nação mais justa e na defesa dos direitos fundamentais à vida pública. Levar o aluno a uma tomada de consciência crítica, em relação à sua sociedade e compreender sua condição social e política poderia ser uma das metas do trabalho educativo realizado pela instituição escolar. O despertar da crítica constitui uma forma e possibilidade da escola poder ir além do mero papel de reprodutor do sistema vigente (aparelho do Estado) e permitir ao aluno reelaborar sua visão e postura social em relação ao Estado.

Constituem aspectos fundamentais da vida sociocultural a ética na política, a redução da desigualdade social, o estado de direito, a equalização das oportunidades (econômicas, educacionais, de participação e de desenvolvimento) e a 
dignidade dos serviços públicos. A busca pela qualidade de vida, a que nos referimos, significa também criar possibilidades de reelaborar a própria história, de possuir uma postura política diferente de valorização da cultura angolana. A educação, o poder aquisitivo e a expectativa de vida constituem indicadores fundamentais que, segundo os estudos realizados pela ONU, requerem um certo equilíbrio para que haja qualidade de vida social. Se, por um lado, a expectativa de vida baseia-se, não apenas, no viver muito como também no viver bem, por outro lado, para que as pessoas tenham oportunidades na luta pela participação e desenvolvimento humano, as estruturas políticas e educacionais e de poder estabelecidas precisam contribuir para o propósito de emancipação. A educação representa o primeiro aspecto que abre as portas, ou seja, o ponto pelo qual começam as oportunidades para as demais situações atinentes à vida social, como a construção da cidadania, produção econômica e distribuição de renda.

O sistema educacional organizado e implementado em Angola a partir de 1976 foi fundamentalmente influenciado por um caráter político e "ideológico" que parte da visão de partido único, legitimando com isso, um certo poder e a negação do outro. Quando o sistema educacional está desvinculado de uma política de desenvolvimento cultural e qualidade de vida social, no âmbito geral do país, contribui mais para a implantação da "agressão" e legitimação da construção do privilégio, perdendo com isso a noção ética e cultural, para servir a uma ideologia no poder. Qualquer ideologia sem conhecimento reflexivo pode mais contribuir para inculcar a ignorância do que para uma crítica social propriamente dita, confundindo, por exemplo, competência com fidelidade ideológica. Urge então a necessidade de se discutir, rever e refazer o sentido histórico de vitória que trouxe o benefício para uns poucos em detrimento da maioria.

Trata-se de um compromisso constitutivo da "escola", chegar a uma educação de qualidade, na qual, todos podem, em condições iguais, formar-se como sujeitos históricos críticos e criativos. Por educação compromissada, política e socialmente, com a condição humana entendemos aquela que se preocupa com que a nova geração aprenda a pensar para melhor intervir e não apenas a fazer uso ou fazer funcionar o que já está pronto. Isto requer também dos professores formação e condições fundamentais que lhes permitam exercer o trabalho de ensino e pesquisa, autonomia para criar e recriar o projeto pedagógico; condições para refletir as diferentes 
práticas pedagógicas, beneficiando-se da inovação constante que a tecnologia dispõe; e, finalmente condições de manejo dos instrumentos proporcionados pela tecnologia.

As condições aqui apontadas são importantes à vida do professor, e reunidas estas condições espera-se mais responsabilidade na atividade de ensino e pesquisa para aumentar o entendimento das questões concretas (acesso ao ensino de qualidade, condições administrativas de bens públicos, a garantia dos direitos humanos e dos trabalhadores e responsabilidade cultural) de cada província. A escola pode contribuir, por meio da análise e compreensão destas questões e, mediante o processo de ensino e pesquisa, pode apontar as possíveis saídas.

Entendemos que o papel primeiro do professor é despertar o interesse vital do aluno pela reflexão e pesquisa em qualquer estágio ou nível de formação. Segundo Bachelard, deve buscar-se no ensino, "psicanalisar o interesse, derrubar qualquer utilitarismo por mais disfarçado que seja, por mais elevado que se julgue, voltar o espírito do real para o artificial, do natural para o humano, da representação para a abstração". Com isto pretende-se "tornar claramente consciente e ativo o prazer da estimulação espiritual na descoberta da verdade" (Bachelard, 2005, p. 13). A atividade de professor requer condições de formação e capacidade de domínio do conhecimento (pesquisa), pois sem conhecimento ele fica destituído de seu poder de ensino que só se dá pelo conhecimento e domínio daquilo que ele vai ensinar.

O contexto histórico que o país viveu contribuiu, em grande parte, para que a maioria dos alunos deixasse de ser candidata ao pensar, limitando-a ao saber fazer técnico ou pura e simplesmente fazer uso daquilo que já foi produzido por países tidos como mais desenvolvidos, portanto, limitada à condição de consumidora. Faz-se necessário à cada geração de Angola desenvolver a crítica e o desejo pelo saber tanto em relação ao já conhecido quanto ao desconhecido (política e historicamente), com uma mente sempre alerta diante dos conhecimentos habituais que, às vezes, não permitem sair dos espaços feitos e fechados, e das chamadas "verdades escolares", para desenvolver-se o espírito científico que, como se sabe, sempre contradiz a experiência comum ou, mais concretamente, o chamado conhecimento do senso comum que, raramente, está assente sobre uma base sustentável.

A dificuldade de acesso a informações ou conhecimento, constatado no país, requer uma resposta por via do domínio e construção de uma "nova" cultura do conhecimento - entendida aqui como a liberdade de desenvolvimento e esclarecimento 
da verdade sobre os fatos históricos, políticos, sociais e culturais, e como a valorização do papel do intelectual e sua produção na sociedade angolana -, visando com isso, superar os obstáculos ideológico-partidários vigentes. Esta construção poderia dar-se na luta pela superação do "conhecimento" anterior, que se julgue mal estabelecido, ultrapassar o que é obstáculo à construção da democracia, paz e convivência sociopolítica. Outra dificuldade provém do fato daqueles a quem se dirige o ensino (geração nova) não estarem desligados (livres), totalmente, do saber ideológico já construído por esta sociedade (geração adulta). Aliás, como afirma Bachelard (2005, p. 18), os que se apresentam à escola já são bem velhos porque têm a idade de seus preconceitos e "aceder à ciência é rejuvenescer espiritualmente, é aceitar uma brusca mutação que contradiz o passado", dando possibilidades para uma verdadeira mudança e revolução cultural.

É a possibilidade de mudança que precisa ser criada pela educação, e é importante tê-la em consideração nas reformas educacionais de Angola depois da guerra (2002). Para tal, o professor precisa ter em conta, nas atividades escolares de ensino, que o aluno traz para a escola conhecimentos empíricos já construídos e prontos e, desta forma, o trabalho do professor consiste, não em fazer com que o aluno se limite, segundo Bachelard (2005, p. 23), a essa cultura experimental, que já traz consigo de uma forma sedimentada, mas em possibilitar que este aluno derrube "os obstáculos já sedimentados pela vida" quotidiana, para possibilitar a crítica. Portanto, "admitindo até que uma cabeça bem feita escape ao narcisismo intelectual tão freqüente na cultura literária e na adesão apaixonada aos juízos do gosto, pode-se com clareza dizer que uma cabeça bem feita é infelizmente uma cabeça fechada" (Bachelard, 2005, p. 20). E as crises de crescimento e desenvolvimento do pensamento requerem, necessariamente, uma reorganização total do sistema de conhecimento (saber).

É preciso uma educação capaz de romper com determinadas estruturas sociais que estão "naturalizadas" na mente dos angolanos. Sabemos que é complexo falar dos danos que uma guerra pode provocar numa pessoa, mas, vendo as narrativas de sobreviventes da guerra angolana, é possível perceber que, entre o que é dito pelo discurso da classe dominante e o que é realizado, existe um espaço vazio camuflado sob o discurso ideológico de defesa e permanência no poder, não obstante o término da guerra. Contudo, as relações complexas que se dão no país angolano levam-nos a pensar que, apesar de toda a situação, ainda é possível pensar-se um sistema de ensino eficaz, 
baseado na justiça social e na garantia dos direitos humanos. Sendo assim verdadeiro tal propósito, o engajamento educacional deve inserir-se no espaço da discussão política, espaço este que deve ser democrático para permitir maior participação, clareza e transparência na administração dos bens públicos e gestão dos recursos financeiros (de ensino).

A dificuldade de mudança resulta também da distância existente entre o que é apreendido e o que simplesmente é reproduzido sem crítica. A mudança ocorre à medida que se eleva o nível de compreensão e crítica, visando superar a simples reprodução, para isso, não pode haver limitação no ensino. Não haverá revolução cultural e um posicionamento, em termos de pensamento político, tecnológico e científico, se a sociedade estiver limitada ao ensino primário e a fazer uso (consumo) apenas do que vem de outros países. Para a sociedade poder arrogar-se do desenvolvimento do espírito científico e de sua cultura, necessita estar segura de si mesma e estar à altura de avançar além do que já conquistou, dar um passo significativo na vida política, econômica e no pensamento científico. Constatamos que é importante inserir o debate educacional no espaço da discussão política, justamente por constituir elemento fundamental, não como um dos aparelhos (escola) do Estado que através dele se tenta conformar ou moldar o comportamento das pessoas, mas sim, como elemento propiciador de uma visão e mentalidade diferentes daquelas até então edificadas.

Percebemos também, durante o trabalho, que a resposta das questões "a serviço de quem esteve e está o Estado e por que se torna cada vez mais difícil a materialização de uma (verdadeira) reforma e melhoria do ensino?" é, conforme demonstra a realidade angolana, a de que o Estado não está a serviço da sociedade e, mesmo em termos históricos, ainda parece complexo afirmar, por exemplo, que houve uma fase em que este esteve dedicado ao serviço à sociedade, a qual se propunha governar tal como apontam os discursos. Ele está a serviço da classe (detentora do capital econômico) que o dirige, em função desta, continuamente procurou (e procura), através de vários meios como a guerra, a fome, analfabetismo da maioria, autoritarismo, etc. manter e defender seu poder e legitimidade. Sabe-se, por exemplo, que a fome e a miséria de hoje não são pura e simplesmente problemas técnicos, nem tão pouco o analfabetismo e a limitação no ensino resultam, tão somente, dos problemas pedagógicos ou de metodologias de ensino. Tudo isso ocorre por que "privatizou-se" os bens públicos assim como o "Estado". 
O mesmo vale para as escolas chamadas públicas, mas que não o são no sentido político amplo, porque nem todos tiveram ou têm acesso a esse ensino e nem mesmo hoje podem, todos os que quiserem, conseguir espaço para estudar. Apesar de aumentarem algumas escolas particulares e, portanto, também propriedade privada, isso não significa que todos têm ou terão acesso ao ensino devido às condições econômicas que as particulares exigem. Diante desta situação, não nos parece errado afirmar que ainda hoje o sistema de ensino está longe de se tornar universal ou atender o maior número possível da população que dele necessita.

As políticas de campanhas contra a fome e desemprego, por exemplo, sempre fracassaram (e ainda fracassarão) porque a máquina do Estado (agora capitalista) precisa disto para se manter viva e, nesse caso, toda tentativa de melhoria encontrará várias barreiras ou paredes intransponíveis enquanto tudo estiver regido pela lógica do capital, do qual o Estado está a serviço. A economia de mercado, apesar de defender maior liberdade, na verdade, destina esta liberdade àqueles que possuem condições necessárias para a disputa no mercado, diferente de um pequeno agricultor (camponês) ou funcionário que vive de um salário ínfimo.

A educação é um fenômeno social e parte integrante das relações sociais, econômicas, políticas e culturais que a sociedade constrói. Isso permite perceber porque as finalidades e meios de educação se subordinam à organização e dinâmica das relações entre as classes sociais estabelecidas e legitimadas ao longo do tempo. Com isso, percebe-se que, mesmo no capitalismo incipiente de Angola, as relações sociais são fortemente marcadas pela divisão da sociedade em classes, em que capitalistas e trabalhadores ocupam lugares opostos no processo de produção, e o acesso à educação é diferenciado, na medida em que ela é determinada pelas condições econômicas.

A desigualdade entre os homens determina não apenas as condições materiais de vida e de trabalho dos indivíduos, mas também a diferença no acesso à cultura escolar, isto é, à educação "formal". Na sociedade regida pelas diferenças, baseadas, além de outros mecanismos, no saber escolar, os chamados analfabetos não são apenas aqueles que não têm domínio da escrita e da leitura, mas também aqueles que estão desprovidos do senso crítico e de compreensão da realidade nacional e mundial. Sendo assim, defender para a população um ensino apenas até a sexta classe é mais uma prova de contribuir para a continuidade e perpetuação do analfabetismo, isto é, da falta do senso crítico num mundo que exige da humanidade capacidade cada vez 
mais alta de compreensão e análise. Além de contribuir para manter os privilégios de uma determinada classe que se apropriou do poder, tal política também contribui para negar à maioria da população o direito de serem "livres", em termos de pensamento (liberdade intelectual) e posicionamento político, que requer conhecimento, para que decidam seus próprios destinos num mundo de tantos desafios.

Portanto, o analfabetismo hoje não consiste apenas na ausência do saber ler e escrever como também no fato de estar tolhido para uma ação consciente e construtiva, na falta de domínio dos meios de informação e tantos outros mecanismos que a própria humanidade desenvolveu até o presente momento. $\mathrm{O}$ que se pretende defender aqui é, certamente, uma educação, no sentido amplo, de um real aprendizado, de um esforço de compreensão crítica da realidade angolana. A educação como prática de liberdade construída e conquistada, prática que permite ao homem interagir politicamente na sociedade e no seu trabalho.

Está posto o desafio e a necessidade de mudança, uma vez que o que era apontado como "bem feito" não satisfaz às necessidades da atual conjuntura política e social que clama pela democracia, paz e justiça social. As verdades prontas precisam ser questionadas para criarem-se novos pilares de convivência social e desenvolvimento cultural. Isso requer, de alguma forma, refletir seriamente sobre os métodos ou procedimentos e finalidade (concepção de homem que se pretende formar, princípios filosóficos, etc.) sobre os quais deveremos traçar a educação angolana. 


\section{BIBLIOGRAFIA}

ABRANCHES, Henrique. Reflexões sobre cultura nacional. Lisboa. Edições 70, 1980.

ALTUNA, Raul Ruiz de Asúa. Cultura tradicional banto. Luanda. Secretariado Arquidiocesano de Pastoral, 1985.

ANDRADE, Mário Pinto. Origens do Nacionalismo Africano, Continuidade e Ruptura nos Movimentos Unitários Emergentes da Luta contra a Dominação Colonial Portuguesa: 1911-1961. Lisboa. Publicações Dom Quixote, 1997.

ANDRÉ, António Miguel. "Meninos de rua ou meninos de Estado: a educação nãoformal em Angola”. In: SIMSON, Olga R. de M. Von; PARK, Margareth B.; FERNANDES, Renata S. (Orgs). Educação não-formal: cenários da criação. Campinas, SP. Editora da UNICAMP/ Centro de Memória, 2001.

ANGOLA. Documentos do MPLA. $1^{\text {a }}$. Série no ${ }^{\circ}$. 2. Lisboa. ULMEIRO, 1977 (Terceiro Mundo e Revolução).

APPIAH, Kwame Anthony. Na casa de meu pai. Rio de Janeiro. Contraponto, 1997.

ARENDT, Hannah. Entre o passado e futuro. $5^{\text {a }}$. ed. São Paulo. Perspectivas, 2000 (Debates Política).

A condição humana. Tradução de Roberto Raposo. $10^{\mathrm{a}}$. ed. Rio de Janeiro. Forense Universitária, 2004.

Responsabilidade e julgamento. Tradução de Rosaura Eichenberg. São Paulo. Companhia das Letras, 2004.

AZAMBUJA, Darcy. Introdução à ciência política. 11 a . ed. São Paulo. Globo, 1998.

AZANHA, José Mário Pires. Educação: alguns escritos. São Paulo. Editora Nacional. 1987 (atualidades pedagógicas Vol. 135).

- Uma idéia de Pesquisa Educacional. São Paulo. Editora da Universidade de São Paulo, 1992.

AZEVEDO, Ávila de. Relance sobre a Educação em África. Coleção Estudos de ciências políticas e sociais. $\mathrm{n}^{\circ}$.69. Lisboa, 1963 (Fundamentos e perspectivas).

BACHELARD, Gaston. A formação do espírito científico: contribuição para uma psicanálise do conhecimento. $5^{\mathrm{a}}$. ed. Tradução de Estela dos Santos Abreu. Rio de Janeiro. Contraponto, 2005. 
BAUMAN, Zygmunt. Modernidade e Ambivalência. Tradução de Marcus Penchel. Rio de Janeiro. Jorge Zahar Editor, 1999.

BECK, Ulrich. $O$ que é globalização? Equívocos do globalismo: Respostas à globalização. Tradução de André Carone. São Paulo. Paz e Terra, 1999.

BERNARDO, João. "O proletariado como produtor e como produto". In: Revista de Economia Política. Vol. 5, nº 3, julho-setembro. Brasiliense, 1985.

Estado: A silenciosa Multiplicação do Poder. São Paulo. Escrituras Editoras, 1998.

BITTENCOURT, Marcelo. Dos jornais às Armas: Trajetórias da contestação angolana. Lisboa. Vega Editora, 1999.

BOURDIEU, Pierre. A escola conservadora: as desigualdades frente à escola e à cultura. Tradução de Aparecida J. Gouveia. In: Maria A. Nogueira e Afrânio Catani (Orgs). Escritos de Educação. $4^{\mathrm{a}}$. ed. Rio de janeiro. Petrópolis: Vozes, 2002 (Ciências sociais da educação).

BRUNO, Lúcia Emilia Nuevo Barreto. Estudos sobre Poder, Ideologia, Trabalho e Educação. São Paulo. Faculdade de Educação - Universidade de São Paulo, 2004 (Tese de livre docência).

BRUNO, Lúcia E.N.Barreto. "Educação, qualificação e desenvolvimento econômico". In: _(Org). Educação e trabalho no capitalismo contemporâneo. (leituras selecionadas). São Paulo. Atlas S.A., 1996.

CABRAL, Amílcar. Unidade e Luta I: A Arma da Teoria. 2a . ed. Lisboa. Seara Nova, 1978 (Obras escolhidas). Unidade e Luta II: A Prática Revolucionária. Lisboa. Seara Nova, 1977 (Obras Escolhidas).

CAPAMBA, Assis. "Não é preciso o pacto de nação". In: Angola. Revista figuras e Negócios. Luanda - Angola. Ano: 5 nº.44. Agosto de 2004.

CARDOSO, António Silva. Angola, anatomia de uma tragédia. $5^{\mathrm{a}}$. ed. Portugal. Rolo \& Filhos - Lda, 2001.

CARREIRA, Iko. O pensamento estratégico de Agostinho Neto: Contribuição histórica. Lisboa. Publicações Dom Quixote, 1996 (Caminhos da memória ${ }^{\circ}$. 12).

CASTRO, Moracir Werneck de. Dois caminhos da revolução africana. Rio de Janeiro. Instituto Brasileiro de Estudos Afro-Asiáticos, 1962. 
CENTRAL INTELIGENCE AGENCY. Mais uma vez a CIA. United States of America. Edições da Agencia de Imprensa Nóvosti, 1988.

CHACACHAMA, Frei Miguel Gabriel (et. al). Direitos humanos. Guia de Apoio a Cursos de formação. Luanda. Centro Cultural Mosaiko, 1999.

COALIZÃO PELO FIM DO USO DE CRIANÇAS-SOLDADOS. Relatório Global sobre Crianças-Soldados de 2001. Luanda. 12 de Junho de 2001.

CONJIMBI, Luís. Situação da educação em Angola: grandes centros urbanos. In: I ${ }^{\text {a }}$. SEMANA SOCIAL NACIONAL 99. Educação para uma cultura de paz. De 23 a 28 de Novembro de 1999. Luanda. CEAST - Conferência episcopal de Angola e São Tomé e Príncipe, 2000.

COMPARATO, Fábio Konder. A afirmação histórica dos direitos humanos. $3^{\mathrm{a}}$. ed. Revista e ampliada. São Paulo. Saraiva, 2004.

As garantias institucionais dos direitos humanos. Aula de encerramento de um curso de direitos humanos, promovida pela Procuradoria da República no Rio de Janeiro, em 26 e 27 de Julho de 2001.

CORBISIER, Roland. Filosofia, política e liberdade. $2^{\mathrm{a}}$. ed. Rio de Janeiro. Paz e Terra, 1978 (Coleção Pensamento Crítico, Vol. 27).

CORREIA, Pedro de Pezarat. Angola: do alvor a Lusaka. Lisboa. Hugin Editores - Lda, 1996.

DEACON, Roger e PARKER, Ben. "Educação como Sujeição e como Recusa". In: SILVA, Tomaz Tadeu da (Org). $O$ sujeito da Educação: estudos foucaultianos. $5^{\text {a }}$. ed. Petrópolis, Rio de Janeiro. Vozes, 2002 (Ciências da Educação).

DELORES, Jacques. Educação: um tesouro a descobrir. $6^{\text {a }}$. ed. São Paulo. Cortez: MEC: UNESCO, 2001.

DIÁRIO DA REPÚBLICA DE ANGOLA. I ${ }^{\mathrm{a}}$. Série $\mathrm{n}^{0}$. 65. Lei de bases do sistema de educação $n^{o}$. 13/01. Luanda, 2001.

DIÁRIO DA REPÚBLICA DE ANGOLA. Lei $n^{\circ}$. 1/03: Lei do Programa Econômico e Social do Governo para o período de 2003-2004. I ${ }^{\mathrm{a}}$. Série, $\mathrm{n}^{\mathrm{o}} .1$ - 07 de janeiro de 2003.

DIÁRIO DA REPÚBLICA DE ANGOLA. Lei $n^{\circ}$. 29/03: Lei do Orçamento Geral do Estado para 2004. I ${ }^{\mathrm{a}}$. Série $\mathrm{n}^{\mathrm{o}} .103$ - 30 de dezembro de 2003. 
DIÁRIO DA REPÚBLICA DE ANGOLA. Lei $n^{\circ}$. 17/05: Lei do Orçamento Geral do Estado para 2006. I I $^{\mathrm{a}}$ Série $\mathrm{n}^{\mathrm{o}} .156$ - 30 de dezembro de 2005.

DIAS, Gastão Souza. O ensino em Angola. Delegação do Governo de Angola à $1^{\text {a }}$. Exposição Colonial Portuguesa. Luanda. Imprensa Nacional, 1934.

DEPARTAMENTO DE EDUCAÇÃO POLÍTICO-IDEOLÓGICA DE PROPAGANDA. Discursos do camarada presidente António Agostinho Neto. Informação do Comité Central do MPLA-Partido do Trabalho. Edição trimestral. $n^{0}$. 2. Set./Out./Nov. de 1978.

DOCUMENTOS: Um futuro de esperança para as crianças de Angola: uma análise da situação da criança. Luanda; Angola. UNICEF, 1998.

DOCUMENTOS DA INDEPENDÊNCIA. Angola: proclamação da Independência da Republica popular de Angola; 11 de novembro de 1975. Luanda. Edição do Ministério da Informação. Imprensa Nacional de Angola, 1975.

DU BOIS, Willian Edward Burghardt. As almas da gente negra. Tradução de Heloisa Toller Gomes. Rio de Janeiro. Lacerda-Lda, 1999.

ESPIRÍTO SANTO, Francisca do. História recente da educação em Angola. In: I SEMANA SOCIAL NACIONAL 99. Educação para uma cultura de paz. De 23 a 28 de Novembro de 1999. Luanda. CEAST - Conferência episcopal de Angola e São Tomé, 2000.

FANON, Frantz. Os condenados da terra. Prefácio de Jean-Poul Sartre. Tradução de José Laurênio de Mello. Rio de Janeiro. Civilização brasileira, 1968. . Pele negra, máscaras brancas. Tradução de Alexandre Pomar. Porto, [s.d].

FACULDADE DE DIREITO. Direito, Democracia e cidadania: coletânea de legislação. Vol. I. Luanda-Angola (Coleção Faculdade de Direito da Universidade Agostinho Neto), [s.d].

FERNÁNDEZ, Patrícia; ELDER, James. MICS: Inquérito de Indicadores múltiplos; Avaliando a situação das crianças e das mulheres angolanas no inicio do milênio - Relatório Analítico. Luanda - Angola. INE; UNICEF, 2003.

FÓRUM MUNDIAL DE EDUCAÇÃO Quadro de acção de Dakar de educação para todos. Abril de 2000. In: MINISTÉRIO DA EDUCAÇÃO. Plano Nacional de educação para todos (2001-2015): Vol. 9. Luanda, 2004.

FOUCAULT, Michel. A ordem do discurso: aula inaugural no Collège de France, pronunciada em 2 de Dezembro de 1970. Tradução de Laura Fraga de 
Almeida Sampaio. 11 ${ }^{\mathrm{a}}$. ed. São Paulo. Edições Loyola, 2004 (Leituras Filosóficas).

. “O Sujeito do Poder". In: RABINOW, Paul e DREYFUS Hubert L. Michel Foucalt: uma trajetória filosófica. Para além do estruturalismo e da hermenêutica. Tradução de Vera Porto Carrero. São Paulo. Forense Universitária, 1995.

FREIRE, Paulo \& GUIMARÃES, Sérgio. A África ensinando a gente: Angola, GuinéBissau, São Tomé e Príncipe. São Paulo. Paz e Terra, 2003.

GAMBOA, Silvio Sánchez. "A globalização e os desafios da educação no limiar do novo século: um olhar desde a América Latina". In: LOMBARDI, José Claudinei (Org). Globalização, Pós-modernidade e Educação. Campinas, SP. HISTEDBR: Autores Associados, 2001. (História, Filosofia e Temas Transversais).

GÓMEZ, Miguel Buendía.A educação Moçambicana: A história de um processo: $1962-$ 1984. São Paulo. Faculdade de Educação - Universidade de São Paulo, 1993 (Tese de doutorado).

GOVERNO DE ANGOLA. Ministério do Planeamento - Sistema das Nações Unidas: Relatório MDG/ NEPAD objectivos do desenvolvimento do milênio. Luanda Angola, 2003.

GREMAUD, Amaury Patick [et al]. Manual de economia. Organizadores. Diva Benevides Pinho, Maria Antonio Sandoval de Vasconcellos. $4^{\mathrm{a}}$. ed. São Paulo. Saraiva, 2003.

GUERRA, Henrique Lopes. Angola: estrutura Econômica e Classes Sociais. Luanda. Livrangol, 1973.

GUERRA, João Paulo. Savimbi, vida e morte. $3^{\mathrm{a}}$. ed. Lisboa. Bertrand Editora, 2002.

HARE, Paul. A última grande oportunidade para a paz em Angola: o processo de paz visto por dentro. Tradução de Jorge Almeida e Pinho. Porto. Campo das Letras S.A., 1999.

HUMAN RIGHTS WATCH. O Continente Esquecido: Crianças-Soldados de Angola. Luanda. Vol. 15, n. 10 (a). Abril de 2003.

HUME, David. Investigação sobre o entendimento humano. Tradução de José Oscar de Almeida Martins. São Paulo. UNESP, 1999 (Biblioteca clássica). 
IMBAMBA, José Manuel. Uma nova cultura para mulheres e homens novos: um projecto filosófico para Angola do $3^{\circ}$. Milênio à luz da filosofia de Battista Mondin. Luanda. UCAN - Universidade Católica de Angola; Paulinas, 2003.

JAEGER, Werner. Paidéia: a formação do homem grego. Tradução de Artur M. Parreira. 4ª ed. São Paulo. Martins Fontes, 2003.

JORGE, Manuel. Para compreender Angola: da política à economia. Lisboa. Publicações Dom Quixote, 1998 (Caminhos da memória $n^{0}$. 18). " "Infelizmente, fizeram de Angola um país de feiticeiros" (entrevista). In: Revista. Figuras \& Negócios. Ano: 5 nº 45. Setembro de 2002.

KANT, Immanuel. (1724-1804). Sobre a pedagogia. Tradução de Francisco Cock Fontanella. Piracicaba. Editora Unimep, 1996.

KAJIBANGA, Victor. “Educação e Níveis de Ensino: O papel do Ensino Superior”. In: I $^{\text {a }}$ SEMANA SOCIAL NACIONAL 99. Educação para uma cultura de paz. De 23 a 28 de Novembro de 1999. Luanda. CEAST - Conferência episcopal de Angola e São Tomé, 2000.

KISSINGER, Henry. Memórias. Vol. 3. Anos de revolução. Tradução de Joubert de Oliveira Brízida. Rio de Janeiro. Editora UniverCidade; Topbooks, 2001.

LEFORT, Claude. A invenção democrática. São Paulo. Brasiliense, 1983.

LUKAMBA, André. A globalização e os conflitos no sul: o caso angolano. Roma, 2001.

MATEUS, Dalila Cabrita. A Luta pela Independência: A Formação das Elites Fundadoras da FRELIMO, MPLA, PAIGC. Lisboa. Editorial Inquérito, 1999.

MAZULA, Brazão. Educação, cultura e ideologia em Moçambique: 1975-1985 (em busca de fundamentos filosófico-antropológicos). São Paulo. Faculdade de Educação - Universidade de São Paulo, 1993 (Tese de doutorado).

MÉNDEZ, Emilio Garcia. “Origem, sentido e futuro dos direitos humanos: reflexões para uma nova agenda". In: SUR - Revista internacional de Direitos Humanos. Ano: $1 . n^{0} .1 .1^{\circ}$. Semestre - Edição em Português. Prol Editora Gráfica Ltda, 2004 .

MENEZES, Solival. Mamma Angola: sociedade e economia de um país nascente. Prefacio de Paul Singer. São Paulo. EDUSP; FAPESP, 2000. 
MINISTÉRIO DA EDUCAÇÃO. Curso de formação de professores: pedagogia. Direção de formação de quadros de ensino. República Popular de Angola. Luanda, 1979.

Consulta pública sobre o plano de Acção Nacional de Educação para todos: Estratégia Integrada para a Melhoria do Sistema de educação. Vol. 5. Luanda 21 a 24 de Abril de 2004.

- Consulta pública sobre o plano de Acção Nacional de Educação para todos: Cronograma e estratégia de implementação da lei de bases do sistema de educação. Vol. 6. Luanda 21 a 24 de Abril de 2004. . Plano Nacional de educação para todos (2001-2015):

Documento base - quadro conceitual da consulta. Vol.1. Angola, 2004.

MINISTÉRIO DA ASSISTÊNCIA E REINSERÇÃO SOCIAL. Programa de expansão e desenvolvimento da $1^{\text {a }}$. infância e educação pré-escolar - Universo - crianças 0 a 5 anos: Alternativa proposta - programa PIC/PEC. Luanda, 2004.

MINISTÉRIO DO PLANEAMENTO. Estratégia de Combate à Pobreza: Reiserção Social, Reabilitação e Reconstrução e Estabilização Econômica. Versão sumária. Direçcão de Estudos e Planeamento. Luanda, 24 de setembro de 2003 aprovado pelo Governo a 11 de Fevereiro de 2004.

MISSION DE LA ASAMBLEA MUNDIAL DE LA JUVENTUD. Angola. Bruselas, Bélgica. Septiembre, 1962.

MORAIS, Regis de. Educação contemporânea: olhares e cenários. Campinas, SP. Editora Alínea, 2003 (Coleção educação em debate).

MORAIS, Regis de. (Org.). Filosofia, Educação e Sociedade: Ensaios filosóficos. Campinas, SP. Papirus, 1989.

NATÁlia FALÉ, F. M. Da Costa. Guia político dos PALOP. Editorial Fragmento Lda. Fundação de relações internacionais, 1992.

NETO, Manuel Brito. História e educação em Angola: do colonialismo ao MPLA. Campinas. Faculdade de Educação - Universidade Estadual de Campinas, 2005 (Tese de doutorado).

NGOENHA, Severino Elias. Filosofia Africana: das independências às liberdades. Maputo - Moçambique. Edições Paulinas - África, 1993.

NKRUMAH, Kwame. A luta de classes em África. Lisboa - Portugal. Sá da Costa, 1976 (Cadernos livres). 
Neocolonialismo: último estágio do imperialismo. Rio de Janeiro. Civilização Brasileira, 1967.

ODALIA, Nilo. A liberdade como meta coletiva. In: Jaime Pinsky \& Carla Bassanezi Pinsky (Orgs). História da cidadania. São Paulo. Contexto, 2003.

PATRÍCIO, José Gonçalves Martins. Angola-EUA: os caminhos do bom-senso. Lisboa. Publicações Dom Quixote, 1998 (Caminhos da memória $\mathrm{n}^{\circ}$. 16).

PEPETELA. “Introdução”. In: BRITTAIN, Victoria. Morte da dignidade: a guerra civil em Angola. Tradução de Tânia Sofia Rocha. Lisboa - Portugal. Publicações Dom Quixote, 1999.

PETERSON, Pedro Domingos. O professor do ensino básico: perfil e formação. Portugal. Instituto PIAGET. 2003 (coleção Horizontes pedagógicos).

PIOVESAM, F.; GOTTI, A.P.; E MARTINS, J.S. "A proteção Internacional dos direitos Econômicos, Sociais e Culturais”. In: PIOVESAN, Flávia. Temas de Direitos humanos. $2^{\mathrm{a}}$. ed. Revista e ampliada. São Paulo. Max Limonad, 2003.

PIOVESAN, Flavia. "Direitos sociais, econômicos e culturais e direitos civis e políticos”. In: SUR - Revista internacional de Direitos Humanos. Ano: 1. nº 1. $1^{\circ}$. Semestre - Edição em Português: Prol Editora Gráfica Ltda, 2004.

REGO, Victor da Cunha \& MORAIS, João M. Tito de. Angola através dos textos. São Paulo. Felmam-Rego, 1962.

RELATÓRIO MDG/NEPAD. Ojectivos de desenvolvimento do milênio. Governo de Angola, Ministério do Planeamento, Sistema das Nações Unidas em Angola. Luanda, 2003.

REVISTA ANGOLA HOJE. A reconstrução de uma nação em paz. Ano: 2 no 7. Janeiro/Fevereiro de 2003.

REVISTA VISÃO. Angola com fome, entre minas. 28 de Janeiro de 1999.

REVISTA TRIBUNA DIPLOMÁTICA. 11 de Novembro: 26 Anos na história de Angola. Ano: 1. Novembro de 2001.

REVISTA TRIBUNA DIPLOMÁTICA. Angola: Acordo de cessar-fogo. Ano 2. Abril de 2002.

RITO DIAS, Frei Manuel. As 24 horas da bíblia (poemas). 1ª . ed. Lisboa - Portugal. Difusora bíblica, 1997. 
RUSSELL, Bertrand. Da Educação: especialmente na primeira infância. Tradução de Monteiro Lobato. $5^{\text {a }}$. ed. São Paulo. Companhia Editora Nacional, 1977 (Série Filosofia Vol. 6).

SANGO, André de Oliveira João. O modelo político Angolano: Perspectivas. São Paulo. Faculdade de Filosofia, Letras e Ciências Humanas - Universidade de São Paulo, 2002 (Tese de doutorado).

SANTANA, Yes. "Afrocomunismos: Etiópia, Angola, Moçambique”. In: Stéphane Courtois, Nicolas Werth, (et al). O livro Negro do Comunismo: crimes, terror e repressão. Trad. Caio Meira. $3^{\mathrm{a}}$. ed. Rio de Janeiro. Bertrand Brasil, 2001.

SEN, Amartya. Desenvolvimento como liberdade. Tradução de Laura Teixeira Motta. São Paulo. Cia das Letras, 2000.

SERRANO, Carlos. Angola: Nasce uma nação: Um estudo sobre a construção da Identidade Nacional. São Paulo. FFLCH/ USP, 1988 (tese de doutorado).

SILVA NETO, Teresa José Adelina da. Contribuições a história da educação e cultura de Angola: grupos nativos, colonização e independência. Campinas, SP. UNICAMP, 2005 (Tese de doutorado).

TATI, Raul. Crise africana e processo de democratização em África: pertinência e implicações ético-antropológicas. Leiria. Arte Gráficas LTDA, 1999.

TAVARES, Fernando Jorge Pina. Educação, cultura e ideologia em Cabo Verde: Um estudo sobre a exclusão da língua materna do sistema de ensino, no período pós-colonial. São Paulo. Faculdade de Educação - Universidade de São Paulo, 2004 (Tese de doutorado).

TEIXEIRA, Evilázio F. Borges. A educação do homem segundo Platão. $3^{\mathrm{a}}$. ed. São Paulo. Paulus, 2003.

TODOROV, Tzvetan. O homem desenraizado. Tradução de Christina Cabo. Rio de Janeiro / São Paulo. Record, 1999.

TOURAINE, Alain. Poderemos viver juntos? Iguais e diferentes. Tradução de Jaime A. Clasen e Ephrain F. Alves. 2a ${ }^{\mathrm{a}}$ ed. Rio de Janeiro. Petrópolis: Vozes, 2003.

UNESCO. L'Affirmation de l'identité culturelle et la formation de la conscience nationale dans l'Afrique contempornaine. Paris. Unesco, 1981.

ZIEGLER, Jean. A fome no mundo explicada a meu filho. Rio de Janeiro. Vozes: Petrópolis, 2002.

WADE, Abdoulaye. Un destin pour l'Afrique. Paris. Lês Afriques: Karthala, 1989. 


\section{ANEXOS}

\section{ANEXO 1: LEI DE BASE DO SISTEMA DE EDUCAÇÃO Nº 13/01 DE 31 DE DEZEMBRO - 2001}

Considerando a vontade de realizar a escolarização de todas as crianças em idade escolar, de reduzir o analfabetismo de jovens e adultos e de aumentar a eficácia do sistema educativo;

Considerando igualmente que as mudanças profundas no sistema sócio-económico, nomeadamente a transição da economia de orientação socialista para uma economia de mercado, sugerem uma readaptação do sistema educativo, com vista a responder as novas exigências da formação de recursos humanos, necessários ao progresso sócioeconómico da sociedade angolana;

Nestes termos, ao abrigo da alínea $b$ ) do Artigo 88 da Lei Constitucional, a Assembléia Nacional aprova a seguinte:

\section{CAPITULO I \\ Definição, Âmbito e Objectivos}

Artigo 1

(Definição)

1. A Educação constitui um processo que visa preparar o indivíduo para as exigências da vida política, económica e social do País e que se desenvolve na convivência humana, no circulo familiar, nas relações de trabalho, nas instituições de ensino e de investigação cietífico-técnica, nos órgãos de comunicação social, nas organizações comunitárias, nas organizações filantrópicas e religiosas e através de manifestações culturais e gimno-desportivas.

2. O Sistema de Educação é o conjunto de estruturas e modalidades, através das quais se realiza a educação, tendentes à formação harmoniosa e integral do indivíduo, com vista à construção de uma sociedade livre, democrática, de paz e progresso social.

\section{Artigo 2}

(Âmbito)

1. O Sistema de Educação assenta-se na Lei Constitucional, no Plano Nacional e nas experiências acumuladas e adquiridas a nível internacional. 
2. O Sistema de Educação desenvolve-se em todo o território nacional e a definição da sua política é da exclusiva competência do Estado, cabendo ao Ministério da Educação e Cultura a sua coordenação.

3. As iniciativas da Educação podem pertencer ao Poder Central e Local do Estado ou a outras pessoas singulares ou colectivas, públicas ou privadas, competindo ao Ministério da Educação e Cultura a definição das normas gerais, de educação, nomeadamente nos seus aspectos pedagógicos, técnicos, de apoio e fiscalização do seu cumprimento e aplicação.

4. O Estado Angolano pode, mediante processo e mecanismos a estabelecer, integrar no Sistema de Educação, os estabelecimentos escolares sediados nos países onde seja expressiva a comunidade angolana, respeitando o ordenamento jurídico do país hospedeiro.

Artigo 3

(Objectivos Gerais)

São objectivos gerais da Educação:

a) Desenvolver harmoniosamente as capacidades físicas, intelectuais, morais, cívicas, estéticas e laborais da jovem geração, de maneira continua e sistemática, e elevar o seu nível cientifico, técnico e tecnológico, a fim de contribuir para o desenvolvimento sócio-económico do País;

b) Formar um indivíduo capaz de compreender os problemas nacionais, regionais e internacionais de forma crítica e construtiva para a sua participação activa na vida social, a luz dos princípios democráticos;

c) Promover o desenvolvimento da consciência pessoal e social dos indivíduos em geral e da jovem geração em particular, o respeito pelos valores e símbolos nacionais, pela dignidade humana, pela tolerância e cultura de paz, a unidade nacional, a preservação do ambiente e a conseqüente melhoria da qualidade de vida;

d) Fomentar o respeito devido aos outros indivíduos e aos superiores interesses da Nação Angolana na promoção do direito à vida, à liberdade e à integridade pessoal;

e) Desenvolver o espírito de solidariedade entre os povos em atitude de respeito pela diferença de outrem, permitindo uma saudável integração no mundo.

\section{CAPITULO II \\ Princípios Gerais}

Artigo 4

(Integralidade) 
O Sistema de Educação é integral, pela correspondência entre os objectivos da formação e os de desenvolvimento do país e que se materializam através da unidade dos objectivos, conteúdos e métodos de formação, garantindo a articulação horizontal e vertical permanente dos Subsistemas, Níveis e Modalidades de Ensino.

\section{Artigo 5}

(Laicidade)

O Sistema de Educação é laico pela sua independência de qualquer religião.

Artigo 6

(Democraticidade)

A Educação tem carácter democrático pelo que, sem qualquer distinção, todos os cidadãos Angolanos têm iguais direitos no acesso e na frequiência aos diversos níveis de ensino e de participação na resolução dos seus problemas.

\section{Artigo 7}

(Gratuidade)

1. Entende-se por gratuidade, a isenção de qualquer pagamento pela inscrição, assistência às aulas e o material escolar.

2. Ensino Primário é gratuito, quer no Subsistema de Ensino Geral quer no Subsistema de Ensino de Adultos.

3. O pagamento da inscrição, da assistência às aulas, do material escolar e do apoio social nos restantes níveis de ensino, constituem encargos para os alunos, que podem recorrer, se reunirem as condições exigidas, á bolsa de estudos interna, cuja criação e regime devem ser regulados por diploma próprio.

\section{Artigo 8}

(Obrigatoriedade)

O Ensino Primário é obrigatório para todos os indivíduos quer freqüentem o Subsistema do Ensino Geral.

\section{Artigo 9 \\ (Língua)}

1. O ensino nas escolas é ministrado em língua portuguesa.

2. O Estado promove e assegura condições humanas, científico-técnicas, materiais e financeiras para a expansão e a generalização da utilização e do ensino de línguas nacionais.

3. Sem prejuízo do ${ }^{\circ} 1$ do presente artigo, particularmente no subsistema de Educação de Adultos, o ensino pode ser ministrado nas línguas nacionais. 


\title{
CAPÍTULO III \\ Organização do Sistema de Educação \\ SECÇÃO I \\ Estrutura do Sistema de Educação
}

\author{
Artigo 10 \\ (Estrutura)
}

1. A Educação realiza-se através de um Sistema Unificado, constituído pelos seguintes Subsistemas de Ensino.

> Subsistema de Educação Pré-Escolar;

Subsistema de Ensino Geral;

$>$ Subsistema de Ensino Técnico-Profissional;

$>$ Subsistema de Formação de Professores;

$>$ Subsistema de Educação de Adultos;

$>$ Subsistema de Ensino Superior;

2. O Sistema de Educação estrutura-se em três níveis:
a) Primário;
b) Secundário;
c) Superior.

3. No domínio da formação de quadros para vários sectores económicos e sociais do país, sob a responsabilidade dos Subsistemas do Ensino Técnico-Profissional e da Formação de Professores, a Formação Média Técnica e Normal, corresponde ao $2^{\circ}$ Ciclo do Ensino Secundário, com a duração de mais um ano dedicado a profissionalização, num determinado ramo com carácter terminal.

\section{SECÇÃO II \\ Subsistema de Educação Pré-Escolar \\ SUBSECÇÃO I \\ Definição, Objectivos, Estrutura, Coordenação \\ Administrativa e Pedagógica}

\section{Artigo 11 \\ (Definição)}

O Subsistema de Educação Pré-Escolar é a base da educação, cuidando da primeira infância, numa fase da vida em que se devem realizar acções de condicionamento e de desenvolvimento psicomotor. 
Artigo 12

(Objectivos)

São objectivos do Subsistema da Educação Pré-Escolar:

a) Promover o desenvolvimento intelectual, físico, moral, estético e efectivo da criança, garantindo-lhe um estado sadio por forma a facilitar a sua entrada no Subsistema de Ensino Geral;

b) Permitir uma melhor integração e participação de crianças através da observação e compreensão do meio natural, social e cultural que a rodeia;

c) Desenvolver as capacidades de expressão, de comunicação, de imaginação criadora e estimular a actividade lúcida da criança.

Artigo 13

(Estrutura)

1. A Educação Pré-Escolar estrutura-se em dois ciclos:

a) Creche;

b) Jardim Infantil.

2. A organização, estrutura e funcionamento destes Ciclos é objecto de regulamentação própria.

\section{SECÇÃO III \\ Subsistema de Ensino Geral \\ SUBSECÇÃO I \\ Definição, Objectivos e Estrutura}

Artigo 14

(Definição)

O Subsistema de Ensino Geral constitui o fundamento do Sistema de Educação para conferir uma formação integral, harmoniosa e uma base sólida e necessária a continuação dos estudos em Subsistemas subseqüentes.

\section{Artigo 15}

(Objectivos)

São objectivos gerais do Subsistema de Ensino Geral:

a) Cancelar a formação integral e homogénea que permita o desenvolvimento harmonioso das capacidades intelectuais, físicas, morais e cívicas; 
b) Desenvolver os conhecimentos e as capacidades que favoreçam a auto-formação para um saber-fazer eficazes que se adaptem as novas exigências;

c) Educar a juventude e outras camadas sociais de forma a adquirirem hábitos e atitudes necessários ao desenvolvimento da consciência nacional.

d) Promover na jovem geração e outras camadas sociais o amor ao trabalho e potenciá-las para uma actividade laboral, socialmente útil e capaz de melhorar as suas condições de vida.

\section{Artigo 16 \\ (Estrutura)}

O Subsistema de Ensino Geral estrutura-se em:

a) Ensino Primário;

b) Ensino Secundário.

\section{SUBSECÇÃO II \\ Definição e Objectivos do Ensino Primário}

Artigo 17

(Definição)

O Ensino Primário, unificado por 6 anos, constitui a base do Ensino Geral, tanto para a Educação Regular como para a Educação de Adultos e é o ponto de partida para os estudos a Nível Secundário.

\section{Artigo 18}

(Objectivos)

São objectivos específicos do ensino Primário:

a) Desenvolver e aperfeiçoar o domínio da comunicação e da expressão;

b) Aperfeiçoar hábitos e atitudes tendentes à socialização;

c) Proporcionar conhecimentos e capacidades de desenvolvimento das faculdades mentais;

d) Estimular espírito estético com vista ao desenvolvimento da criação artística;

e) Garantir a prática sistemática de educação física e de actividades gimnodesportivas para o aperfeiçoamento das habilidades psico-motoras. 


\title{
SUBSECÇÃO III \\ Definição e Objectivos do Ensino Secundário Geral
}

Artigo 19

(Definição)

O Ensino Secundário, tanto para a educação de jovens, quanto para a Educação de Adultos, como para Educação Especial, sucede ao Ensino Primário e compreende dois ciclos de três classes:

a) O Ensino Secundário do $1^{\circ}$ Ciclo que compreende as $7^{\mathrm{a}}, 8^{\mathrm{a}}$ e $9^{\mathrm{a}}$ Classes;

b) O Ensino Secundário do $2^{\circ}$ Ciclo, organizado em áreas de conhecimentos de acordo com a natureza dos cursos superiores a que dá acesso e que compreende as $10^{\mathrm{a}}, 11^{\mathrm{a}}$ e $12^{\mathrm{a}}$ Classes.

Artigo 20

(Objectivos)

1. São objectivos específicos do $1^{\circ}$ Ciclo:

a) Consolidar, aprofundar e ampliar os conhecimentos e reforçar as capacidades, os hábitos as atitudes e as habilidades no Ensino Primário;

b) Permitir a aquisição de conhecimentos necessários ao prosseguimento dos estudos em níveis de ensino e áreas subsequentes;

2. São objectivos específicos do $2^{\circ}$ Ciclo:

a) Preparar o ingresso no mercado de trabalho e/ ou no Subsistema de Ensino Superior;

b) Desenvolver o pensamento lógico e abstracto e a capacidade de avaliar a aplicação de modelos científicos na resolução de problemas da vida prática.

\section{SECÇÃO IV \\ Subsistema de Ensino Técnico-Profissional \\ SUBSECÇÃO I \\ Definição, Objectivos e Estrutura}

\author{
Artigo 21 \\ (Definição)
}

O Subsistema de Ensino Técnico-Profissional é a base da preparação técnica e profissional dos jovens e trabalhadores começando, para o efeito, após o Ensino Primário. 
Artigo 22

(Objectivos)

É objectivo fundamental do Subsistema de Ensino Técnico-Profissional a formação técnica e profissional dos jovens em idade escolar candidatos a emprego e trabalhadores, preparando-os para o exercício de uma profissão ou especialidade, por forma a responder às necessidades do País e a evolução tecnológica.

Artigo 23

(Estrutura)

O Subsistema de Ensino Técnico-Profissional compreende:

c) Formação Profissional Básica;

d) Formação Média Técnica.

\section{SUBSECÇÃO II Formação Profissional Básica}

Artigo 24

(Definição)

1. A Formação Profissional Básica é o processo através da qual jovens e adultos adquirem e desenvolvem conhecimentos gerais e técnicos, atitudes, e práticas relacionadas directamente com o exercício duma profissão.

2. A Formação Profissional Básica visa a melhor integração do indivíduo na vida activa, podendo contemplar vários níveis e desenvolver-se por diferentes modalidades e eventualmente complementar a formação escolar no quadro da educação permanente.

3. A Formação Profissional Básica realiza-se após a $6^{\mathrm{a}}$ Classe, nos Centros de Formação Profissional públicos e privados.

4. A Formação Básica rege-se por diploma próprio.

\section{SUBSECÇÃO III Formação Média Técnica}

Artigo 25

(Definição e Objectivos)

1. A Formação Média Técnica consiste na formação técnico-profiisional dos jovens e trabalhadores e visa proporcionar aos alunos conhecimentos gerais e técnicos para os diferentes ramos de actividades económica e social do país, permitindo-lhes a inserção na vida laboral e, mediante critérios, o acesso ao Ensino Superior. 
2. A Formação Média Técnica realiza-se após a $9^{a}$ Classe com a duração de quatro anos em Escolas Técnicas.

3. Pode-se organizar formas intermédias de formação técnico-profissional após a $12^{\mathrm{a}}$ Classe do Ensino Geral com a duração de um a dois anos de acordo com a especialidade.

\section{SECÇÃO V \\ Subsistema de Formação de Professores \\ SUBSECÇÃO I \\ Definição, Objectivos e Estruturas}

Artigo 26

(Definição)

1. Subsistema de Formação de Professores consiste em formar docentes para a Educação Pré-Escolar e para o Ensino Geral, nomeadamente a Educação Regular, a Educação de Adultos e a Educação Especial.

2. Este Subsistema realiza-se após a $9^{\text {a }}$ Classe com duração de quatro anos em Escolas Normais e após estes, em Escolas e Institutos Superiores de Ciências de Educação.

3. Pode-se organizar formas intermédias de Formação de Professores após a $9^{\mathrm{a}}$ e a $12^{\mathrm{a}}$ Classes com a duração de um a dois anos, de acordo com a especialidade.

\section{Artigo 27}

(Objectivos)

São Objectivos do Subsistema de Formação de Professores:

a) Formar professores com o perfil necessário à materialização integral dos objectivos gerais da educação;

b) Formar professores com sólidos conhecimentos cientifico-técnicos e uma profunda consciência patriótica de modo a que assumam com responsabilidade a tarefa de educar as novas gerações;

c) Desenvolver acções de permanente actualização e aperfeiçoamento dos agentes de educação.

\section{Artigo 28 \\ (Estrutura)}

O Subsistema de Formação Profissional estrutura-se em:

a) Formação Média Normal, realizada em Escolas Normais; 
b) Ensino Superior Pedagógico realizado nos Institutos e Escolas Superiores de Ciências de Educação.

\section{SUBSECÇÃO II \\ Formação Média Normal}

Artigo 29

(Definição)

A Formação Média Normal destina-se à formação de professores de nível médio que possuam à entrada a $9^{a}$ Classe do Ensino Geral ou equivalente e capacitando-os a exercer actividades na Educação Pré-Escolar e ministrar aulas no Ensino Primário, nomeadamente a Educação Regular, a Educação de Adultos e a Educação Especial.

\section{SUBSECÇÃO III \\ Ensino Superior Pedagógico}

Artigo 30

(Definição)

1. O Ensino Superior Pedagógico destina-se à formação de professores de nível superior, habilitados para exercerem as suas funções, fundamentalmente no Ensino Secundário e eventualmente, na Educação Pré-Escolar e na Educação Especial.

2. Este Ensino destina-se à Agregação Pedagógica para professores dos diferentes Subsistemas e níveis de ensino, provenientes de instituições não vocacionadas para a docência.

\section{SECÇÃO VI \\ Subsistema de Educação de Adultos \\ SUBSECÇÃO I \\ Definição, Objectivos e Estrutura}

Artigo 31

(Definição)

1. O Subsistema de Educação de Adultos constitui um conjunto integrado e diversificado de processos educativos baseados nos princípios, métodos e tarefas da Andragogia e realiza-se na modalidade de Ensino Directo e /ou Indirecto.

2. O Subsistema de Educação de Adultos visa a recuperação do atraso escolar mediante processos e métodos educativos intensivos e não intensivos, estrutura-se em classes e realiza-se em escolas oficiais, particulares, de parceria, nas escolas polivalentes, em unidades militares, em centros de trabalho e em cooperativas ou associações agro-silvo- 
pastoris, destinando-se a integração sócio- educativa e económica do indivíduo a partir dos 15 anos de idade.

\section{Artigo 32}

(Objectivos específicos)

São Objectivos Específicos do Subsistema de Educação de Adultos:

a) Aumentar o nível de conhecimentos gerais mediante a eliminação do analfabetismo juvenil e adulto, literal e funcional;

b) Permitir a cada indivíduo aumentar os seus conhecimentos e desenvolver as suas potencialidades, nas duplas perspectiva de desenvolvimento integral do homem e da sua participação activa no desenvolvimento social, económico e cultural, desenvolvendo a capacidade para o trabalho através de uma preparação adequada às exigências da vida activa;

c) Assegurar o acesso da população adulta à educação, possibilitando-lhes a aquisição de competências tecno-profissionais para o crescimento económico e o progresso social do meio que a rodeia, reduzindo as disparidades exigentes em matéria de educação entre a população rural e a urbana numa perspectiva do género;

d) Contribuir para a preservação e desenvolvimento da cultura nacional, a protecção ambiental, a consolidação da paz, a reconciliação nacional, a educação cívica, cultivar o espírito de tolerância e respeito pelas liberdades fundamentais;

e) Transformar a Educação de Adultos num pólo de atracção e de desenvolvimento comunitário e rural integrados, como factor de actividades sócio-económica e para a criatividade do indivíduo.

\section{Artigo 33}

(Estrutura)

1- O Subsistema da Educação de Adultos Estrutura-se em:

a) Ensino Primário que compreende a Alfabetização e a Pós-Alfabetização;

b) Ensino Secundário que compreende os $1^{\circ}$ e $2^{\circ}$ Ciclos.

2- Os $1^{\circ}$ e $2^{\circ}$ Ciclos do Ensino Secundário organizam-se nos moldes previstos nos números 1 e 2 , respectivamente, do artigo $20^{\circ}$ da presente Lei.

3- O Subsistema de Educação de Adultos tem uma organização programática, de conteúdos e de metodologias de educação e de avaliação, bem como duração adequada às características, necessidades e aspirações dos adultos.

Artigo 34

(Regulamentação) 
O Subsistema de Educação de Adultos obedece a critérios a serem estabelecidos por regulamentação própria.

\title{
Secção VII \\ Subsistema do Ensino Superior \\ Subsecção I \\ Definição, Objectivos e Estrutura
}

\author{
Artigo 35 \\ (Definição)
}

O Subsistema do Ensino Superior visa a formação de quadros de alto nível para os diferentes ramos de actividade económica e social do país, assegurando-lhes uma sólida preparação científica, técnica, cultural e humana.

\section{Artigo 36 \\ (Objectivos)}

São objectivos do Subsistema do Ensino Superior:

a) Preparar os quadros de nível superior com formação científico-técnica, cultural num ramo ou especialidade correspondente a uma determinada área do conhecimento;

b) Realizar a formação em estrita ligação com a investigação científica, orientada para a solução dos problemas postos em cada momento pelo desenvolvimento do país e inserida no processo dos progressos da ciência, da técnica e da tecnologia;

c) Preparar e assegurar o exercício da reflexão crítica e da participação na produção;

d) Realizar cursos de Pós-Graduação ou especialização para a superação científicotécnica dos quadros do nível superior em exercício nos distintos ramos e sectores da sociedade;

e) Promover a pesquisa e a divulgação dos seus resultados para o enriquecimento e o desenvolvimento multifacêtico do país.

\section{Artigo 37 \\ (Estrutura)}

O Subsistema de Ensino Superior estrutura-se em:

a) Graduação;

b) Pós-Graduação. 
Artigo 38

(Graduação)

1. A Graduação estrutura-se em:

a) Bacharelato;

b) Licenciatura.

2. O Bacharelato corresponde a cursos de ciclo curto, com a duração de três anos e tem por objectivo permitir ao estudante a aquisição de conhecimentos científicos fundamentais para o exercício de uma actividade prática no domínio profissional respectivo, em área a determinar, com carácter terminal.

3. A Licenciatura, corresponde a cursos de ciclo longo, com a duração de quatro a seis anos e tem como objectivo a aquisição de conhecimentos, habilidades e práticas fundamentais dentro do ramo do conhecimento respectivo e a subsequente formação profissional ou académica específica.

Artigo 39

(Pós-graduação)

1. A Pós- Graduação tem duas categorias:

a) Pós-Graduação académica;

b) Pós-Graduação profissional.

2. A Pós-Graduação académica tem dois níveis:

a) Mestrado;

b) Doutoramento.

3. A Pós-Graduação profissional compreende a especialização.

4. O Mestrado, com a duração de dois a três anos, tem como objectivo essencial o enriquecimento da competência técnico-profissional dos licenciados.

5. A especialização corresponde a cursos de duração mínima de 1 ano e tem por objectivo o aperfeiçoamento técnico-profissional do licenciado.

6. O Doutoramento, com a duração de quatro a cinco anos, visa proporcionar formação científica, tecnológica ou humanista, ampla e profunda aos candidatos diplomados em curso de Licenciatura e/ou Mestrado. 
Artigo 40

(Tipo de Instituições de Ensino)

As Instituições de Ensino classificam-se nas seguintes categorias:

a) Universidades;

b) Academias;

c) Institutos Superiores;

d) Escolas Superiores.

\section{Artigo 41 \\ (Investigação Científica)}

1. O Estado fomenta e apóia as iniciativas a colaboração entre entidades públicas e privadas no sentido de estimular o desenvolvimento da ciência, da técnica e da tecnologia.

2. O Estado deve criar condições para a promoção de investigação científica e para a realização de actividades de investigação no ensino superior e nas outras instituições vocacionadas para o efeito.

Artigo 42

(Regulamentação)

O Subsistema de Ensino Superior rege-se por diploma próprio.

\section{Secção VIII \\ Modalidades de Ensino \\ Subsecção I \\ A Educação Especial}

Artigo 43

(Definição)

A Educação Especial é uma modalidade de ensino transversal, quer para o Subsistema do Ensino Geral, como para o Subsistema da Educação de Adultos, destinada aos indivíduos com necessidades educativas especiais, nomeadamente deficientes motores, sensoriais, mentais, com transtornos de conduta e trata da prevenção, da recuperação e da integração sócio-educativa e sócio-económica dos mesmos e dos alunos superdotados.

\section{Artigo 44}

(Objectivos Específicos)

Para além dos objectivos do Subsistema do Ensino Geral, são objectivos específicos da Educação Especial: 
a) Desenvolver as potencialidades físicas e intelectuais reduzindo as limitações provocadas pelas deficiências;

b) Apoiar a inserção familiar, escolar e social de crianças e jovens deficientes, ajudando na aquisição de estabilidade emocional;

c) Desenvolver as possibilidades de comunicação;

d) Desenvolver a autonomia de comportamento a todos os níveis em que esta se possa processar;

e) Proporcionar uma adequada formação pré-profissional e profissional visando a integração na vida activa;

f) Criar condições para o atendimento dos alunos superdotados.

Artigo 45

(Organização)

A Educação Especial é ministrada em instituições do Ensino Geral, da Educação de Adultos ou em instituições especificas de outros sectores da vida nacional cabendo, neste último caso, ao Ministério da Educação e Cultura a orientação pedagógica, andragógica e metodológica.

\section{Artigo 46 \\ (Condições Educativas)}

Os recursos educativos para a Educação Especial estão sujeitos às peculiaridades e características científico-técnicas desta modalidade de ensino e adaptadas às características da população alvo.

Artigo 47

(Regulamentação)

A Educação Especial rege-se por diploma próprio.

\section{Subsecção II \\ Educação Extra-Escolar}

Artigo 48

(Organização)

As actividades Extra-Escolares são realizadas pelos Órgãos Centrais e Locais da Administração do Estado e empresas em colaboração com as organizações sociais e de utilidade pública, cabendo ao Ministério da Educação e Cultura o papel reitor.

Artigo 49

(Objectivos) 
1. A Educação Extra-Escolar realiza-se no período inverso ao das aulas e tem como objectivo permitir ao aluno o aumento dos seus conhecimentos e o desenvolvimento harmonioso das suas potencialidades, em complemento da sua formação escolar.

2. A Educação Extra-Escolar realiza-se através de actividades de formação vocacional, de orientação escolar e profissional, da utilização racional dos tempos livres, da actividade recreativa e do desporto escolar.

Artigo 50

(Regulamentação)

A Educação Extra-Escolar rege-se por diploma próprio.

\title{
Capítulo IV
}

Regime de Frequência e Transição

\author{
Artigo 51 \\ (Educação Pré-Escolar)
}

1. À Educação Pré-Escolar têm acesso as crianças cuja idade vai até aos seis anos.

2. As crianças que até aos 5 anos de idade não tenham beneficiado de qualquer alternativa educativa dirigida à infância, devem frequentar a Classe de Iniciação.

\section{Artigo 52}

(Ensino Geral, Educação de Adultos e Formação Média Técnica e Normal)

Os regimes gerais de frequência e transição no Ensino Geral, na Educação de Adultos, na Formação Média Técnica e Normal pelas suas peculiaridades e características da população alvo são objecto de regulamentação própria.

\section{Artigo 53}

(Ensino Superior)

1.Têm acesso ao Ensino Superior os candidatos que concluam com aproveitamento o Ensino Médio geral, técnico ou normal, ou o equivalente e façam prova de capacidade para a sua frequência, de acordo com os critérios a estabelecer.

2.Os regimes gerais de frequência e transição no Ensino Superior são objecto de regulamentação própria.

\section{CAPÍTULO V \\ Recursos Humano-Materiais}

Artigo 54

(Agentes de Educação) 
1. É assegurado aos Agentes de Educação o direito á formação permanente através dos mecanismos próprios com vista à elevação do seu nível profissional, cultural e científico.

2. Os Agentes de Educação são remunerados e posicionados na sua carreira de acordo com as suas habilitações literárias e profissionais e atitudes perante o trabalho.

3. A progressão na carreira docente e administrativa está ligada à avaliação de toda a actividade de desenvolvimento no âmbito da educação, bem como ás qualificações profissionais e científicas.

4. Para efeitos do presente artigo, entende-se por Agentes de Educação os Professores, Directores, Inspectores, Administradores e outros gestores de educação.

\section{Artigo 55}

(Rede Escolar)

1. É da competência do Estado a elaboração da Carta Escolar, orientação e o controlo das obras escolares.

2. A rede escolar deve ser organizada de modo a que em cada região se garanta a maior diversidade possível de cursos, tendo em conta os interesses locais ou regionais.

3. É da responsabilidade dos Órgãos do Poder Local de Administração do Estado e da Sociedade Civil, o equipamento, a conservação, a manutenção e a reparação das instituições escolares de todos os níveis de Ensino até ao $1^{\circ}$ Ciclo do Ensino Secundário.

4. Os Órgãos do Poder Local da Administração do Estado devem proteger as instituições escolares e tomar as medidas tendentes a evitar todas as formas de degradação do seu património.

\section{Artigo 56}

(Recursos Educativos)

1. Constituem recursos educativos todos os meios utilizados que contribuem para o desenvolvimento do Sistema de Educação.

2. São recursos educativos:

a) Guias e Programas Pedagógicos;

b) Manuais Escolares;

c) Bibliotecas Escolares;

d) Equipamentos, Laboratórios, Oficinas, Instalações e Material Desportivo. 
1. O exercício da educação constitui uma das prioridades do Plano Nacional de Desenvolvimento Económico-Social e do Orçamento Geral do Estado.

2. As verbas e outras receitas destinadas ao Ministério da Educação e Cultura devem ser distribuídas em função das prioridades estratégicas do desenvolvimento do Sistema de Educação.

3. O Ensino promovido por iniciativa privada é financiado através da remuneração pelos serviços prestados ou por outras fontes.

4. O Estado pode co-financiar instituições educativas de iniciativa privada em regime de parceria desde que sejam de interesse público relevante ou estratégico.

\section{CAPÍTULO VI \\ Administração e Gestão do Sistema de Educação}

Artigo 58

(Níveis de Administração)

1. A delimitação e articulação de competência entre os diferentes níveis de administração e gestão do Sistema de Educação é objecto de regulamentação especial.

2. Cabe, designadamente, aos Órgãos da Administração Central do Estado:

a) Conceber, definir, dirigir, coordenar, controlar e avaliar o Sistema de Educação;

b) Planificar e dirigir normativa e metodologicamente a actividade da investigação pedagógica.

Artigo 59

(Posição e Organização das Escolas e Outras Instituições para a Educação)

1. As escolas e demais instituições de educação são unidades de base do Sistema de Educação.

2. As escolas e demais instituições de educação organizam-se de acordo com o Subsistema de Ensino em que estiverem inseridas.

3. Independentemente da sua especificidade e deveres particulares, as escolas e demais instituições de educação, organizam-se de molde a que, com a vida interna, as relações, o conteúdo, a forma e os métodos de trabalho, contribuam para a realização dos objectivos da educação.

4. As escolas e demais instituições de educação devem:

a) Aplicar e desenvolver formas e métodos de trabalho educativo e produtivo que se fundamentam na ligação do ensino com a aplicação prática dos conhecimentos adquiridos; 
b) Realizar a difusão e o enriquecimento do trabalho educativo utilizando várias formas de actividades livres dos alunos e estudantes.

5. As escolas e demais instituições de educação devem prestar uma atenção especial às condições e à organização, tanto da formação geral, como da formação profissional ou profissionalizante, nas oficinas, nos centros ou estabelecimentos escolares do país.

7. As normas gerais para a vida interna e o trabalho das escolas e demais instituições são regulamentados pelos respectivos Estatutos de Ensino e Regulamentos Gerais Internos.

\section{Artigo 60 \\ (Planos e Programas)}

Os Planos de Estudos e Programas de Ensino têm um carácter nacional e de cumprimento obrigatório, sendo aprovados pelo Ministro da Educação e Cultura.

\section{Artigo 61 \\ (Manuais Escolares)}

Os Manuais Escolares aprovados e adoptados pelo Ministério da Educação e Cultura são de utilização obrigatória em todo o território nacional e nos Subsistemas de Ensino para que forem indicados.

Artigo 62

(Calendário Escolar)

1. O ano escolar delimita o ano lectivo, tem carácter nacional e é de cumprimento obrigatório.

2. A determinação do ano escolar compete ao Conselho de Ministros, enquanto que a definição do ano lectivo é da competência do Ministro da Educação e Cultura.

Artigo 63

(Avaliação)

O Sistema de Educação é objecto de avaliação contínua com incidência especial sobre o desenvolvimento, a regulamentação e a aplicação da presente lei, tendo em conta os aspectos educativos, pedagógicos, psicológicos, sociológicos, organizacionais, económicos e financeiros.

\section{Artigo 64}

(Investigação em Educação)

1. A investigação científica em educação destina-se a avaliar e a interpretar científica, quantitativa e qualitativamente a actividade desenvolvida no Sistema de Educação por forma a corrigir os desvios, visando o seu permanente aperfeiçoamento. 
2. A investigação científica em educação é feita nas instituições vocacionadas ou adoptadas para o efeito.

3. A investigação científica em educação rege-se pôr diploma próprio.

Artigo 65

(Inspecção de Educação)

À Inspecção de Educação cabe o controlo, a fiscalização e a avaliação da Educação, tendo em vista os objectivos estabelecidos na presente lei.

\title{
CAPÍTULO VII \\ Disposições Especiais
}

\author{
Artigo 66 \\ (Acção Social Escolar)
}

O Governo deve promulgar normas especiais sobre o acesso e o usufruto dos serviços sociais escolares.

\section{Artigo 67 \\ (Cidadãos Estrangeiros)}

O Governo define em diploma próprio, os princípios, normas e critérios de frequência dos estudantes estrangeiros nas instituições escolares da República de Angola.

$$
\begin{gathered}
\text { Artigo } 68 \\
\text { (Equiparação e Equivalência de Estudos) }
\end{gathered}
$$

1. Os certificados e diplomas dos níveis Primário, Secundário e Superior concluídos no estrangeiro são válidos na República de Angola desde que sejam reconhecidos pelas estruturas competentes angolanas.

2. As formas e mecanismos de reconhecimento das equivalências são estabelecidos em diploma próprio.

Artigo 69

(Ensino Particular)

1. Às pessoas singulares ou colectivas é concedida a possibilidade de abrirem estabelecimentos de ensino, sob o controlo do Estado nos termos a regulamentar em diplomas próprio.

2. O Estado pode subsidiar estabelecimentos de ensino privado, com ou sem fins lucrativos, desde que sejam de interesse público relevante e estratégico.

3. O Estado define os impostos, taxas e emolumentos a que se obriguem as actividades de educação de carácter privado. 
Artigo 70

(Plano de Desenvolvimento do Sistema Educativo)

O Governo, no prazo de 90 dias, deve elaborar e apresentar para aprovação da Assembléia Nacional, um Plano de Desenvolvimento do Sistema Educativo que assegure a realização faseada da presente lei e demais legislação complementar.

\section{Artigo 71}

(Criação e Encerramento das Escolas)

1. As escolas são criadas, tendo em conta a situação económica e as necessidades sociais do país.

2. As escolas e demais instituições da educação em que haja participação directa de outros Ministérios, são criadas por Decreto Executivo conjunto do Ministro da Educação e Cultura e dos Ministros cuja esfera de acção corresponda aos respectivos ramos e/ou especialidades competindo ao Ministério da Educação e Cultura o papel reitor.

3. As escolas e demais instituições da educação são encerradas, quando deixarem de corresponder aos fins para que foram criadas, por Decreto- Executivo do Ministério da Educação e Cultura e do órgãos de tutela conforme o título de criação.

4. Enquadram-se no Sistema de Educação, as escolas de Instituições Religiosas e de Ensino Militar quando integrada nos Subsistemas, Níveis e Modalidades previstos na lei.

Artigo 72

(Regime de Transição do Sistema de Educação)

O regime de transição do sistema actual para o previsto na presente lei, é objecto de regulamentação pelo Governo, não podendo o pessoal docente, discente e demais quadros afectos à Educação serem prejudicados nos direitos adquiridos.

\section{CAPÍTULO VIII \\ Disposições Finais e Transitórias}

Artigo 73

(Disposições Transitórias)

1. O Governo deve tomar medidas no sentido de dotar, a médio prazo, os ensinos primário, secundário e técnico-profissional com docentes habilitados profissionalmente.

2. O Governo deve elaborar um Plano de Emergência para a construção e recuperação de edifícios escolares e seu apetrechamento, visando ampliar a rede escolar, priorizando o ensino primário. 


\section{Artigo 74 \\ (Regulamentação)}

A presente lei deve ser regulamentada pelo Governo no prazo de 180 dias, contados da data de entrada em vigor.

$$
\text { Artigo } 75
$$

(Dúvidas e Omissões)

As dúvidas e omissões que se suscitarem na interpretação e aplicação da presente lei são resolvidas pela Assembleia Nacional.

$$
\begin{gathered}
\text { Artigo } 76 \\
\text { (Norma Revogatória) }
\end{gathered}
$$

Fica revogada toda a legislação que contrarie o disposto na presente lei.

$$
\begin{gathered}
\text { Artigo } 77 \\
\text { (Entrada em Vigor) }
\end{gathered}
$$

A presente lei entra em vigor à data da sua publicação.

Vista e aprovada pela Assembléia Nacional, em Luanda, aos 13 de Junho de 2001.

O Presidente da Assembléia Nacional

\section{Roberto António Victor Francisco de Almeida}

O Presidente da República

José Eduardo dos Santos 


\section{ANEXO 2: PROGRAMA MÍNIMO DO MPLA}

O MPLA luta pela realização do programa mínimo ${ }^{77}$ seguinte:

Criação urgente de uma Frente Angolana de Libertação que agrupe numa larga união todos os partidos políticos, todas as forças armadas, todas as personalidades eminentes do país, todas as organizações religiosas, todas as etnias, todas as camadas sociais angolanas, todos os angolanos sem distinção de tendências políticas, de condições econômicas, de raça, de sexo ou idade, todos os angolanos residentes no estrangeiro, a fim de realizar os objcetivos seguintes:

a) Continuar a luta POR TODOS OS MEIOS para a liquidação da dominação colonial em Angola, de todos os vestígios de colonialismo ou imperialismo pela independência imediata e completa da Pátria Angola.

b) Defender constante e essencialmente os interesses das massas camponesas e trabalhadores, os dois grupos mais importantes do país, constituindo no conjunto a quase totalidade da população de Angola.

c) Aliar-se a todas as forças progressistas do mundo e conquistar a simpatia e o apoio de todos os povos à causa da libertação do povo angolano.

\footnotetext{
${ }^{77}$ Programa lançado na fase de luta contra o colonialismo português em finais da década de 70 e início de
} 80. In: Angola: Documentos do MPLA. $1^{\circ}$. vol. Série 2 n. ${ }^{\circ}$ 2. ULMEIRO. Lisboa, 1977, p. 63. 


\section{ANEXO 3: PROGRAMA MAIOR DO MPLA}

O MPLA luta pela realização do seguinte programa maior ${ }^{78}$ :

\section{Independência imediata e completa}

$>$ Liquidação, em Angola e por todos os meios, do domínio colonial português e de todos os vestígios de relações coloniais e imperialistas.

$>$ Luta em comum com todas as forças angolanas, num amplo movimento de massas populares, a fim de que o povo angolano conquiste o poder e instaure, em Angola, um regime republicano e democrático na base da independia total.

D Abolição de todos os privilégios que o regime colonial concedeu aos portugueses e aos restantes estrangeiros.

> A soberania do Estado angolano deverá pertencer inteira e unicamente ao povo angolano, sem distinção de etnia, de classe, de sexo, de idade, de tendências políticas, de crenças religiosas e convicções filosóficas.

$>$ A nação angolana terá direito sagrado e inviolável de dispor de si mesma, quer no plano político, econômico, diplomático, militar e cultural, quer em qualquer outro plano.

Devisão da posição de Angola em todos os tratados, acordos e alianças em que Portugal tenha comprometido o país sem o livre consentimento do povo angolano.

$>$ União da vontade popular com o fim de liquidar qualquer tentativa de agressão imperialista e de todos os actos e manobras que visem a independência, a soberania, a unidade e a integridade territorial de Angola.

$>$ Estabelecimento da Paz em Angola, na base da instauração de um regime de justiça social, e na base do reconhecimento, por outros países, da independência, da soberania, da unidade e da integridade territorial de Angola.

\section{Unidade da Nação}

Garantir a igualdade de todas as etnias de Angola e reforçar a união e a ajuda fraterna entre elas.

$>$ Interdição absoluta de todas as tentativas de divisão do povo angolano.

\footnotetext{
${ }^{78}$ In: Angola: Documentos do MPLA. 1. ${ }^{\circ}$ Volume. Série dois n. ${ }^{\circ}$ 2. ULMEIRO: Lisboa, 1977, p.65 - 71.
} 
> Criação de condições para que regressem a Angola e tenham nela uma vida decente as centenas de milhares de angolanos que foram cruelmente obrigados pelo regime colonialista a sair do país.

$>$ Poderão ser autônomas as regiões onde as minorias nacionais vivam em agrupamentos densos e possuam um carácter individualizado.

> No interesse de toda a nação angolana, sustentar e desenvolver a solidariedade econômica e social, bem como relações normais - nos planos econômicos, social e cultural - entre todas as regiões autônomas e de todas as nacionalidades ou etnias de Angola.

Liberdade de circulação de todos os cidadãos angolanos através do território nacional.

\section{Unidade Africana}

Solidariedade total para com todos os povos africanos que lutem pela sua independência completa contra o colonialismo e o imperialismo e, em particular, para com os povos e movimentos políticos que lutem contra o colonialismo português.

Trabalhar pela unidade de todos os povos do continente africano, na base do respeito à liberdade, à igualdade e ao direito ao progresso político, económico e social desses povos.

> União dos povos africanos na base da vontade popular expressa livremente e por meios democráticos e pacíficos.

$>$ Oposição de toda a tentativa de anexação ou de pressão de um povo sobre outro povo.

No processo para a unidade dos povos africanos, defesa das conquistas políticas, econômicas, sociais, culturais das classes trabalhadoras e camponesas de cada país.

\section{Regime Democrático}

$>$ Regime republicano, democrático e laico para Angola.

Garantir a liberdade de expressão, de consciência, de culto; liberdade de imprensa, de reunião, de associação, de residência, de correspondência, etc., para todo o povo angolano. 
$>$ Todo o cidadão angolano - sem distinção de nacionalidade ou etnia, de sexo, de categoria social, de nível cultural, de profissão, de condições de fortuna, de crença religiosa ou convicção filosófica - gozará do direito de eleger a partir dos dezoito anos de idade e do direito de ser eleito a partir dos vinte e um anos de idade.

$>$ Regime eleitoral baseado no sufrágio universal, igual, directo e secreto.

A Assembléia do Povo de Angola será o órgão supremo do poder legislativo do Estado.

> A Assembléia do Povo de Angola sairá de eleições livres gerais. Nas eleições gerais livres, os partidos políticos legais poderão apresentar os seus candidatos com lista comum ou separadamente.

A Assembléia do Povo de Angola elaborará a primeira constituição política da República de Angola.

Todos os membros da Assembléia do Povo de Angola gozarão, efectivamente, de imunidades parlamentares.

$>$ A Assembléia do Povo de Angola designará um governo de coligação que possa e deva reforçar, efectivamente, a união entre as nacionalidades ou etnias, as diferentes regiões do país, as diferentes camadas sociais e os diferentes partidos políticos, e que exprima realmente a vontade da nação em favor da liberdade e do progresso do país e contra a alienação política, económica, territorial ou cultural de Angola a interesses estrangeiros.

O governo da República de Angola receberá o seu poder da Assembléia do Povo de Angola e responderá pela sua política perante esta Assembléia.

O governo da República de Angola será o órgão supremo do poder executivo do Estado.

Cada região autônoma terá o direito de adoptar disposições regionais adaptadas às suas particularidades, mas que não contradigam a legislação geral de Angola.

Africanização dos quadros de todo o aparelho administrativo do país.

Garantia de proteção, de acordo com a declaração Universal dos Direitos do Homem, à pessoa de todos os estrangeiros que respeitem as leis em vigor no país.

\section{Reconstrução econômica e desenvolvimento da produção}

Desenvolvimento por fases e planificação da economia de Angola. 
> Transformação de Angola num país economicamente independente, tendente à liquidação da monocultura, ao aumento progressivo da produtividade agrícola e à mecanização progressiva do trabalho no campo.

Criação e desenvolvimento progressivo de empresas comerciais e industriais do Estado, de cooperativas de compra e venda e das cooperativas de produção. Criação progressiva de industrias para produção de artigos de consumo diário do povo.

$>$ Exploração pelo Estado dos recursos energéticos do país.

$>$ Restauração e desenvolvimento das indústrias tradicionais africanas.

$>$ Abolição dos privilégios atribuídos pelo regime colonial às empresas econômicas portuguesas e às restantes empresas estrangeiras.

$>$ Proteção da indústria e do comércio privados.

Encorajamento da indústria e do comércio privados que sejam úteis à economia do Estado e à vida do povo.

$>$ As empresas econômicas exploradas por estrangeiros deverão conformar-se com as novas leis em vigor em Angola.

Proteção às empresas económicas exploradas por estrangeiros e que sejam úteis à vida, ao progresso e ao reforçamento da independência real do povo angolano.

$>$ Desenvolver e activar fortemente as relações econômicas entre as cidades e o campo no sentido de melhorar progressivamente as condições de vida no campo e o nível de vida das populações camponesas.

$>$ Ampliação efectiva de uma política que considere ao mesmo tempo, os interesses dos empregados e dos patrões.

> Criação do Banco do Estado e da moeda nacional.

$>$ Controlo pelo Estado no interesse do povo inteiro, do comércio externo de Angola.

> Revisão da chamada dívida de Angola para com Portugal. Combate ao déficit da balança comercial de Angola. Equilíbrio das receitas e das despesas do país.

$>$ Abolição do sistema fiscal instituído pelos colonialistas portugueses e criação de um sistema fiscal, racional e simples.

Ajustamento e estabilização dos preços.

Luta contra a especulação com o fim de a liquidar. 


\section{Reforma Agrária}

$>$ Aplicar uma Reforma Agrária que liquide as injustiças existentes em relação à propriedade rural, que liquide o monopólio particular privado da produção de gêneros agrícolas, que contrarie a desnacionalização do solo angolano e que realize o princípio: a terra àqueles que a trabalham.

> Nacionalização das terras dos adversários do movimento popular pela independência imediata e completa de Angola, dos traidores e dos inimigos provados do Estado angolano independente e democrático.

> Definição dos limites da extensão da propriedade privada rural, tendo em conta a situação agrária de a cada localidade.

Após revisão dos títulos de posse das terras, compra pelo Estado, por preço justo, das terras que ultrapassem os limites estabelecidos pela lei.

$>$ Terra para camponeses sem terra e para os que não a possuem suficientemente.

> Os beneficiários das terras legalmente repartidas nada terão a pagar aos expropriados e ao Estado.

Salvaguarda dos direitos conquistados pelos camponeses no decurso da luta popular pela independência de Angola.

\section{Política Social de Justiça e de Progresso}

O estado de verá proteger os direitos dos trabalhadores e dos camponeses, e de todas as camadas sociais que defenderem activamente a independência de Angola, a soberania e a unidade do povo angolano e a integridade territorial do país.

$>$ Abolição imediata do regime de trabalho forçado.

Respeito à independência efectiva dos sindicatos e das organizações legais de trabalhadores.

$>$ Jornada de trabalho de oito horas e a aplicação progressiva de novas leis sobre a protecção do trabalho.

$>$ O Estado fixará o salário mínimo dos trabalhadores e velará pela aplicação rigorosa do principio "salário igual para igual trabalho", sem discriminação de sexo, de idade e de ordem étnica dos trabalhadores.

Protecção das igrejas, dos lugares e dos objetos de culto e das instituições legais. 
$>$ Em todos os planos - político, econômico, sexual e cultural - a mulher terá os mesmos direitos que o homem. As mulheres e os homens serão efectivamente iguais perante a lei.

Assistência do Estado às parturientes e à infância.

Aplicação da assistência social. Assistência a todos os cidadãos angolanos desprovidos de meios e vitimados pela doença, ou em situação de desemprego involuntário ou atingidos pela velhice ou pela invalidez.

D Liquidação progressiva do desemprego. Assegurar trabalho aos operários, empregados, funcionários e aos jovens que completem seus estudos.

Assistência privilegiada a todos os cidadãos em situação de invalidez pela sua participação activa no combate pela independência de Angola. Assistência à família dos que tenham morrido pela liberdade da pátria angolana.

\section{Desenvolvimento da instrução, da cultura e da educação.}

$>$ Liquidação da cultura e da educação colonialista e imperialistas. Reforma do ensino em vigor. Desenvolvimento da instrução, da cultura e da educação ao serviço da liberdade e do progresso pacífico do povo angolano.

$>$ Combate vigoroso e rápido do analfabetismo em todo o país.

$>$ A instrução pública será da competência do Estado e estará sob a sua acção directa.

Tornar efectiva, progressivamente, a instrução primária obrigatória e gratuita.

$>$ Desenvolver o ensino secundário e o ensino técnico-profissional e criar o ensino superior.

Estabelecimento de relações culturais com países estrangeiros. Formação e aperfeiçoamento dos quadros técnicos necessários à construção do país.

> Impulso e desenvolvimento das ciências, das técnicas, das letras e das artes.

$>$ Instrução, no campo, de meios eficazes e suficientes para a assistência médica e sanitária das populações camponesas. Desenvolvimento equilibrado, à escala nacional, dos serviços de assistência médica e sanitária.

$>$ Liquidação da prostituição e do alcoolismo.

Estimulo e apoio às actividades progressistas da juventude.

Fomento e protecção, em todo o país, da cultura física. 


\section{Defesa nacional}

Criação de um exército de defesa nacional, com efectivos suficientes, intimamente ligado ao povo, e comandado inteiramente por cidadãos angolanos.

> Armar, equipar e treinar imediata e devidamente o exército. Instaurar nova instrução militar e política para o exército e unificar essa instrução. Estabelecer relações democráticas entre os oficiais e os soldados. Consolidar a disciplina. No seio do exército, desenvolver e fortalecer uma consciência nacional e combater todas as tendências aos regionalismos.

$>$ Interdição de bases militares estrangeiras no território nacional

\section{Política exterior independente e pacífica}

- Estabelecer e manter relações diplomáticas com todos os países do mundo, na base dos seguintes princípios: respeito mútuo da soberania nacional e da integridade territorial, não-agressão, não-ingerência dos negócios interiores, igualdade e reciprocidade de vantagens, coexistência pacífica.

> Respeito dos princípios da Carta das Nações Unidas.

Não adesão a qualquer bloco militar

Relações especiais de boa vizinhança e de colaboração com as nações limítrofes de Angola.

Protecção dos angolanos residentes no estrangeiro. 


\section{ANEXO 4: MAPA DE ANGOLA - DIVISÃO ADMINISTRATIVA}

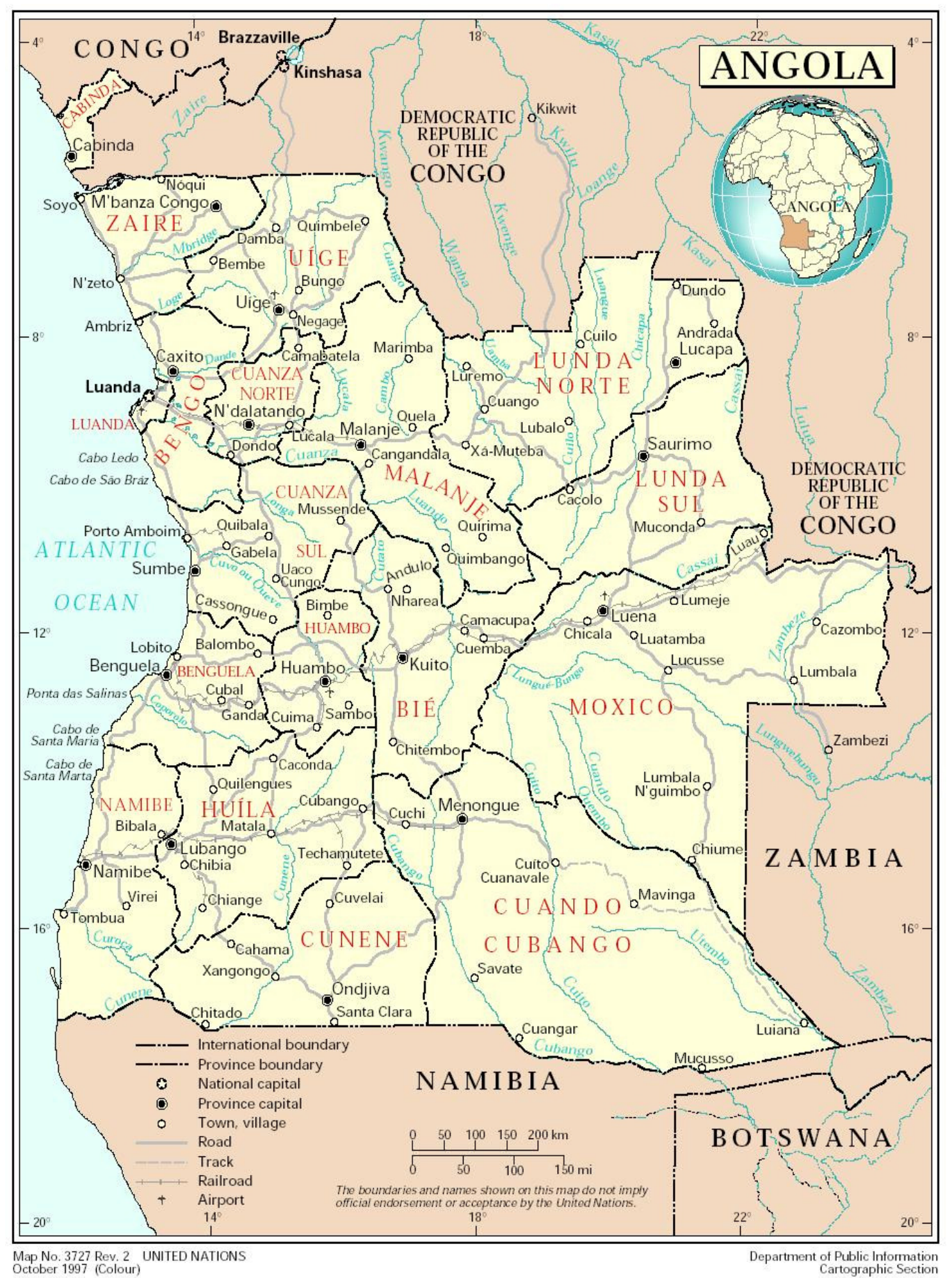

Fonte: http://www.taag.com.br/mapa_angola.htm

Superfície terrestre: $1.246 .700 \mathrm{~km}^{2} ; 1.650 \mathrm{~km}$ de costa e $4.837 \mathrm{~km}$ de fronteira. Temperatura média anual: $27^{\circ} \mathrm{C}$ (máxima) e $17^{\circ} \mathrm{C}$ (mínima). 